University of Rhode Island

DigitalCommons@URI

Open Access Master's Theses

1994

\title{
A STUDY OF U.S. ROUTE 17-92 CORRIDOR, ORANGE CITY, FLORIDA
}

\author{
Edward Pimentel \\ University of Rhode Island
}

Follow this and additional works at: https://digitalcommons.uri.edu/theses

\section{Recommended Citation}

Pimentel, Edward, "A STUDY OF U.S. ROUTE 17-92 CORRIDOR, ORANGE CITY, FLORIDA" (1994). Open Access Master's Theses. Paper 493.

https://digitalcommons.uri.edu/theses/493

This Thesis is brought to you for free and open access by DigitalCommons@URI. It has been accepted for inclusion in Open Access Master's Theses by an authorized administrator of DigitalCommons@URI. For more information, please contact digitalcommons-group@uri.edu. 


\title{
A STUDY OF U.8. ROUTE 17-92 CORRIDOR, ORANGE CITY, FLORIDA
}

\author{
BY \\ EDWARD PIMENTEL \\ A RESEARCH PROJECT SUBMITTED \\ IN \\ PARTIAL FULFILLMENT OF THE REQUIREMENTS \\ FOR THE DEGREE OF MASTER OF \\ COMMUNITY PLANNING \\ UNIVERSITY OF RHODE ISLAND \\ MAY 1994
}


MABTER OF COMMUNITY PLANNING

RESEARCE PROJECT

OF

EDWARD PIMENTEL

APPROVED:

MAJOR PROFESBOR

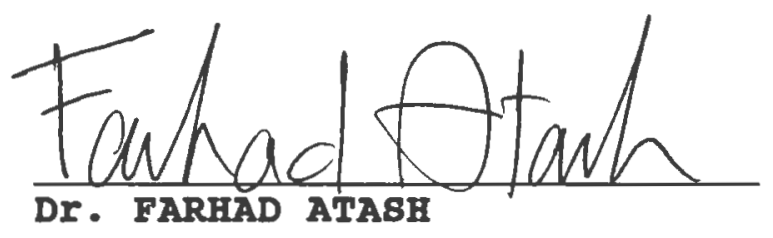

ACRNOWLEDGED:

DIRECTOR

Dr . MARCIA MARKER FELD 


\section{ABSTRACT}

The city of orange City, Florida is located approximately midway between Daytona Beach and orlando, Florida. Therefore, it is directly situated in the mecca of Florida tourism.

orange city has had a long and rich history, including the st, Johns and Blue springs which were the site of more civil War battles than any other locality as well as having contained one of the most nationally renowned natural springs. In fact, Orange city once contained one of the largest orange groves. However, population surges in the City as well as surrounding Communities over the past forty years, has contributed to vast commercial development, and in turn greater automobile usage. This has resulted in increased highway travel, thereby impacting the primary highway traversing orange City, namely Us Route 17-92.

The purpose of this study is to define precisely what the problems were affecting US Route 17-92, and in turn the quality of life in orange city. An assessment of these problems were obtained through various sources, including discussions with orange city and Volusia county staff. However, great insight was acquired from orange City residents and business owners located along US Route 17-92, by means of two surveys. Information was obtained from orange city residents through a telephone survey, and procured from businesses located on US Route 17-92 through a personally hand-delivered survey.

From the findings of the above analysis, the following problems were identified; traffic congestion, high number of accidents, deteriorated city and county streets, unfriendly pedestrian environment and limited pedestrian amenities, as well as an unattractive appearance. The last problem included limited landscaping, vast unbuffered frontage oriented parking lots, haphazard commercial signage and unappealing city signage.

After identifying these problems, the study formulated recommendations using the results of both the resident and business owners surveys. Three categories of recommendations were devised. First, recommendations to reduce the existing highway hazards. Second, recommendations to establish a pedestrian-friendly environment. Lastly, recommendations to address the aesthetics of the project area. 


\section{ACKNOWLEDGEMENT}

In the four months that it took to complete this enormous endeavor, including researching and actual writing, there have been several specific persons who have advised and guided the author. Therefore, the author would like to take this opportunity to thank them for their knowledge, and even more importantly, for their aid in helping the author to complete another chapter in his life, completion of his graduate studies.

The author would initially like to express his sincere thanks to Mr. Milton Moritz, Orange city Public works Director, and $\mathrm{Mr}$. James Kerr, orange City Planning and Zoning coordinator. Both these gentlemen offered numerous insights into the project, and helped to shape the recommendations offered. It would not be incorrect to state that without the intuition of both these gentlemen, this project would not have been possible.

Within the Department of Community Planning and Area Development, there are two persons who deserve the author's sincere thanks. These gentlemen are, Dr. Farhad Atash, and Dr. Howard H. Foster Jr. Dr. Foster was extremely helpful in directing the author down avenues, not readily perceptive. Dr. Atash deserves more thanks than the author is able to express in one paragraph. His guidance, good nature and insightful views were the light that helped this project to shine. To these two gentlemen, the author would like to say with the utmost gratitude, "Thanks for helping a fellow planner receive his Masters in Community Planning".

A special thanks goes to the East Providence Planning Department. There are too many persons, whom the author considers friends, to mention. However, their guidance and insight, as well as support is not forgotten.

Finally, the author must state with deep sincerity and devotion, thanks to his wife, Heidi. Her ever vigilant care and support helped the author in his pursuit of his Masters degree. She deserves a special thank you for her patience, especially during those periods when the computer keys would be clicking away late into the night. 
Abstract

Page

Acknowledgment . . . . . . . . . . . . . . . . . . i i

List of Tables . . . . . . . . . . . . . . . . . v

List of Figures . . . . . . . . . . . . . . . . . . vi

List of Illustrations . . . . . . . . . . . . . . vii

1. Introduction . . . . . . . . . . . . . . . . . . . 1

Study Area Description . . . . . . . . . . . . 1

Problem Statement . . . . . . . . . . . . . 4

Objectives of the study . . . . . . . . . . . . . 6

Significance of the Study . . . . . . . . . . . . 6

Literature Review . . . . . . . . . . . . . . 8

Methodology . . . . . . . . . . . . . . . . . . 9

Organization of the study . . . . . . . . . . . 12

2. Historical overview . . . . . . . . . . . . . . 14

Florida and Volusia County . . . . . . . . . . 14

orange City . . . . . . . . . . . . . . . . 15

US Route 17-92.................. . . 25

3. Existing Conditions . . . . . . . . . . 35

Traffic Analysis . . . . . . . . . . . . . 35

- ADT and Levels of Service . . . . . . . 35

- Public Transportation . . . . . . . . 4 41

- Accidents . . . . . . . . . . . . . 41

- Road Conditions . . . . . . . . . . 50

- Alternative Routes . . . . . . . . . . 54

US Route 17-92 Corridor Analysis. . . . . . . . 56

- Commercial Businesses . . . . . . . . 56

- Building Form, Massing and Architecture . . 59

- Private and Public Signage . . . . . . . 66

- Parking . . . . . . . . . . . . . . 69

- Landscaping . . . . . . . . . . . . . 72

- Pedestrian Amenities and Movement . . . . 74

Blue Springs Park . . . . . . . . . . . . . 75 Summary of Findings . . . . . . . . . . . . 77

4. Resident and Commercial Business surveys . . . . . . 82

Resident survey . . . . . . . . . . . . . . 82

- Survey Methodology . . . . . . . . . 82 
- Survey Results . . . . . . . . . . . 84

- Significance of the Survey . . . . . . . 90 Commercial Business Survey . . . . . . . . . . 97

- Survey Methodology . . . . . . . . . . 97

- Survey Results . . . . . . . . . . . . . 98

- Significance of the Survey . . . . . . 105

5. Recommendations . . . . . . . . . . . . . . . 114

Traffic Congestion . . . . . . . . . . . . 115

Accidents . . . . . . . . . . . . . . . 118

Road Conditions . . . . . . . . . . . . 125

Pedestrian Environment . . . . . . . . . . . 128

Pedestrian Amenities . . . . . . . . . . . . 141

Commercial Signage . . . . . . . . . . . . . . 144

City Entrances (Gateways) . . . . . . . . . . 146

Parking . . . . . . . . . . . . . . . . . . . . 149

Landscaping . . . . . . . . . . . . . . . . . . 150

street Lighting and Electrical wiring . . . . . 152

6. Implementation strategies . . . . . . . . . . 156

Administrative Strategies . . . . . . . . 156

- Traffic Oriented . . . . . . . . . 156

- Amenities . . . . . . . . . . . . 158

- Pedestrian Concerns . . . . . . . . 159

- Aesthetics . . . . . . . . . . . . 159

Funding Sources . . . . . . . . . . . . . 160

- Federal ................ 160

- State of Florida... . . . . . . . . 161

- orange City .................. 162

Regulatory strategies . . . . . . . . . . 163

Appendix

References 


\section{LIBT OF TABLES}

Table

Number

Chapter

3.1

4.1

4.2

5.1

5.2

$5 \cdot 3$

5.4

\section{Appendix}

A. 1

A. 2

A. 3

A. 4

A. 5

A. 6

A. 7

A. 8

A. 9

A. 10

A. 11
Title

Page

Number

Accidents and Resulting Injuries:

1987 - 1992 (Summary Table)

96

110

129

131

133

137

Phase IV - Road Repair Recommendations

Business Owners' Additional Comments

Phase I - Road Repair Recommendations

Phase II - Road Repair Recommendations

13

Phase III - Road Repair Recommendations

37

6

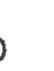




\section{LIBT OF FIGUREB}

Figure

Number
Title

Page

Number

1.1 Orange City Locus Map 2

1.2 Map Illustrating the Project Area 3

1.3 Orange City Land-Use Map 5

2.1 C.E. Trafford's Original Parcel Map 17

2.2 Austin Wilson \& Co's Map of Orange City - 188320

2.3 Orange City, Florida 24

2.4 Orange City and Volusia county Population: 1885 - 1992

Intersections Which Have Been the scene of Numerous Accidents

US Route 17-92 Existing width Configuration

51

US Route 17-92 Proposed Reconfiguration

Streets Requiring Repairs

Proposed West Volusia Beltline

5.1

Cross-Sectional View of the Proposed Islands

123

$5 \cdot 2$

Visual Representation of streets Being Recommended for one-Way Status

126

130

Phase I - Road Repair Recommendations

132

Phase II - Road Repair Recommendations

136

Phase III - Road Repair Recommendations

139

Phase IV - Road Repair Recommendations

148 


\section{LI8T OF ILLUSTRATIONB (PHOTOGRAPH8)}

Ilustration

Number
Title

Page Number

2.2

2.3

2.4

$2 \cdot 5$

2.6

$2 \cdot 7$

$3 \cdot 1$

3.2

3.3

3.4

3.5

3.6

3.7

3.8

3.9

3.10

3.11

The F.E.C. Depot and "Old Faithful"

Present Site of the Water Works Co.

Photograph taken in the $1880 \mathrm{~s}$

Turn of the Century Photograph of

US Route 17-92

Utilizing Prisoners "Chain Gang" for Road Construction

Placement of Telephone Poles and Electrical

Lines in orange city

Photograph of US Route 17-92 as it Appears Today

Daily Traffic on US Route 17-92

Photographs of the Primary US Route 17-92

Intersecting Roads

Original Appearance of the Webster Medical clinic

Hasit House as it Appears Today

61

The Former Deyarman Hotel as it Appears Today

62

The Emily Dickerson Library as it Appears Today 63

The Midas Shop Fabricated of Tin

Carl and Bob's Auto Repair - Repairs Done outdoors

Scotty's Vast Frontage oriented Parking Lot

Orange City Town Hall, Located on

East Graves Avenue

Typical Pole and Wall sign Located Along US Route 17-92

19

21

26

28

29

30

\section{4}

3




$\begin{array}{lll}3.12 & \begin{array}{l}\text { One of Several Billboards Located on } \\ \text { US Route 17-92 }\end{array} & 69 \\ 3.13 & \begin{array}{l}\text { Limited Example of a Well Landscaped } \\ \text { Commercial Sign }\end{array} & 70 \\ 3.14 & \text { Example of a Small, yet Informing Sign } \\ 3.15 & \text { The Northerly Entrance Sign to orange City } \\ 3.16 & \begin{array}{l}\text { Example of a Large Parking Lot Along } \\ \text { US Route 17-92 }\end{array} \\ 3.17 & \begin{array}{l}\text { Example of a Pedestrian Attempting } \\ \text { to Cross Us Route 17-92 }\end{array} \\ 3.18 & \text { Primary Features of Blue Springs Park }\end{array}$




\section{Chapter one - Introduction}

The city of orange city is located on the east coast in central Florida, approximately midway between Daytona Beach and Orlando, Florida (Figure 1.1). The primary routes which traverse orange City are I-4 (east-west) and US 17-92 (northsouth). Orange City is approximately 6.25 square miles in size ${ }^{1}$ and its population in 1992 was 5,7342. Though the City exhibits a small-town atmosphere, it does contain an extremely urbanized appearance along its US Route 17-92 Corridor. US Route 17-92, originally referred to as the "Black Bear Trail" 3 , owes its existence to the early settlers who developed it when travelling by wagon and utilizing it for the shipment of cattle. Today, US Route $17-92$ is a principal arterial highway ${ }^{4}$ which is heavily traveled and extremely commercialized.

\section{BTODY AREA DESCRIPTION}

This report will analyze that section of US Route 17-92 which traverses Orange city (also referred to as Volusia Avenue), and sections of Volusia county $y^{5}$ in Florida. The length of the project area is approximately 3 miles, from Wisconsin Avenue to Enterprise Road (Figure 1.2). The project area's boundaries are as follows; Wisconsin Avenue to the north, Sparkman Avenue to the west, intersection of US Route 17-92 and Enterprise Road to the south, and Leavitt Avenue to the east. In addition, Enterprise Road will be discussed, due to the commercial malls which are located along its stretches 
FIGURE 1.1 - ORANGE CITY LOCUS MAP

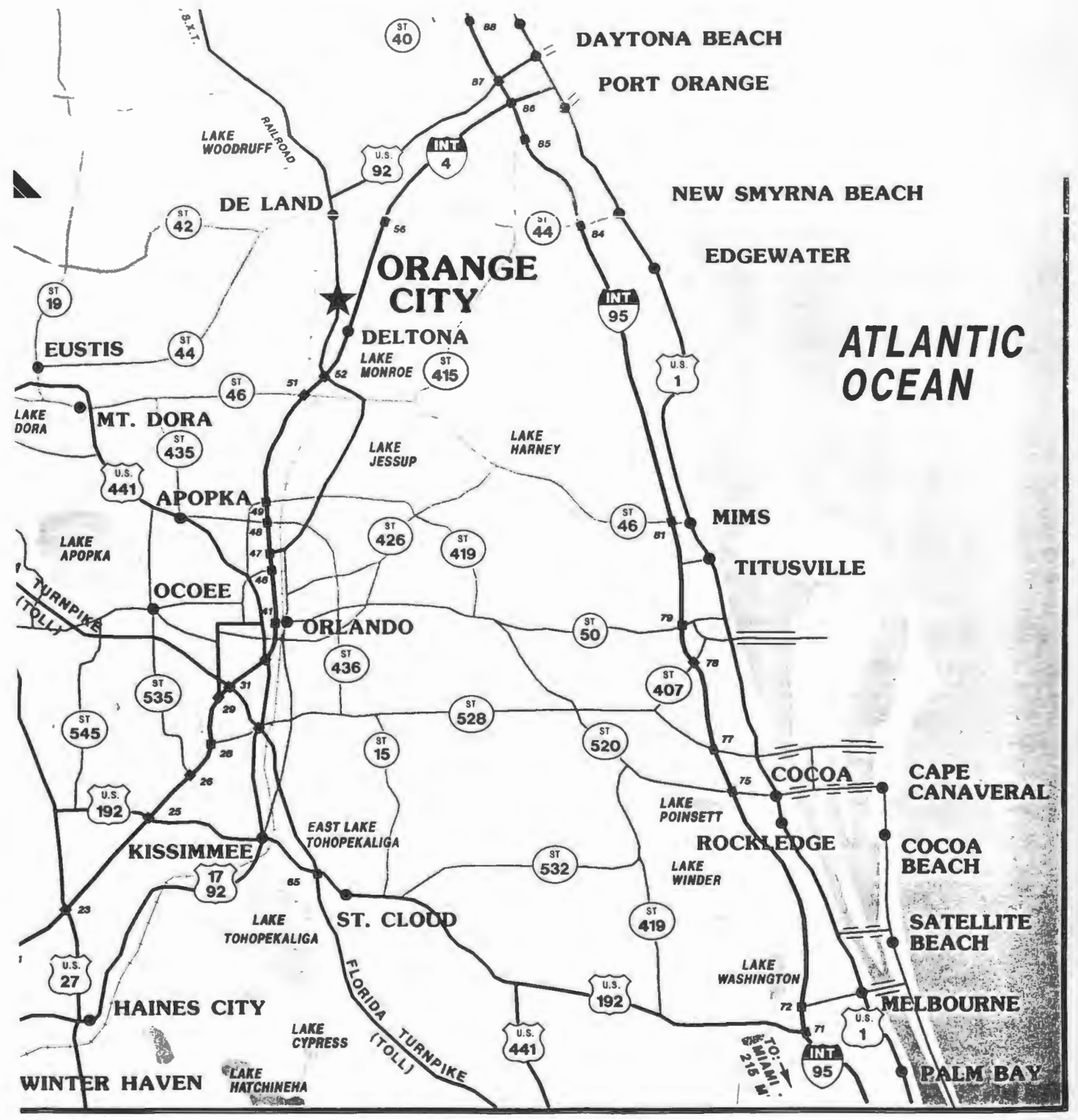

(Source: Mosher-Adams, Inc, Map of Orange City, Florida, 1993) 


\section{FIGURE 1.2 - MAP ILIUSTRATING THE PROJECT AREA}

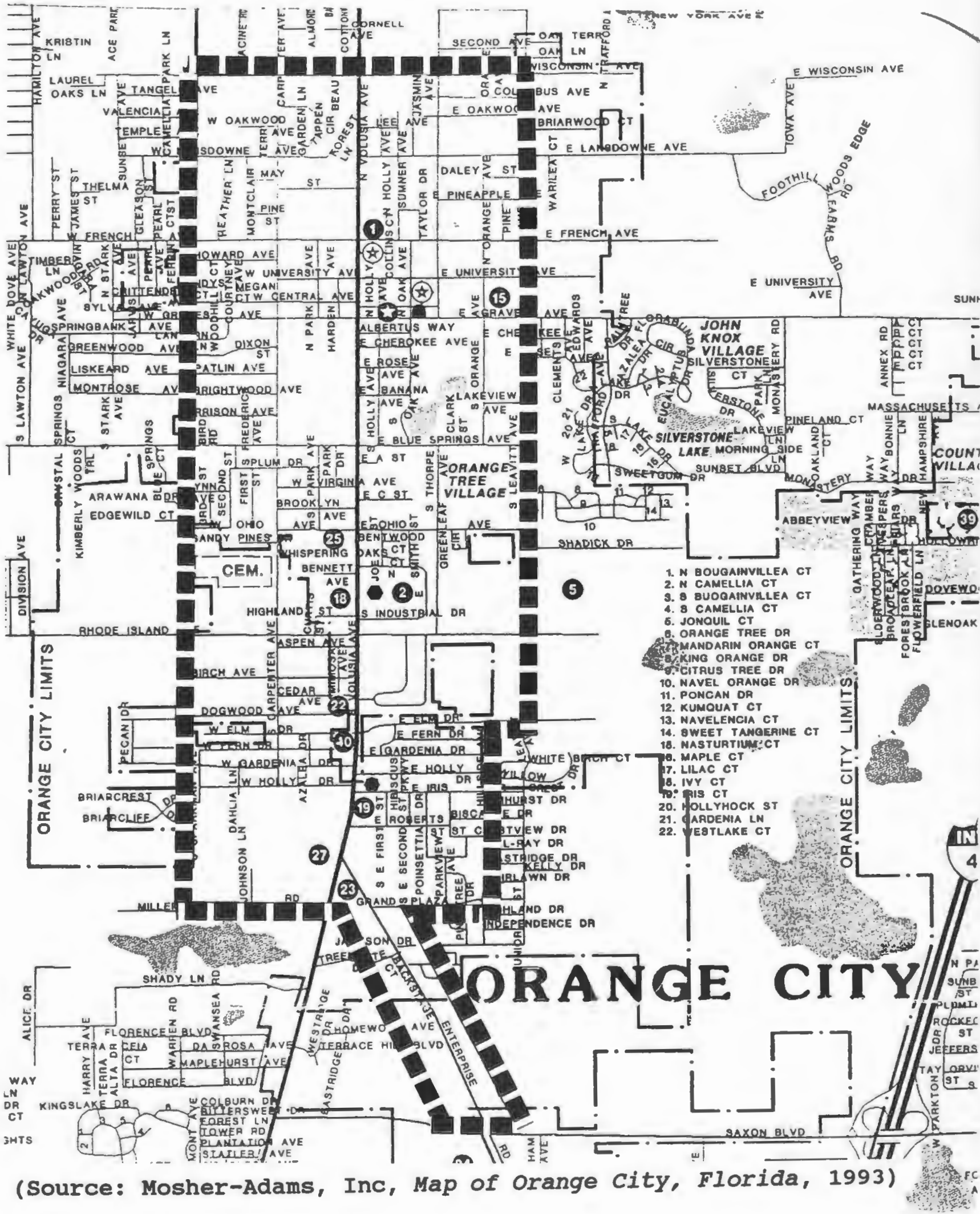


and their contribution to the traffic concerns along US Route 17-92. The land-use which immediately surrounds Us Route 1792, and primarily all of the project area, is commercial General (CG). There are several other land-uses encompassing the project area, but only to a small degree. These include, Commercial Intense, Mixed-Use, Institutional, officeTransitional, and a variety of residential uses located on the outer fringes of the project area (Figure 1.3).

\section{PROBLEM STATEMENT}

US Route 17-92 has become so over burdened by automobile usage that the issues of congestion and safety are very real concerns. US Route 17-92 is currently handling between 35,000 and 40,000 vehicles a day which categorizes it as a service Level F, or in other words, backlogged. ${ }^{6}$ As a result of the auto-oriented nature of the area, pedestrian movement has become hindered, thereby, making it unsafe. Furthermore, the aesthetic appearance of the roadway and surrounding commercial businesses have diminished, thereby, affecting the pleasant rural character of the area. Concerns such as signage, vast areas of street side paved parking, limited usage of landscaping material and few pedestrian amenities are just some of the factors which will be analyzed. 


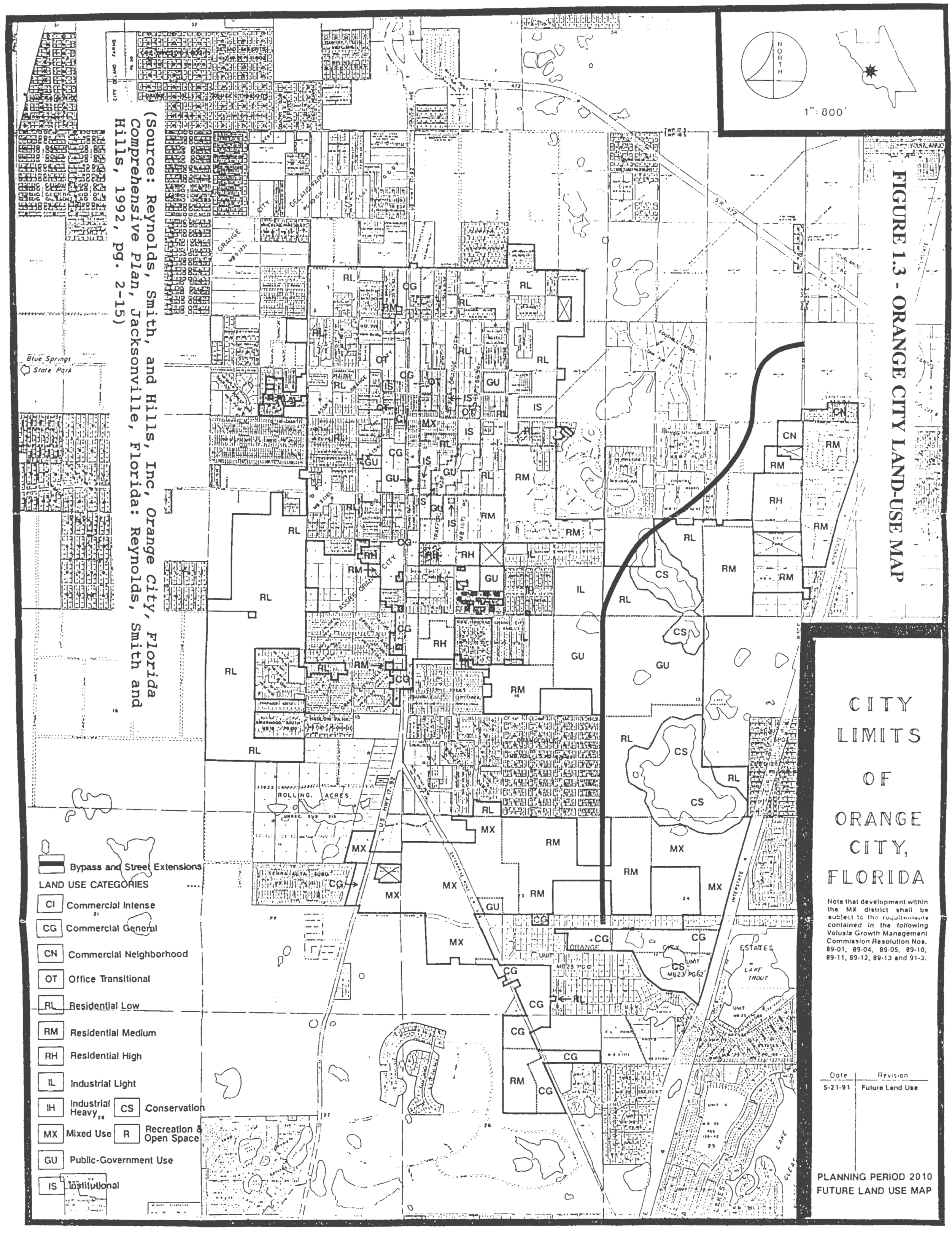




\section{OBJECTIVES OF THE STUDY}

- Objective 1: Assess the perceptions of citizens/consumers and commercial business owners residing within the project area in regards to existing conditions along US Route 17-92.

- Objective 2: Analyze and assess methods of addressing existing traffic and pedestrian concerns.

2a: Reduce congestion and improve Level of Service

2b: Eliminate accident prone points

2c: Create a more pedestrian environment by reducing existing traffic hazards

2d: Establish a variety of pedestrian amenities

2e: Improve existing road conditions for safety as well as cost efficient reasons

- objective 3 - Endorse recommendations which will screen the existing bleak appearance of US Route 1792, thereby, establishing a more conducive atmosphere for both pedestrian and vehicular movement.

3a: Control haphazard signage growth

3b: Improve the aesthetic appearance of commercial parking areas

3c: Utilize the application of appropriate landscaping materials to soften the hard urbanized features of the area

3d: Enhance the gateway appearance of US Route 17 -92 in order to offer a positive first impression to all who enter orange city

\section{BIGNIFICANCE OF THE STUDY}

US Route 17-92 is both the primary transportation corridor as well as the northern and southern introductory gateway for orange City, Florida. It is therefore, imperative that this corridor offer the foremost impression to all who traverse orange city. The corridor's aesthetic appearance must be enhanced. Furthermore, it is essential that US Route 17-92 be redesigned in such a way as to improve existing traffic volumes (thereby upgrading the current Level of 
Service) while simultaneously enhancing pedestrian movement in a safe and pleasing manner.

The primary purpose of this study is to aid in halting a process which has been slowly decaying a once attractive and small-town like atmosphere. Furthermore, the city of orange city, Florida, recommended conducting such a study and offered help and assistance as needed throughout this study. Recently, the Florida Department of Transportation proposed to widen that section of US Route 17-92 which traverses orange City, from a four-lane to a six-lane highway. Extensive opposition defeated this proposal. This then led to a second proposal by the Department of Transportation, namely to remove the on-street parking lanes and incorporating them into the existing traffic lane configuration. Should this second proposal be accepted, the existing traffic congestion will be somewhat mitigated. However, residents and business owners are not so sure that this will occur. The fear is that increasing the width of the lanes will lead to additional speeding and not the elimination of existing traffic volumes. Furthermore, widening the existing lanes does not address the needs of pedestrians and their inability to cross us 17-92 in a safe manner. An additional reason for stressing the importance of this study is in regards to the safety concerns which have been voiced. Specifically, the escalating number of automobile accidents ${ }^{7}$ at specific points due to the 
hazardous middle left-hand turn lane and increasing traffic volumes along US Route 17-92.

\section{LITERATURE REVIEW}

The literature which has been reviewed as a part of this study consisted primarily of Planning Advisory Service Reports (PAS). The reason for relying so heavily upon PAS Reports was due to their significance in outlining and proposing conceptual recommendations towards alleviating the numerous problems which exist along US Route 17-92. Areas such as traffic congestion and escalating automobile accidents, reducing obstacles which impair pedestrian movement, signage control, screening harsh edges through appropriate landscaping, buffering vast frontage oriented parking lots, as well as stipulations requiring and monitoring the placement of pedestrian amenities, are well discussed within the PAS Reports.

Through contact with the Planning Advisory Service Research office in Chicago, Illinois, several case studies were procured which are similar in nature to the investigation at hand. Three of the case studies offered guidance on how to enhance a community's gateway and utilize such an entrance to promote specific points of interest within the community. These case studies were; a 1984 entrance beautification study for the city of Eugene, Oregon, a 1984 analysis of small town entrances by Tim Hansen, and a 1992 design entryway corridor 
plan for Bozeman, Montana. The remaining case studies discussed the specifics of redesigning a commercialized highway corridor. The information contained within these documents actually outline an action plan towards improving and redesigning the highway commercial corridor under study. These studies are as follows:

- Bond street Corridor Redevelopment strategy \& Streetscape Improvement Plan. Bel Air, Maryland. 1991.

- Brookpark Road Corridor study. Cleveland, Ohio. 1988.

- Grand/Main Corridor Study. Kansas City, Missouri. 1987.

- Independence Avenue Corridor Plan. Kansas City, Missouri. 1993.

- University Avenue Corridor Plan. Las Cruces, New Mexico. 1991.

- U.S. Highway 41 Corridor Study: Inventory and Analysis. Bradenton, Florida. 1992.

- Ward Parkway Corridor study. Kansas City, Missouri. 1990 .

The "Bond street Corridor Plan" for Bel Air, Maryland was important literature because its physical makeup paralleled US Route 17-92, and contained the same types of problems.

\section{METHODOLOGY}

This section will outline the methodology used to achieve each objective. 
Objective 1 - The first step in realizing a successful research project will involve conducting surveys of businesses (only those located within the project area along US Route 1792) and orange city residents. The surveys were constructed by consulting several of the previously mentioned case studies. Several of the questions which specifically addressed aesthetics, were a compilation of questions utilized throughout previously conducted surveys. The remaining questions, those addressing traffic considerations as well as two which addressed aesthetics, were constructed from discussions with Milton Moritz (Orange City Director of Public Works) and James Kerr (Orange City Planning and Zoning Coordinator). The business survey was hand delivered to each individual business. This allowed the owners to answer them at their convenience. On the other hand, the resident survey was conducted by telephone. The reason for this is due to the tremendous amount of time and teamwork required to successfully accomplish an in-person style survey. A mail questionnaire was likewise avoided for the same reasons. Furthermore, discussion with the orange city Planning Department resulted in a concurring opinion that administering the survey through local businesses, (leaving survey forms at selected businesses to be filled out by customers as they visit these establishments) would also fail to furnish the necessary response rate.

The two surveys consisted primarily of close-ended, 
"yes and no" type questions. The purpose for organizing the surveys in this manner, was to target specific problem areas as well as reduce administering time. In order to ensure that the data collected was a true representation of all orange City residents, an attempt was made to survey 244 households, or 10\% of the 2,440 total households in Orange City. ${ }^{8}$ Such a response rate would assure that at minimum a $90 \%$ confidence interval was achieved." However, due to time constraints, lack of citizen participation and inability to successfully reach residents at home, only 176 households were contacted.

objective 2 - The survey data was used to assess traffic concerns from a user's perspective. However, a true appraisal of the existing traffic problems was derived from analyzing records of the Volusia County Department of Transportation. These records precisely enumerated accident prone areas and identified the existing Levels of Service, thereby, indicating areas of congestion. This information helped to assist in targeting those areas which need redesigning (e.g. accident prone intersections). Finally, consulting with Mr. Milton Moritz, orange city Director of Public Works helped to identify recommendations which are feasible.

correction of existing traffic problems and hazards will aid in reestablishing pedestrian movement throughout the study area. The resident survey helped to determine the perception of city residents towards existing conditions along us Route 
17-92, thereby, helping in the redesigning of a more pedestrian oriented corridor. Determining and designating which pedestrian amenities are lacking stemmed from discussion with orange city staff and the data gathered from the two surveys.

objective 3 - All urban design considerations, (signage, parking lot screening, buffering harsh edges and corridor entrances) were addressed once all the data were collected. Such data included; resident and business surveys, traffic analysis, analysis of existing conditions, discussions with Orange city staff and consulting Volusia County personnel as required. This information was then cross-referenced by PAS Reports and similar case studies.

\section{ORGANIZATION OF THE BTUDY}

This study is divided into six chapters. Following this introduction, chapter Two provides a historical overview of Orange city and the project area. Chapter Three analyzes the existing conditions of the project area. Chapter Four describes the results of the resident and commercial business surveys. Chapter Five presents alternative recommendations for the project area. Lastly, chapter six identifies alternative strategies to implement the proposed recommendations. 
${ }^{1} \mathrm{Mr}$. James Kerr, Orange City Planning and Zoning Coordinator, interview by author, 7 February 1994, Orange City, Florida, oral, orange city Town Hall, orange city, Florida.

${ }^{2}$ Bureau of Economic and Business Research, College of Business Administration, "Florida Estimates of Population April 1, 1992" (Gainesville, Florida: University of Florida, 1993), 26, photocopied.

${ }^{3} \mathrm{Village}$ Improvement Association, Our story of Orange City, Florida (DeLand, Florida: Carter Printing Co., 1975), 29 .

$$
\begin{aligned}
& \text { 4Orange City, Florida, Orange City Comprehensive Plan, } \\
& \text { (1992) 3-2. }
\end{aligned}
$$

5orange City is constantly expanding in size due to the annexation of sites from Volusia County. However, there are several properties along US Route 17-92 which are still located within Volusia county. Therefore, an accurate assessment of conditions along US Route 17-92 will require researching both areas.

${ }^{6} \mathrm{Bill}$ Linkovich, "Volusia County Roadway Report," (DeLand, Florida: Department of Transportation, 1993) Computer Printout.

${ }^{7}$ The years 1987 - 1992 had a total of 376 reported accidents and a resulting 472 injuries. (Bill Linkovich, "Crash Detail Reports from 1987 - 1992," DeLand, Florida: Department of Transportation, 1987-1992. Computer Printout). This however, is not an accurate assessment, because less than $50 \%$ of all accidents are reported due to the Florida no-fault insurance law and the increase in insurance rates once they are reported. (Mr. Milton Moritz, Orange City Director of Public Works, interview by author, 7 February 1994, orange City, Florida, oral, orange City Town Hall, orange City, Florida.)

${ }^{8} 1990$ Census of Population and Housing, Summary Tape File 3A, DeLand, Florida: Stetson University, 1990.

9Therese Houten and Harry P. Hatry, "How to conduct a Citizen Survey," Planning Advisory Service Report, no. 404 $(1987): 9$. 
This chapter briefly explores the rich history of Volusia County and orange city. Furthermore, it includes a historical examination of US Route 17-92. This investigation describes how and when US Route 17-92 was first established and how it has changed over the last one hundred and thirty years.

\section{FLORIDA AND VOLUSIA COUNTY}

The story of Orange city begins with the introduction of America's forefathers, namely the Native Americans. Florida's Indian population in the mid-1500s can be broadly categorized as follows:

"Principal among them were the Timucuans with 14,300, including some 1,300 Tocobega at Tampa, sometimes named separately; the Calusa, 2,375 including 550 Mayaimi in the Lake Okeechobee region; the Ais, including the Jeaga, 800; the Apalachee, 6,800 including 500 Chatot, 800 Apalachicola, and 300 Pensacola; and 800 Tequesta."

The Seminoles, who were primarily a mixture of creek and African American, did not appear in Florida till the mid1800s. The St. Johns River, located just west of orange City and US Route 17-92, has been the site of numerous excavations. This site has verified that the predominant Indian civilization to flourish in the area belongs to the Timucuan tribe. However, by the early $1800^{\prime} \mathrm{s}$, the Creeks (which later gave way to the Seminoles), had all but decimated the Timucuan tribe. ${ }^{2}$ 
The Europeans had already explored various aspects of the South American continent as well as the Caribbean, however, they did not officially land on modern day Florida till the early 16th century. The first person to be officially recognized as accomplishing this historical visit is Juan Ponce de Leon in the year 1513. Numerous visits were soon made by other countries such as spain, England, and France. Their intent was fortune, not colonization, and it soon became clear to all that Florida was strategically a good location to position military forces. Thereby establishing the early history of Florida as a place of strategic importance and conquest.

The decades saw conflict after conflict between the Indians and European settlers. In the area of Enterprise near Green Springs (a section of Volusia county located just southeast of orange (ity), the Great second Seminole war occurred. ${ }^{3}$ This was one of the last great stands offered by the Indians, in the Central Florida area. Florida's long fought Indian wars were basically over by the mid-1800s. With the end of the turmoil came prosperity, and admittance into the Union on $\operatorname{March} 3,1845$.

\section{ORANGE CITY}

The story of orange city begins with the arrival of Louis P. Thursby, a confederate sympathizer who made his way down the st. Johns River and built a home along Blue springs (site 
of Blue spring state Park in modern day orange City). He settled specifically in this area because of its central location and the ability to control the entire st. Johns. ${ }^{4}$ Florida was in fact the confederate army's breadbasket, and thus, control of each and every waterway was imperative. An item of interest, and one that is not too well known, is the fact that the st. Johns saw more battles than any other area during the Civil War. Louis P. Thursby, is thus credited as being the first permanent resident of the area. Orange City's true founders however, would not appear till after the civil War had ended.

The residents of Eau Claire, wisconsin were wealthy lumbermen who fought during the war in the area now known as Volusia county. In the $1870^{\prime} \mathrm{s}$, a conflagration destroyed a large section of the Town of Eau claire as well as its main source of labor and income, the local lumber company. As a result of this incident, the wealthy lumber company owners relocated to the area (present day orange city) with which they had become acquainted during the war. They formed the "wisconsin Company" (which was comprised of six men: Dr. Seth French, J.C. Stillman, william Hawley, J.C. Thorpe, Charles Smith, and Mr. Cameron) and leased a large tract of land from the Florida Improvement Fund, an "internal improvement program"5. The area purchased measured approximately 1,026 acres, or 5 square miles. The land, once purchased, was cleared and partitioned off for sale. 
A fellow Eau Claire resident by the name of H.H. Deyarman was also interested in the area. Mr. Deyarman had acquired his wealth in the hotel business, and wished to expand this industry into present day orange City. He made a deal with the Wisconsin Company and opened up Volusia county's first hotel, which is located today along Us Route 17-92 within the study area.

The Wisconsin Company hired the services of C.E. Trafford, a neighboring surveyor, to survey and construct a parcel map of the City (see Figure 2.1).

Figure 2.1

C.E. Trafford's Original Parcel Map

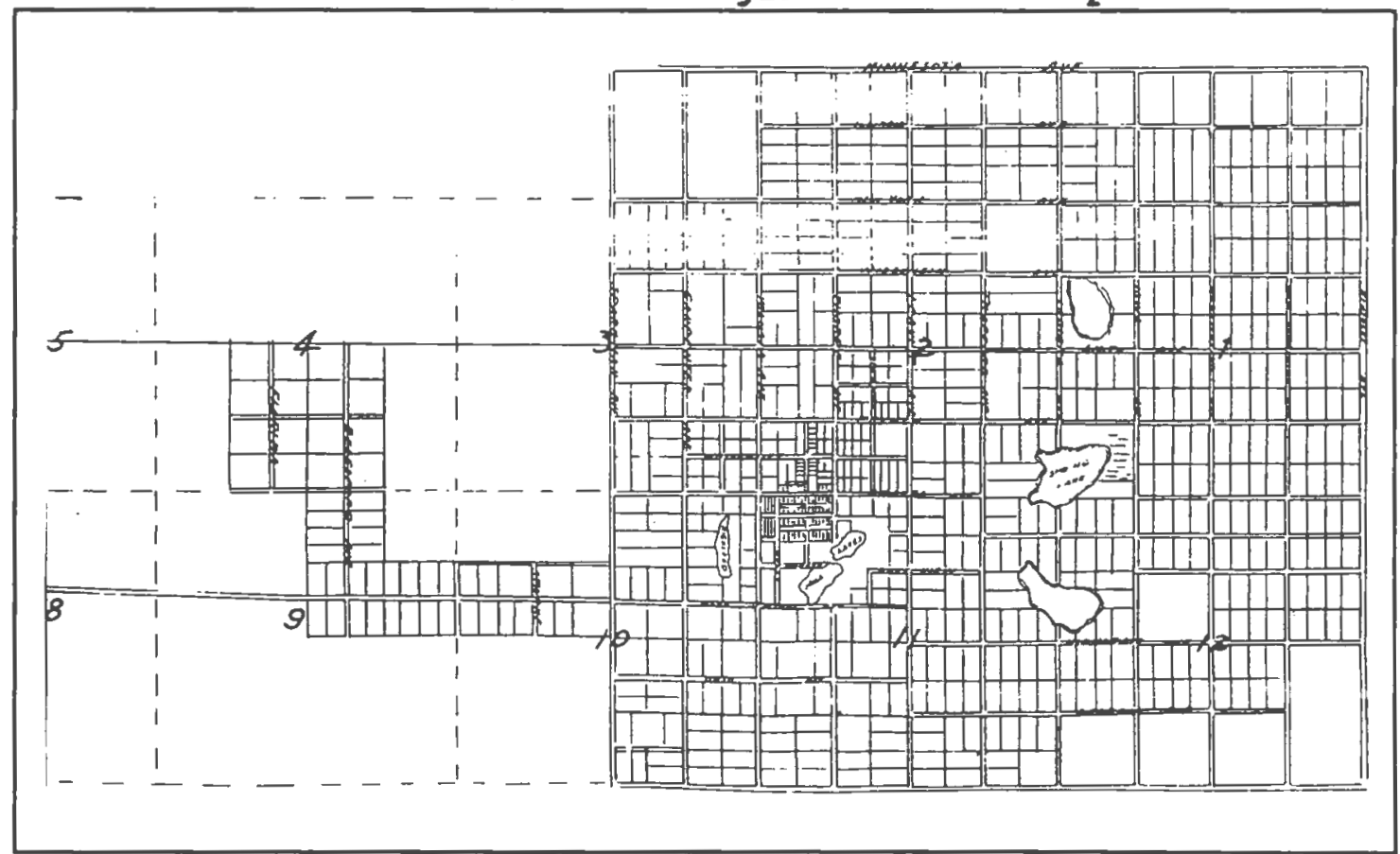

(Source: James Kerr, Orange City Planning and Zoning Coordinator, orange City, Florida)

Once surveyed, members of the Wisconsin company formed the orange city Immigration society. The duty of this society 
was to entice fellow wisconsin's, as well as others, to relocate to the area. ${ }^{6}$ The Immigration Society was also instrumental in forging the decision to incorporate it into a city. There was discussion over whether the area should be named Blue Springs, (after the nearby natural spring) or orange City. A Democratic style vote settled the dispute in favor of "Orange city", which was rather ironic since there were no oranges to be found in the area at that time. The 1870 s and 1880s, however, saw the area transformed into a vast citrus grove (predominantly comprised of oranges), which became its main income producer.

In 1881 , W.W. West laid down the first railroad tracks in Volusia county (IIlustration 2.1). It started in the center of town on Graves Avenue and proceeded two miles west ending at Blue springs. The railway was driven by mule at first, but steam power eventually took over. It was predominantly used for transporting oranges to the steamers that sailed the st. Johns, though, it also occasionally carried prospective orange City residents. ${ }^{7}$ The tracks were located upon the only real road in existence at that time. C.E. Trafford had included right of ways in his original survey, but these would not become existing roads for many decades to come. The following year, 1882, the city was incorporated.

The population of orange city had increased from a mere dozen individuals in the early 1870 s to "800 in 1885". The 
size of the City was also impacted, as it increased to 11.8 square miles (Figure 2.2).

\section{Illustration 2.1}

"The F.E.C. Depot and "old Faithful"

Northwest corner of Volusia and W. Graves Aves.

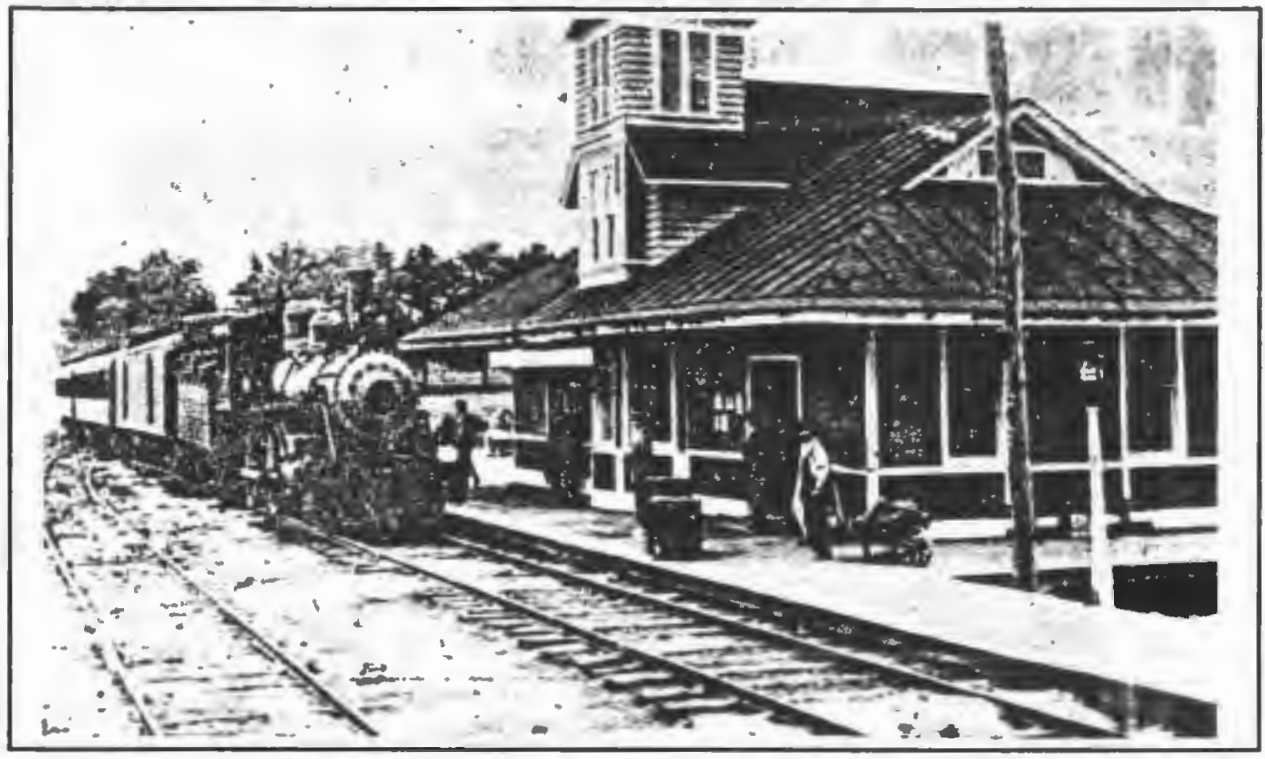

(Source: Village Improvement Association, Our story of Orange City, Florida (Deland, Florida: Carter Printing Co., 1975), 67)

This vast growth was solely as a result of its successful orange industry. However, there were two problems associated with this industry that needed to be resolved. The first problem was the type of soil that existed in the area. The soil was of such a light consistency (much like beach sand) that water was rapidly absorbed, thereby, never allowing enough moisture to settle at the base of the orange trees.' A solution to this problem was proposed by H.H. Deyarman, who realized that there was a serious need for some sort of irrigation system. H.H. Deyarman contacted C. A. Bullen in Eau Claire, Wisconsin. Mr. Bullen was the owner of the local 
Figure 2.2

Austin Wilson C Co's Map of Orange City - 1883

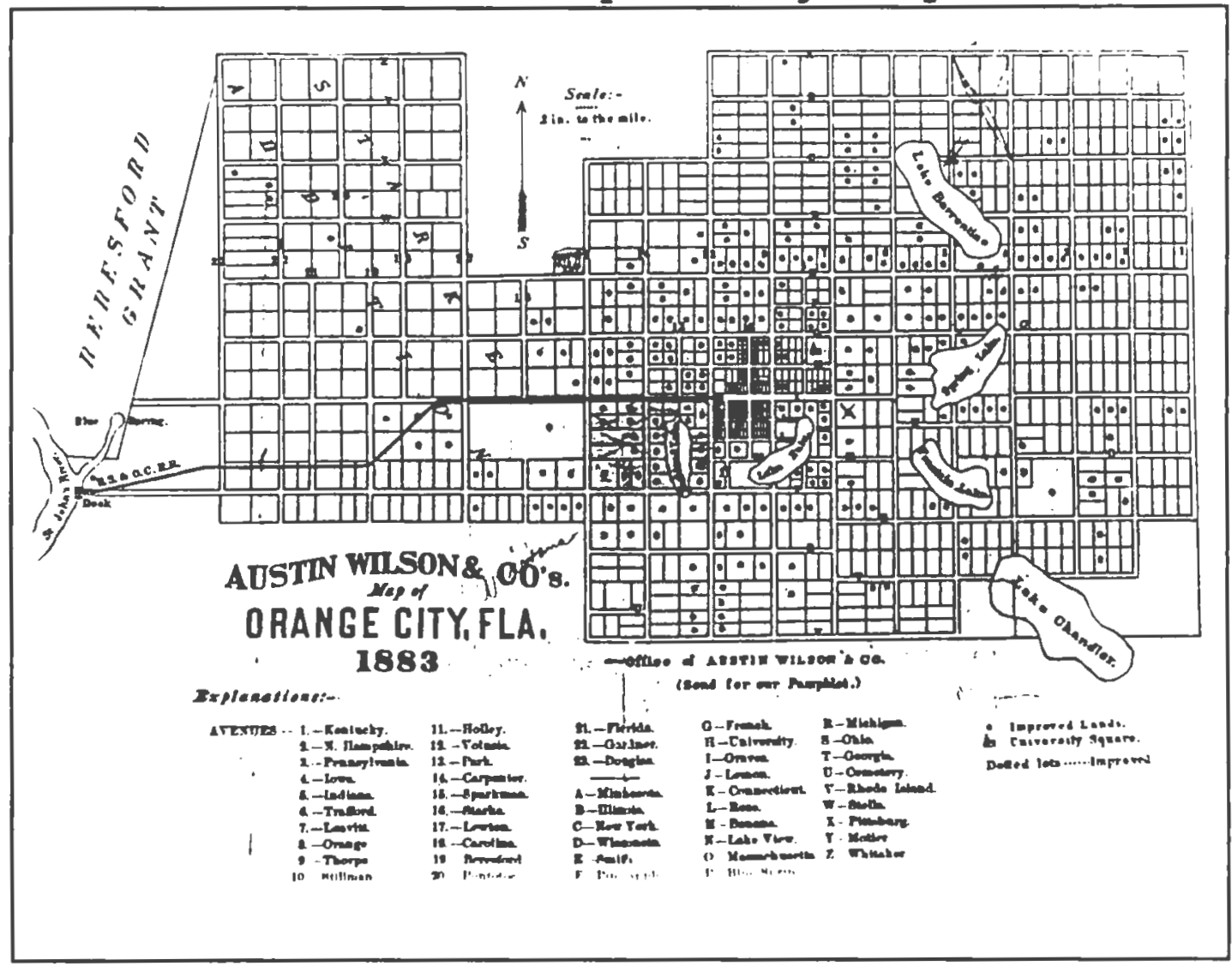

(Source: Bill Dreggors, West Volusia Historical Society)

water company in Eau Claire, and therefore, had vast experience in irrigation systems. Mr. Bullen relocated to orange city and purchased a plot of land for the purpose of tapping into the spring. Once tapped, the water gushed forth with such intensity that it seemed inexhaustible, and it was upon this land that he built his new water Works Company. ${ }^{10}$ The final step involved connecting the spring to all orange city residents. The pipes required to complete this task were predominantly forged in the north, and therefore, a request was made to have a shipment delivered. However, the 
ship which carried the cargo accidently sank in passage, thereby, postponing the long awaited irrigation system. A second shipment was requested and delivered and on February 8 , 1895, the Orange City Waterworks Company began pumping water at the rate of 67,000 gallons per hour. ${ }^{11}$

"Later a large storage tank was built in Block 22 on Volusia Avenue just north of French Avenue. This tank was twenty feet high and was supported eighty feet in the air on an iron frame. In 1930 this was replaced by the storage tank on Block 8 at the site of the present water works."12 (see Illustration 2.2)

Illustration 2.2

Present site of the water Works co.

Located between Banana Avenue and Blue Springs Avenue, along US Route 17-92

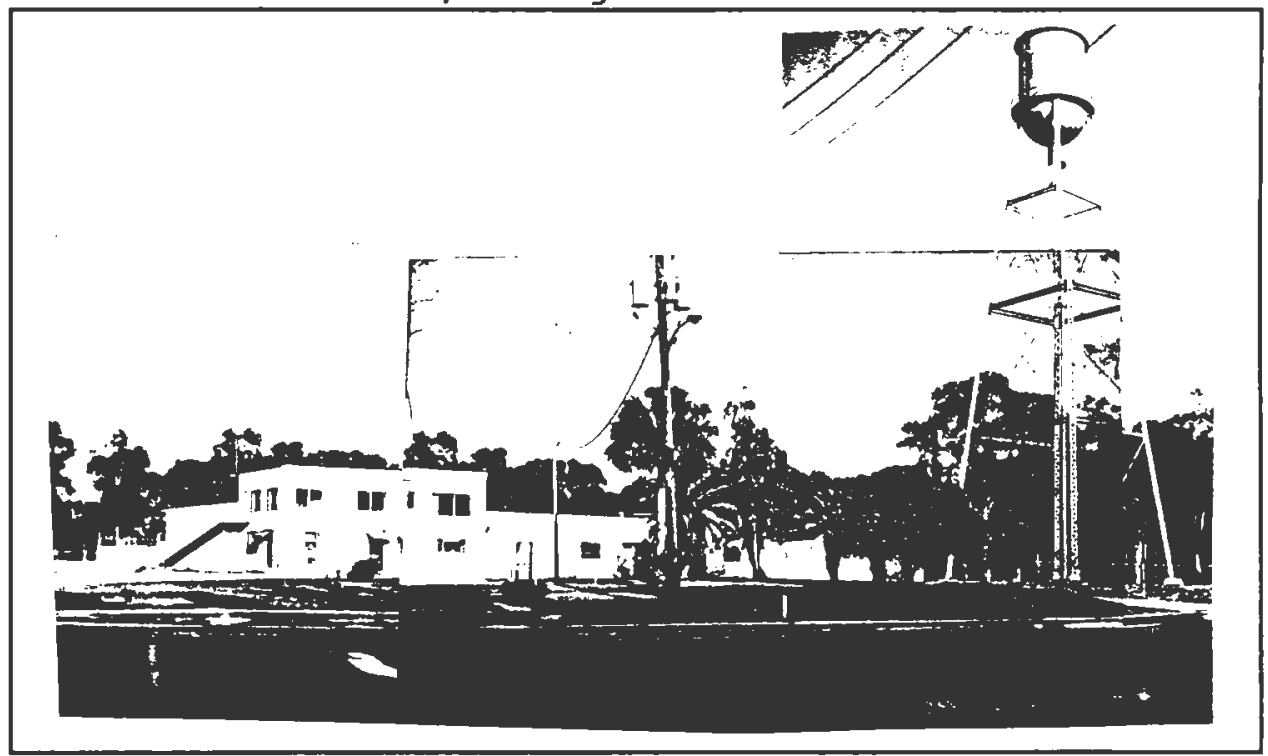

(Source: Photograph taken by the author during a site visit)

It was written in various newspapers at the turn of the century, that orange City had one of the finest water systems to date. Every orange grove and city resident had access to 
water via the underground system. ${ }^{13}$ The water was $99.1 \%$ pure, and thus, received the highest award possible at the 1903 st. Louis World's Fair. As a result of this recognition, the water was requested and shipped to all parts of the United States as well as Europe. Orange City's popularity escalated exponentially. This spring continues to supply orange city with water.

The second problem was associated with the periodic freezes which would destroy the orange crops. Unlike the irrigation problem, this dilemma had no solution except waiting until the next season. However, the Big Freeze of 1894 - 1895 was of such an intensity, that recovery was futile. ${ }^{14}$

"In the fall of 1894 , the 4000 acres of orange groves in and around orange city were thriving. Then, along came the Big Freeze. For many years every date in Florida was measured from it. It was in fact a double freeze. The first touch was on December 27, 1894 when the leaves blackened and shriveled, but the trees were not killed. The sap was driven to the twigs, so that there resulted a very unusual growth of flowers which covered the orange trees with a glory of bloom. January was an ideal month, balmy and pleasant. But then came the second freeze in February that spelled ruin. The air grew colder and colder. And, by morning the comfortable wealth of orange city was a thing of the past. The groves were blackened and dead"15

The devastation was felt City-wide. Due to the dependence upon this one crop, many of the residents were forced to leave for economic reasons. Some left the state of Florida altogether, while others moved to New smyrna (located north-east of orange (ity), and took up fishing for their 
livelihood. Orange city would not recover until many decades later.

The Great Depression of 1929 was even more of a devastating event in the history of orange city than the Big Freeze of 1894/95. Orange City, which had originally been founded on leased land, had not yet completed settling its account. And, as a result of the depression, payments could no longer be met by the townspeople. Therefore, a meeting was held and it was decided that approximately four/fifths of the area should be relinquished to the Florida Improvement Fund, holders of the original lease agreement. As an outcome of this decision, the size of orange city was reduced to one square mile. ${ }^{16}$ The Great Depression not only affected the land size of Orange city, but also the size of the population. Over the next three decades until 1950, not only did orange City's population not increase, but it actually lost a small portion. By 1950, the population of orange City was 742 . Therefore, orange City had a smaller population than during the great orange grove explosion of the mid-1880s (800 people in 1885). Since the 1950s however, orange city has grown by leaps and bounds. Through the annexation of land from Volusia county, orange City has increased from one square acre during the Great Depression to a present size of approximately six square acres (see Figure 2.3). This figure will further increase exponentially by the summer of 1994, because orange city is presently in the process of annexing large tracts of 
land located off of Enterprise Road and Saxon Boulevard to its south. The population of orange city has additionally escalated since the 1950s.

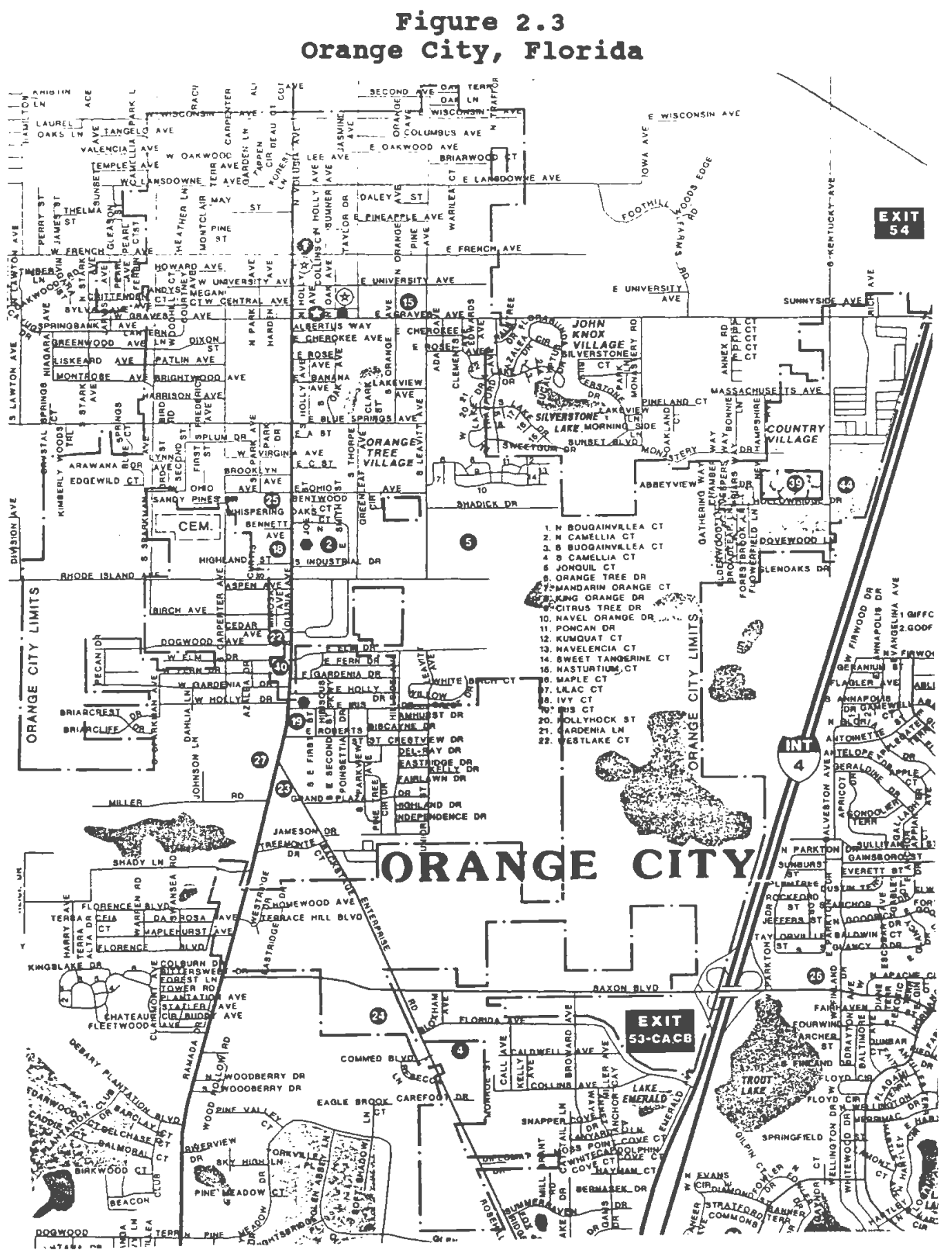

(Source: Mosher-Adams, Inc, Map of Orange City, Florida, 1993) 
Figure 2.4 demonstrates the increases in population which have occurred over time. As this indicates, orange city has seen a $672 \%$ increase between 1950 and 1992. Figure 2.4 also indicates that the population of orange city has been increasing by a two-to-one ratio over that of volusia county.

TIGORE 2.4

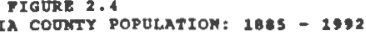

\begin{tabular}{|c|c|c|c|c|c|c|c|c|c|c|c|c|c|}
\hline " & 2885 & 2950 & 1960 & 2970 & 1980 & 1990 & 1912 & $2085-1992$ & $\begin{array}{r}P E \\
90-92\end{array}$ & $\begin{array}{l}\text { DIf } a n c \\
60-92\end{array}$ & $\begin{array}{l}\text { Conuras } \\
70-92\end{array}$ & $0-92$ & $10-92$ \\
\hline orange city & 800 & 742 & 1,123 & 1,777 & 2,795 & 5,347 & 5,734 & 6168 & 6728 & 4108 & 2228 & 1058 & 78 \\
\hline voluale county & • & - & 125,319 & 169,487 & 258,762 & 370,712 & 383,983 & - & - & 2068 & $126 \%$ & 481 & 38 \\
\hline
\end{tabular}

Though, it is true that orange city's population is growing at a much faster pace than that of the county's, one must bear in mind that Volusia county loses population every time a portion of itself is annexed by a surrounding community. Therefore, this is not a true measure of the magnitude at which a city is growing. The true test lies in examining a specific areas growth over time, and as the chart clearly demonstrates, orange city is flourishing at a vast pace.

U8 ROUTE 17-92

The earliest trace of anything resembling the thoroughfare which exists today, dates back to the mid-1800's when the path was naturally developed by the early settlers and their horses and wagons (Illustration 2.3). 
Ilustration 2.3

Photograph taken in the $1880 \mathrm{~s}$

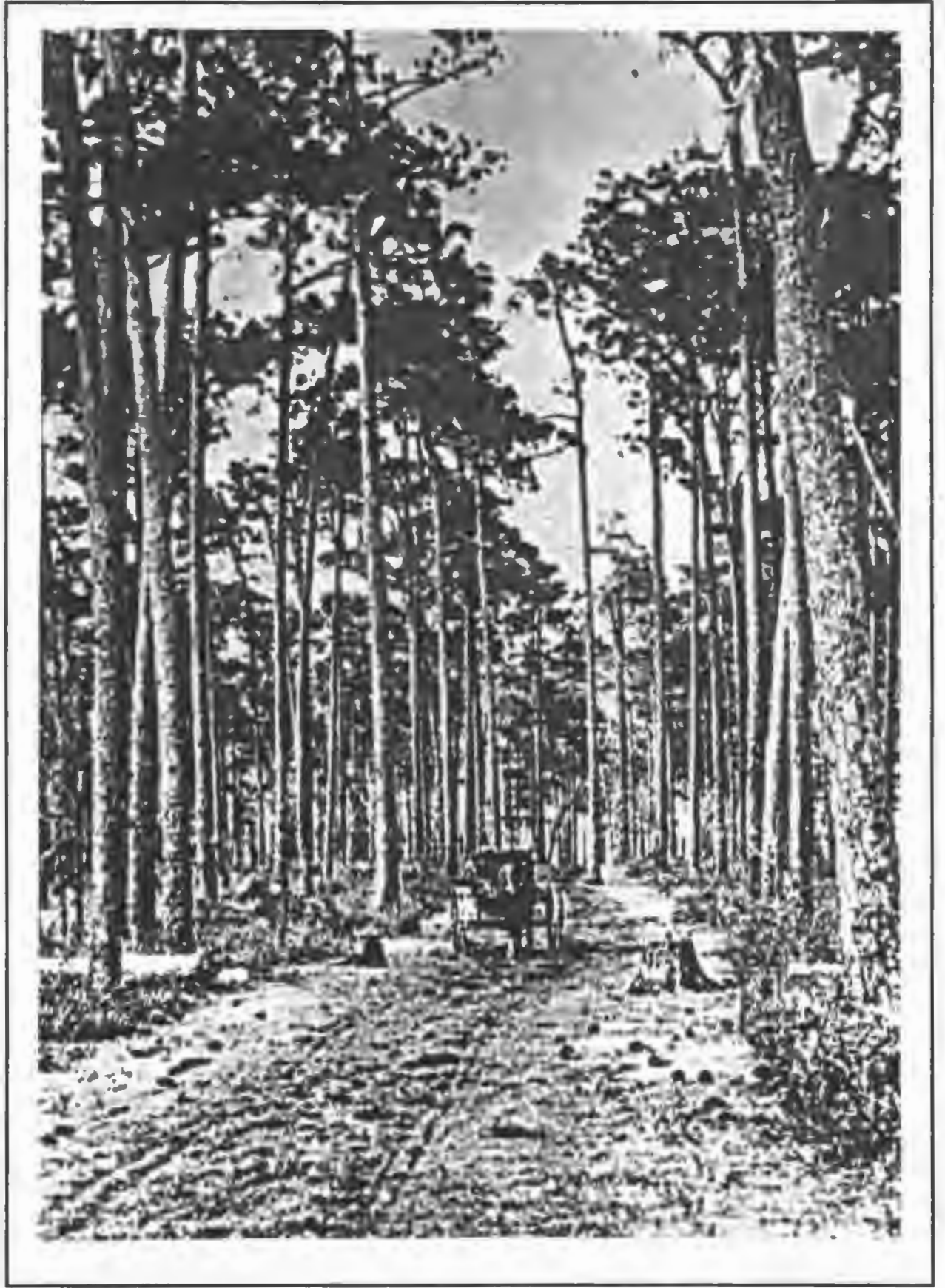

(Source: Bill Dreggors, West Volusia Historical society) 
The path would remain in this rustic condition for some decades. However, though the condition of the road itself would not be improved for some years to come, the aesthetic appearance of the roadway was greatly enhanced by the city's first occupants.

In the $1870^{\prime} \mathrm{s}$, when orange city was just beginning to be discovered and inhabited, property taxes were instituted as a means of initiating city services. As a means of lessening the financial burden that these taxes caused as well as improve the aesthetic appearance of the community, the original city council initiated a proclamation which allowed a 25 cent tax exemption for all those whom planted an oak tree outside his home alongside the roadway. ${ }^{17}$ Volusia Avenue (US Route 17-92) and all existing principal streets were immediately inundated with oak trees (Illustration 2.4).

Several years later, the Village Improvement Association (a local group of women who joined in an effort to beautify and enrich the community) purchased crushed shells and had the first sidewalk placed on portions of Volusia Avenue. ${ }^{18}$ This was then followed by the placement of gas lamps and pedestrian amenities, such as trash receptacles. The early 1900's was also the decade in which the two-laned thoroughfare (Volusia Avenue) was improved through the placement of crushed shells. These shells were carted from nearby Indian middens ${ }^{19}$ at Blue springs and deposited on the trail. 
Illustration 2.4

Turn of the Century Photograph of Us Route 17-92

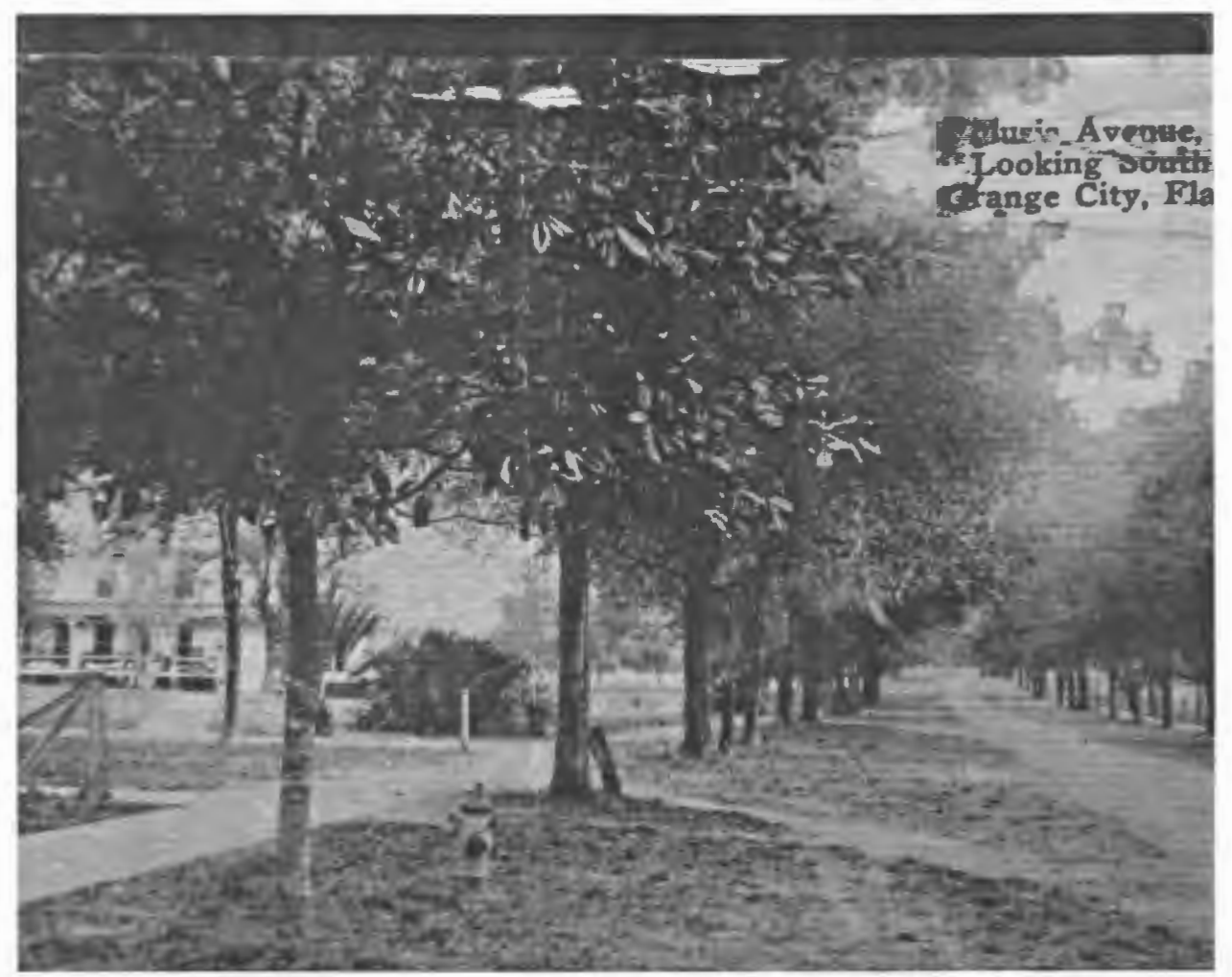

(Source: Carol Goose, Local Orange City Historian)

Even with such improvements, Volusia Avenue remained a crude form of transportation with little access to outlying communities. It was the vision of Deland (adjacent Orange city northern town) Mayor Earl Brown to develop a trail which would connect Canada to Florida. He personally visited each and every mayor along the proposed trail, which presently existed as a series of unmarked dirt roads, with his idea. The road construction was performed by a variety of laborers, including prisoners - so called "chain gang" (Illustration $2.5)$. 


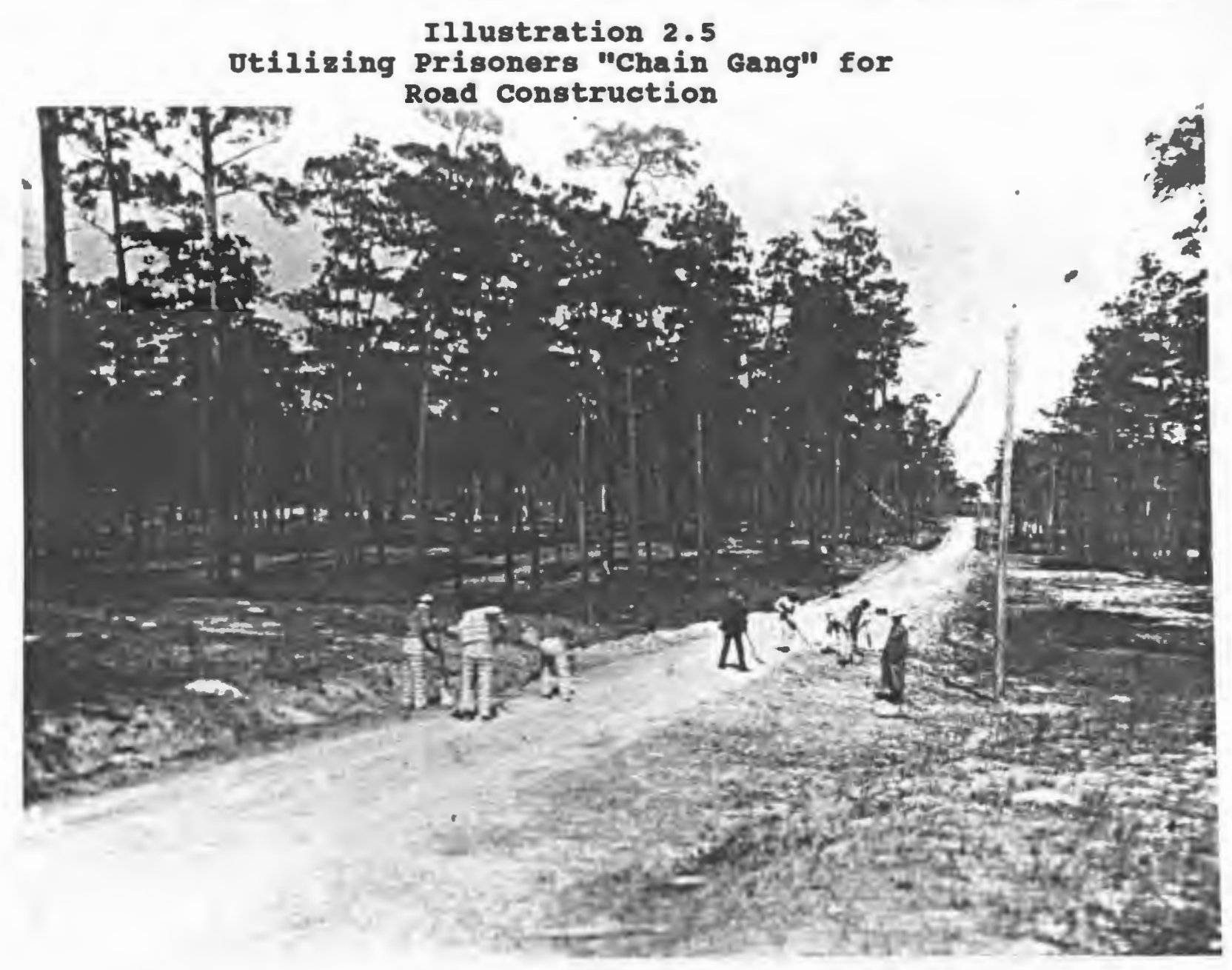

(Source: Bill Dreggors, West Volusia Historical society)

His hard work and perseverance would result in the completion of the trail on April 13, $1926 .{ }^{20}$ Volusia Avenue would eventually be incorporated into this network.

"The "Black Bear Trail" meandered through more than 1,400 miles of scrub growth, towns, farms and forests stretching from balmy Punta Gorda, Florida to the more nippy climate of Ottawa, Canada.....Although the Black Bear Trail was not paved, it was serviceable...The Trail through Orange city reportedly was about as wide today's US 17-92."21 
The reason for naming the highway as they did, was because the black bear was native to every state in which it crossed.22 In the mid-1930's the trail was once again infrastructurally improved. Glazed bricks were laid upon the roadway and affixed with a mixture of concrete, sand and water. ${ }^{23}$ During the mid-1940s is when the next big construction phase occurred. However, this time it was not highway related. It was during this period when telephone poles and electrical lines were introduced.

Illustration 2.6

Placement of Telephone Poles and Electrical Lines in orange city

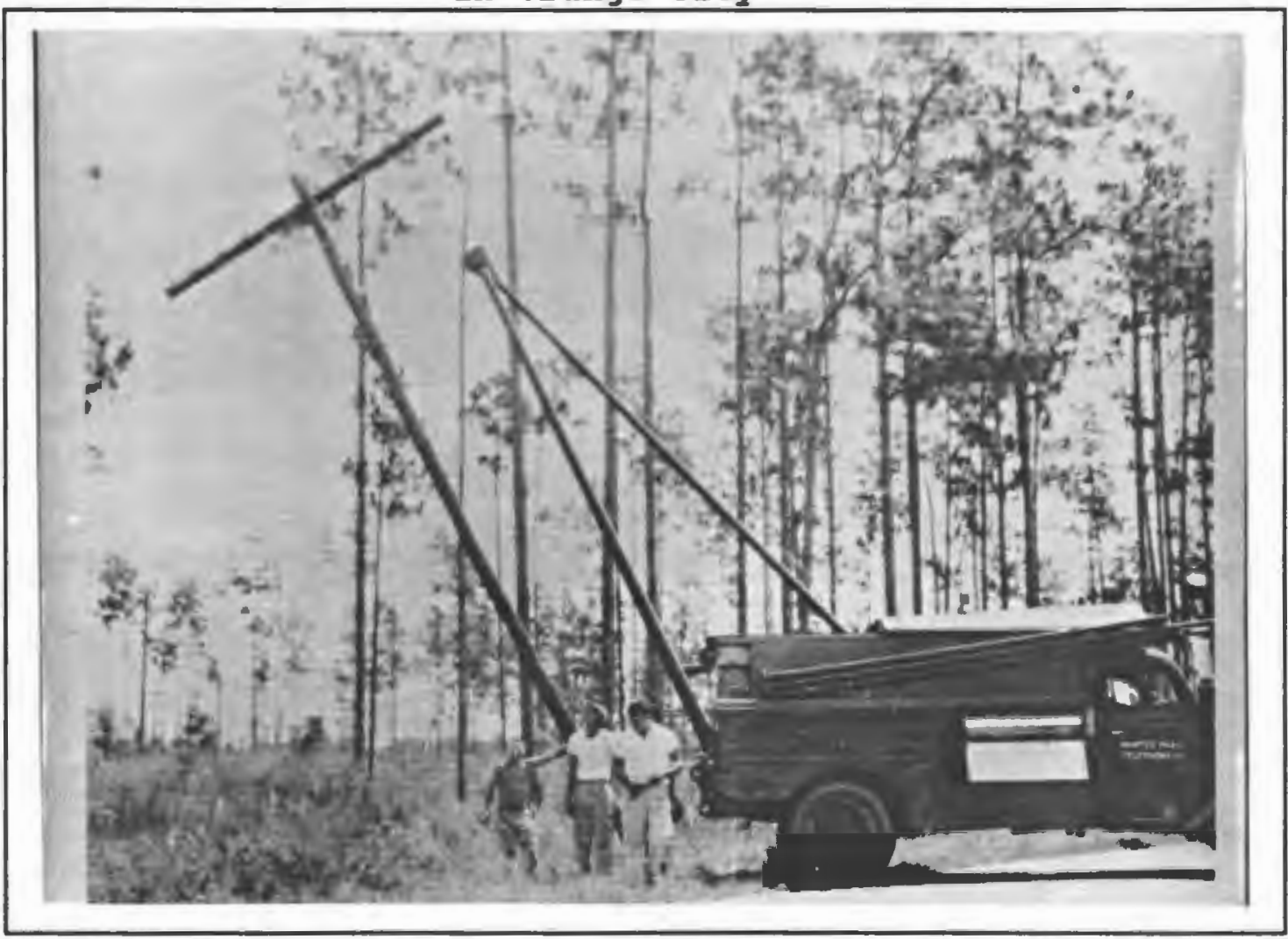

(Source: Carol Goose, Local Orange City Historian) 
US Route 17-92 remained in a similar state for the next 20 years, until the latter part of the 1960's. During this period tremendous change occurred. The oak trees which had existed for some nine decades were cut down and the roadway widened to four lanes. In addition, the glazed bricks were removed and the entire stretch of road paved in the name of progress. Since the 1960s, however, not much change has occurred to US Route 17-92.

Recently, there was a proposal by the Department of Transportation to widen US Route 17-92 from four to six lanes. Computer models were conducted in order to demonstrate how US Route 17-92 would be impacted by increasing traffic volumes in the future. The models it seems, indicated that unless something were done, US Route $17-92$ would be unable to handle anticipated traffic volumes. Therefore, conceptual plans were drawn and construction seemed imminent. However, there was such an uproar and opposition from orange city residents, that the Department of Transportation terminated the idea. Instead, the Department of Transportation has decided to eliminate on-street parking and widen the existing lanes. US Route 17-92 is expected to be widened sometime in either May or June, 1994. Illustration 2.7 displays US Route 17-92 as it appears today. 
Illustration 2.7

Photograph of 08 Route 17-92 as it Appears Today

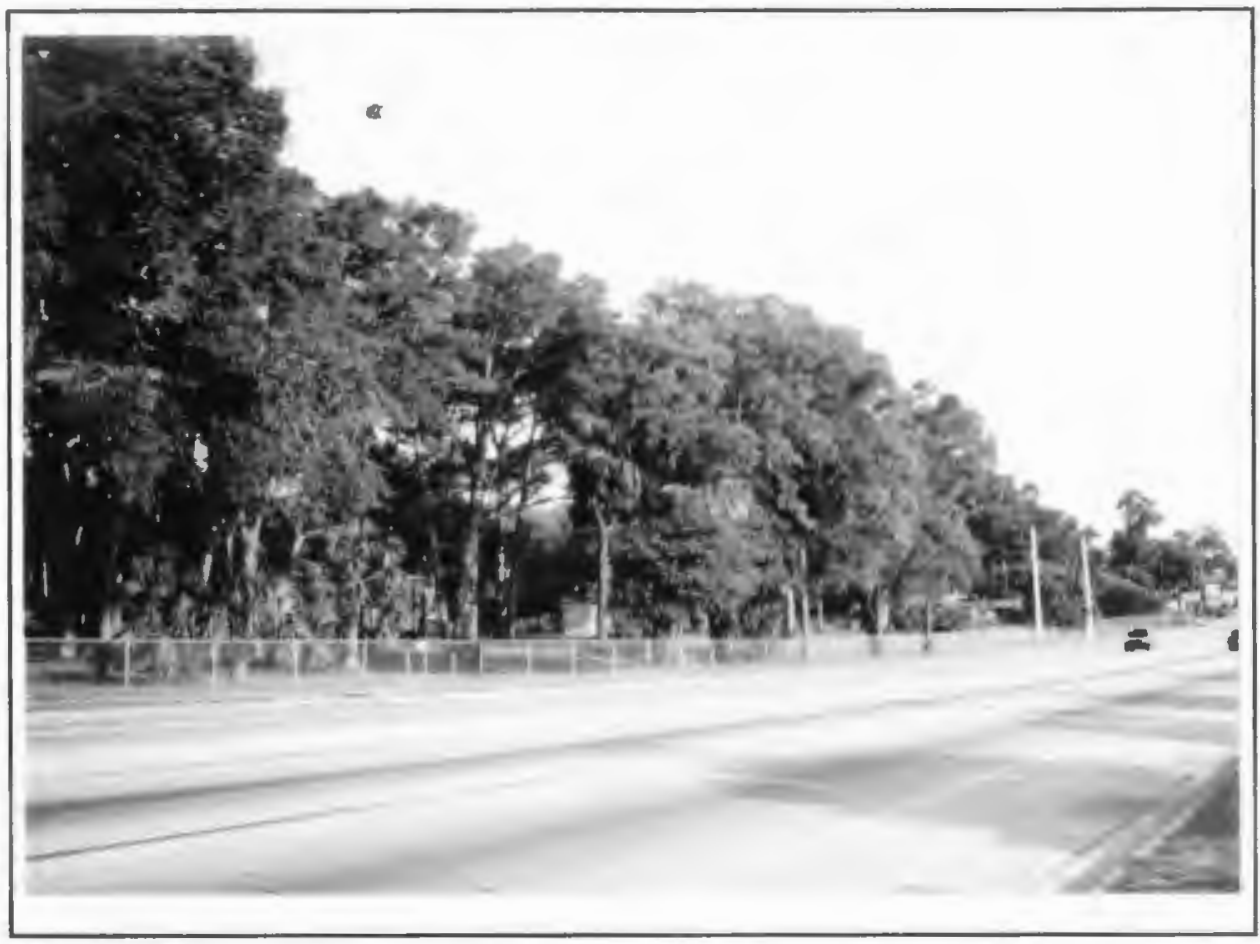

(Source: Photograph taken by the author during a site visit) 
${ }^{1}$ Charlton W. Tebeau, A History of Florida (Coral Gables, Fl.: University of Miami Press, 1971), 16.

${ }^{2}$ Village Improvement Association, our story of orange City, Florida (Deland, Florida: Carter Printing Co, 1975), 14.

${ }^{3} \mathrm{Mr}$. Dallas wittgenfeld, interview by author, 10 october 1991, Orange city, Florida, tape recording, X-Pert Travel Agency, Orange City, Florida.

${ }^{4}$ Ibid.

"Land given to the state of Florida by the National Government, to be sold for not less than $\$ 1.25$ per acre and the proceeds to be used for public works of different kinds." (Village, our story, 31.)

${ }^{6}$ Ibid.

${ }^{7}$ Ibid. , 6.

${ }^{8} \mathrm{Mr}$. James Kerr, Orange city Planning and zoning coordinator, interview by author, 25 october 1991, orange city, tape recording, orange city Town Hall, Orange City, Florida, .

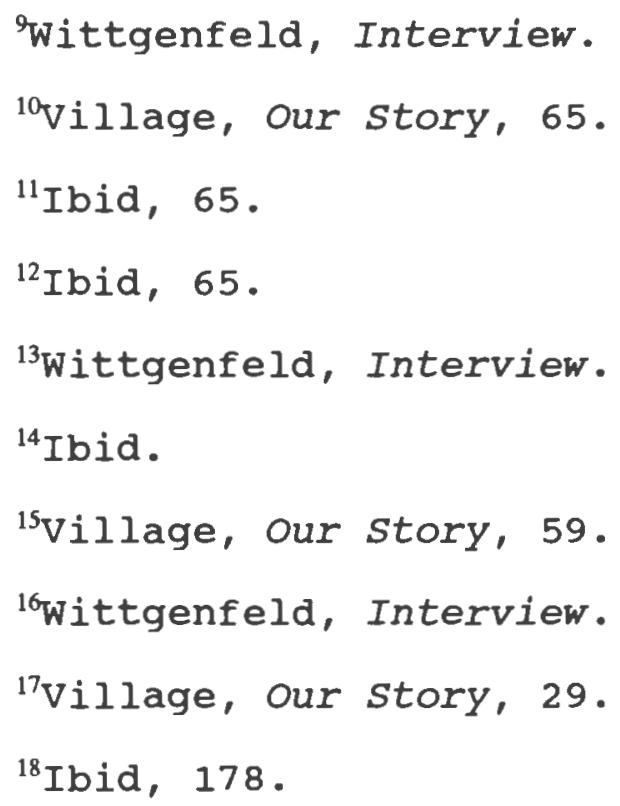

${ }^{19}$ Indian-made shell mounds - so called "Indian Refuse Sites". (Mr. Bill Dreggors, interview by author, 28 February 1994, Deland, Florida, oral, West Volusia Historical Society, Deland, Florida). 
${ }^{20}$ Village, our story, 29.

${ }^{21}$ Staff, "Black Bear Trail," Daytona Beach News Journal: Deland Bureau. (Date is unknown, however, a copy is filed with the Volusia County Library Center, City Island, Daytona Beach, Florida)

${ }^{22}$ Ibid.

${ }^{23}$ Dreggors, Interview. 
This chapter describes the existing nature of those components which are directly impacting US Route 17-92, and in turn, the quality of life in orange city. These components include, an analysis of traffic conditions, automobile accidents and condition of roads. In addition, the businesses which exist along the highway, including their form, massing and architecture are assessed. Private and public signage, customer parking areas, area-wide landscaping as well as pedestrian amenities and movement are likewise evaluated. And lastly, this chapter concludes with a short commentary on those focal points which exist in orange city and promote its rich heritage.

\section{TRAFFIC ANALYSIS}

Average Daily Trips and Levels of Service

US Route 17-92 has experienced tremendous commercial growth over the past decade. This has resulted in increased traffic volumes. However, the reason behind the recent exponential increase in traffic volume, is due to the enormous commercial growth on Enterprise Road. Enterprise Road which intersects Route 17-92 at the southern end of Orange City, has been the site of two commercial outdoor malls, a large Department store (Target) and a variety of smaller businesses.

The following analysis is a synopsis of the data presented in Table $A .1$ in the appendix. The portion of US Route 17-92 which is located within the project area (see 
Figure 3.1), experienced an overall average increase in traffic volume of $125.7 \%$ between 1978 and 1992 . During this same time period, the greatest increase $(171.0 \%)$ occurred on the section of US Route 17-92 located between Enterprise Road and Blue Springs Avenue. This demonstrates that Enterprise Road is the big attraction in the area, and in turn the motivation for the exponential increase in traffic volumes. The smallest increase $(73.0 \%)$, though only in comparative terms, occurred between Graves Avenue and French Avenue.

During the 1989 - 1992 period, US Route 17-92 experienced a slight decrease in traffic volumes, with the greatest decrease (3.2\%) occurring between Graves Avenue and French Avenue. In fact, the same stretch of US Route 17-92 saw a 10.1\% decrease in traffic volumes during the 1991 - 1992 period. However, even with this decrease, the level of service along this section of US Route 17-92 remained at "C", which is the maximum allowable level of service permitted in the Comprehensive Plan. On the other hand, Blue springs Avenue to Graves Avenue has experienced a steady increase throughout the past fifteen years. Between $1978-1992$, there was a $117.7 \%$ increase in traffic volume. The same stretch of highway experienced a $13.9 \%$ increase in traffic between 1990 1992, and a staggering 21.8\% increase during the 1991 - 1992 period.

The entire expanse of US Route 17-92, from Enterprise Road to Graves Avenue, is currently operating at a "F" level 

of service. On average, these two sections of highway carry 34,500 vehicles a day, which is in excess of the allowable capacity $(29,100)$ by 5,400 vehicles a day. Illustration 3.1 displays daily traffic on us Route 17-92.

Illustration 3.1 Daily Traffic on 08 Route 17-92

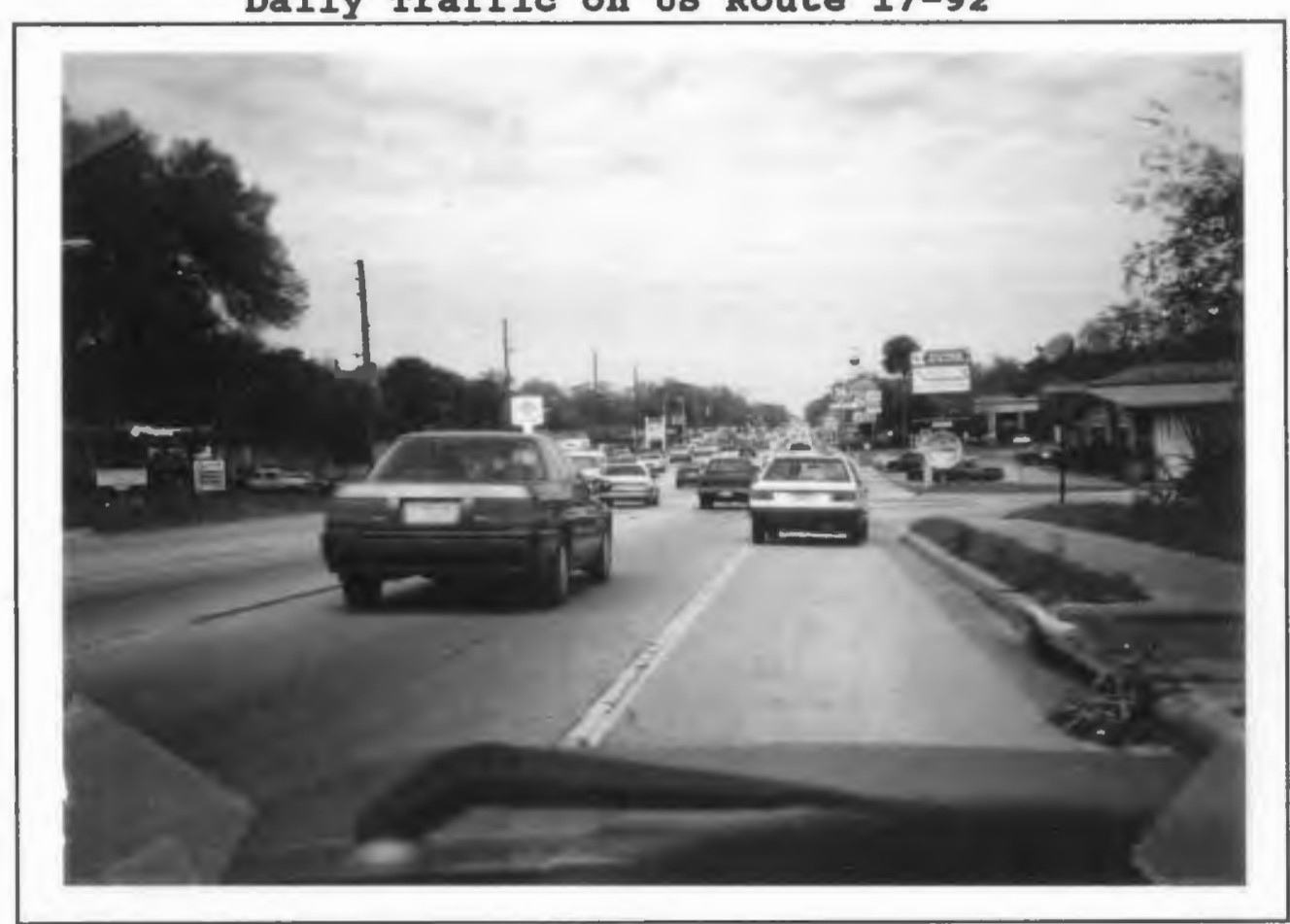

(Source: Photograph taken by author during a site visit)

For most part, the primary east-west US Route 17-92 bisectors have not reached their maximum allowable capacities. Though, experiencing a slight increase in overall traffic volumes, they are still within acceptable standards. In 1993, the average increase in traffic volumes for East Graves, French, Minnesota and West New York Avenues was a mere $4.8 \%$. In fact, both East Graves and French Avenue experienced a 
slight decrease in traffic in 1993. The only increase of any proportion (18.7\%), occurred on Minnesota Avenue east of US Route 17-92. However, even this increase is minimal in regards to the maximum allowable capacity.

East Graves Avenue, both east and west bound, is currently carrying an average of 4,910 vehicles a day. The maximum allowable capacity as permitted in the comprehensive Plan is 6,246 vehicles. Therefore, Graves Avenue is still 1,336 vehicles $(21.4 \%)$ shy of the maximum allowable capacity. French Avenue, both east and west bound, is currently carrying 3,727 vehicles a day. The maximum allowable capacity as permitted in the Comprehensive Plan is 11,390 vehicles. Therefore, French Avenue is still 7,763 vehicles (67.3\%) shy of the maximum allowable capacity. Minnesota Avenue, both east and west of US Route 17-92, is currently carrying an average of 1,748 vehicles a day. The maximum allowable capacity as permitted in the Comprehensive Plan is 11,390 vehicles. Therefore, both sections of Minnesota Avenue on average, are still 9,642 (84.6\%) shy of the maximum allowable capacity. West New York Avenue, both east and west of US Route 17-92, is currently carrying an average of 3,886 vehicles a day. The maximum allowable capacity as permitted in the Comprehensive Plan is 11,390 vehicles. Therefore, both sections of West New York Avenue on average, are still 7,504 (65.9\%) shy of the maximum allowable capacity. 
Both Enterprise Road and Saxon Boulevard (which is situated south-east of US Route 17-92 and intersects Enterprise Road at the location of the two outdoor commercial malls) must be discussed due to their current impact upon the traffic situation on US Route $17-92$ and their future usage. Enterprise Road, both north and south bound, is currently operating at a "B" level of service, except for the section south of Saxon Boulevard which is at a "D" level. On average, Enterprise Road is currently carrying 13,034 vehicles a day. The maximum allowable capacity permitted by the comprehensive Plan is 25,100 for all sections of Enterprise Road, except for the section located south of Saxon Boulevard, which should be handling no more than 24,700 vehicles a day. Therefore, Enterprise Road is 12,066 vehicles (48.1\%) shy of the maximum allowable capacity. Saxon Boulevard likewise is operating well below the permitted level of service. It is currently operating at a "B" level, whereas, the Comprehensive Plan permits no less than an "E" level of service. The section of Saxon Boulevard situated to the east of Enterprise Road, both east and west bound, is currently carrying 9,207 vehicles a day. The maximum allowable capacity permitted in the Comprehensive Plan is 24,700 vehicles a day. Therefore, the eastern section of Saxon Boulevard is $15,493(62.7 \%)$ shy of the maximum capacity allowable. The western section of saxon Boulevard is not crucial to the project, and thus is not discussed. 
The facts speak for themselves. Whereas, US Route 17-92 is reaching the critical stage and cannot handle any additional traffic, the primary bisectors are able to withstand further increases. Furthermore, the traffic volumes on both Enterprise Road and Saxon Boulevard are well under the maximum allowable capacity, and thus, are able to offer relief.

Public Transportation

Public transportation does not exist in either orange City or in the surrounding vicinity. Their was discussion in December, 1991, of establishing a bus route in the orange city - Deland area, thereby developing a west volusia route which would encompass several communities. However, due to the inability to meet certain orange city requirements and thus their refusal to participate, the entire proposal was eliminated. ${ }^{1}$

\section{Accidents}

The situation along US Route 17-92 has been steadily getting worse due to the intensification of traffic, inability to traverse Route 17-92, inability to safely gauge turns at intersections, improper usage of the middle left-hand turn lane (which has become locally referred to as "The suicide Lane") and the diminishing ability of many drivers to handle these increasing hazardous road conditions. These concerns 
are directly related to the number and severity of accidents which have occurred along Us Route 17-92. As Table 3.1 shows, in the six year period between 1987 and 1992, 376 accidents occurred along the three mile stretch of US Route 17-92, from Enterprise Road to Michigan Avenue. ${ }^{2}$ As a result of these accidents, 472 persons have been injured and one killed. However, as staggering as these numbers may seem, the actual number of accidents may even be higher. It is purported that upwards of $50 \%$ of all accidents are not reported, due to Florida's "No-Fault Insurance" law and its immediate impact upon a person's insurance rate once the accident is reported. ${ }^{3}$ Tables A.2 through A.4 in the appendix, indicate the location of all accidents within the project area for the $1987-1992$ time period.

of the 376 accidents which have occurred during this six year period, 244 or $64.9 \%$ of all accidents and 294 or $62.3 \%$ of all injuries have occurred at intersections. Furthermore, of the remaining 132 accidents which have not occurred at an intersection, 45 or $34.1 \%$ of them transpired as a direct result of a nearby intersection. The Volusia county Department of Transportation has stated in its "Crash Detail Report" that nearby intersections were the contributing cause of these 45 accidents. Therefore, in total, intersections have either been the direct cause of or have contributed to 76.9\% of the accidents between 1987 and 1992 . 
Table 3.1

Accidents and Resulting Injuries: 1987 - 1992

\begin{tabular}{||l|l|l|l|l||}
\hline & $1987-1989$ & $1990-1991$ & 1992 & TOTAL \\
\hline $\begin{array}{l}\text { Number of } \\
\text { Accidents: }\end{array}$ & 192 & 132 & 52 & 376 \\
\hline $\begin{array}{l}\text { Number of } \\
\text { Injuries: }\end{array}$ & 208 & 198 & 66 & 472 \\
\hline $\begin{array}{l}\text { Number of } \\
\text { Deaths: }\end{array}$ & 0 & 1 & 0 & 1 \\
\hline
\end{tabular}

(Source: Bill Linkovich of the Florida Department of Transportation in DeLand, Florida)

Though, over $90 \%$ of all intersections located along US Route 17-92 within the project area have been the scene of accidents, there are several which have experienced beyond the norm (see Figure 3.2). At the intersection of ohio Avenue and Route 17-92 there have been 32 accidents, and a resulting 36 injuries. This intersection has also contributed to four additional accidents. At the intersection of Graves and Route 17-92, 32 accidents have occurred with a resulting 22 injuries. The intersection has contributed to one additional accident. At the intersection of Blue springs and Route 1792,25 accidents have occurred with a resulting 25 injuries. The intersection has contributed to three additional accidents. At the intersection of Enterprise Road and Route 17-92, there have been 17 accidents, and a resulting 31 injuries. The intersection has contributed to an additional 8 accidents. At the intersection of French Avenue and Route 


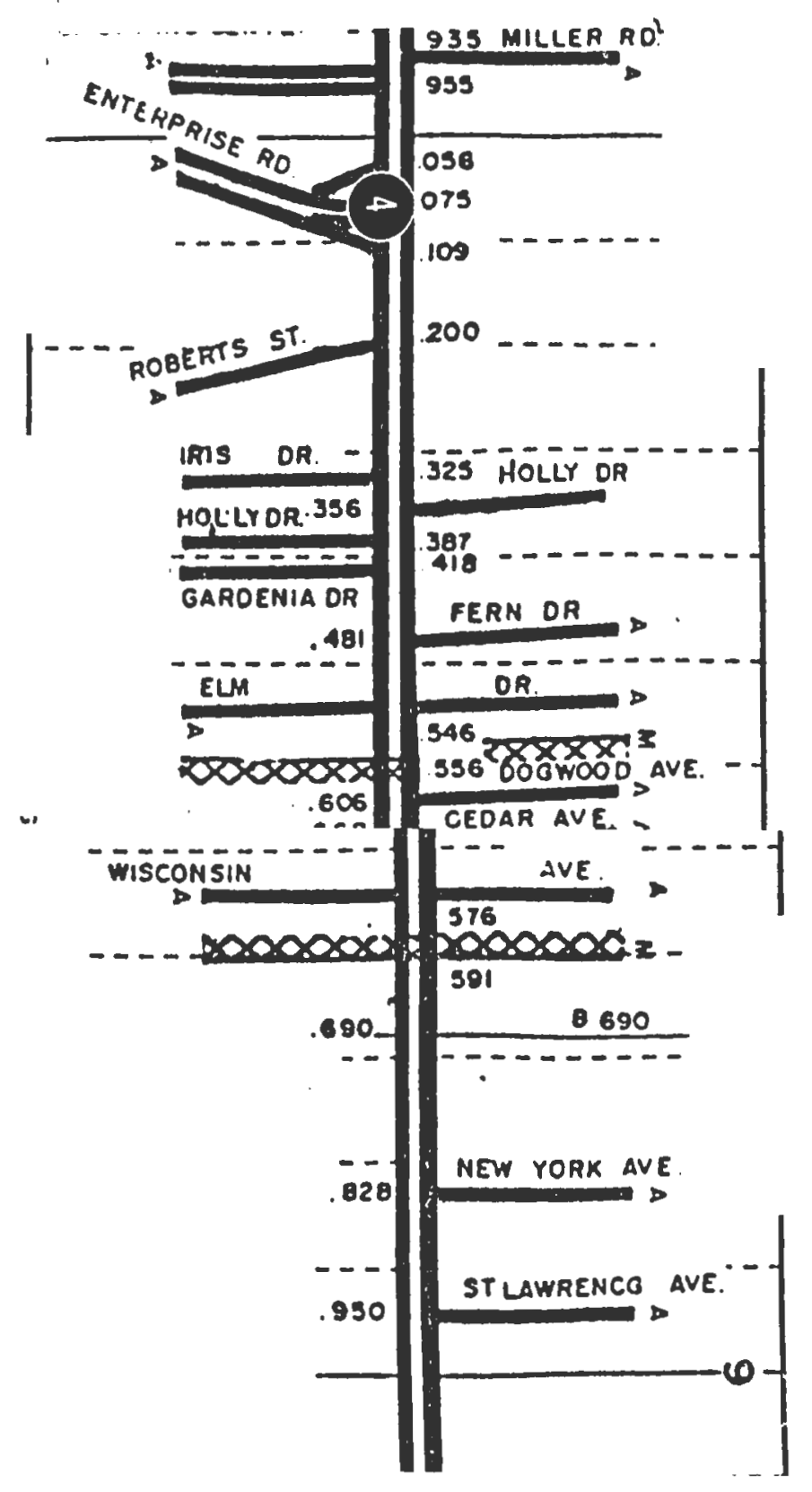

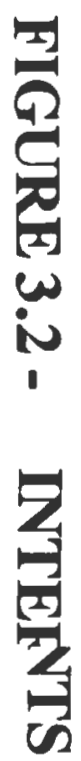


17-92, there have been 14 accidents with a resulting 21 injuries. The intersection has contributed to one additional accident. And, at the intersection of North Industrial Drive (Post office location) and Route 17-92, there were 12 accidents with a resulting 18 injuries. This intersection contributed to three additional accidents. All previously mentioned intersections have traffic lights except for North Industrial Drive.

The remaining intersections have experienced anywhere from one to ten accidents and a resulting range of zero to fourteen injuries. They have contributed to several additional accidents each.

The remaining accidents have occurred between intersections, including the one death. Though, not detailed in this report, many of the accidents have involved several vehicles. The reasons for this are due to increased traffic volumes, lack of attention to the posted $45 \mathrm{mph}$ speed limit, and especially, unrequired tailgating habits of many drivers. Many factors have contributed to this exorbitant rate of accidents. However, the two leading reasons which have been expressed are the more conservative driving skills of the elderly, especially in regards to driving well below the posted speed limit, and the inability of all drivers to safely enter and exit the middle left-hand turn lane. The elderly will tend to come to a full stop on Route 17-92 prior to executing a turn at an intersection. The middle left-hand 
turn lane has become the focus of attention due to its ineffectiveness at safely removing traffic from the primary north-south lanes of travel, and aiding them in their lefthand turn commitment. Drivers from both directions are able to enter the middle lane at will, thereby, perpetrating a hazardous situation. Furthermore, drivers who visit businesses on one side of the Route and then wish to traverse to the opposite side will tend to utilize the middle lane as a safety zone, due to the large volume of traffic and the inability to safely navigate the crossing in a single attempt. This in turn creates a greater hazard for those drivers entering the middle lane from their respective lane of travel. They must not only contend with drivers entering from the opposite direction, but also those who are utilizing it in the process of crossing the road. Drivers have expressed the danger in negotiating turns onto as well as off of US Route 17-92. One must be ever vigilant of all three avenues of travel; from the north, the south and the middle left-hand turn lane. Illustration 3.2 contains photographs llooking both east and west-bound) of the seven primary US Route 17-92 bisecting roads (intersections). These include, wisconsin (the northern border of the project area), French, Graves, Blue Springs, Ohio, and Rhode Island Avenues. North Industrial Drive is also included because many residents and business owners have stated that this is an extremely dangerous intersection. 
ILLUSTRATION 3.2 - PHOTOGRAPHS OF THE PRIMARY US ROUTE 17-92 INTERSECTING ROADS

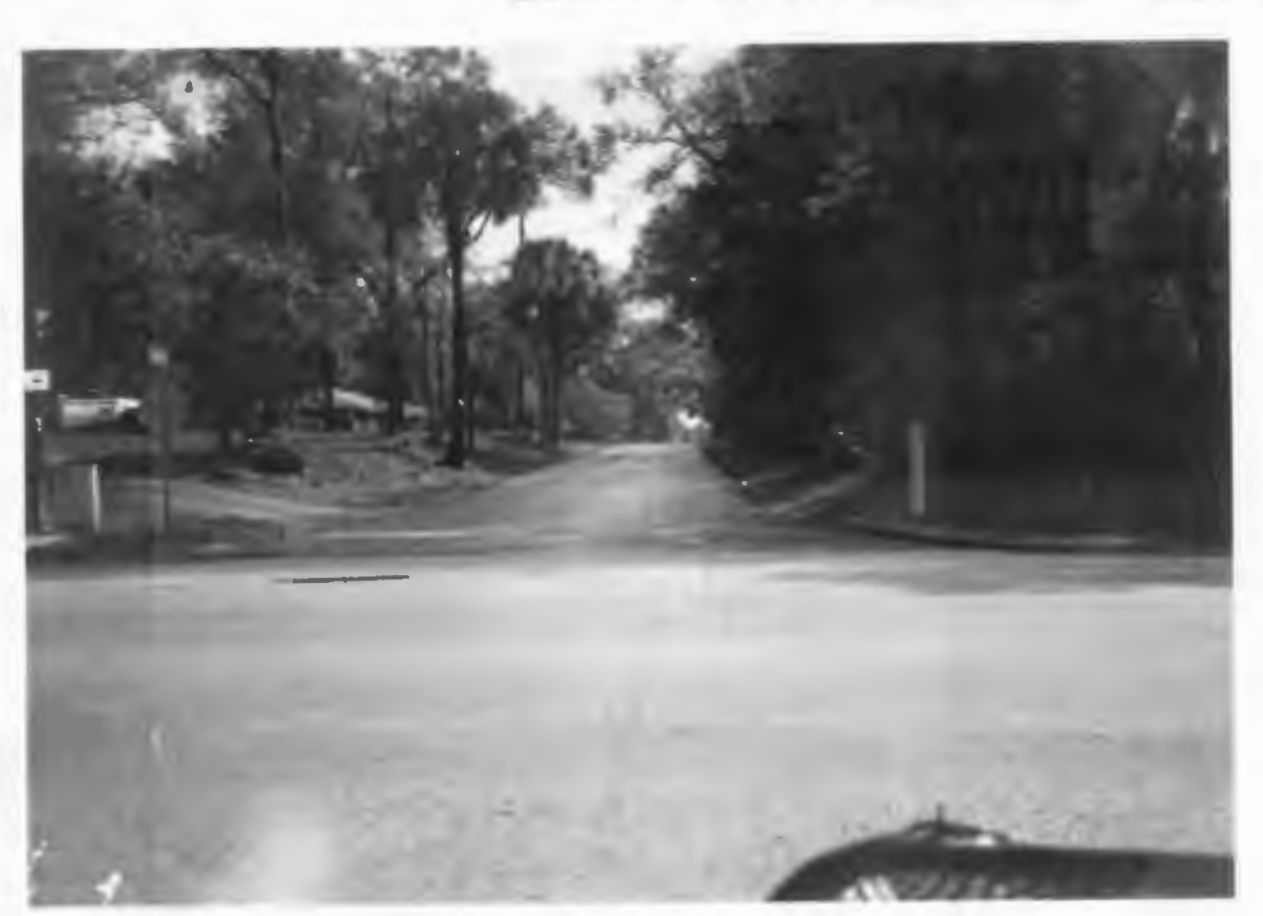

Wisconsin Avenue looking east.

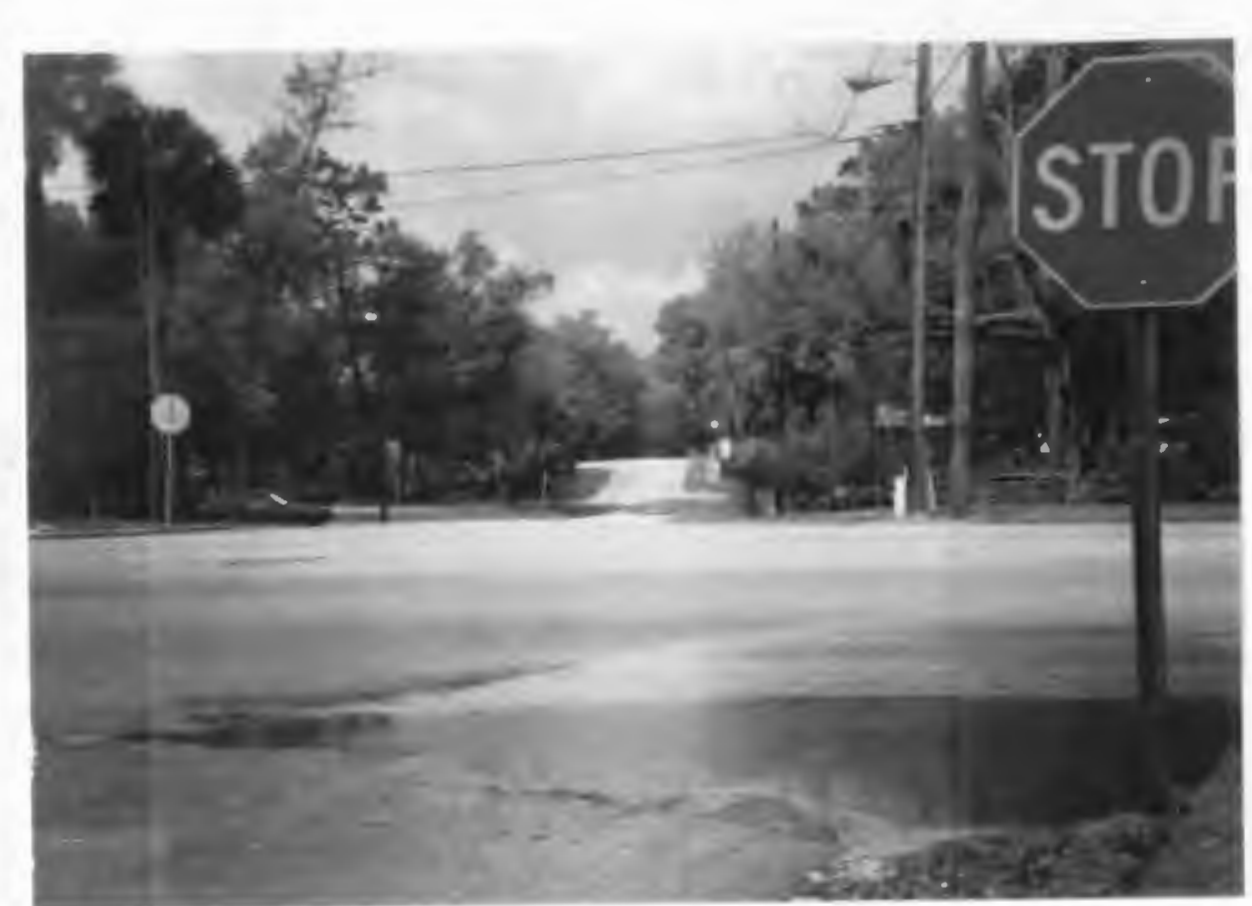

Wisconsin Avenue looking west.

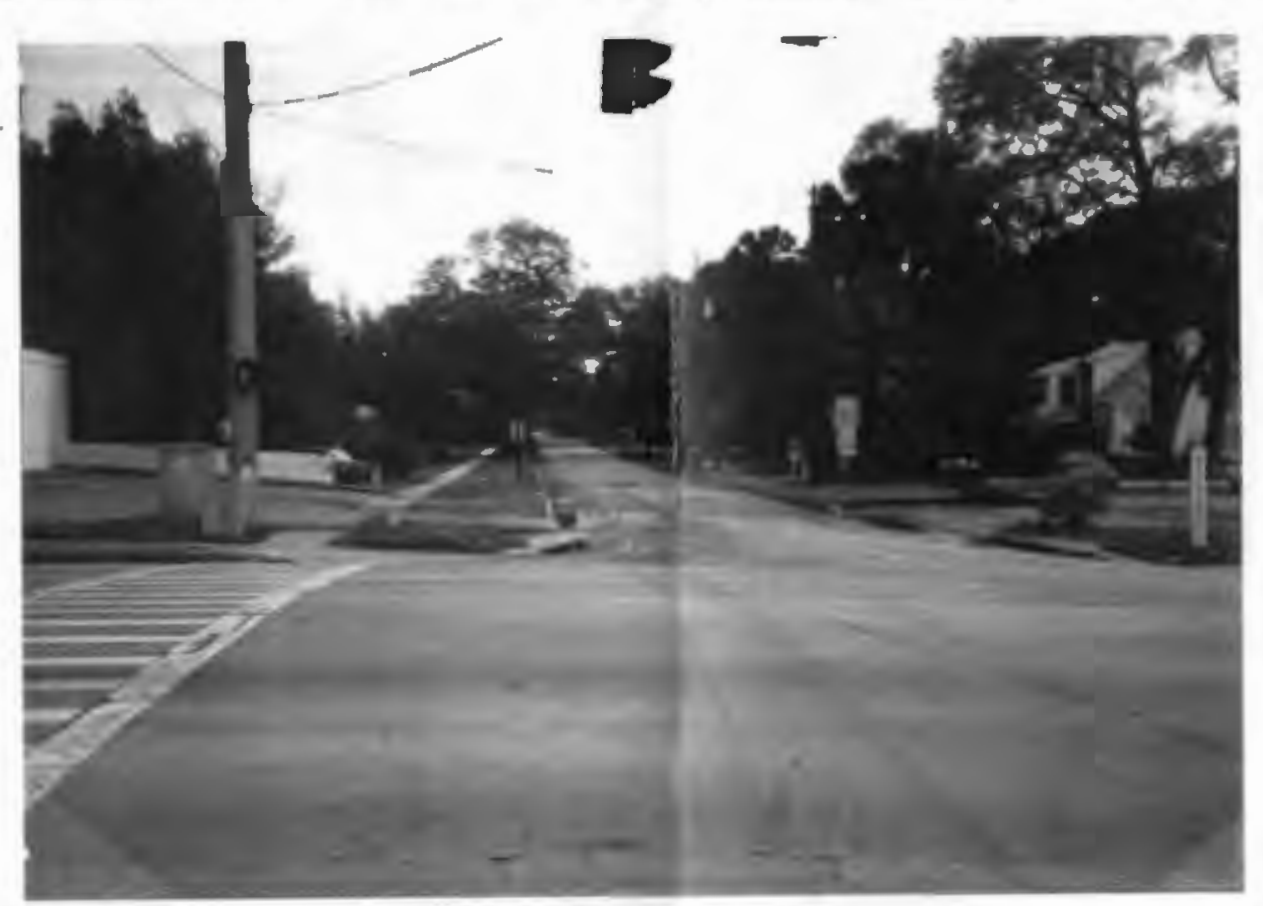

French Arenue looking east.

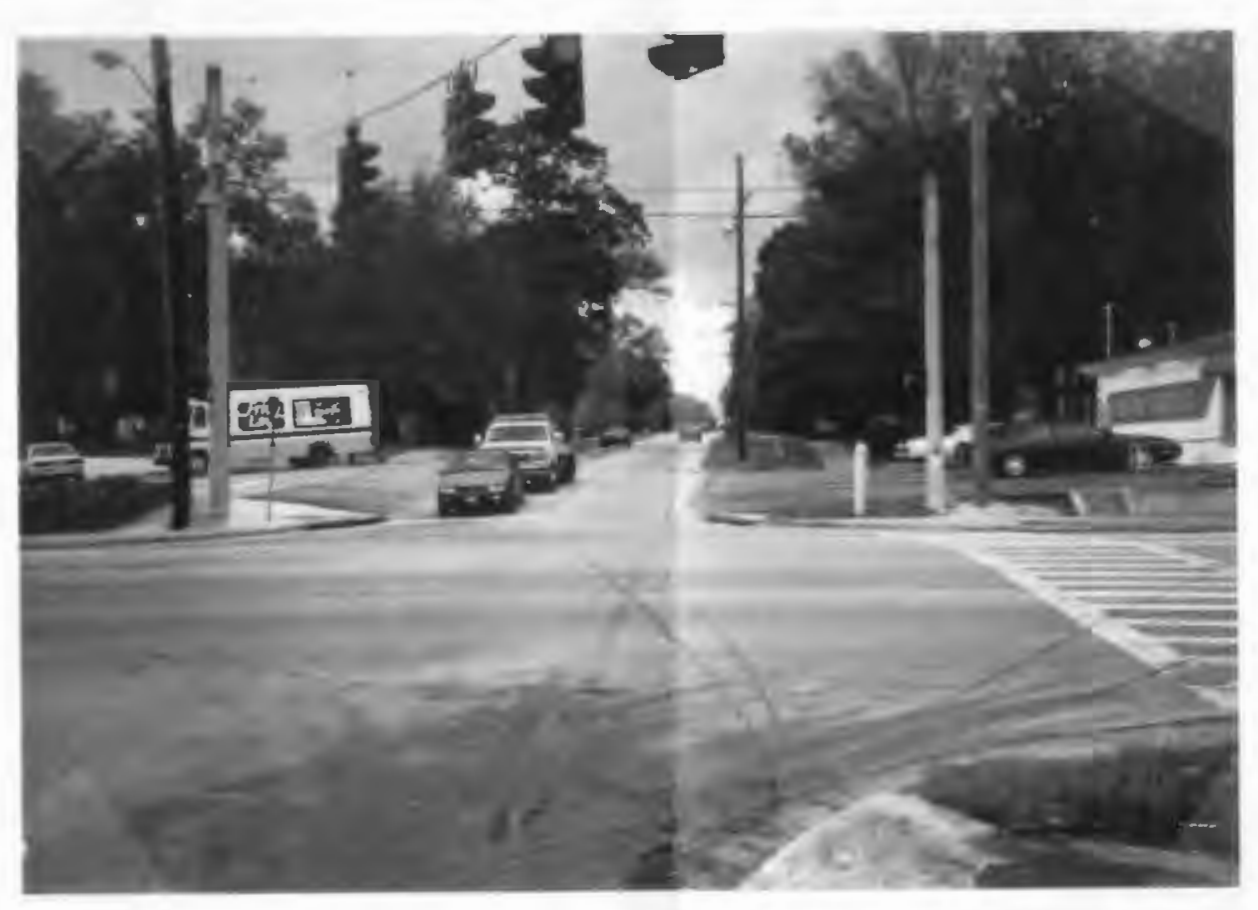

French Avenue looking west.

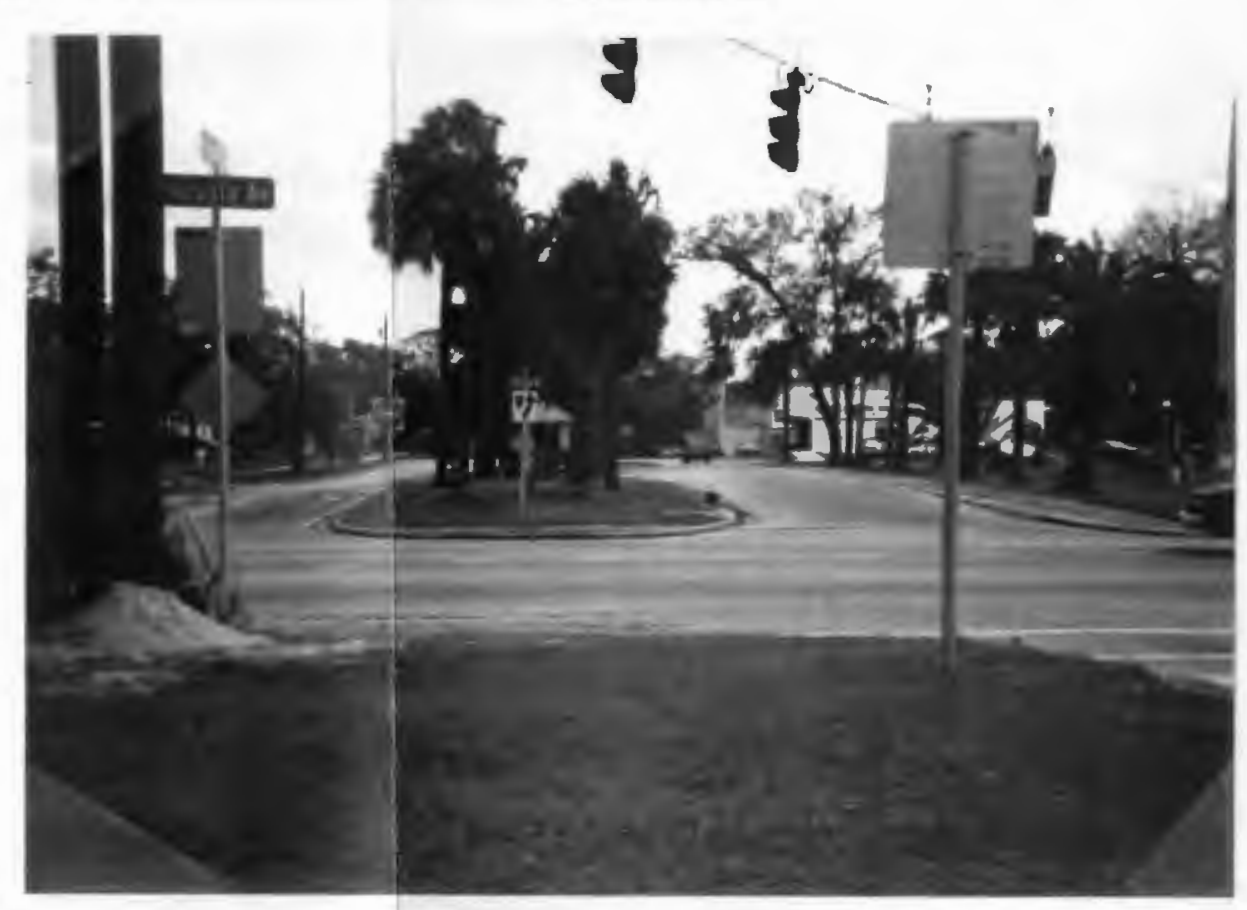

Gratros Avenue looking east.

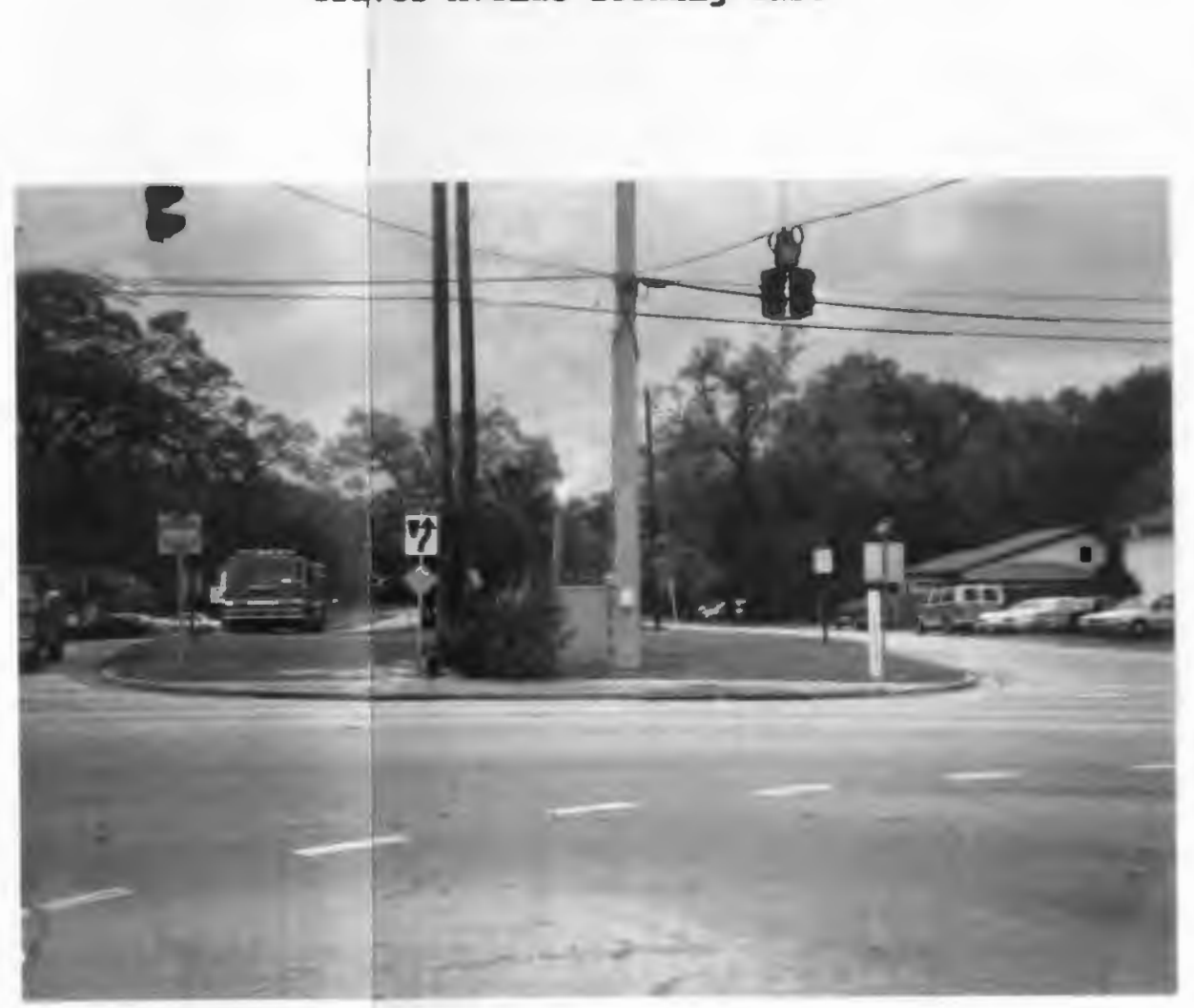

Graves Avenue looking west. 


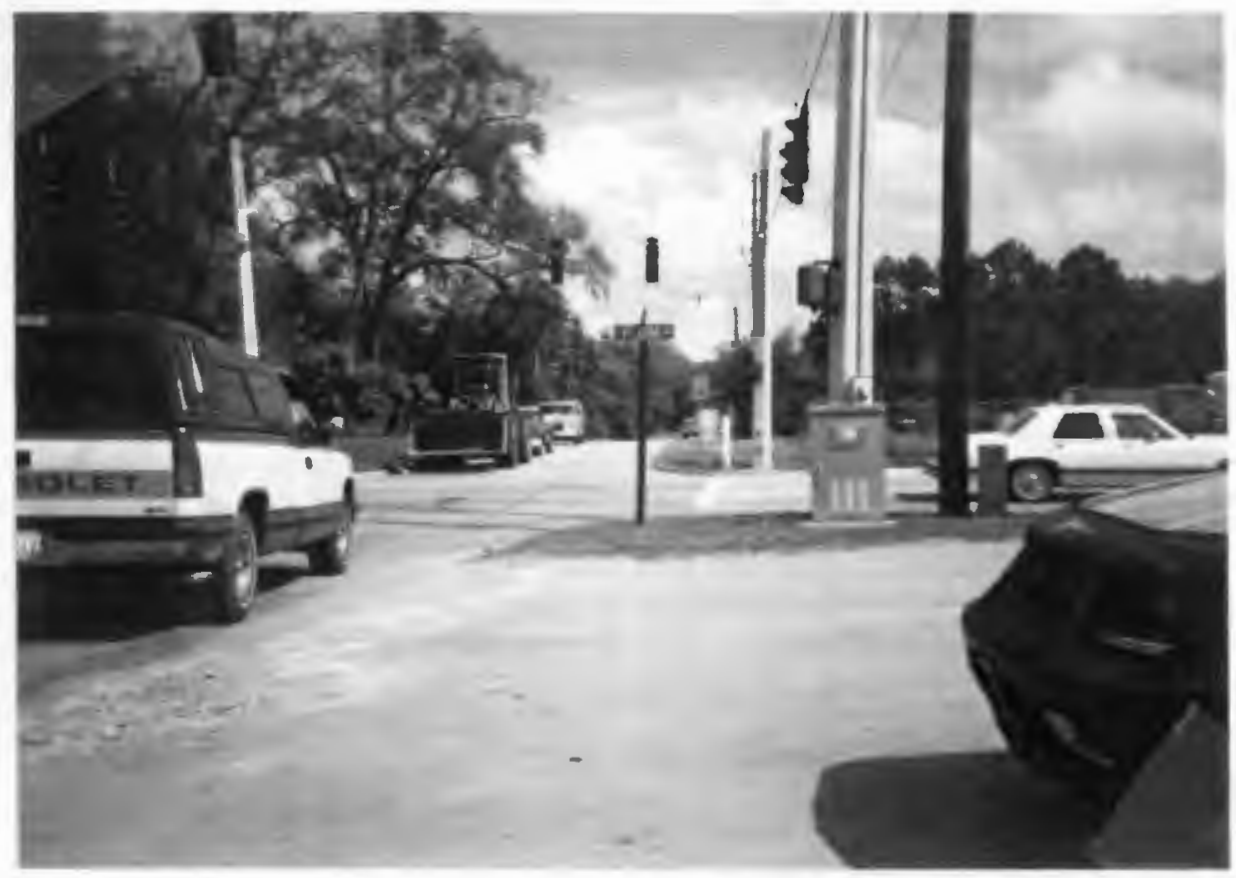

Blue Springs Avenue looking east.

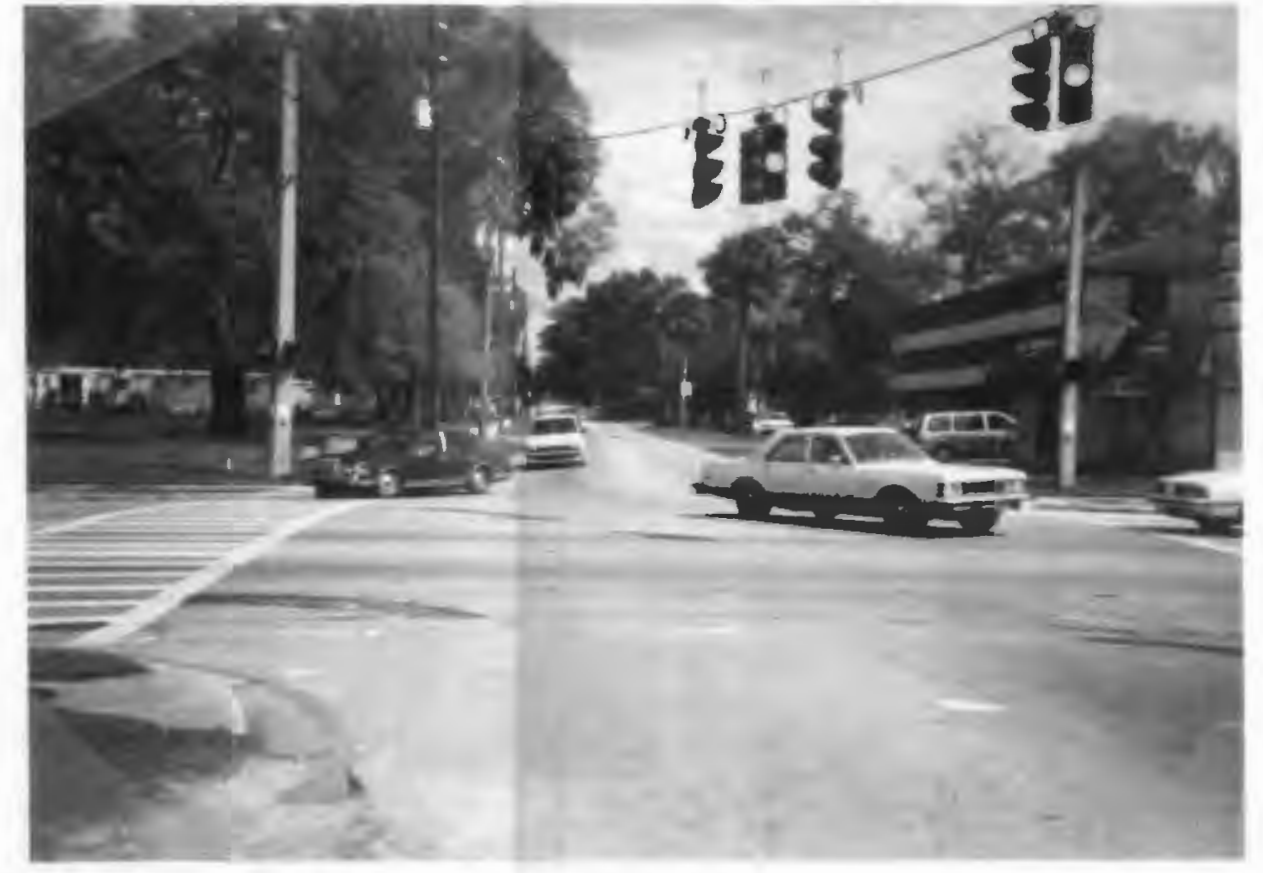

Ohio Avenue looking east.

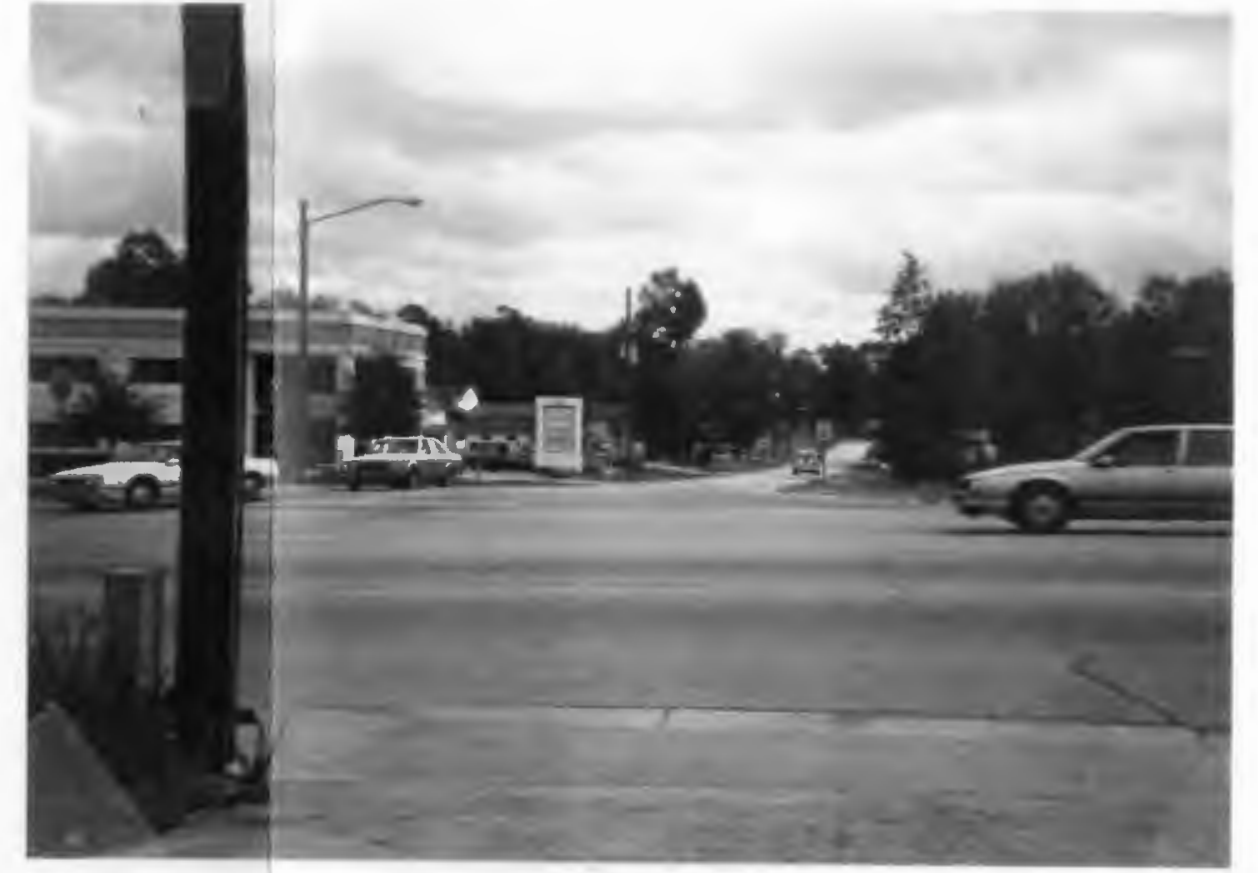

N. Industrial Drive looking east.

(Source: Photographs on all three pages were taken by the author during a site visit)

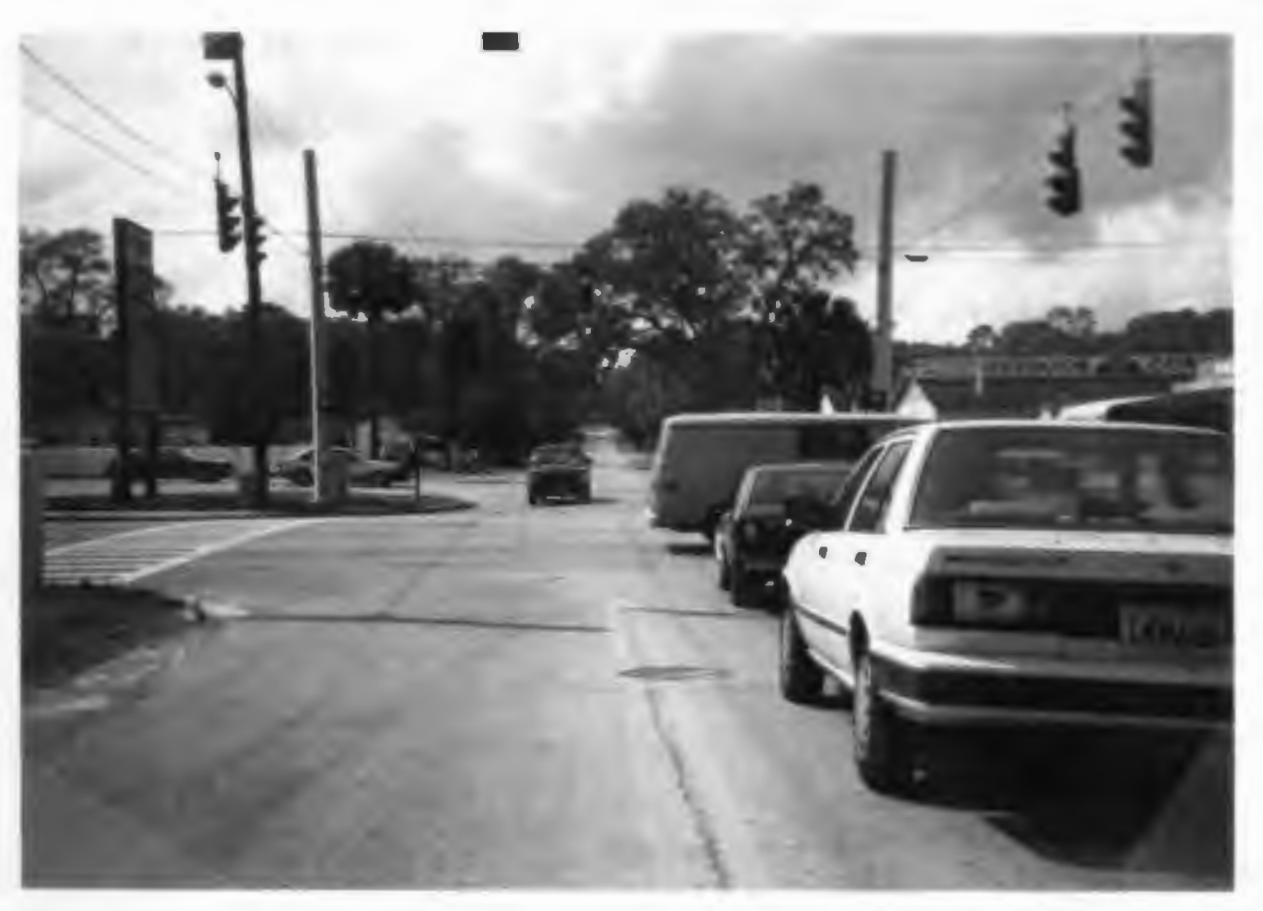

Blue Springs Avenue looking west.

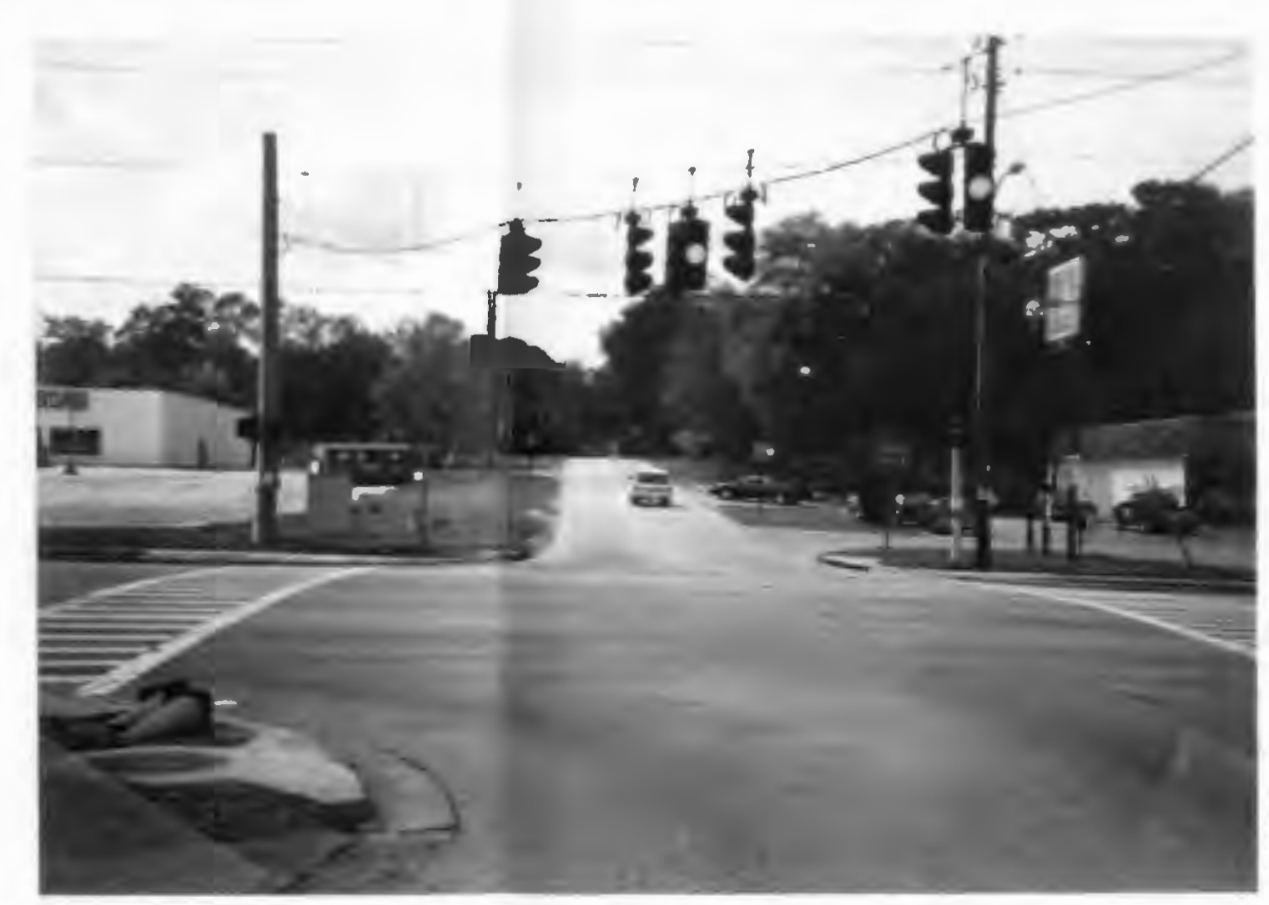

Ohio Avenue looking west. 


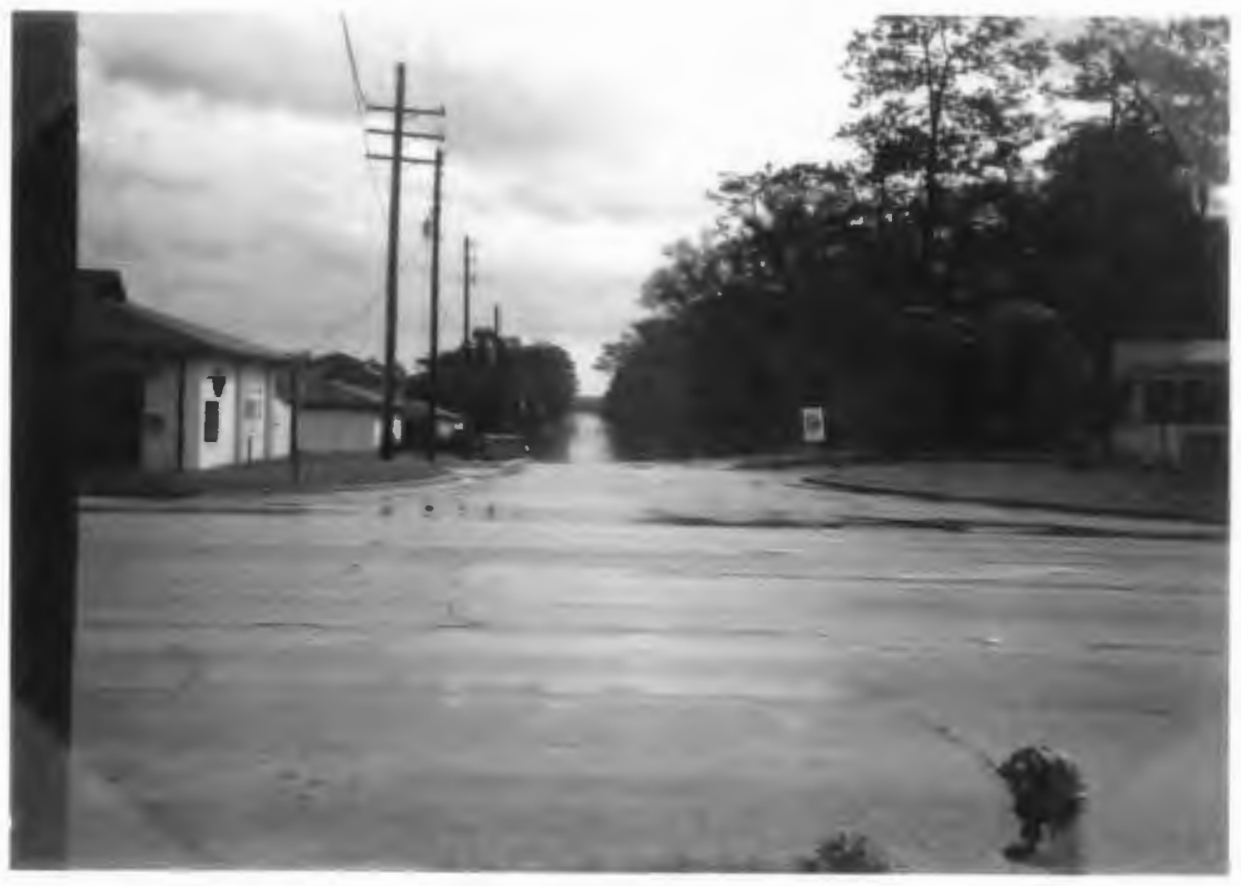

Rhode Island Avenue looking east.

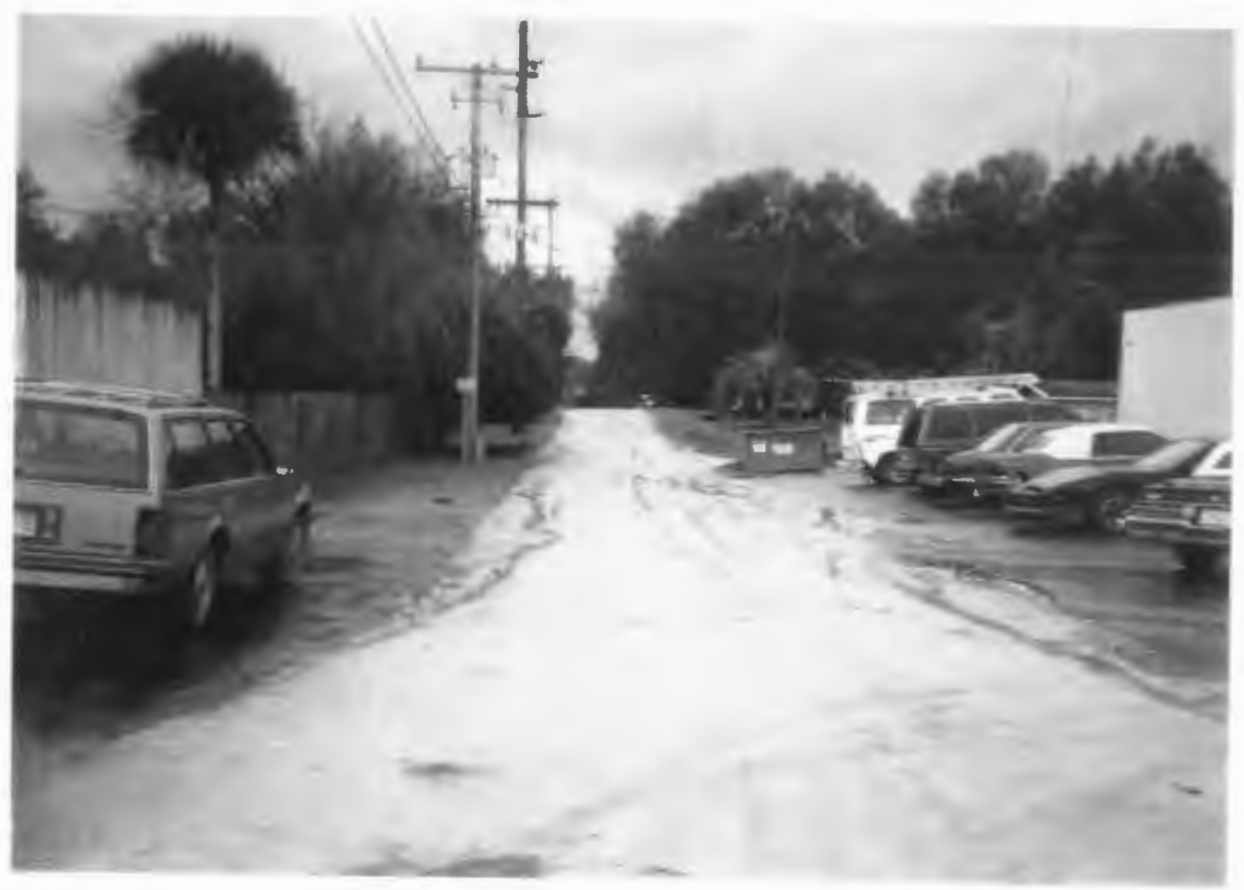

Rhode Island Arenue looking west, 
Road Conditions

The existing configuration of US Route 17-92 within the project area is approximately three miles long and 64 feet wide for most of its length. The highway is primarily 95\% straight in a northerly-southerly direction, with only a slight angling at the extreme northern and southern points. The existing width of US Route 17-92 is as follows: the bulk of the highway contains 2 six-foot on-street parking lanes located both north and south bound; an eight-foot center lane; and 4 eleven-foot travel lanes, two located both north and south bound. Only a small portion of US Route 17-92 does not have on-street parking (e.g. near the intersection of Graves). These portions of US Route 17-92 are approximately 52 feet wide. However, The Department of Transportation is preparing to eliminate the on-street parking lanes and reconfigure the existing lanes. Once the project is completed, there will be 4 thirteen-foot traffic lanes (two north and south bound), and a twelve-foot center lane. Figure 3.3 depicts the existing profile of US Route 17-92, and Figure 3.4 the proposed profile of US Route 17-92.

Mr. Milton Moritz, Orange City Director of Public Works, recently analyzed the existing road network and recommended a series of road repairs. This analysis involved visually inspecting orange city streets in regards to existing condition. As a result of this analysis, recommendations have been made in regards to whether the street in question simply 
6 feet wide (On-street Parking Lane) 6 feet wide

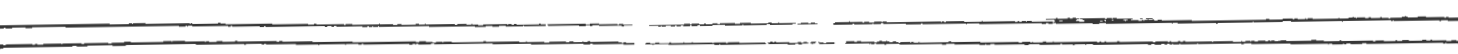

11 feet wide (Southbound Traffic) 11 feet wide

11 feet wide (Soutbbound Traffic) 11 feet wide

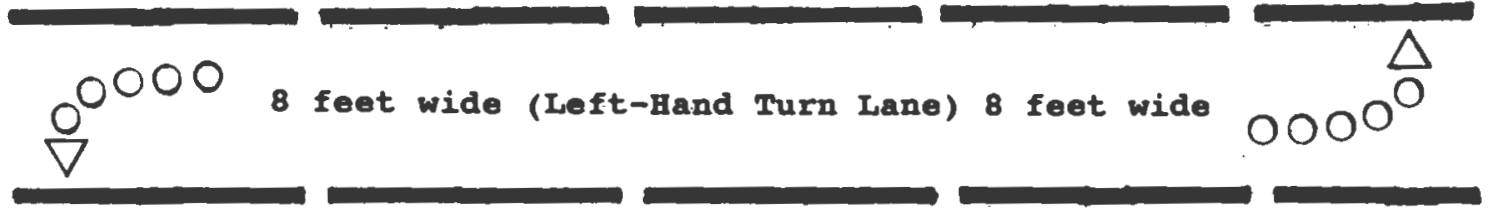

11 feet wide (Northbound Traffic) 11 feet wide

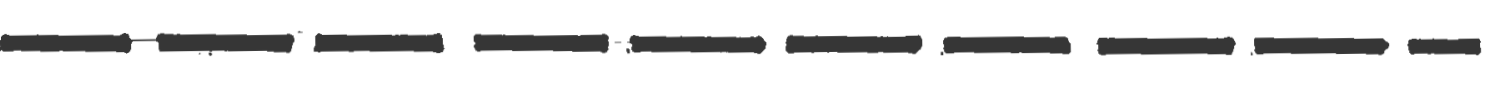

11 feet wide (Northbound Traffic) 11 feet wide

6 feet wide (On-street parking lane) 6 feet wide

U8 Route 17-92 - Existing Width Configuration

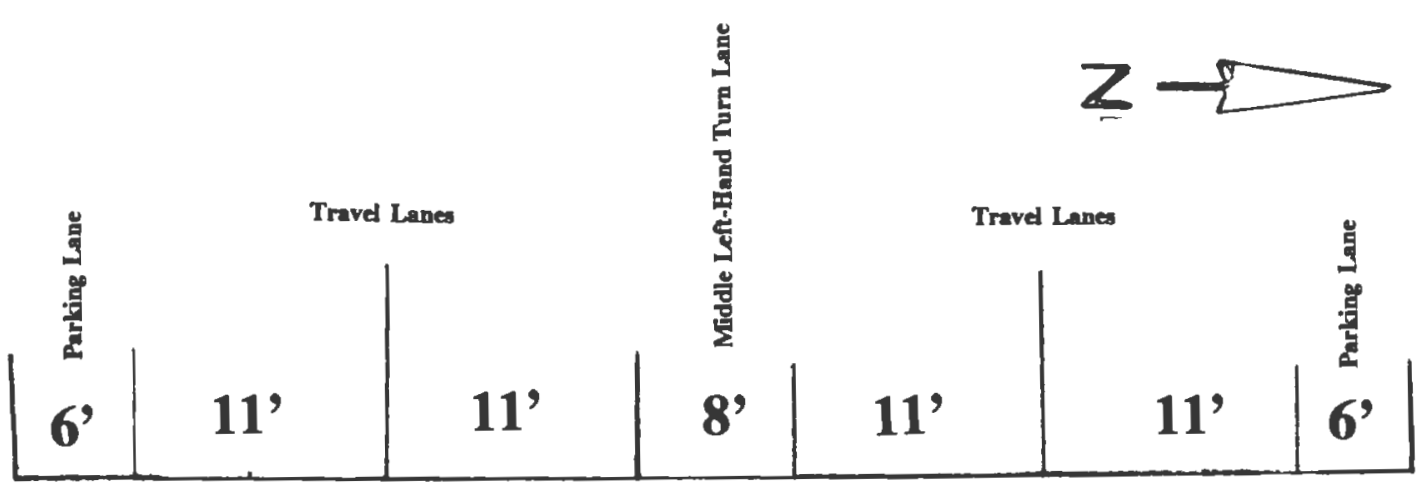

Cross sectional view of the existing width configuration 
13 feet wide (Southbound Traffic) 13 feet wide

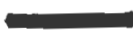

$\rightarrow$

$\rightarrow$
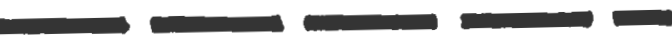

13 feet wide (Southbound Traffic) 13 feet wide

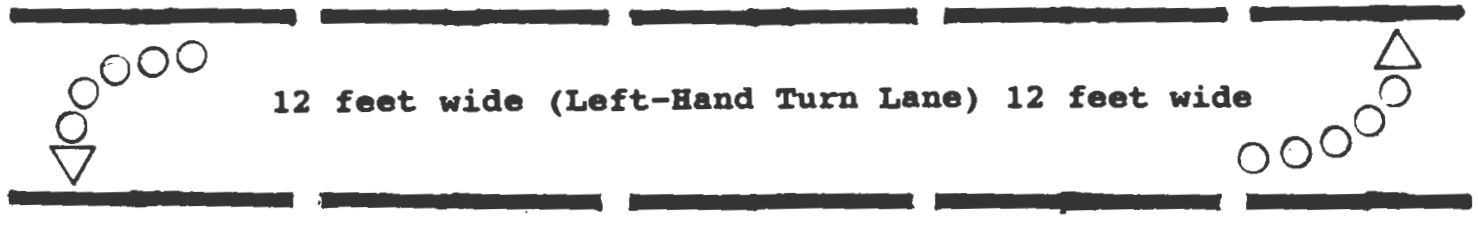

13 feet wide (Northbound Trafic) 13 feet wide

13 feet wide (Northbound Trafic) 13 feet wide

U8 Route 17-92 - Proposed Reconfiguration

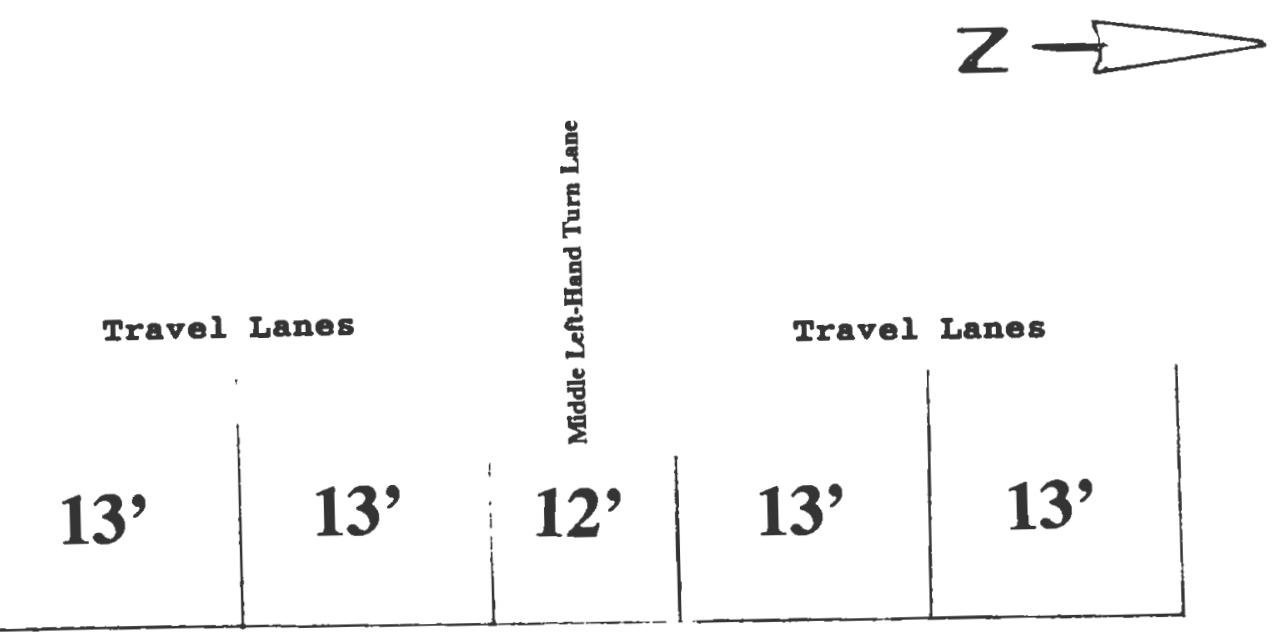

Cross sectional view of the proposed reconfiguration 
requires resurfacing or in the more extreme, new construction. The recommendations additionally include cost estimates, based upon 1993 - 1994 construction costs.

Though all of central orange City was included in Mr. Moritz's analysis, only those roads which are located within the project area are considered for purposes of this report. Table $A .5$ in the appendix, lists those roads which require repair according to Milton Moritz's recommendations and which are located within the project area. Roads are classified according to orange city and Florida Department of Transportation standards: Local, Collector or County • Repair and upkeep of Local and collector streets are the financial responsibility of the city, and county roads must be upkept and repaired by volusia county. There are four sections of streets which are classified as county roads.

These four street sections are located within the project area, and thus, have been included in the overall analysis. In order to arrive at a comprehensive cost estimate, repairs were calculated at $\$ 60$ per foot. ${ }^{4}$ These costs are not, however, included in the total repair expenditure due to their county designation.

In total, there are 82 street sections within the project area which require repair of one form or another. This includes 63 sections classified as Local streets, 15 sections classified as collectors and the previously mentioned four County street sections. Repairs include 51 street sections 
requiring resurfacing and 27 street sections requiring new construction. Though listed as requiring repairs, the repair status of the County street sections were not stipulated, and thus, are unknown.

Repair costs range from a low of $\$ 12,250$ for the resurfacing of some small street sections, to a high of $\$ 356,400$ for the new construction of Leavitt Avenue, an outer project area border. The total cost for repairing all Local and collector streets requiring resurfacing and/or new construction within the project area, is estimated to be $\$ 5,286,030$. The total cost to the county and state for repairs of the four sections of county designated roads, is estimated to be $\$ 930,000$. Figure 3.5 illustrates those streets located within the project area which are in need of repair.

\section{Alternative Routes}

The West Volusia Beltline, which has been proposed as early as the 1970s, is about to become a reality (Figure 3.6). During the past two decades no construction took place due to a lack of funding, however, such is not a concern any longer. 5 The Beltline will begin at Saxon Boulevard to the south and continue till it meets and turns into Kentucky Avenue. The Beltline will then proceed as an extension of Kentucky Avenue and continue north till it intersects with Us Route 472, before continuing on till its connection with and completion 


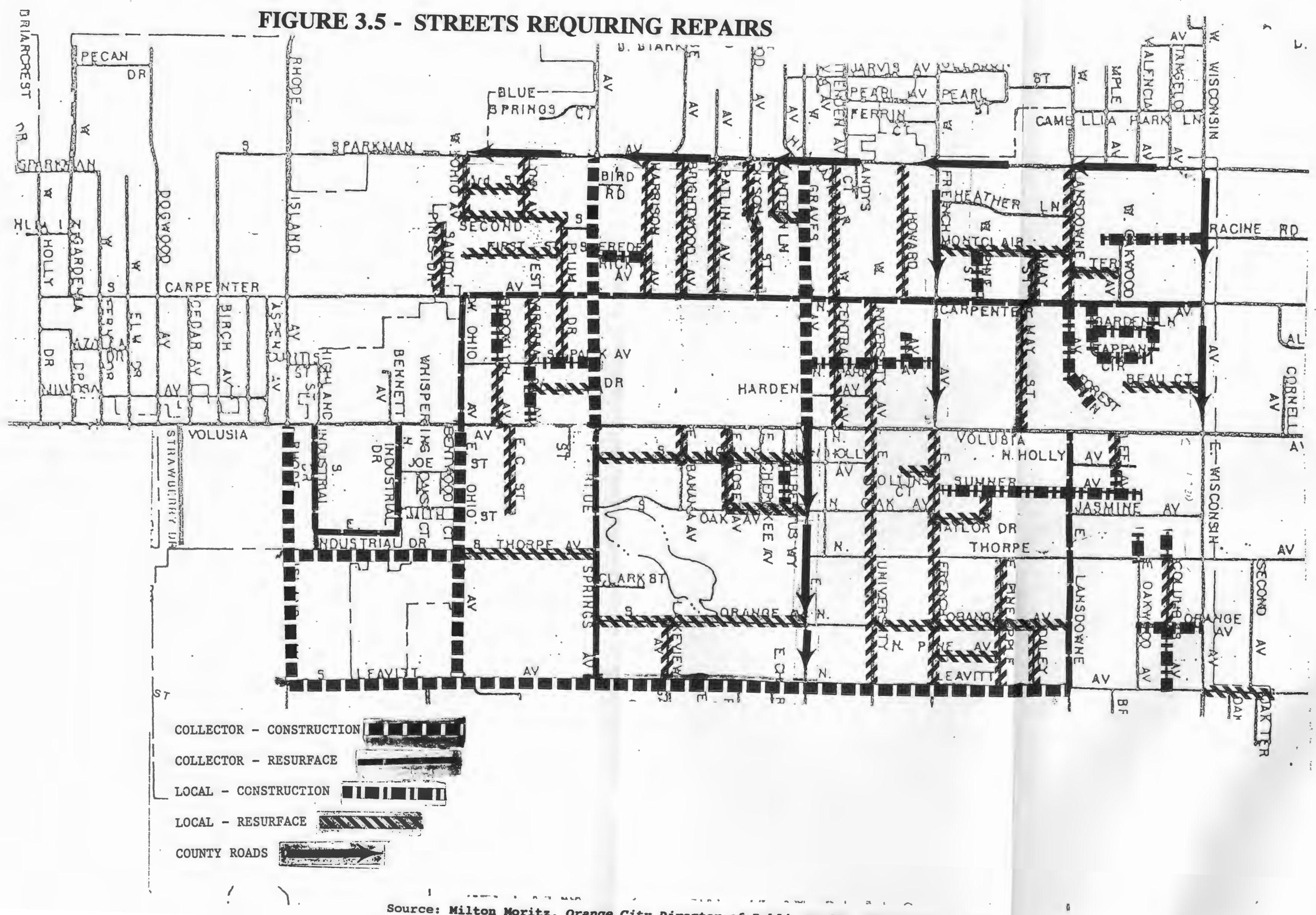

Source: Milton Moritz, Orange City Director of Publig Worke, orryge City, 
at Kepler Road. The entire Beltline will be eight miles long and cost approximately 14 million. ${ }^{6}$ The completion of the Beltline will aid in diverting traffic off of US Route 17-92. Specifically, that portion of traffic which is travelling to the commercial malls located on Enterprise Road as well as DeBary. Thereby, allowing US Route 17-92 to cater to those persons who desire to utilize the businesses located there. The only concern stemming from this proposal is the limited access restrictions which are currently in place. ${ }^{7}$ If more constraints are not established, then the numerous driveways and curbcuts which currently exist along Us Route 17-92 could occur again. This would shatter the sole purpose of the Beltline, namely as a bypass to avoid the congestion on US Route 17-92. Another project which has been recently completed, and thus, aided in alleviating some of the traffic stress, is the I-4 Interchange off of Saxon Boulevard. By constructing an additional interchange, drivers do not have to travel to the interchange located off of US Route 472 by way of US Route 17-92.

\section{O8 ROUTE 17-92 CORRIDOR ANALY8I8}

Commercial Businesses

US Route 17-92 has become a prime example of what is referred to as a strip commercial corridor. There are approximately 178 businesses (including professional and nonprofessional) along US Route 17-92 within the project area. 
Figure 3.6

Proposed West Volusia Beltline

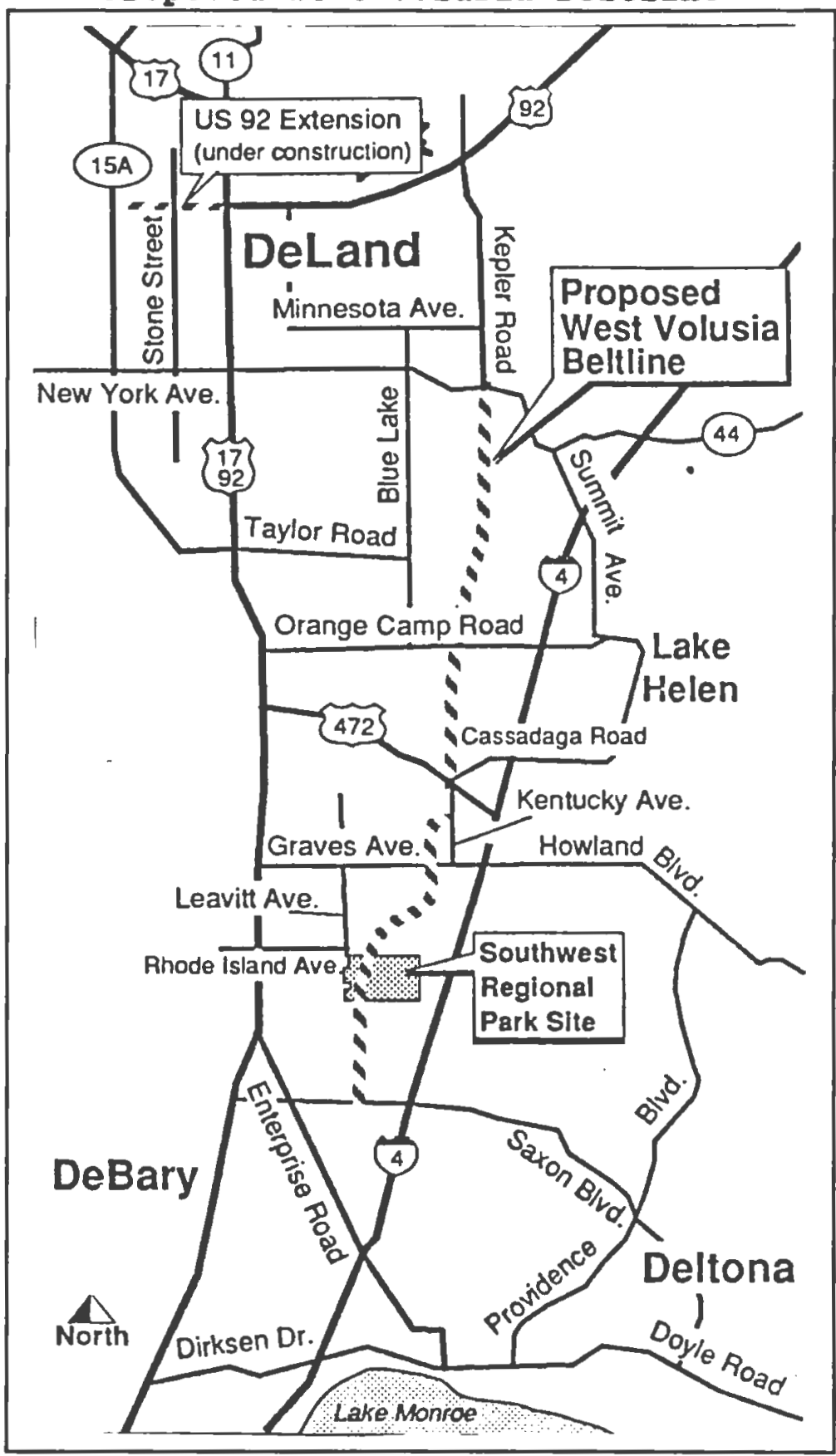

(Source: Cindy stefanski, "New Highways Need Access Restrictions," The Volusian, $21 \mathrm{July}$ 1991, Section: Viewpoint) 
There are all sorts of businesses on US Route 17-92, ranging from two dance studios to three motels to ten

furniture/antique dealers. The variety is endless, and the area is not at a loss for any product. The tremendous commercial growth on Enterprise Road has aided in filling any gaps which may have precluded the area from becoming self sufficient. However, along with this concept of self sufficiency, problems have also evolved. Such problems as poorly placed parking areas, limited landscaping, lack of attention to architecture and haphazard signage.

Table $A .6$ in the appendix, specifically outlines all existing businesses by category of occupation in which they are engaged in. The information included in this list is drawn from the business survey data collected between February 21 - March 2, 1994. Table A.6 indicates number of businesses by category, whether they participated in the business survey or not and location (both north and south bound) in regards to primary US Route 17-92 bisectors.

Most of the businesses within the project area, are located between Rhode Island Avenue and Enterprise Road. The reason for this is that the stretch of highway between these two points is lengthy and there are several small commercial centers in which a variety of professional businesses are located within. A small quantity of the businesses located between these two points are located in Volusia County outside the city limits. However, they were not delineated because 
all businesses must be considered in regards to the upgrade and improvement of US Route 17-92. The shortest stretch of highway is between Blue springs and Ohio Avenue. However, there are still 22 businesses located between these two points. The fewest number of businesses are located between French and Graves Avenue, because of limited distance and spacing between businesses.

In addition to the 178 existing businesses, there are several vacant properties of various sizes and several vacant lots. Furthermore, there is one church, the orange city Library and a historical structure (former Deyarman square) which is currently being used for adult services. Scotty's, a construction and lumber supplier, is located at the intersection of Enterprise Road and US Route 17-92, and thus, was included as a highway business. However, they will soon be moving onto Enterprise Road, thereby, creating an additional vacancy.

Building Form, Massing and Architecture

Several of the buildings located along US Route 17-92 within the project area were constructed over several decades ago, and have since been rehabilitated and reused (e.g. Webster Medical Clinic) Illustration 3.3 displays the Medical Clinic as it appeared in the 1920 s when it was originally a bank. On the other hand, several other buildings have been reused, but not necessarily rehabilitated (e.g. Hasit House 
Used Furniture) . Illustration 3.4 displays the used furniture store as it appears today.

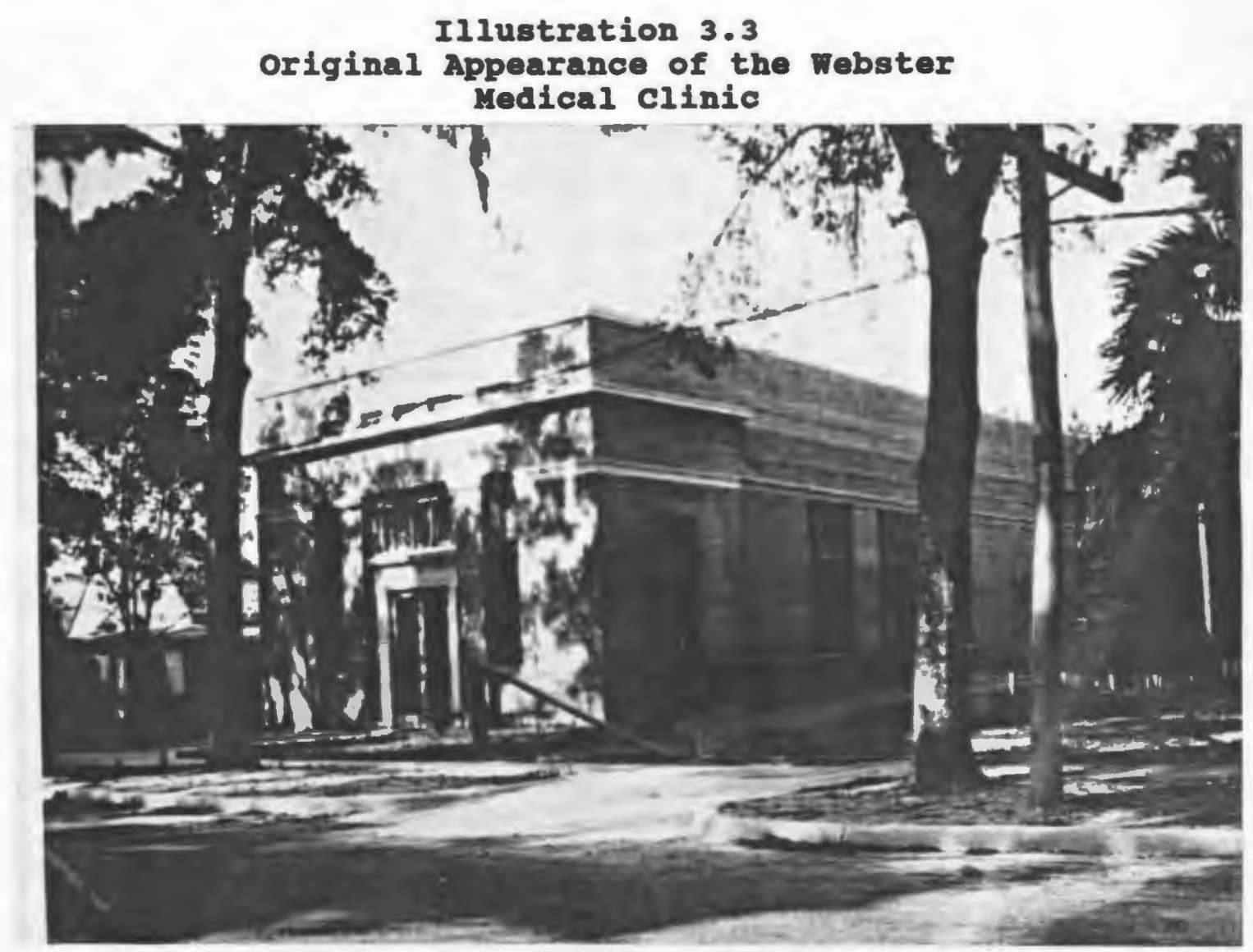

(Source: Carol Goose, Local Orange City Historian)

The bulk of existing buildings are fairly new, and thus, have little intrinsic architectural value. The only two buildings which have historical value include the former Deyarman Hotel which is now used for adult services (Illustration 3.5), and the Emily Dickerson Public Library (Illustration 3.6 ).

Due to limited zoning Regulations in the past and a current lack of proper enforcement, many buildings are constructed in an unsightly manner (e.g. the Midas shop which 


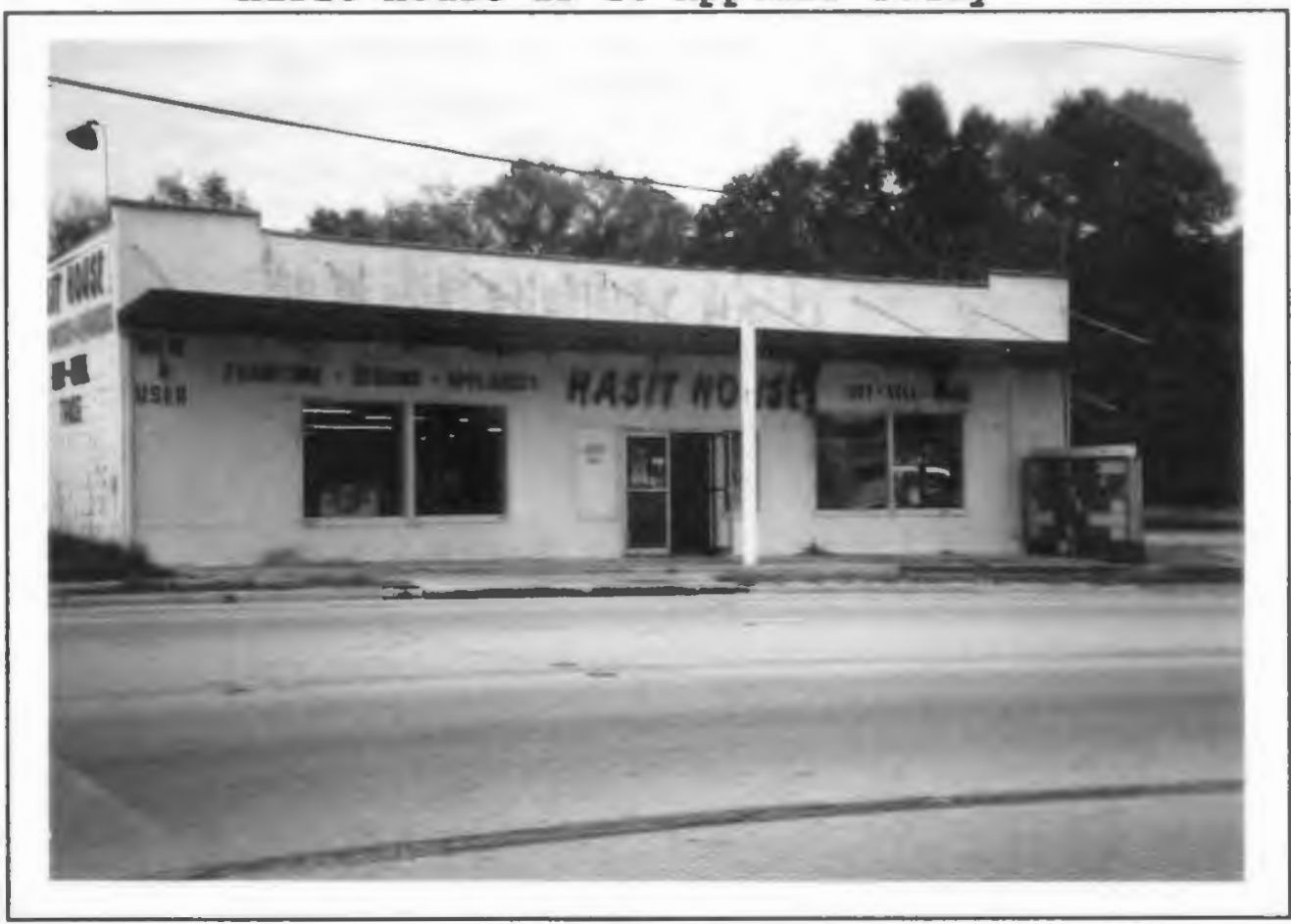

(Source: Photograph taken by the author during a site visit)

is fabricated with tin, Illustration 3.7). Additionally, several of the businesses which are architecturally unappealing and manage their business in an odd manner are located in Volusia county, and thus, are not subjugated to Orange City Zoning ordinances (e.g. Carl and Bob's Auto Repair which conduct its auto repairs outside under a wooden and tin canopy for all motorists to see, Illustration 3.8).

Buildings are unevenly spaced from one another due to variations in lot size, and therefore, there are periodic voids. In other words there is no set pattern or arrangement. Matters are further complicated by the large frontage oriented 


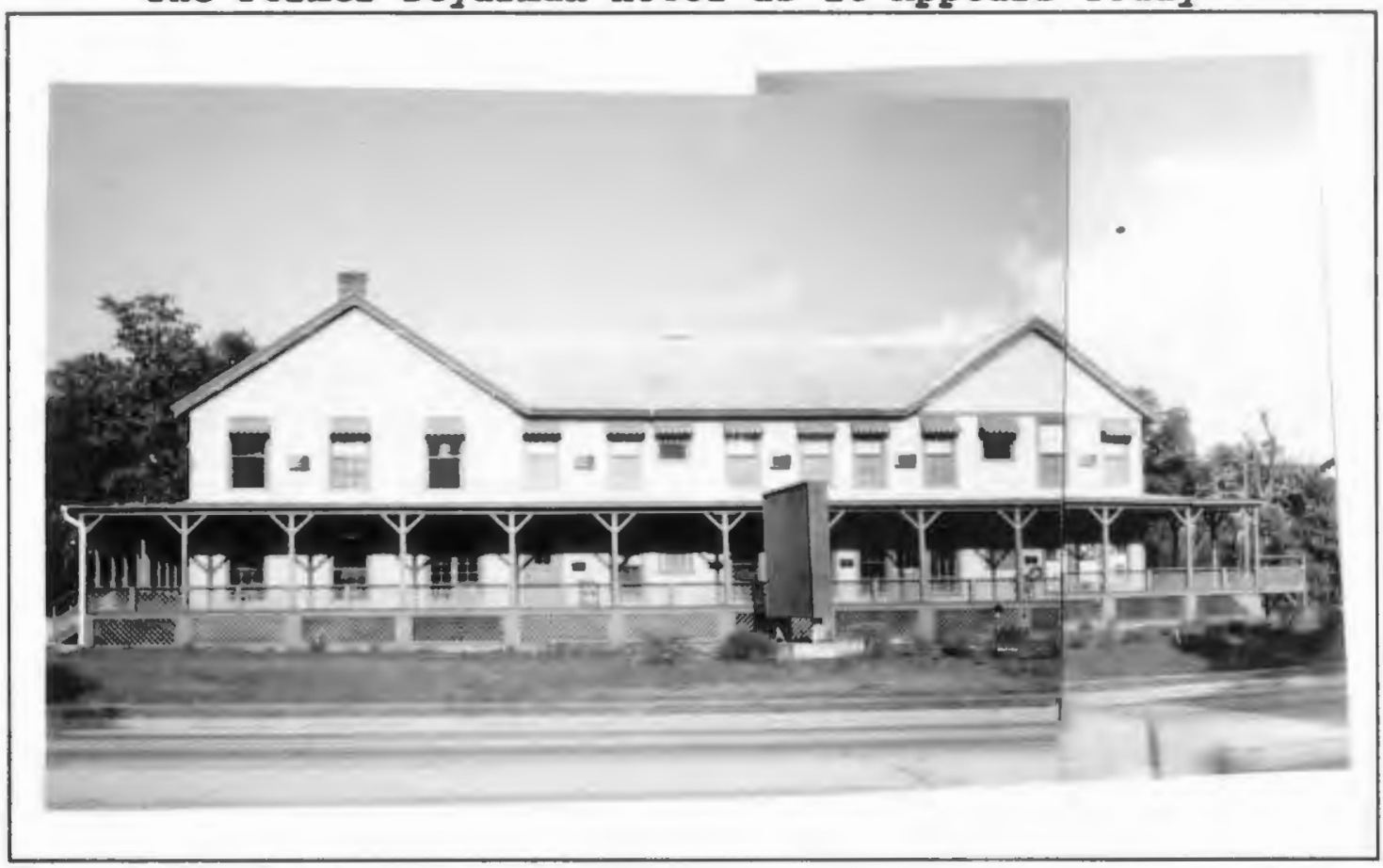

(Source: Photograph taken by the author during a site visit)

parking areas which tend to create unappealing and unenhancing voids. Such voids include the parking lots of scottys (Illustration 3.9), Lowes and Dave's Discount Furniture, which is going out of business, and thus, was not included in the business analysis.

on the other hand, many sections are overly congested with no set arrangement nor even a streetscape appearance. Several businesses will encroach upon the right-of-way (be located directly upon city sidewalks), while adjacent businesses remain somewhat setback. Such buildings themes will tend to see-saw as described for some distance. The reasons for such architectural disorientation, is 
Illustration 3.6

The Emily Dickerson Library as it Appears Today

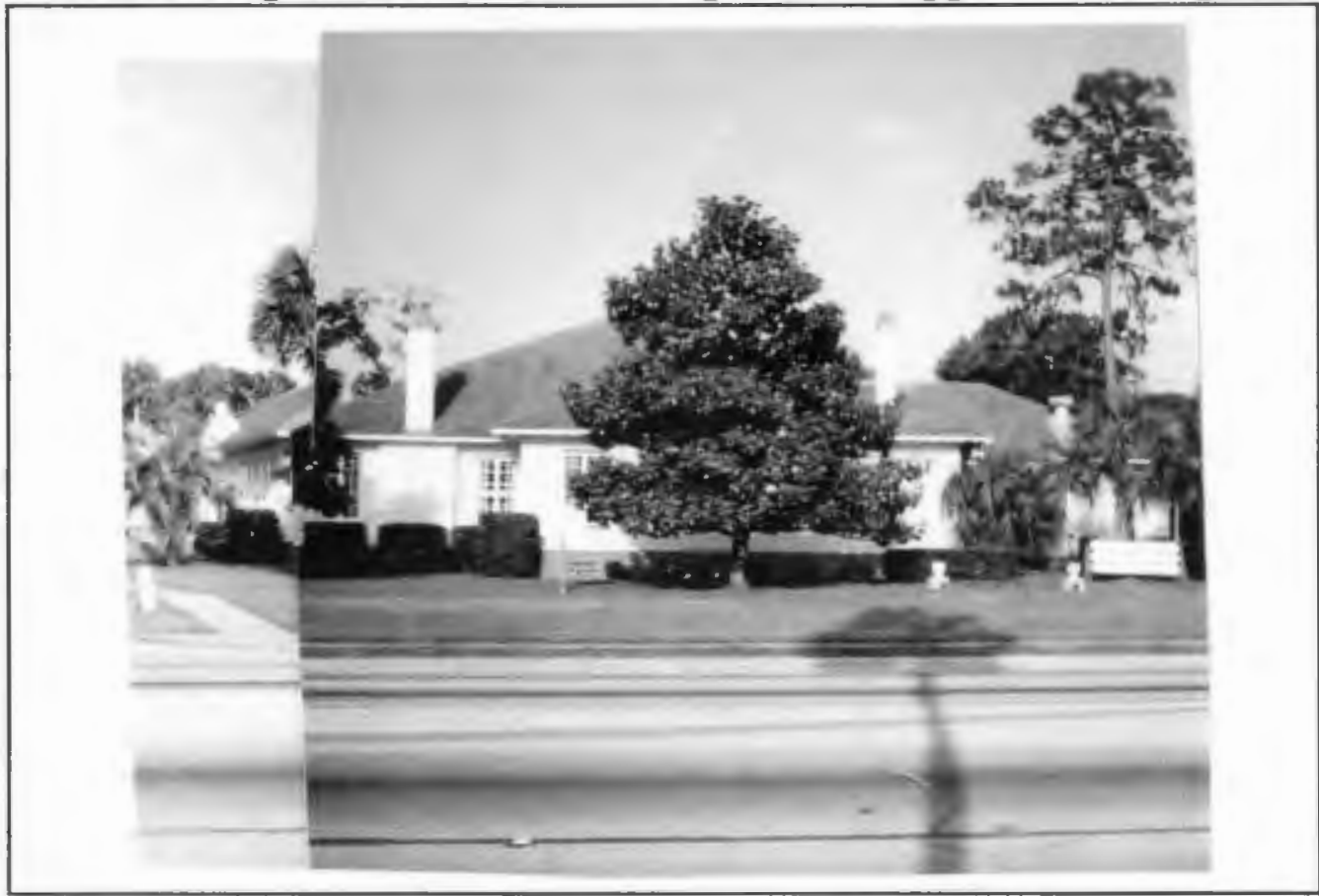

(Source: Photograph taken by the author during a site visit)

because of the time frame in which the various buildings were constructed and the lack of concern of business owners due to the "situated-upon-a-highway" mentality. There is one significant node located just slightly east of US Route 17-92 on East Graves Avenue. The Orange City Town Hall comprises this node, and it is valuable in both an architectural as well as historical sense (Illustration 3.10). The Town Hall was recently rededicated on its one hundredth year anniversary. The Town Hall has undergone renovations to make room for a growing staff, however, it still retains its rich history and architectural look. The original bell is still located atop the Town Hall and can be heard on a regular basis. 
Illustration 3.7

The Midas shop Fabricated of Tin

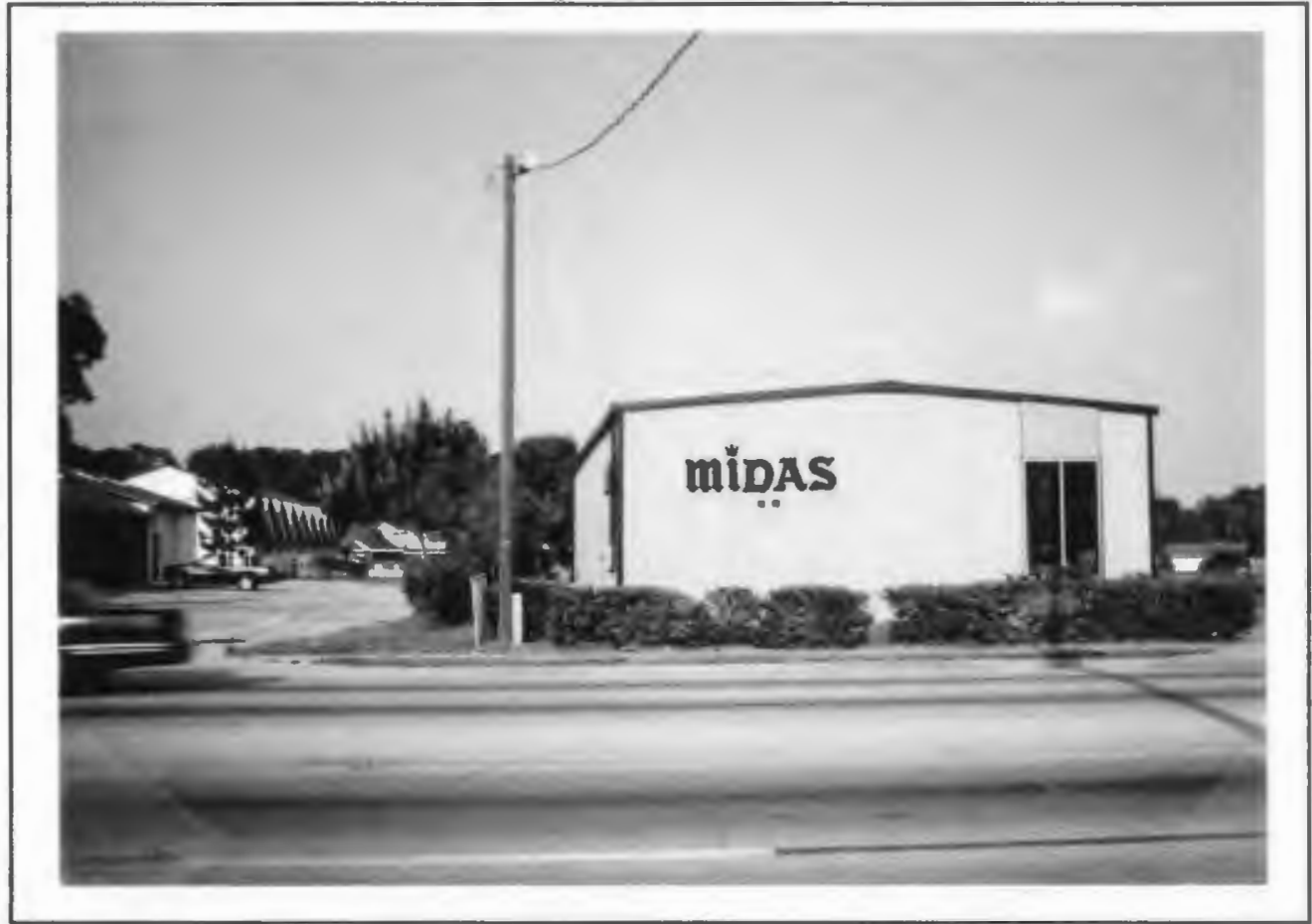

Illustration 3.8

Carl and Bob's Auto Repair - Repairs Done Outdoors

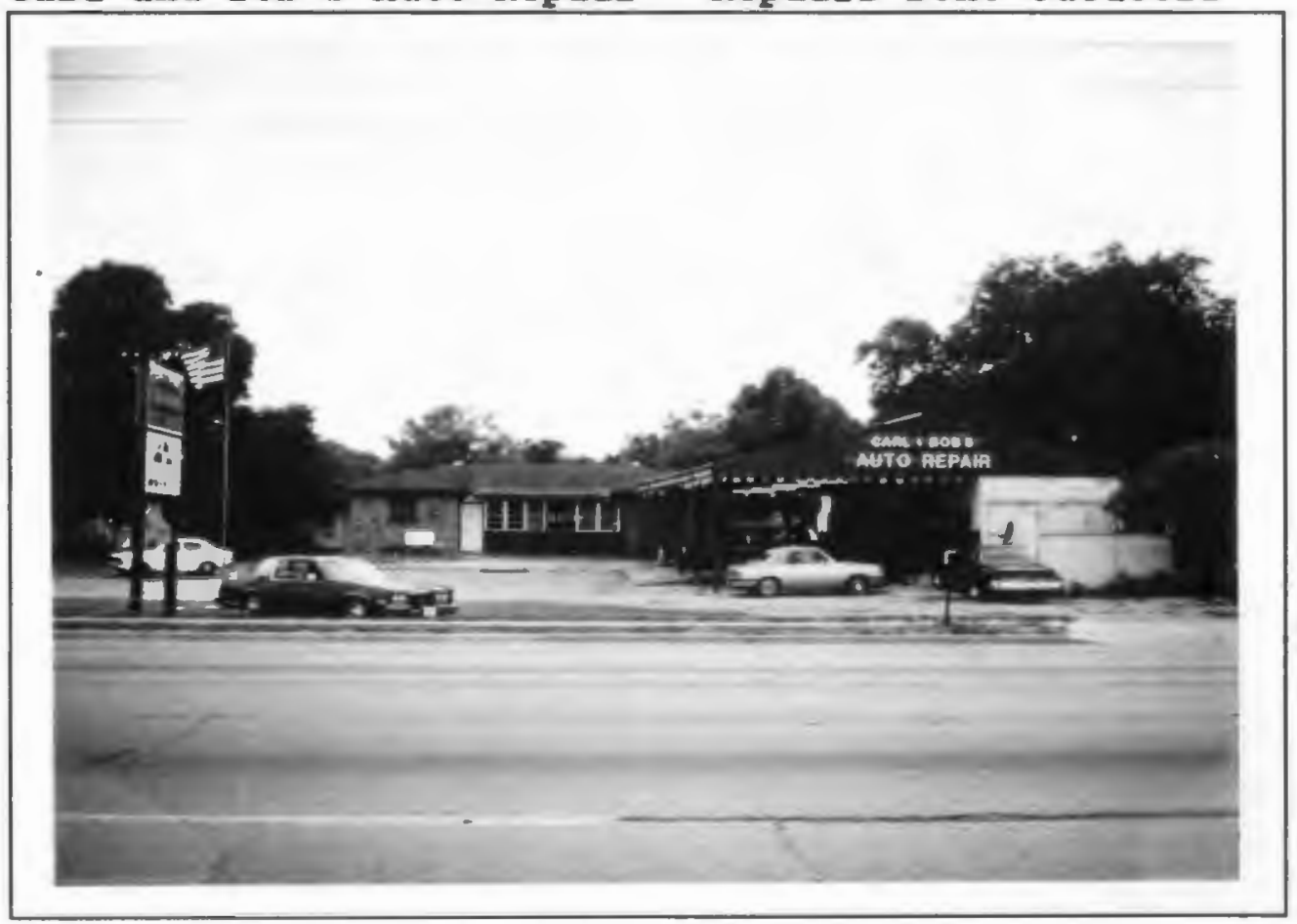

(Source: Photographs taken by the author during a site visit) 
Illustration 3.9

scotty's Vast Frontage Oriented Parking Lot

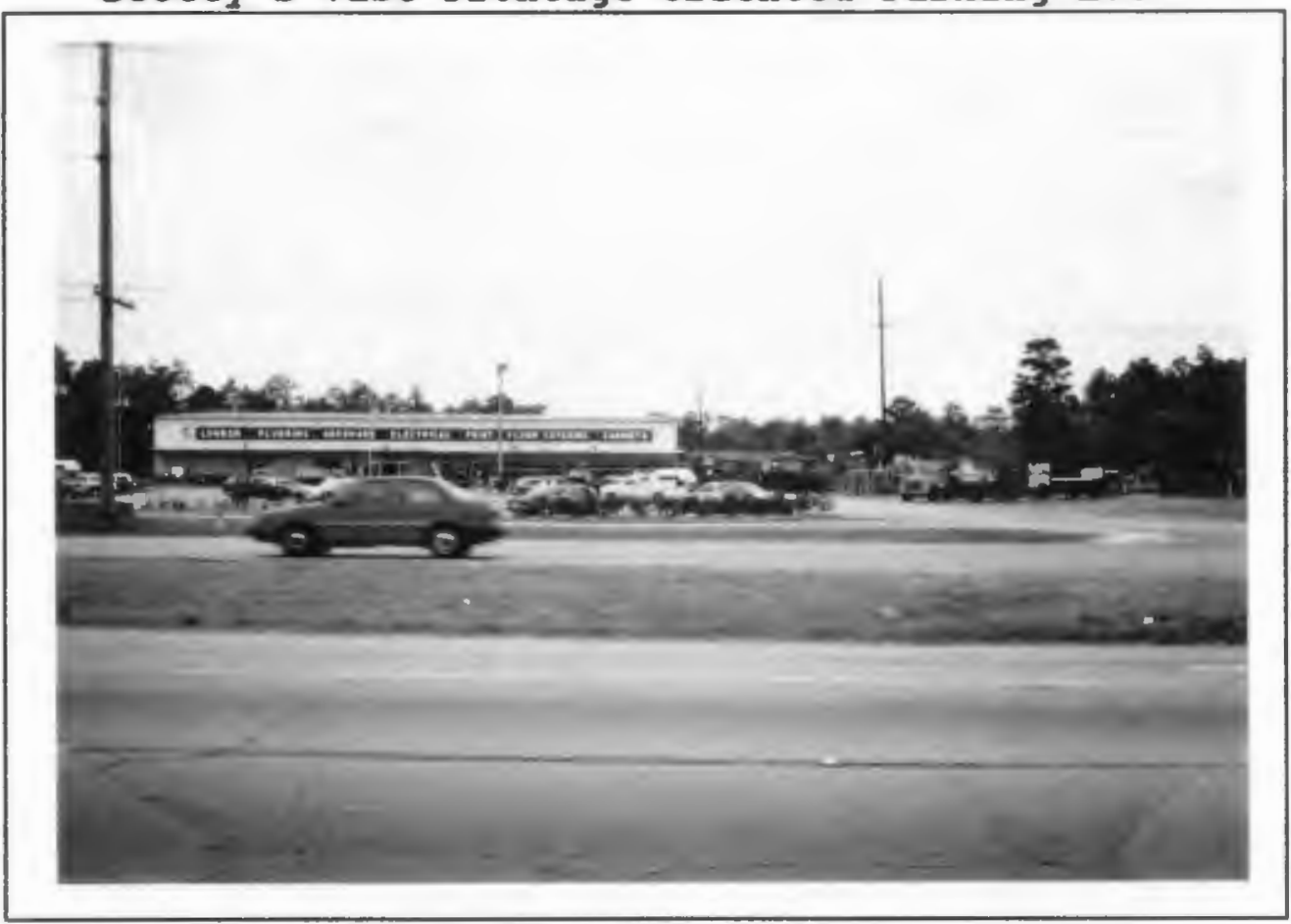

(Source: Photograph vaken by the author during a site visil)

Illustration 3.10

orange City Town Hall, Located on East Graves Avenue

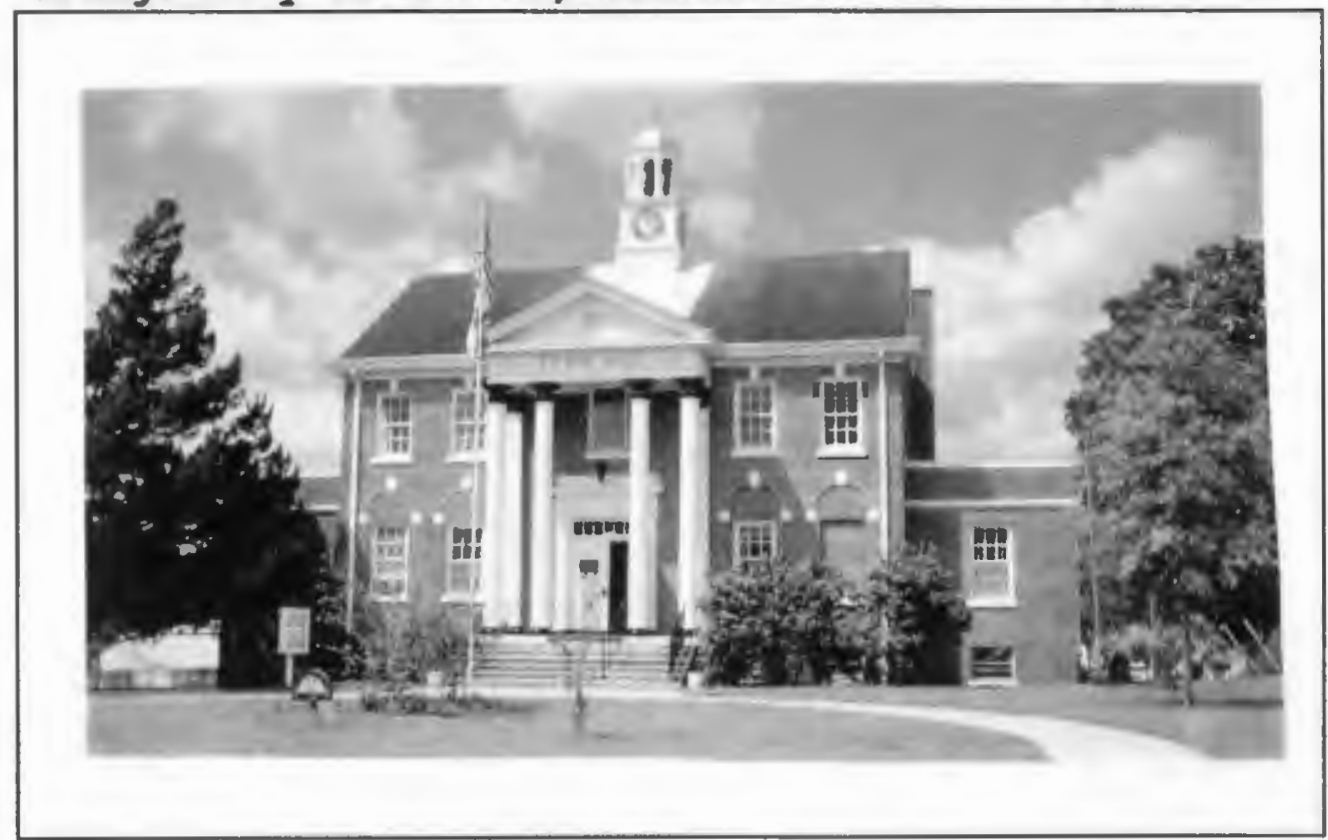

(Source: Greater Chamber of Commerce, "Guide 10 Orange City Florida," Orange City, Florida: Official Publication of the Greater Orange City Area Chamber of Commerce, 1992) 
Private and Public Signage

Each and every commercial business along Us Route 17-92 has a sign of one form or another. Such signs consist of typical pole (PI) or wall sign, or other types. The following list is an all inclusive array of those type of signs found within the project area: Changeable copy (CC), in which letters may be removed at will (e.g. gasoline prices); Marquee (Mq) in which the sign extends from a wall or vertical surface; Monument (Mt) in which a sign may consist of stone or be placed in a landscaped environment; Roof (Rf) which is similar to a wall sign, except it is attached or permanently affixed to the top of a structure; Hanging ( $\mathrm{Hg}$ ) in which a sign is suspended from a pole or other object (e.g. some American Flags); Banner - orange city only allows such signs on a temporary basis; and, Portable (Pt) in which a vehicle or some other moveable object is used as advertising - though allowed, Orange city refrains the usage of vehicles for advertising means.

Table A.7 in the appendix, was prepared in 1991 when the City revised its sign ordinance. Table $A .7$ presents the following information; name of business, address, whether located in the city or county (marked with an "X"), type of sign and specific information relating to the measurements of the various signs found on the premises. These measurements include: overall sign height, including height of pole or other object on which the sign is attached; height of all 
space occupying sign(s); dimensions of all attached sign(s); dimensions of all wall sign(s); and, whether or not the side and front setbacks are violated. Table $A .7$ also indicates quantity and percentage of city signs which are conforming (under or equal to 18 feet as stipulated in the newly revised sign ordinance) as well as non-conforming. county signs are additionally scrutinized as to conformity. However, they are not bound by city ordinances, and therefore, these figures are just for informational purposes.

Table $A .7$ does not contain all the businesses located along US Route 17-92. However, approximately $65 \%$ to $75 \%$ are accounted for. Table A.7 lists 84 different addresses, however, the number of businesses are actually higher because 10 of these addresses contain several businesses. These include the 951 Building, 400 Building, Blue Springs Plaza, Orange City Executive Center, Mosca Plaza, 3 Season's Plaza, Blue Springs Center, Engineering Complex, 4 Townes Executive Center and Pooser Park Plaza.

From the sampling of existing signs listed in Table $A .7$, 33 signs (32\%) are currently non-conforming by the new sign ordinance maximum allowable height requirement of sixteen feet. The reason why so many signs are non-conforming is due to a lack of tough legislation, (e.g. strict amortization policy), and an inability to enforce that legislation which does exist. Illustrations 3.11 and 3.12 are two examples of the type of poor signage which can be readily found on US 
Route 17-92. Illustrations 3.13 and 3.14 are two examples of aesthetically enhancing signage which is sporadically located throughout US Route 17-92. Orange City has several signs which identify the City limits. The reason for so many is due to the odd configuration of the city. Most of the signs are the typical green colored municipal type. However, the sign located at the northerly entrance of Orange city on US Route 17-92, is a conglomeration of information attached to a wire mesh gate. A site which is not particularly attractive, nor useful as a promotional tool (see Illustration 3.15). The southerly entrance of Orange City on US Route 17-92, has no

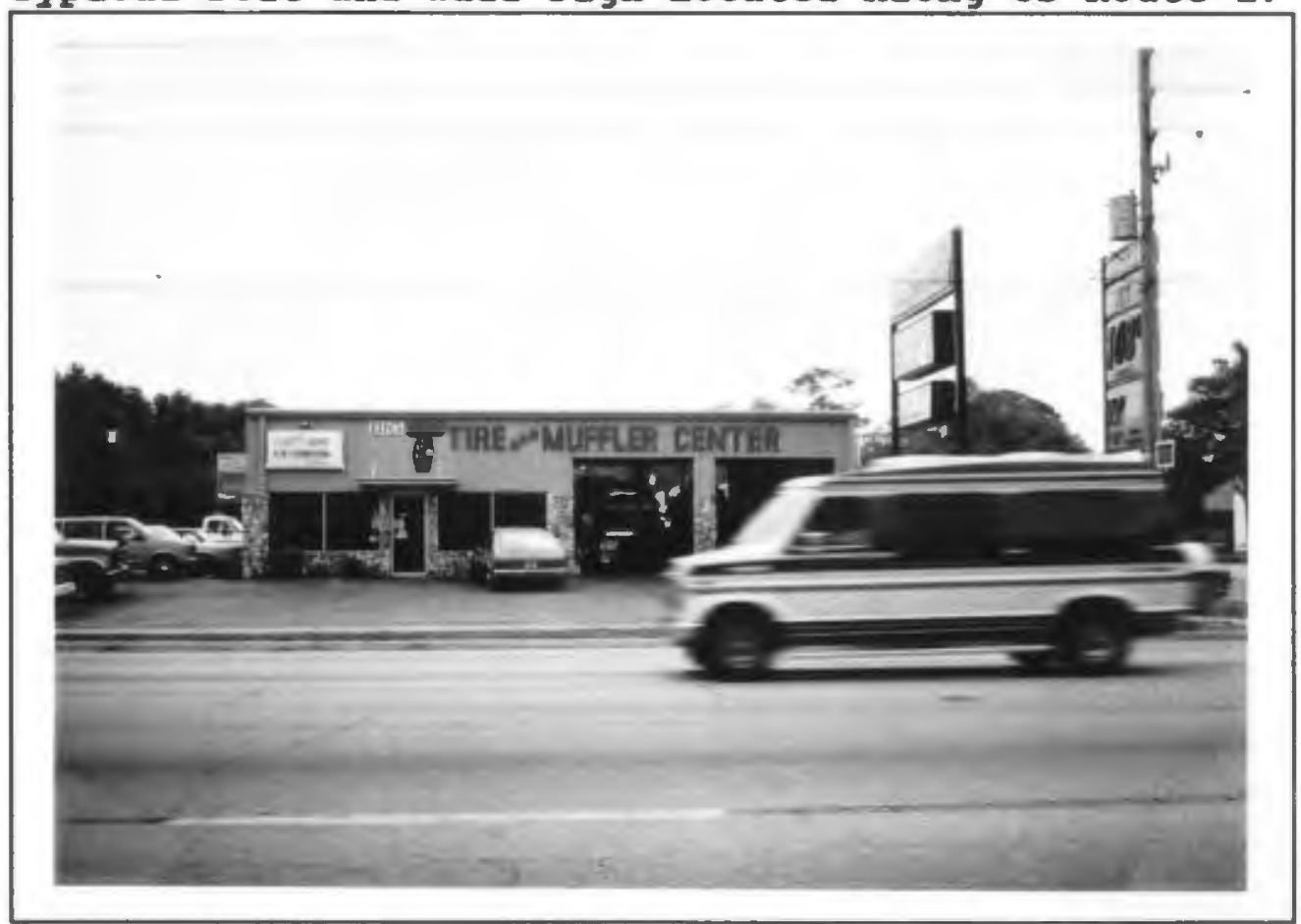

(Source: Photograph taken by the author during a site visit) 


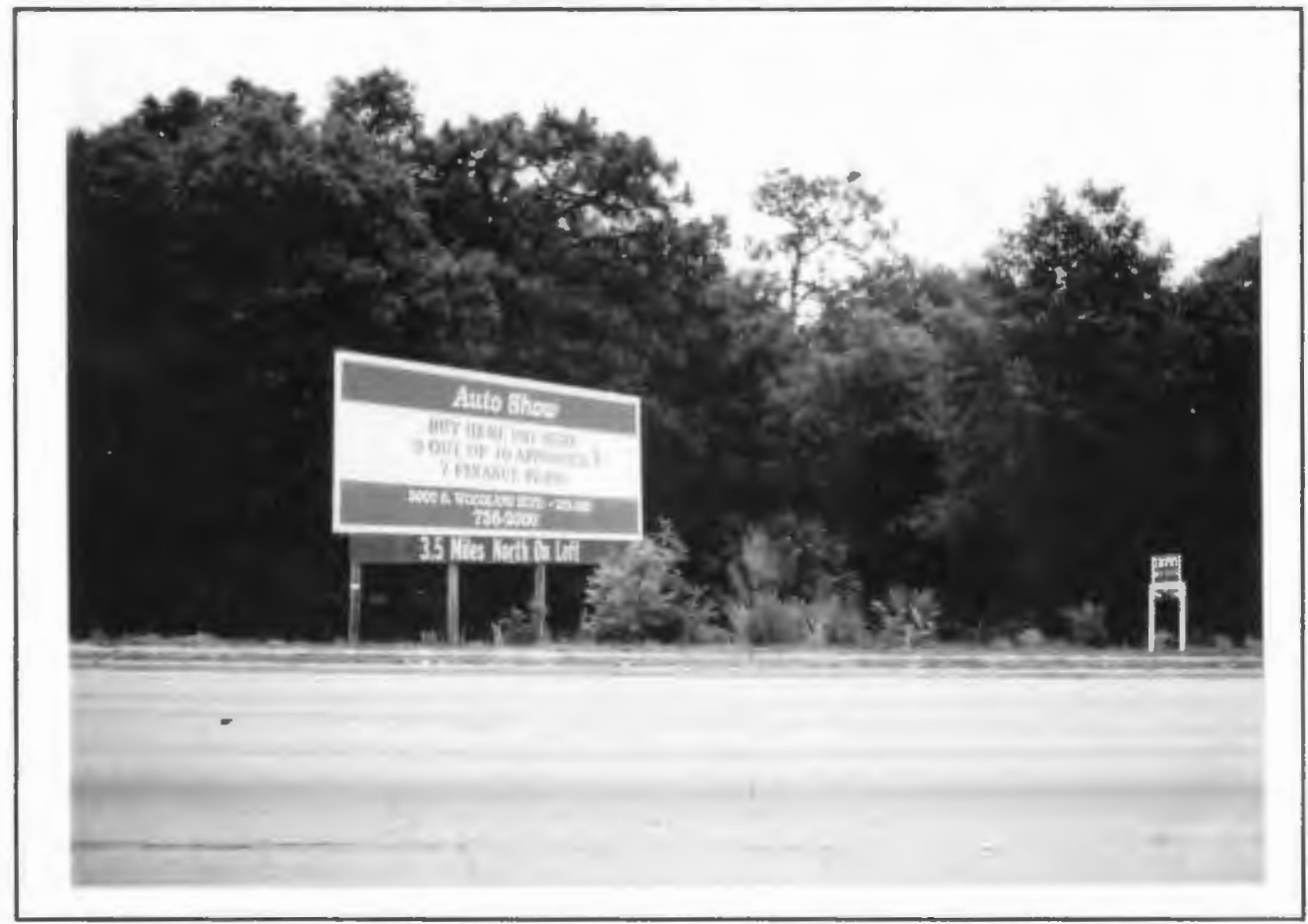

(Source: Photograph taken by the author during a site visit)

entrance sign to speak of. Therefore, both ends of 17-92 are in need of city enhancing gateways in order to better promote the area.

Parking

At the present time, on-street parking is allowed along a large portion of US Route 17-92. Those sections of the highway (both north and south bound) in which parking is allowed, are indicated by a single white striped line. The Department of Transportation is preparing to eliminate all onstreet parking as early as May 1994. Therefore, this source of parking for business purposes will not be considered in 
Ilustration 3.13

Limited Example of a Mell Landscaped Commercial sign

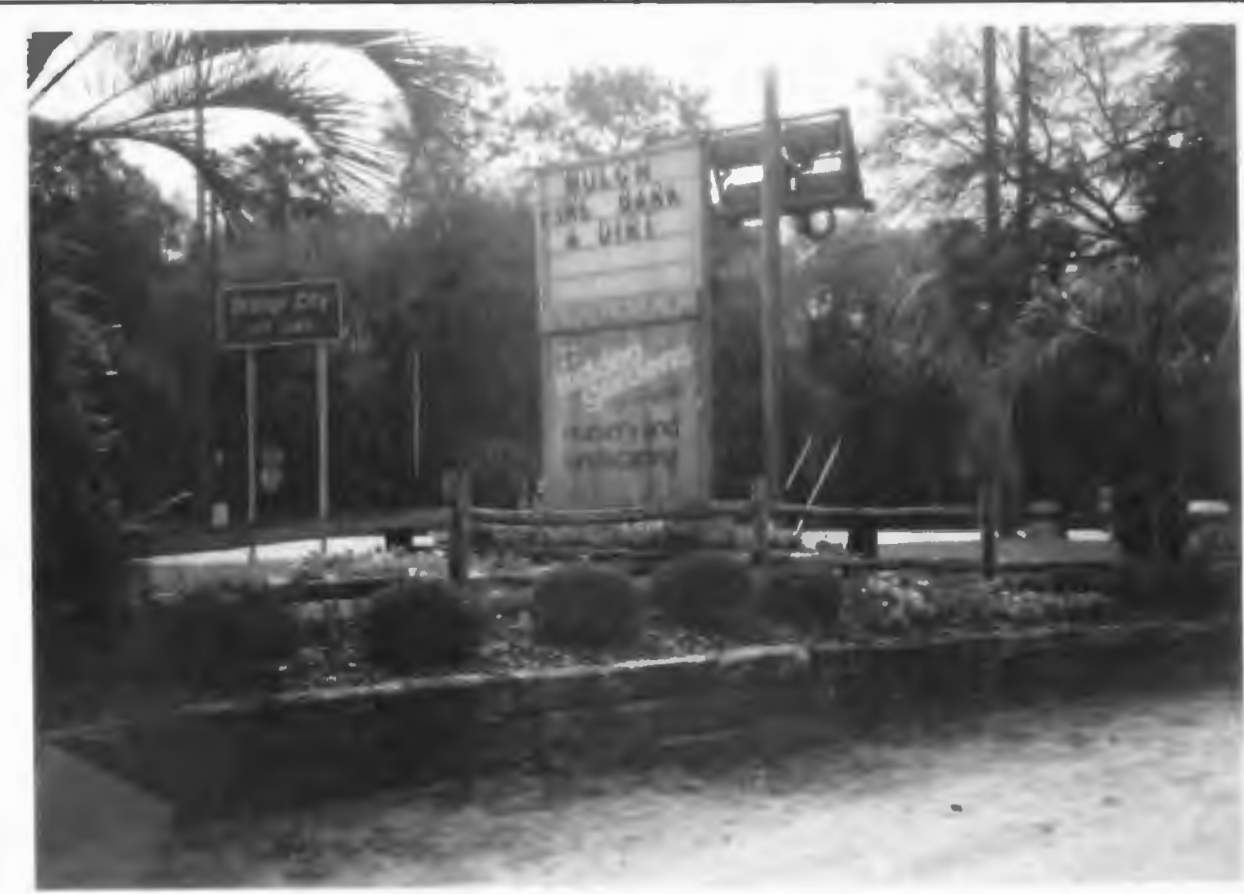

Ilustration 3.14 Example of a small, Yet Informing sign

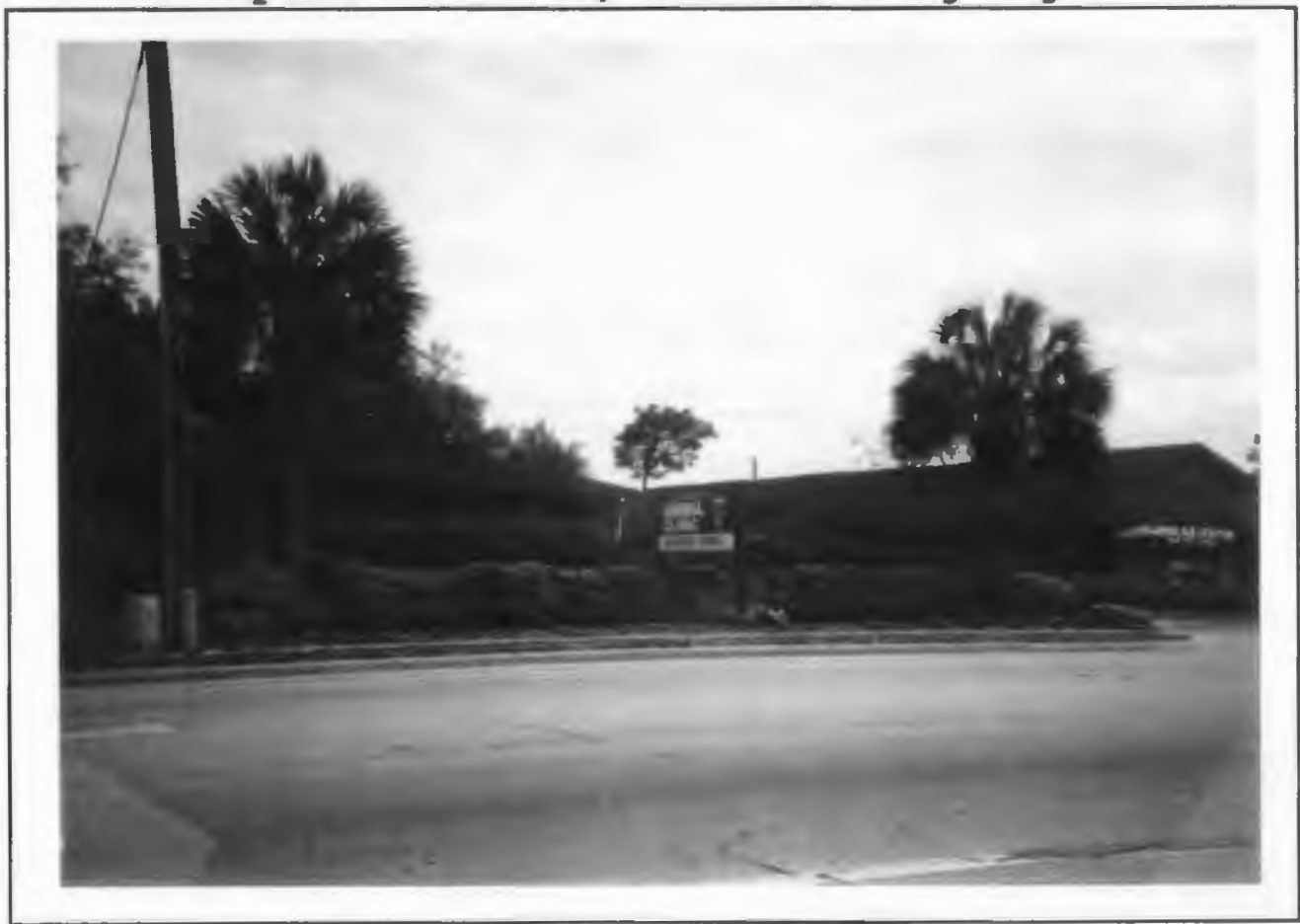

(Source: Photographs taken by the author during a site visit) 
Illustration 3.15

The Northerly Entrance sign to orange city

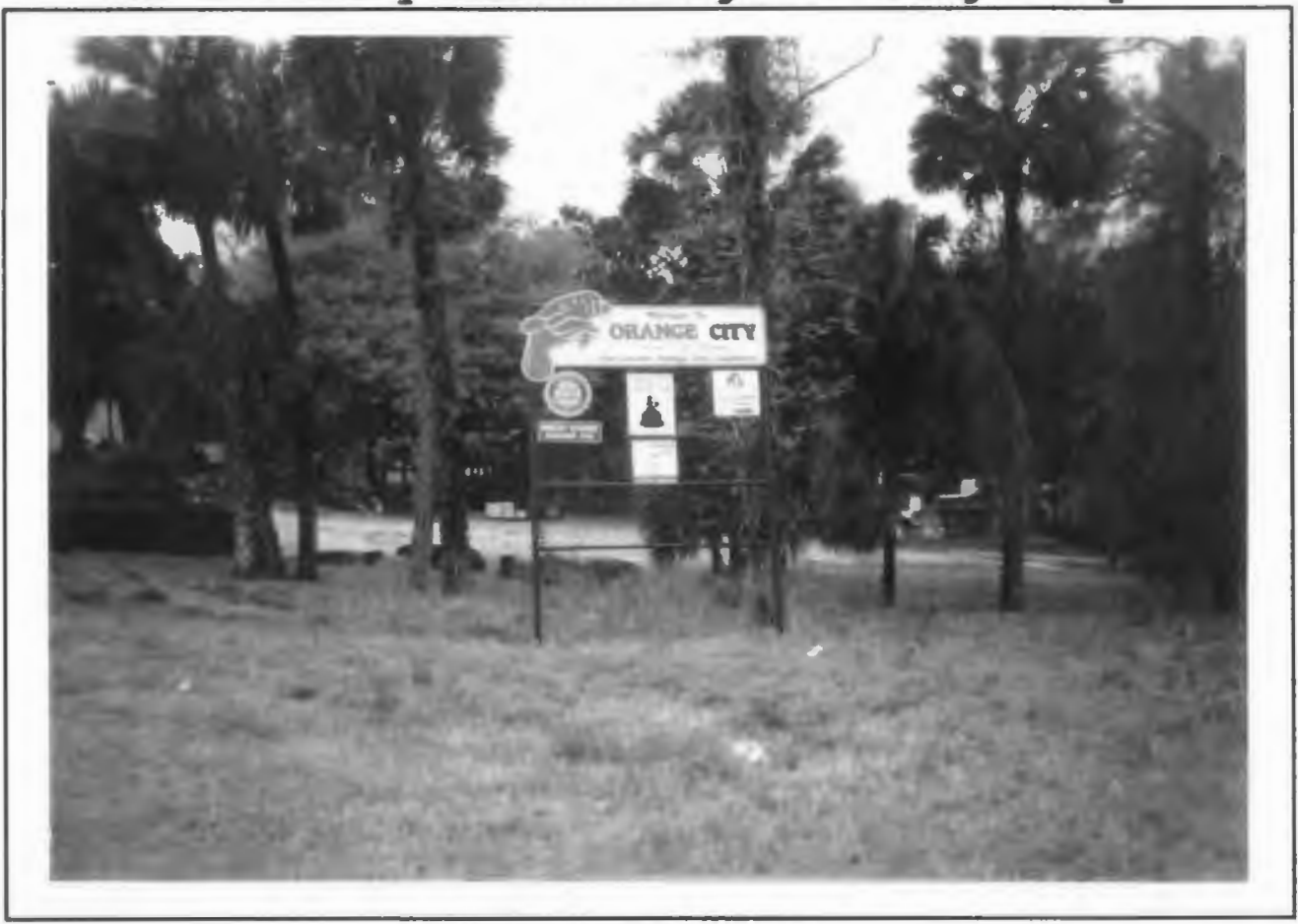

(Source: Photographs taken by the author during a site visit)

this proposal. However, during the months of February and March, 1994, a business survey and analysis was conducted, and the results of the analysis verified that all 105 (58.66\% of all existing businesses) which took part in the survey had off-street parking lots.

Table A.11 ("Business Survey Results") in the appendix, lists the location of customer parking areas in respect to the business in question. Table $A .11$ indicates that in respect to the 106 businesses which answered the survey, 51 (48\%) have their parking areas located solely in the front facing the highway. An additional 27 (25.5\%) businesses have their parking areas located in the front and sides. Therefore, 78 
(73.5\%) of the businesses surveyed have some form of parking located adjacent to US Route 17-92. This has resulted in a large number of curb-cuts along the highway. Furthermore, over $95 \%$ of the parking areas are not buffered, and thus, can be viewed from the road. Only 5 (4.7\%) of the businesses surveyed had parking areas located in the rear of their buildings.

Mr. Milton Moritz, orange City's Director of Public Works, has stated that commercial owners and the public frown upon rear parking lots because of lack of visibility. As a result of this limited visibility, business owners fear that prospective customers will conceive the idea that the business is not doing well. Therefore, business owners as well as orange city resident prefer the existing situation, large number of frontage oriented parking areas and limited buffering (landscaping). Illustration 3.16 offers an example of a large parking lot along us Route 17-92.

\section{Landscaping}

As was previously mentioned, little landscaping has occurred due to the large number of parking areas lining the highway. Regardless of whether a business has the parking area located in the front or not, little landscaping exists anywhere along US Route 17-92. There are however, a few businesses which have successfully landscaped their property, and done so in some unique ways. 
Example of a Large Parking Lot Along Us Route 17-92

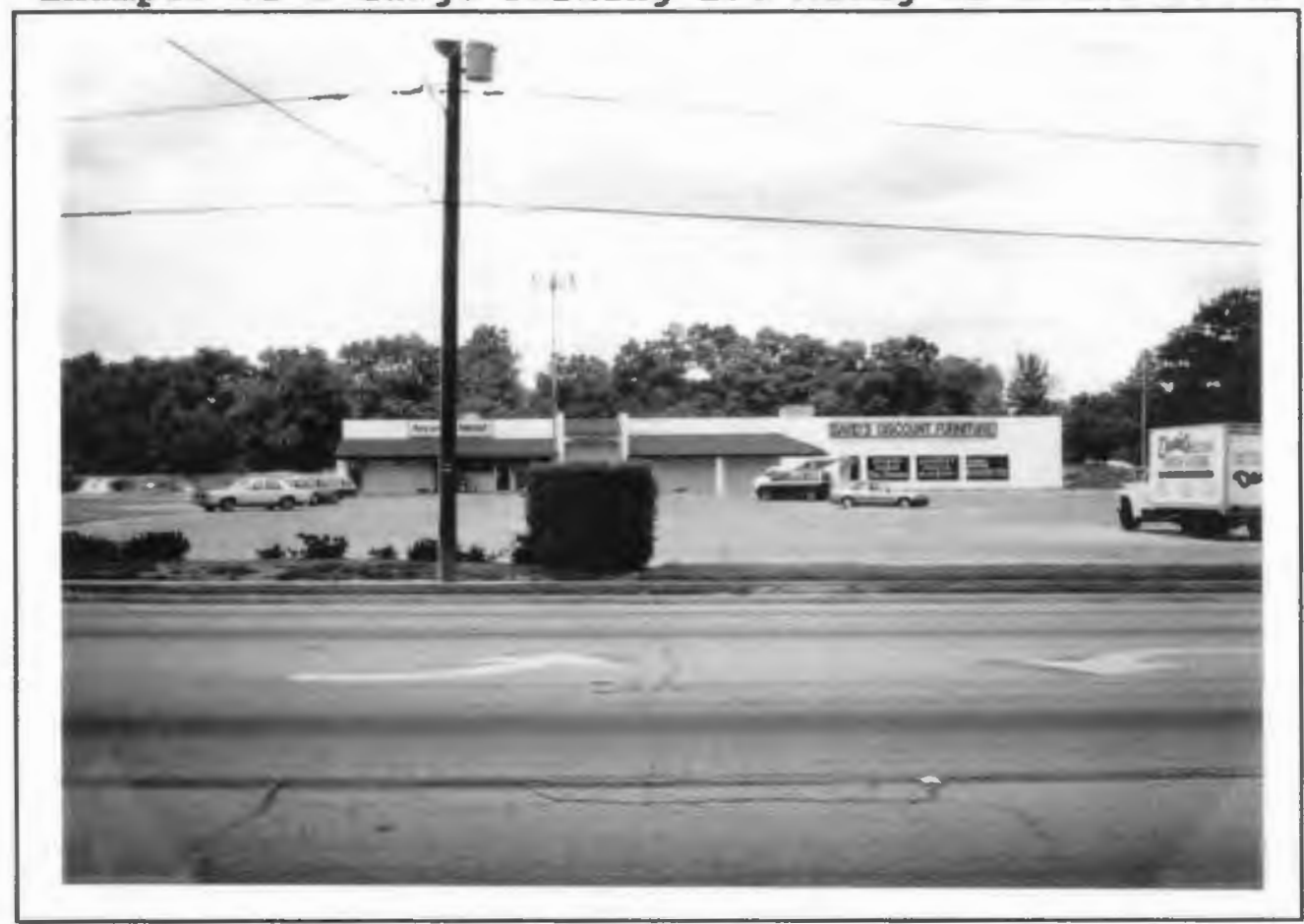

(Source: Photograph taken by the author during a site visit)

Perhaps these businesses could be utilized as an example for others to follow. In addition, orange city has requirements in their zoning ordinance which stipulate that new developments must include landscaping material. A specific example, is the new Target Department store on Enterprise Road. They had to institute landscaped islands within their parking area. Though such regulations are needed and will improve new areas under development, they may not be very effective within the project area due to the numerous preexisting establishments which do not have to conform to the new legislation. 
Pedestrian Amenities and Movement

There are for all practical purposes, absolutely no pedestrian amenities located on any portion of US Route 17-92. Due to the lack of public transportation, such features as bus shelters and benches do not exist. Trash receptacles are another feature which are not easily accessible. They can only be found in those few gas stations and convenience stores located along the highway. Public phones are another difficult amenity to find. This creates a difficult and potentially dangerous situation for any pedestrian who may be urgently in need of a phone. The only phones are once again located at gas stations, convenience stores and a commercial plaza or two.

Besides the lack of amenities which could potentially be dangerous, walking along US Route 17-92 is a hazard. Over 95\% of the project area does contain sidewalks. Those limited portions of US Route 17-92 which do not have sidewalks, do possess wide grassed areas in which pedestrians can utilize as a sidewalk. The problemed sidewalks, those few in need of repair, are primarily located on feeder roads. The real danger stems from the inability of pedestrians to safely cross the highway (see Illustration 3.17). There are five traffic lights situated along the entire length of US Route 17-92 within the project area, and they are located at the intersections of US Route 17-92 and French, Graves, Ohio, Blue Springs and Enterprise Road. These traffic lights do contain 
electronically controlled systems to allow pedestrians to safely cross the highway. However, it is the limited amount of time given to pedestrians which creates the hazardous situation. US Route 17-92 is 64 feet wide and the electronic timers offer approximately 16 - 18 seconds of crossing time. 8 The reason for offering approximately $16-18$ seconds, is due to the average four foot per second pace which a person walks and the existing width of the highway. Therefore, $16-18$ seconds would offer enough time for an average pedestrian to safely cross the highway with a few extra seconds to spare. The extra time offered, however, is limited, and thus, a person must be ever watchful that he/she commit themselves to completing the task of traversing the highway. Any delays could potentially turn into a hazardous situation. The real concern stems from those pedestrians who are elderly and/or handicapped. Whereas the average person is capable of walking at a four foot per second pace, senior citizens and the handicapped take twice as long. ${ }^{9}$ Therefore, it is extremely difficult, if not impossible, for the elderly and disadvantaged to safely cross US Route 17-92 at an electronically controlled intersection.

\section{BLUE 8PRINGB PARK}

Orange city is known as the home of the manatee, and thus, holds a yearly manatee festival, because of Blue springs Park and the manatees which migrate there during the winter 
Illustration 3.17

Example of a Pedestrian Attempting

to Cross Us Route 17-92

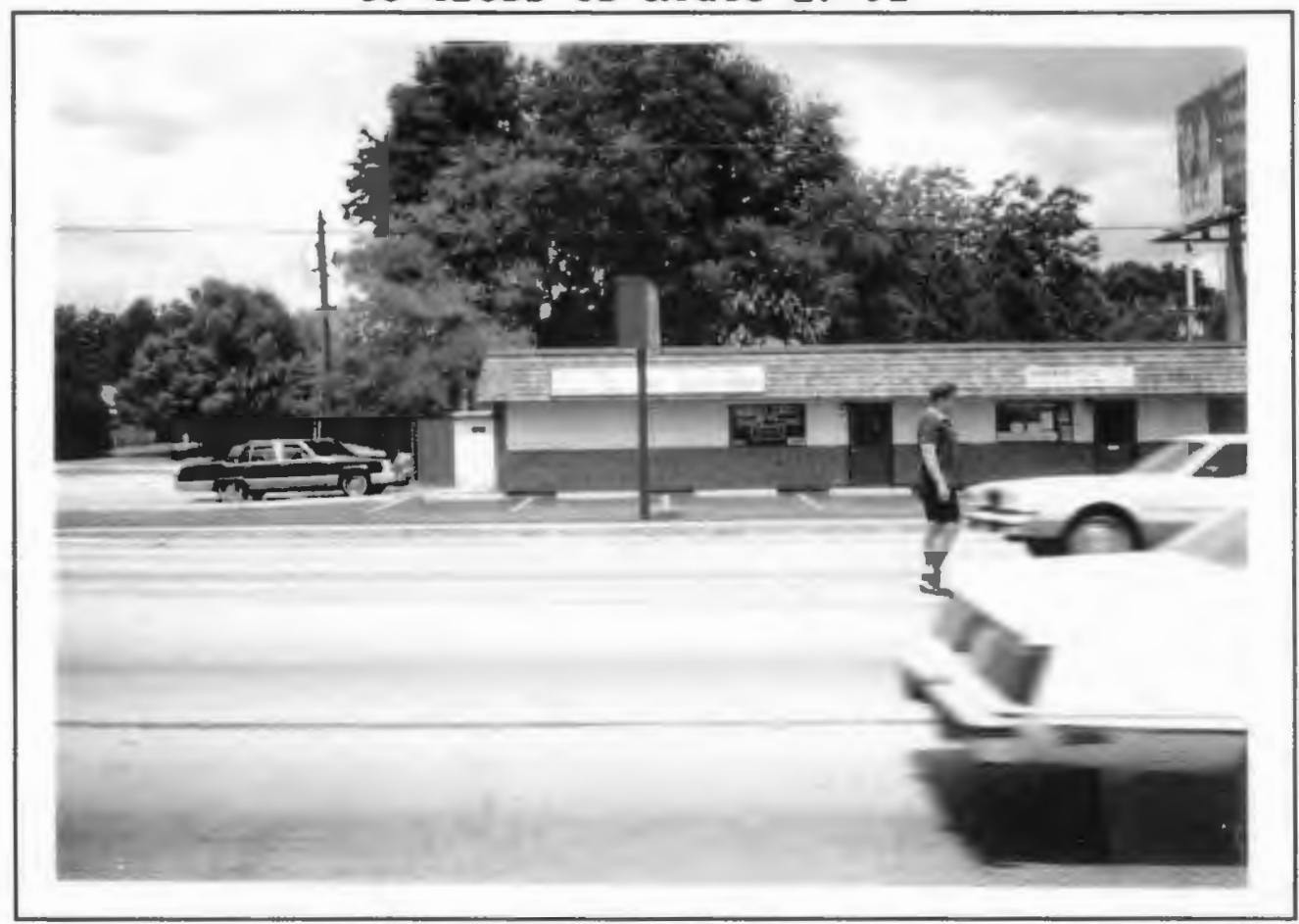

(Source: Photograph taken by the author during a site visit)

months. Blue Springs Park is truly an unique place. Not only do the manatees make regular yearly visits to the area, but other species of life migrate there. These other species include a number of reptiles, such as alligators, and a variety of fish inhabit the waters of Blue springs. Blue springs is also rich from a historical perspective. Indian mounds from the 1500 s and earlier have been found there. In addition, the first orange city settler, Louis P. Thursby, built his home along the st. Johns River in Blue Springs Park. In fact, the home still stands, with some minor alterations, thereby, attracting visitors from all over. From a 
recreational perspective, the spring remains at a constant $72^{\circ}$, and thus, locals as well as non-locals can be found swimming their on an almost year round basis. Illustration 3.18 contains three photographs of those features which can be found at Blue Springs Park; the manatee which migrates there yearly, the natural spring which is utilized year-round for swimming purposes, and Louis P. Thursby's home.

\section{GUMLARY OF FINDINGS}

The traffic analysis has shown that US Route 17-92 has been experiencing tremendous increases in both automobile usage and the occurrences of automobile accidents. Us Route 17-92 has endured a 125.7\% increase in traffic loads since 1978, and between the years of 1987 - 1992 has been the scene of over 376 reported accidents ${ }^{10}$ and 472 resulting injuries. Such figures are astounding and should be cause for concern. In addition, limited road construction and rehabilitation has led to street deterioration and required costly infrastructural improvements. Any further neglect will only allow the road conditions to become critical, thereby creating a costly situation which may be insurmountable.

In regards to the existing businesses, there seems to be a sufficient variety required to meet the needs of orange city residents as well as surrounding communities. Some vacant parcels and structures do exist, but the number is extremely small. Furthermore, due to constant inquiries made by outside 


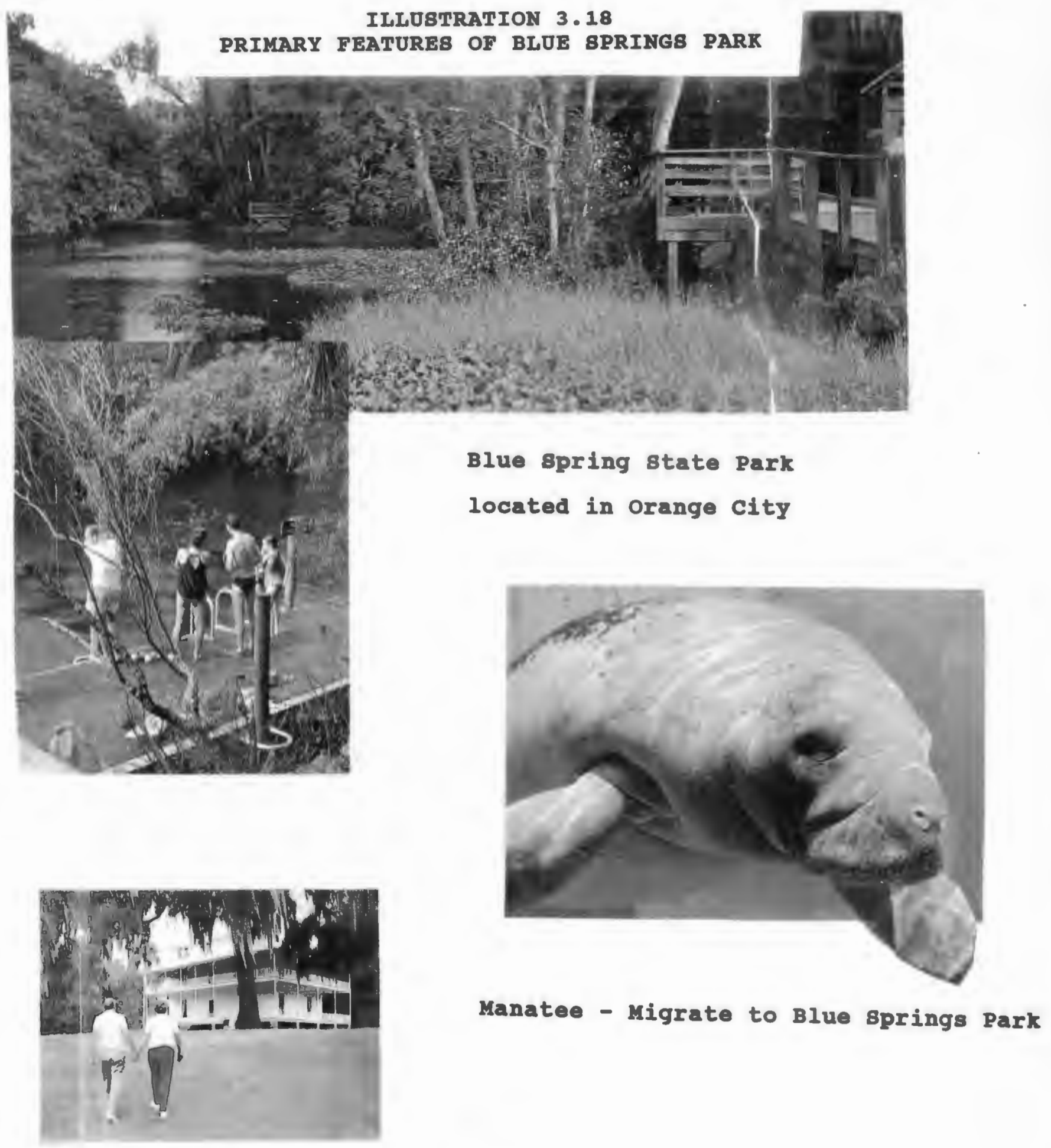

Original Home of Louis P. Thursby

Source: Greater Orange City Area Chamber of Commerce (A Guide to Orange City, Florida) 
business sources, the city has little concern from an economics perspective. The city's real concern is in regards to the lack of attention to aesthetics as well as city ordinances, (e.g. ignoring maximums imposed on sign measurements). Businesses occupy over $97 \%$ of the total land area along US Route 17-92, and thus, must do their part to correct the wrongs which have become commonplace. Such oversights as the inattention to landscaping, appropriate and attractive signage, buffering and placement of parking areas, as well as upkeep of their establishments, has not helped the situation. However, as the analysis of existing conditions has indicated, there is little desire to change the current situation. A clear example of this is in regards to the placement of parking lots. Not a single entity, including business owners, residents or the city, will attempt to alter the manner in which parking areas are placed. They prefer it as such for those reasons previously discussed, and thus, change is either unwanted or practically impossible to institute. Change will only occur to those specific areas in which mutual support can be achieved.

orange city itself can institute some enhancing changes (e.g. improve city entrances), and begin circulating information about its valuable resources. Such advertising will both improve existing perceptions as well as inform the general public about specific nodes and focal points. These focal points include the Town Hall, the rich history of the 
area, and specifically, Blue springs Park which is the home of the manatee and orange City's first permanent resident. 
'Staff, "Council Unlikely to Vote on Mass Transit," The News Journal: West Volusia Bureau, 18 December 1991, 2(B).

${ }^{2}$ Bill Linkovich, "Crash Detail Reports from 1987 1992" (Deland, Florida: Department of Transportation, 19871992), Computer Printout. 1993 statistics will not be available till July or August, 1994.

${ }^{3} \mathrm{Mr}$. Milton Moritz, orange city Director of Public Works, interview by author, 10 February 1994, orange City, Florida, oral, orange city Town Hall, orange city, Florida.

${ }^{4}$ Ibid. (Mr. Moritz supplied the necessary information by which to calculate these estimated 1993 - 1994 construction costs)

${ }^{5}$ Craig Quintana, "Spinning Wheels on Beltline," The orlando Sentinel, 19 January 1992, K-1.

${ }^{6}$ Cindy Stefanski, "New Highways Need Access Restrictions," The Volusian, 21 July 1991, section: Viewpoint.

${ }^{7}$ Ibid.

${ }^{8} \mathrm{Mr}$. Milton Moritz, orange city Director of Public works, interview by author, 20 April 1994, orange city, Florida, telephone.

9'Ibid., oral, 10 February 1994.

${ }^{10}$ Ibid. (It is purported that upwards of $50 \%$ of all accidents are not reported, due to Florida's "No-Fault Insurance" law and its immediate impact upon a person's insurance rate once the accident is reported.) 
Two surveys were conducted in order to accurately assess the wants and needs of all orange city residents and business owners located within the project area along us Route 17-92. The first survey was oriented towards orange City residents, both year-round and seasonal. The second survey was directed at those orange city and Volusia county businesses which were located along us Route 17-92 within the project area. This chapter describes the methodology, results and significance of each of these surveys.

\section{RESIDENT SURVEY}

Survey Methodology

The resident survey consisted of two informational questions, sex and age, and ten opinionated questions which were further comprised of several sub-component parts (see Table A.8 in the appendix). All the questions were fashioned so that they were answerable with a simple "yes or no" response. Due to the forth-right manner in which the respondents offered information above and beyond the preconstructed questions, an eleventh and open-ended question was added to the survey (see Table $A .8$ in the appendix). T $\mathrm{h}$ e survey was conducted between February 10, 1994, and March 2, 1994. The survey questions were administered by telephone, between the hours of $4 \mathrm{p.m}$. and $8 \mathrm{p} . \mathrm{m}$. The purpose for conducting the survey between these hours were two-fold; establish a time period when most residents would be at home, 
Chapter Four - Resident \& Commercial Business surveys Pg.83

and avoid conflicts which could arise by contacting people beyond a certain hour. A majority of the work force is employed between the hours of $8 \mathrm{a} . \mathrm{m}$. and $4 \mathrm{p} . \mathrm{m}$. , and thus, do not arrive at home until some time past 4 p.m. Therefore, even these pre-set survey hours established some inaccuracies which were unavoidable.

There are 2,440 households in orange city, and thus, the goal was to reach 244 , or $10 \%$ of all households. This would establish a fairly accurate assessment of those opinions shared by all orange city residents. An obvious concern was in regards to utilizing the telephone as the source of medium by which to contact orange city residents. In order to acquire accurate results, all orange city residents would have to have an equal opportunity of being reached. This in turn would require that all households be reachable, or in other words, have access to a telephone. The sprint United Telephone Service which furnishes telephone service to the entire project area, was contacted in order to assess the quantity of homes in orange city which have access to telephones. The telephone company stated that they did not have this information, nor were they able to acquire said information. Therefore, Mr. Alan Daniel, local sprint United Telephone Service Manager, was contacted in order to secure some answer. Mr. Alan Daniel stated that in his professional opinion, the bulk of orange city households had telephone service. 
Chapter Four - Resident \& Commercial Business surveys Pg.84

Households were chosen by utilizing the local phone book, and randomly selecting every eleventh name. There was no set reasoning behind utilizing the number "eleven", except for the fact that once the number was chosen, it was repeated throughout the process. All calls were allowed four rings. Should a person not be home, as many were often not, then a second attempt was made the following day. If there still was no response on the second attempt, then the household was not considered further. All phone calls proceeded in the same manner; the author introduced himself, the purpose of the call was clearly stated and the reasons for conducting the survey were explained. If at any time, the resident expressed noninterest, displeasure and/or resentment for being disturbed, the call was immediately terminated and counted as a "nonparticipatory household".

\section{Survey Results}

Approximately 1,000 households were called during the three and a half weeks in which the survey was conducted. of these 1,000 calls, exactly 176 households were contacted. The reasons for not reaching the goal of 244 households, was because of the frequency in which residents were not home and expiration of time allotted towards conducting the resident survey. Of the total, 120 households (68.18\%) participated in the survey while 56 (31.82\%) were "non-participatory". Table 
Chapter Four - Resident \& Commercial Business Burveys Pg.85

A.9 in the appendix illustrates the results of the resident survey.

The overall ratio of female to male respondents was almost two-to-one. There were $74(61.66 \%)$ female and 46 (38.33\%) male respondents. The reason for this was due to the overwhelming number of female respondents which answered the phone between the hours of $4 \mathrm{p} . \mathrm{m}$. and 5:30 p.m. Between the hours of 5:30 p.m. and $8 \mathrm{p} . \mathrm{m}$. the ratio was more or less even. According to the 1990 Census, females comprise 53\% and males 47\% of all orange city residents." Therefore, the survey respondents were $9 \%$ more heavily weighted in favor of the female sector of the population.

The predominant age of the respondents tended to be 61 and above. Exactly 75 (62.5\%) respondents were included in this age category, and an additional 15 (12.15\%) were between the ages of 51 - 60 . Therefore, approximately $85 \%$ of the respondents were aged 51 and above. According to the 1990 Census, seniors (those 61 and above) comprise $38.4 \%$ of the orange city population. ${ }^{2}$ Additionally, that sector of the population aged 51 and above comprise $9.5 \%$ of the Orange City population. ${ }^{3}$ Therefore, $48 \%$ of orange city residents are aged 51 and above. The survey respondents were $37 \%$ more heavily weighted in favor of those aged 51 and above.

The first two questions were constructed in order to obtain a resident's opinion of existing traffic concerns and/or problems. The first question requested that the 
respondent offer his/her perception of personal safety when driving along US Route 17-92 within the project area. 73 $(60.83 \%)$ households stated that they felt little or no concern in regards to driving safety, and 47 (39.16\%) households stated that there was a degree of hazard. The second question requested that the respondent offer his/her perception of the posted speed limit of $45 \mathrm{~m} \cdot \mathrm{p} \cdot \mathrm{h}$. and, whether or not, automobile drivers observed it. of the total, 92 (76.66\%) households stated that posted speed limits were acceptable while 28 (23.33\%) households declared that it could be lowered. The respondents overwhelming stated that the posted speed limit was being observed. They expressed concern over the degree of speeding that was occurring along US Route 1792.

The next two questions were constructed in order to assess resident's opinions in reference to pedestrian concerns and/or problems. The third question requested that the respondent offer his/her perception in regards to pedestrian safety along US Route 17-92 within the project area. Fiftyfour (45\%) households stated that US Route 17-92 was impassable, and therefore, unusable for pedestrian purposes. Fifty-five (45.83\%) respondents stated that they had no concerns in regards to pedestrian safety. However, a portion of these callers also stated that Us Route 17-92 was not a suitable pedestrian environment, and therefore, pedestrians should not be using it. In other words, a concern did not 
Chapter Four - Resident \& Commercial Business surveys Pg.87 exist, because it was foolish to consider such a usage in the first place. Eleven ( $9.16 \%$ ) households stated that they could not answer the question because they were unsure as to whether there was a lack of pedestrian safety or not. The fourth question was intended to acquire information regarding the unnecessary need for or shortage of pedestrian amenities; including but not limited to, trash receptacles, benches, public telephones, etc. Thirty-two (26.66\%) households stated that there was a most definite need for additional pedestrian amenities, while 40 (33.33\%) households saw no further need. Forty-eight ( $40 \%$ ) households declared that they were unsure of the answer. Many stated that they had not utilized the area in a pedestrian manner for quite some time, and therefore, could not offer an honest response.

The next four questions were constructed to assess the resident's perception in regards to the aesthetic appearance of US Route 17-92, and possible methods of upgrading said appearance. The fifth question simply requested that the respondent offer a "yes or no" answer in reference to whether they felt that the area was visually pleasing or not. Eightytwo (68.33\%) households acknowledged that they did perceive the area as visually pleasing. Whereas, 34 (28.33\%) of the households responded that in their opinion, the area was visually unpleasing. Four ( $3.33 \%$ ) households indicated that they could not decisively answer the question. The sixth question assessed resident's opinions in regards to their 
Chapter Four - Resident \& Commercial Business surveys Pg.8B perception of existing commercial signage, both from an aesthetic as well as safety perspective. The question further addressed specific signage complaints of those households whom had indicated that existing signage was visually unpleasing. Sixty-four (53.33\%) households stated that existing signage was not visually unpleasing. They further indicated that the signs were not distracting, and thus, not a safety hazard in their opinion. Forty-eight (40\%) households stated that the signage was visually unpleasing. The same respondents expressed the following concerns as reasons for perceiving the signs as visually unpleasing: 15 (31.25\%) stated that the signs were too high; $39(81.25 \%)$ stated that there were too many signs; $39(81.25 \%)$ stated that the signs were too cluttered; 15 (31.25\%) stated that the signs were poorly designed; 2 (4.16\%) stated that the signs were placed in an unsafe manner; and, $8(16.66 \%)$ stated that the signs were noninforming. Furthermore, 8 (6.66\%) households indicated that they were unsure, and therefore, could not offer a decisive answer either way. The seventh question requested that the respondent offer his/her opinion in reference to the condition of existing landscaping. Forty-nine (40.83\%) households responded that the existing landscape was adequate. Several also stated that due to the extreme urbanization of the area, further landscaping is probably impossible, and thus, the present situation is adequate. Sixty-five (54.16\%) households responded that the existing landscape is inadequate. The 
Chapter Four - Resident \& Commercial Business surveys Pg.89

remaining 6 (5\%) households were unsure, and thus, could not definitively express an answer. The eighth question asked the respondent to consider the long-term idea of placing all electrical wiring underground, as a means of aesthetically improving the area. This would additionally improve the area from a safety perspective. An overwhelming 101 (84.16\%) households immediately asserted that such an idea would be welcomed. Many iterated that such a proposal would be more important for safety concerns than any other reason. However, many stated that this recommendation would have to be implemented over a long-term period, due to the excessive cost that would be incurred. Nine (7.5\%) households stated that it would not be a good idea, nor feasible, due to the high cost. Ten $(8.33 \%)$ households responded that they were unsure of the idea, due to the potentially high costs.

The purpose of the ninth question was to procure the resident's opinions in regards to those areas which could be improved. Several categories were read off to the respondents, and their approval or disapproval was requested. The following is the list of items presented to the households, and the respective number of respondents who answered in the affirmative: 66 (55\%) stated that landscaping should be upgraded; $46(38.33 \%)$ stated that some measure should be taken to improve the existing commercial signage situation; 22 (18.33\%) stated that existing street lighting is inadequate; 50 (41.6\%) stated that the area should be improved 

to safely accommodate pedestrians; 35 (29.16\%) stated that the area required additional pedestrian amenities; 20 (16.66\%) stated that the parking areas were either inadequate or unsightly; and, 78 (65\%) stated that city gateways (entrances) should be improved as a means of promoting the city and its attractions. The last question required the respondent to reply in the affirmative or negative in regards to the placement of landscaped islands in the existing middle lefthand turn lane. Seventy-five (62.5\%) households responded positively while 30 (25\%) responded negatively. An additional 15 (12.5\%) households stated that were unsure of the effect that such an idea would precipitate, and thus, could not offer a decisive answer either way.

\section{Significance of the survey}

The purpose of the two informational questions was to accurately assess whether the survey was or was not reaching all sectors of the Orange city population. Sex-wise, females participated $9 \%$ more heavily, as compared to overall population ratios, than did males. Therefore, the survey can be considered slightly biased. However, the survey was targeting households, and thus, the voice of whomever was responding to the survey could be considered the general opinion of that particular household.

Age, on the other hand, tended to lean $37 \%$ more heavily in favor of those aged 51 and above. Such a wide discrepancy 
is crucial, and the biasness cannot be overlooked. Though the age of those refusing to participate could not be acquired, their voices tended to sound younger than the average participating household, and thus, it is safe to presume that this was the leading cause of the survey biasness. It is further safe to assume that a large portion of those aged between 16 and 50 (those under 16 are not considered due to their inability to legally drive, and thus, offer constructive criticism in regards to US Route 17-92), were either uninterested or discouraged with anything associated with US Route 17-92. Either way, a clear message can be inferred from this non-participatory action. If such an assumption is to be considered, than slightly less than one-third (31.82\%) of all households who answered the phone, were either uninterested and/or discouraged with anything associated with US Route 1792. It is for this very reason that those who did participate, must be considered the average orange city resident opinion.

The significance attained from question number one, "do you feel safe when driving along US Route 17-92", is questionable. Though, approximately $61 \%$ of the households responded positively, this does not extinguish the value of the approximately $39 \%$ of the households who declared that driving was hazardous. Therefore, the results of this question can only infer that the condition of driving is questionable, with the overall opinion leaning $21 \%$ more 
heavily towards the perception that the area is safe for drivers.

The significance to be attained from question number two, "are automobile speeds safe", is self-explanatory. Over twothirds of the households (76.66\%) declared that existing posted speed limits were safe. It is safe to infer from these results, that the majority of orange city's residents believes that present speeds should be left as they are. A point to reiterate due to its worthiness, was the assertion of respondents that drivers and their speeding habits are the problem, not posted speeds.

The significance of question number three, "is the area safe for pedestrians", is extremely difficult to appraise. Approximately $90 \%$ of the households were evenly divided in their response, with the remaining $10 \%$ replying with an "unsure" answer. Therefore, the only thing that can be inferred, is that there is a mixed opinion in regards to the degree of safety experienced by a pedestrian.

The significance of question number four, "are there enough pedestrian amenities", was additionally difficult to appraise. Though, the households responding both positively and negatively were more or less the same (approximately $27 \%$ and $33 \%$ respectively), exactly $40 \%$ responded with an "unsure" answer. Therefore, it is difficult to infer what the general orange City resident's opinion is in regards to pedestrian amenities. The primary reason asserted by those households 
Chapter Four - Resident \& Commercial Business surveys Pg.93

who responded with an "unsure" answer, was due to the lack of pedestrian activities they engaged in, and thus, inability to state whether or not an adequate quantity and variety of amenities existed.

The significance of question number five, "is US Route 17-92 visually pleasing", is easily understood. Approximately $68 \%$ of the households responded positively while only $28 \%$ responded otherwise. The remaining $3 \%$ responded with an "unsure" answer. It can only be inferred from such an overwhelming affirmative response that orange city residents consider the area aesthetically acceptable.

The significance of question number six, "is existing signage visually pleasing", is also hard to assess. Those responding positively, approximately 53\%, was not much higher than those who responded negatively, 40\%. The remaining approximately 7\% responded as "unsure". Therefore, the only inference which can be made once again, is that orange city residents are mixed in their perception of existing commercial signage. In regards to those who responded negatively, the primary two reasons offered for their answers were too many and too cluttered, with an $81.25 \%$ share respectively. The remaining reasons were only expressed by a third or less of these respondents, and thus, are not really representative of the general population.

The significance of question number seven, "is there enough landscaping", is additionally questionable. 
Approximately $13 \%$ more households (approximately $54 \%$ in total) responded negatively. However, this does not alter the fact that approximately $41 \%$ of the total households responded otherwise, which is still a significant percentage. Exactly 5\% of the households responded as being "unsure". Therefore, the only inference which can be made, is that the general opinion is mixed regarding the overall existing landscape. It is impossible to state with any certainty whether the existing landscape is acceptable or unacceptable.

The significance of question number eight, "should all electrical wiring be placed underground", is easily comprehended. An overwhelming $84 \%$ of the households responded positively. It is therefore safe to assume, that the general population would welcome such an idea. Though, actual costs were not discussed, the respondents were well aware that such a measure would be extremely expensive, and thus, commented that such a proposal would have to be implemented over a longterm period in order to be financially feasible.

Question number nine, "what areas should be improved", was constructed as a means of understanding from the resident's point of view, what areas should be targeted. Therefore, the significance of the information attained is self explanatory. The areas which were eagerly responded to were city's entrances (65\%) and landscaping (55\%). Improvement in pedestrian safety (approximately 42\%) and commercial signage (approximately 38\%), were the next two most 
Chapter Four - Resident \& Commercial Business Burveys Pg.95

responded items. The remaining concerns were responded to by less than $30 \%$ of all households. Thus, it is safe to assume that the general population does not consider these areas as highly problematic.

The tenth question, "should landscaped islands be instituted", was perhaps the most important because it posed to the household the primary idea to be recommended. Approximately two-thirds of the households responded positively. They further indicated that such a proposal would not only decrease hazardous conditions associated with pedestrians and automobile traffic, but also assist in upgrading the aesthetics of the area. Exactly $25 \%$ of the households responded negatively. Though, such a percentage is noteworthy, it is small in comparison to those who complimented the idea.

An eleventh open ended question was added to the survey, in order to allow the respondent to offer any additional comments, opinions and/or suggestions. Table 4.1 is an all inclusive list of those comments, and the number of households who stated them. The three most noteworthy comments made are; the inability of pedestrians to safely cross US Route 17-92, the hazardous situation which exists at the intersection of North Industrial Drive and US Route 17-92 (Post office location), and simply the danger which drivers must confront when turning onto US Route 17-92 from any side street. 
Table 4.1

Orange city Residents' Additional comments

\begin{tabular}{|c|c|}
\hline COMMENT & $\begin{array}{l}\text { NUMBER OF } \\
\text { HOUSEHOLDS }\end{array}$ \\
\hline Any idea should be cost efficient. & 1 \\
\hline Blue Springs Avenue needs traffic light. & 2 \\
\hline Bus service is required. & 6 \\
\hline City performing a decent job. & 1 \\
\hline City should be better promoted. & 3 \\
\hline Economic development. & 1 \\
\hline Establish alternate routes & 1 \\
\hline $\begin{array}{l}\text { Establish more readable address } \\
\text { numbers for businesses and residences. }\end{array}$ & 2 \\
\hline $\begin{array}{l}\text { Establish safer methods of crossing US } \\
\text { Route } 17-92 \text {. }\end{array}$ & 41 \\
\hline Improve street and sidewalk condition. & 9 \\
\hline $\begin{array}{l}\text { Intersection of US Route } 17-92 \text { and } \\
\text { Enterprise Road is dangerous. }\end{array}$ & 3 \\
\hline $\begin{array}{l}\text { Intersection of US Route } 17-92 \text { and French } \\
\text { Avenue is dangerous. }\end{array}$ & 1 \\
\hline $\begin{array}{l}\text { Intersection of US Route } 17-92 \text { and } \\
\text { Graves Avenue is dangerous. }\end{array}$ & 3 \\
\hline $\begin{array}{l}\text { Intersection of us Route } 17-92 \text { and } \\
\text { Minnesota Avenue is dangerous. }\end{array}$ & 1 \\
\hline $\begin{array}{l}\text { Intersection of US Route } 17-92 \text { and } \\
\text { North Industrial Drive (Post office) } \\
\text { is extremely hazardous. Traffic signal } \\
\text { required. }\end{array}$ & 15 \\
\hline $\begin{array}{l}\text { Intersection of US Route } 17-92 \text { and Ohio } \\
\text { Avenue is dangerous. }\end{array}$ & 1 \\
\hline Middle left-hand turn lane is a hazard. & 5 \\
\hline $\begin{array}{l}\text { Reduced driving due to reduction in } \\
\text { driving ability. }\end{array}$ & 12 \\
\hline $\begin{array}{l}\text { Traffic light desperately } \\
\text { required at intersection of Target and } \\
\text { walmart on Enterprise Road. }\end{array}$ & 2 \\
\hline
\end{tabular}




\begin{tabular}{|c|l|}
\hline \multicolumn{1}{|c|}{ COMMENT } & $\begin{array}{l}\text { NUMBER OF } \\
\text { HOUSEHOLDS }\end{array}$ \\
\hline $\begin{array}{l}\text { Turning onto US Route 17-92 from any } \\
\text { side street is extremely difficult. }\end{array}$ & 10 \\
\hline
\end{tabular}

(Source: Resident survey conducted by the author)

\section{COMMERCIAI BUSINESB BURVEY}

Survey Methodology

The commercial business survey consisted of one informational question, location of customer parking, and seven opinionated questions which were further comprised of several sub-component parts (see Table $A .10$ in the appendix). All the questions were fashioned so that they were answerable with a simple "yes or no" response. Due to the forth-right manner in which the respondents offered information above and beyond the pre-constructed questions, an eighth and open-ended question was added to the survey.

The survey was conducted between February 21, 1994, and March 2, 1994. The survey questions were personally hand delivered during business hours, $9 \mathrm{a} . \mathrm{m}$. to 4 p.m. If a business was closed due to odd operational hours (e.g. Pier Sixteen Restaurant which is only open in the evening), or during the noon lunch hour as many businesses frequently do, then a second attempt was made on a consecutive day. Those businesses which were not surveyed were overlooked for either of three reasons; inability to contact, refusal to 
participate, or lack of commitment in regards to answering the delivered survey.

There are approximately 179 businesses located on both sides of US Route 17-92 within the project area. Over $90 \%$ of the businesses are located within orange city, with the remaining businesses (all on the southerly side near the intersection of Enterprise Road), located within Volusia county. The goal was to survey all 179 businesses, and thus, an attempt was made to contact each and every business within the project area. In so doing, a fairly accurate assessment of those opinions shared by all orange city businesses would be attained.

Those businesses which agreed to participate, were given a week to answer the survey. Several attempts were then made in their collection, the last occurring on March 2, 1994. Any business(es) which were still unprepared as of this last collection date, were instructed to deliver the survey to the orange City Planning Department at the orange City Town Hall.

\section{Survey Results}

There are approximately 179 businesses located within the project area. Exactly 105 surveys (58.66\%) were collected. The remaining 74 businesses did not participate for either of the three previously stated reasons. Although, 105 businesses completed the survey, many did not answer several questions. Therefore, an "unanswered column" had to be included in order 
to have each question total 105. Table $A .11$ in the appendix illustrates the results of the business survey.

Due to the new proposal by the Department of Transportation regarding the elimination of on-street parking ${ }^{4}$, an analysis of existing customer parking was also conducted as an aspect of the survey. Customer parking was located as follows: 50 (47.62\%) parking areas were located solely in the front of the business facing outward towards Us Route 17-92; 27 (25.71\%) parking areas surrounded the business; 23 (21.90\%) parking areas were located solely on the side; and, only 5 (4.76\%) parking areas were located to the rear of the business, hidden from the highway. Therefore, the predominant location of parking was in the front with $47.62 \%$ located solely in the front, and an additionally $25.71 \%$ located on all sides including the front. The purpose of the first question, "existing personal problems", was to discover whether or not existing businesses were having difficulty from an operational perspective. In other words, were any of the following conditions causing problems in the operation of their everyday activities. The first component inquired about the traffic situation within the immediate area of their business, and whether or not it was causing them any difficulty. Sixty-nine $(65.71 \%)$ businesses declared that traffic was causing problems, while 32 (30.47\%) businesses asserted otherwise. of the remaining four businesses, 1 $(0.95 \%)$ answered as "unsure", and $3(2.86 \%)$ did not offer an 
answer. The second component inquired as to how safe (crimewise) it is to conduct business in the area. Forty-five (42.86\%) businesses declared that safety was not an issue, while an additional $49(46.66 \%)$ businesses asserted that there were safety concerns. of the remaining 11 businesses, 4 (3.81\%) answered as "unsure", and 7 (6.66\%) did not offer an answer. The third component inquired as to the visibility of the business from the highway. Twenty-seven (25.71\%) businesses declared that they were not clearly visible, and thus, a problem existed. Sixty-eight (64.76\%) businesses answered that visibility was not a problem. of the remaining 10 businesses, 1 (0.95\%) answered as "unsure", and 9 (8.57\%) did not offer an answer. The fourth and final component addressed the issue of parking, and whether or not a need existed for any additional parking. Twenty-eight (26.66\%) businesses declared that parking was limited, whereas 67 $(63.81 \%)$ businesses asserted that they had sufficient parking for customers. Of the remaining 10 businesses, 3 (2.86\%) answered as "unsure", and 7 (6.66\%) did not offer an answer.

The second question, "existing problems along US Route 17-92", was constructed in order to attain the opinions of business owners in regards to any existing problems along Us Route 17-92. Whereas question number one raised concerns in reference to problems affecting the business owner specifically, this question was included for the purpose of acquiring a general perception of the area. The first 
Chapter Four - Resident c Commercial Business Burveys Pg.101

component asked the business owner to offer his/her opinion in regards to pedestrian safety. Forty-nine (46.66\%) businesses answered that the area was more or less safe for pedestrians. Forty-four (41.90\%) businesses asserted otherwise, declaring the area was unsafe. of the remaining 12 businesses, 10 (9.52\%) answered as "unsure", and 2 (1.91\%) offered no answer. The second component inquired as to the perception of business owners in regards to the existing traffic situation. Sixtyseven (63.81\%) businesses answered that the existing traffic volumes were heavy. Thirty-one (29.52\%) businesses answered that traffic volumes were normal, and thus, no problem existed. Of the remaining 7 businesses, 6 (5.71\%) answered as "unsure", and 1 (0.95\%) offered no answer. The third component inquired as to the issue of accidents, and whether or not the area experienced an abnormal amount. Fifty-one (48.57\%) answered that there were an abnormal amount of accidents within the vicinity of their business. ${ }^{5}$ Thirtythree ( $31.43 \%)$ businesses declared that due to the nature of the highway and high traffic volume, they did not consider the situation as abnormal. Of the remaining 21 businesses, 18 (17.14\%) answered as "unsure", and $3(2.86 \%)$ offered no answer. The fourth and final component inquired as to their perception of the existing posted speed limit. Forty (38.10\%) businesses responded that the speed limit was ineffective, whereas $54(51.43 \%)$ businesses asserted that the posted speed limit was adequate. Of the remaining 11 businesses, 7 (6.66\%) 
answered as "unsure", and 4 (3.81\%) offered no answer.

The purpose of question number three, "personal considerations", was to attain the perception of business owners in regards to the aesthetics of the area. Aesthetics are comprised of several components, and therefore, the survey made several objective inquiries. Component number one inquired as to their perception of the existing quantity of commercial signage. Thirteen (12.38\%) businesses answered that there were too many signs, whereas 4 (3.81\%) declared that there were too few. Sixty-five (61.90\%) businesses stated that the existing quantity is acceptable. of the remaining 23 businesses, 12 (11.43\%) answered as "unsure", and 11 (10.47\%) offered no answer. The second component inquired as to their perception of the existing height of commercial signage. Eight (7.62\%) businesses answered that some signs were too high, whereas 77 (73.33\%) businesses declared that signs in general were acceptable. of the remaining 20 businesses, 10 (9.52\%) answered as "unsure", and 10 (9.52\%) offered no answer. The third component inquired as to their perception of the existing landscape. Twenty-five (23.81\%) businesses answered that the existing landscape was inappropriate, while 50 (47.62\%) businesses declared otherwise. of the remaining 30 businesses, 16 (15.24\%) answered as "unsure", and 14 (13.33\%) offered no answer. The fourth component inquired as to their perception of existing street lighting. Twenty-three (21.90\%) businesses asserted 
Chapter Four - Resident Commercial Business Burveys Pg.103 that the street lighting was inadequate, while 55 (52.38\%) declared that the existing street lighting was adequate. of the remaining 17 businesses, 10 (9.52\%) answered as "unsure", and 17 (16.20\%) offered no answer. The fifth component inquired as to their opinion on whether or not there was an adequate amount of pedestrian amenities. Thirty-two (30.47\%) businesses answered that there were too few amenities, whereas a single business $(0.95 \%)$ stated that were too many. Thirtyeight (36.20\%) businesses declared that the present quantity was acceptable. of the remaining 34 businesses, 18 (17.14\%) answered as "unsure", and 16 (15.24\%) offered no answer. The sixth and final component inquired as to their opinion on whether or not existing city entrances (gateways) were adequate. Forty-three (40.95\%) businesses answered that the existing entrances needed improvement, while 26 (24.76\%) declared that they were fine. Of the remaining 36 businesses, 27 (25.71\%) answered as "unsure", and 9 ( $8.57 \%$ ) offered no answer.

The fourth question, "should wiring be placed underground", was included in order to attain the business owner's opinion towards the idea of placing all overhead electrical wiring underground. Forty-nine (46.66\%) business owners stated that this proposal would be well received, while $29(27.62 \%)$ asserted that it was not required. Twenty-seven (25.71\%) businesses answered as "unsure". 
The fifth question, "is us Route 17-92 visually pleasing", was constructed in order to attain an overall perception towards the appearance of the area. Forty-four (41.90\%) businesses answered that in its present condition the area was aesthetically pleasing, whereas 47 (44.76\%) businesses answered otherwise. Fourteen (13.33\%) businesses answered as "unsure".

The sixth question, "is US Route 17-92 pedestrian friendly", was included in order to attain the overall opinion of business owners towards the area and its treatment of pedestrians. Thirty-one $(29.52 \%)$ businesses declared that the area was pedestrian friendly, while 60 (57.14\%) businesses answered that the area was anti-pedestrian. Fourteen (13.33\%) businesses answered as "unsure".

The seventh, and perhaps, most important question, "would you support a city-wide effort to upgrade US Route 17-92", was constructed in order to achieve a general sense of the business community and its willingness to remain open minded towards new ideas. The question was not necessarily established as a means of attaining financial support, though a variety of sources must be willing to offer aid if change is to occur. The primary purpose of the question was to begin the necessary dialogue required to commence necessary changes. Fifty-six (53.33\%) businesses answered that they would be prepared to support any effort to improve conditions along US Route 17-92. $18(17.14 \%)$ businesses responded that they would 
Chapter Four - Resident commercial Business surveys Pg.105

be unwilling to offer any support. And, 31 (29.52\%) businesses answered as "unsure".

Significance of the survey

Having acquired surveys from approximately 59\% of all businesses within the project area along Us Route 17-92, it is safe to state that the opinions offered are representative of the entire orange City business community. Regarding the information gathered about parking lot location, it is evident that businesses prefer placing parking where it will be easily visible from the highway. Approximately three quarters of all businesses have some form of customer parking located in the front. The most significant information obtained, however, was the fact that no businesses lacked customer parking. Therefore, the proposal by the Department of Transportation to eliminate on-street parking and widen the existing traffic lanes, will not impede the operation of any business. Another important finding, was the fact that those five businesses which had their parking areas located to the rear, were predominantly arts and crafts oriented. They tended to utilize the front of the business establishment for promotional purposes (e.g. attractive signage and display of goods).

The information obtained from question number one was rather significant. It aided in establishing a dialogue between the business owner and the city in regards to those 
issues which were affecting their operation. Approximately 66\% of the businesses surveyed, claimed that high traffic volumes were a detriment to the safe operation of their business. Businesses overwhelmingly declared that visibility (approximately 65\%) and parking (approximately 64\%) were not concerns. The remaining component, the issue of safety, was evenly divided with approximately $43 \%$ asserting that it was a problem and approximately $47 \%$ declaring that it was not.

The information obtained from question number two would be cross-referenced by the data collected in the resident survey, thereby, establishing a true consensus of those problems/concerns which exist regarding US Route 17-92. Thus, the significance of the data collected via this question is self-explanatory. High traffic volumes (congestion) was clearly identified as a problem by approximately $64 \%$ of the businesses. The remaining three components were somewhat split in their results. Therefore, it is difficult to state with any certainty from these results whether or not a problem exists in regards to pedestrian safety, travelling speeds and/or accidents.

The information obtained from question number three is highly significant, because it was obtained from those who can initiate that change which is required. Though, some of these results can be considered circumspect, due to the fact that many businesses will not respond in a manner which it perceives may increase commercial taxes (e.g. enhance the 
existing landscape), the answers are nevertheless valuable. Their value stems from the belief that businesses are both aware of the increasingly negative conditions, and the fact that long-term expenses resulting from neglect far outweigh short-term obligations. The three components which business owners overwhelmingly declared were acceptable in their present condition included; the quantity of signage (approximately 62\%), the height of signs (approximately 73.5\%), and street lighting (approximately 52.5\%). In regards to the existing landscape, the number of business owners who asserted that it was acceptable versus those who responded otherwise was more than two-to-one (47.6\% and $23.8 \%$ respectively). An inordinately high amount of business owners (approximately 41\%) responded that city entrances should be improved. However, there was also a number of those who responded that entrances were fine as they were (approximately 25\%), and oddly enough, as "unsure" (approximately 26\%). Therefore, it is not quite clear (as is the case for the other components), how city entrances are viewed by business owners. The last component, regarding pedestrian amenities, was split evenly between those who declared that there were too few $\left(30.4 \frac{8}{6}\right)$ and those who asserted that there was an adequate amount (36.2\%). Oddly enough, $32.5 \%$ of the business owners either offered no answer, or answered as unsure. Thereby, inferring that this question was either misunderstood or confusion exists. The latter is probably a more accurate 
assumption due to the unusual manner in which the answers were oddly split three ways. Therefore, no clear indication can be attained from these results.

Implementation of the recommendation (should it so be desired) quoted in question number four will directly impact business owners by aesthetically enhancing the area, therefore, the results attained are extremely significant. Approximately $47 \%$ responded in the affirmative, whereas, approximately $28 \%$ asserted that it was unnecessary. Therefore, it is safe to assume that on average, business owners would welcome such a change.

The significance of question number five, is the area visually pleasing, is questionable because the business owners were split in their views. Approximately $42 \%$ answered positively, whereas, approximately $45 \%$ asserted that the area needed improvement. Therefore, it is difficult to state with any certainty the general opinion of the business community. The question must have been a difficult one to respond to, due to the fact that $13.3 \%$ of the owners could not offer a decisive answer.

The overwhelming negative response to question number six, is the area pedestrian friendly, offered significant help. The response was almost two-to-one regarding the autooriented character of US Route 17-92. Therefore, it is safe to assume that the general business community shares the same views as those who responded negatively. 
Chapter Four - Resident \& Commercial Business surveys Pg.109

The significance of question number seven, whether support exists or not, is self-explanatory. The city must obtain support from residents and the business community if change is to actually occur. The majority of business owners responded favorably to the idea of upgrading us Route 17-92. It is worth noting the percentage of business owners who responded as "unsure", (29.5\%). Several of these respondents offered a reason for their indecisiveness. They hinted that change was needed, however, fear of financial support via higher taxes is what kept them from answering in a decisive manner. Therefore, it is safe to assume that a portion of these respondents would have offered their support if they had been better informed that the purpose of the question was to obtain general support.

An eleventh open ended question was added to the survey, in order to allow the business owners an opportunity to offer any additional comments, opinions and/or suggestions. Table 4.2 is an all inclusive list of those comments, and the number of businesses who stated them. The four most commented upon criticisms are; the hazardous situation which exists at the intersection of US Route 17-92 and North Industrial Drive (Post office location), the danger which the middle left-hand turn lane poses, the lack of traffic signals, and the difficulty which is encountered when entering onto Route 17-92 from a side street. 
Chapter Four - Resident Commercial Business surveys Pg.110

It is worth noting that several businesses commented during the collection of the surveys that the existing sign situation is becoming unbearable. Those who attempt to establish signage which is in compliance with city ordinances encounter severe bureaucratic obstacles, while others ignore existing legislation and situate whatever signage they prefer. A lack of enforcement has allowed many illegal signs to remain, thereby, establishing an inequitable situation. Several owners have stated that as a result of this inequity, they are prepared to follow the lessons of others and also disobey city ordinances.

Table 4.2

Business Owners' Additional comments

\begin{tabular}{|c|c|}
\hline COMMENTS & $\begin{array}{l}\text { NUMBER OF } \\
\text { BUSINESBES }\end{array}$ \\
\hline $\begin{array}{l}\text { Any change should be carefully coordinated } \\
\text { with local businesses. }\end{array}$ & 2 \\
\hline $\begin{array}{l}\text { Change and improvements can injure the } \\
\text { character of a city. }\end{array}$ & 1 \\
\hline city should be better promoted. & 3 \\
\hline Construct the by-pass. & 2 \\
\hline Eliminate on-street parking. & 1 \\
\hline $\begin{array}{l}\text { Establish safer methods of crossing us } \\
\text { Route } 17-92 \text {. }\end{array}$ & 4 \\
\hline $\begin{array}{l}\text { Exiting parking areas onto US Route } 17-92 \\
\text { is hazardous. }\end{array}$ & 1 \\
\hline $\begin{array}{l}\text { Extend either sparkman or Carpenter } \\
\text { Avenues further south. }\end{array}$ & 1 \\
\hline Improve street and sidewalk condition. & 2 \\
\hline $\begin{array}{l}\text { Improvement is required, but not at the } \\
\text { risk of more financial help. Taxes are } \\
\text { high already, and were paying for it. }\end{array}$ & 4 \\
\hline
\end{tabular}


Chapter Four - Resident Commercial Business surveys Pg.111

\begin{tabular}{|c|c|}
\hline COMMENTS & $\begin{array}{l}\text { NUMBER OF } \\
\text { BUSINESBES }\end{array}$ \\
\hline $\begin{array}{l}\text { Improving city entrances may be difficult } \\
\text { due to the odd configuration of orange } \\
\text { city. }\end{array}$ & 1 \\
\hline $\begin{array}{l}\text { Intersection of US Route } 17-92 \text { and Blue } \\
\text { Springs Avenue is extremely congested. }\end{array}$ & 1 \\
\hline $\begin{array}{l}\text { Intersection of US Route } 17-92 \text { and East } \\
\text { Elm Street requires a traffic signal. }\end{array}$ & 1 \\
\hline $\begin{array}{l}\text { Intersection of US Route } 17-92 \text { and } \\
\text { Enterprise Road is highly congested. }\end{array}$ & 5 \\
\hline $\begin{array}{l}\text { Intersection of US Route } 17-92 \text { and French } \\
\text { Avenue requires a left-turn signal. }\end{array}$ & 1 \\
\hline $\begin{array}{l}\text { Intersection of US Route } 17-92 \text { and French } \\
\text { Avenue is the scene of many accidents. }\end{array}$ & 2 \\
\hline $\begin{array}{l}\text { Intersection of US Route } 17-92 \text { and } \\
\text { Gardenia Drive is heavily congested. }\end{array}$ & 1 \\
\hline $\begin{array}{l}\text { Intersection of US Route } 17-92 \text { and Graves } \\
\text { Avenue is the scene of many accidents. }\end{array}$ & 3 \\
\hline $\begin{array}{l}\text { Intersection of US Route } 17-92 \text { and Mat } \\
\text { street is highly congested. }\end{array}$ & 1 \\
\hline $\begin{array}{l}\text { Intersection of US Route } 17-92 \text { and } \\
\text { North Industrial Drive (Post office) } \\
\text { is extremely hazardous. Traffic signal } \\
\text { required. }\end{array}$ & 28 \\
\hline $\begin{array}{l}\text { Intersection of US Route } 17-92 \text { and ohio } \\
\text { Avenue experiences severe congestion. }\end{array}$ & 3 \\
\hline $\begin{array}{l}\text { Intersection of US Route } 17-92 \text { and Rhode } \\
\text { Island Avenue requires a traffic signal. }\end{array}$ & 1 \\
\hline $\begin{array}{l}\text { Intersection of US Route } 17-92 \text { and South } \\
\text { Industrial Drive requires a traffic } \\
\text { signal. }\end{array}$ & 1 \\
\hline $\begin{array}{l}\text { Intersection of US Route } 17-92 \text { and } \\
\text { University Avenue is the scene of many } \\
\text { accidents. }\end{array}$ & 1 \\
\hline Leave US Route 17-92 alone. & 3 \\
\hline $\begin{array}{l}\text { Lengthen the time of crossing lights in } \\
\text { order to offer pedestrians more time. }\end{array}$ & 1 \\
\hline
\end{tabular}


Chapter Four - Resident Commercial Business Surveys Pg.112

\begin{tabular}{|c|c|}
\hline COMMENTS & $\begin{array}{l}\text { NUMBER OF } \\
\text { BUSINESSES }\end{array}$ \\
\hline $\begin{array}{l}\text { Many drivers stay well under the posted } \\
\text { speed limit, which can be extremely } \\
\text { hazardous. }\end{array}$ & 1 \\
\hline Middle left-hand turn lane is a hazard. & 9 \\
\hline $\begin{array}{l}\text { More traffic signals are required along US } \\
\text { Route } 17-92 \text {. }\end{array}$ & 8 \\
\hline On-street parking is required. & 1 \\
\hline Posted speed limit should be lowered. & 4 \\
\hline School crossings are not regarded. & \\
\hline $\begin{array}{l}\text { School crossings are the cause of traffic } \\
\text { congestion in the morning and evening } \\
\text { hours. The hours in which they are in } \\
\text { effect, should be shortened. }\end{array}$ & 1 \\
\hline $\begin{array}{l}\text { Sign ordinance either needs to be enforced } \\
\text { or eliminated because many violations are } \\
\text { occurring. }\end{array}$ & 2 \\
\hline $\begin{array}{l}\text { Traffic signal should be installed } \\
\text { somewhere between ohio Avenue and } \\
\text { Enterprise Road. }\end{array}$ & 2 \\
\hline $\begin{array}{l}\text { Turning onto US Route } 17-92 \text { from any side } \\
\text { street is extremely difficult. }\end{array}$ & 8 \\
\hline US Route 17-92 needs serious improvement. & 3 \\
\hline
\end{tabular}

(Source: Business survey conducted by the author) 
Chapter Four - Resident \& Commercial Business surveys Pg.113

${ }^{1} 1990$ Census of Population and Housing, Summary Tape File 3A, DeLand, Florida: Stetson University, 1990.

${ }^{2}$ Ibid.

${ }^{3}$ Ibid.

${ }^{4}$ Refer to page 50, Chapter 3 - Existing Conditions, for further clarification.

${ }^{5}$ Actual numbers can be attained from reviewing Tables A.2 through $A .4$ i the appendix. 
This chapter outlines the specific changes being recommended for the project area. These recommendations are developed in order to correct, or at least alleviate, existing problems, such as; traffic congestion, escalating number of accidents, condition of city streets, and the pedestrian environment. In addition, recommendations are offered regarding, amenities, signage (both private and public), landscaping as well as street lighting and overhead electrical wiring. All recommendations are constructed in order to produce the most effective outcome. Existing conditions, residents' and business owners' suggestions and perceptions, as well as the City's needs were all taken into consideration in the development of these recommendations.

The existing traffic situation, high number of accidents and road conditions were identified as the primary concerns. Therefore, the chapter begins with recommendations that address these problems. Pedestrian concerns, including their safety and the need for amenities, was of secondary importance. Therefore, these recommendations follow the traffic-oriented recommendations. The last section offers recommendations towards improving the visual appearance of the study area. 


\section{Subject: Traffic congestion}

Issues: As Chapter Three stated, certain sections of US Route 17-92 are handling traffic volumes far exceeding the allowable capacities, while other sections are handing volumes which are approaching their capacity. The existing traffic counts also illustrated that the traffic volumes on primary US Route 17-92 bisectors (French, Graves, Blue Springs, etc.), are well under their handling capacities. It was further established that a large number of vehicles travelling south-bound utilize us Route 17-92 in order to reach the commercial malls and businesses on Enterprise Road. And, the reasons for the large number of vehicles travelling north-bound is to access either I-4 by way of US Route 472 or the city of Deland.

Survey Results: The residential survey results demonstrated that $20 \%$ more respondents were not disturbed by the driving conditions along US Route 17-92. Therefore, by applying these percentages to residents City-wide, it is clear that the majority of orange city drivers are not concerned by the existing traffic situation. On the other hand, two-thirds of all businesses along US Route 17-92 asserted that the existing traffic was a concern.

Objective: Reduce congestion and improve the Level of service. 


\section{Recommendations:}

(1) The proposed West Volusia Beltline which appears will soon be a reality, will alleviate the existing traffic conditions. In conjunction with the recently completed I-4 interchange off saxon Boulevard, traffic congestion on US Route 17-92 should be reduced. As previously stated, those drivers travelling north-bound do so primarily for two reasons, to access $\mathrm{I}-4$ and to reach the city of Deland. With the new interchange, there will be no reason to proceed on US Route 17-92 (within the project area) towards I-4 by way of US Route 472 . In regards to those drivers that are heading towards the City of DeLand, it will no longer be necessary that they utilize US Route 17-92. They will be able to reach the City of Deland by way of the West Volusia Beltline and the connecting US Route 472. Likewise, those driving south-bound on US Route 17-92, do so primarily to access the commercial malls off Enterprise Road. This will no longer be required because those drivers coming from the City of Deland or East Graves Avenue will be able to access the commercial malls in a quicker manner via the Beltline express way. Those drivers coming from I-4 will be able to utilize the new interchange as well. Therefore, the only action required is to push for the construction of the desperately required West Volusia Beltine.

(2) One concern that has been raised is the limited access restrictions being imposed upon the proposed Beltline. 
Should curb-cuts and driveways be allowed to flourish as they have on US Route 17-92, the value of the Beltline will be nil. Therefore, orange city must take immediate steps to deny driveway access of any sort onto the Beltline. It is understood that the Beltline will open up enclosed parcels, thereby, establishing their value and usefulness. For economic development reasons, these parcels should be utilized to their fullest potential. However, it should be required that future developments provide access off side streets. Furthermore, new developments should be planned using the Planned Unit Development concept in order to minimize the need for ingress and egress. This will limit the need for new side streets as well as the need for any new traffic signals. The placement of new traffic signals are not recommended due to their impact on the flow of traffic.

(3) Previous attempts to establish a West Volusia Public Transportation system were unsuccessful. The resident survey indicated that the older sector of the driving population have reduced their driving habits due to a reduction in their driving ability. Furthermore, several individuals inquired about the availability of public transportation. Therefore, the city should attempt to reestablish negotiations, or at least, have a study conducted in order to query how many residents would actually use such a service. Such an analysis would offer guidance as to whether public transportation should be sought or not. 
(4) A transportation tool which has been in existence approximately twenty-five years, is the demand responsive transit service. Unlike, public transportation which operates on a fixed route, this service functions much like a taxi, (customer-activated, door-to-door transportation service). ${ }^{1}$ The differences between a taxi and this service is that several people will share a ride and usually a request is made well in advance (e.g. the evening before). Areas that have limited demand will be served by smaller vehicles, whereas, high-demand areas may be served by two or more regular-sized buses. Due to the large orange city elderly population and their reduced driving habits, it may very well be that there are enough residents who would use such a service. This would reduce the traffic on US Route 17-92, while simultaneously offering the elderly a safe mode of transportation. Because demand responsive transit service is usually operated privately, there will be no need for public funding. It is recommended that the city examine the need for such a service in the future by using a mail questionnaire.

\section{Subject: Accidents}

Issues: Chapter Three demonstrated that the project area has experienced a high number of accidents between 1987 and 1992 . Furthermore, most of these accidents have occurred at key intersections, such as Ohio, French, Graves, Blue Springs and 
Enterprise Road. The intersection of North Industrial Drive and US Route 17-92 has also been the scene of several accidents. These accidents have resulted in numerous injuries and one fatality.

Survey Results: As previously mentioned, the residential survey results demonstrated that $20 \%$ more respondents were not concerned with driving along US Route 17-92. However, several respondents also stated that they had reduced their driving habits considerably, and thus, their opinions must be taken accordingly. Several residents commented that various intersections (especially North Industrial Drive) were dangerous, and that turning onto or off US Route 17-92 was hazardous. In regards to the business survey, on average $17 \%$ more businesses responded that accidents were abnormally high, and thus, should be a concern. Businesses also commented that various intersections (especially North Industrial Drive) were dangerous and that turning onto or off US Route 17-92 was hazardous. The residents responded (62.5\%) favorably towards the idea of developing and placing islands (medians) on US Route 17-92.

objective: Reduce the number of accidents by eliminating accident prone points. 
Recommendations:

(1) Drivers must be careful of on-coming traffic when attempting to make a turn from the left-hand turn lane. Therefore, drivers must be coerced to complete their turns at a signalized intersection. This can be accomplished by placing medians (islands) in the location of the existing left-hand turn lane, and establishing openings only at specific intersections. These intersections will be augmented with traffic signals. With the proposed reconfiguration of the existing left-hand turn lane, from an existing eight-foot to a proposed twelve-foot wide, there will be ample room for an island. Islands can be erected along most of US Route 1792 within the project area. However, in those few areas (i.e. Intersection of Graves and US Route 17-92) that are not wide enough, islands cannot be placed. It is proposed that island strips (few feet in width) be placed in these areas.

Islands will include 80 foot cuts in order to allow the stacking of left-hand turning vehicles. Cuts of this size will be required because there must either be the capacity to accommodate a minimum of six to eight automobiles (ten feet in length on average and two foot spacing in-between), or two irregularly sized delivery vehicles (eighteen wheelers). It is recommended that only the following intersections be augmented with traffic signals and contain island openings (handle left-hand turns); French, Graves, Blue Springs, Ohio and Rhode Island Avenues, as well as Enterprise Road. At the 
southern end of the project area, there already exists a median strip (approximately one-tenth of a mile in length and approximately ten to twelve-foot wide). Therefore, this section only requires the placement of curbing along the outer edges in order to establish an actual island.

(2) The existing width of US Route $17-92$ is 64 feet. With the proposed reconfiguration, there will be a twelve-foot wide left-hand turn lane and two thirteen-foot wide travel lanes (or 26-feet in total) both north and south-bound. A vehicle must have a minimum of 30 feet before it can safely make a U-Turn. Therefore, it will be impossible for vehicles stacked along the islands to safely accomplish this turn. It is thus recommended that these vehicles turn onto the signalized streets, and utilize secondary roads for making the required U-Turn. This will establish a safe manner of rerouting the traffic back into the opposite direction of travel. For example, a driver travelling south-bound and desiring to visit a business located between Blue springs and Ohio Avenue would utilize the signal at Blue springs and travel east on Blue Springs, then turn right onto South Thorpe Avenue before completing the turn by making a right onto ohio Avenue. The driver would then utilize the signalized intersection at ohio and US Route 17-92 to travel north-bound on US Route 17-92, thereby, accomplishing his task without the danger of conducting a U-Turn. It is recommended that all turns be accomplished in this manner, utilizing signalized 
intersections and secondary roads for turning purposes. This will have the benefit of eliminating the existing hazard of which so many residents and business owners have commented upon at the intersection of North Industrial Drive. Anyone travelling south-bound and desiring to visit the Post office will be required to turn left onto East ohio Avenue and utilize secondary roads before turning back onto US Route 1792 north-bound. Regarding the additional traffic on the secondary roads, it has been stated that increases in volume will be minuscule. ${ }^{2}$ Figure 5.1 offers a cross-sectional view of how landscaped islands can enhance the entire project area.

(3) Due to the highly commercialized nature of the area, there is constant truck deliveries occurring throughout the day at various businesses. One business in particular, Lowe's (appliance and lumber enterprise), receives constant deliveries from a variety of sources. This type of heavy traffic can be hazardous to residential areas, both in regards to the residents who reside there and the infrastructure. Therefore, these delivery trucks must be averted from utilizing the signalized intersections and rerouting process, as is being recommended for automobiles. This can be accomplished through the placement of signage which specifies that all vehicles over a certain tonnage are prohibited. These trucks can accomplish their task by arriving in that lane of travel which will allow them to turn directly into the 
FIGURE 5.1

CROS8-8ECTIONAL VIEW OF THE PROPOSED ISLANDS

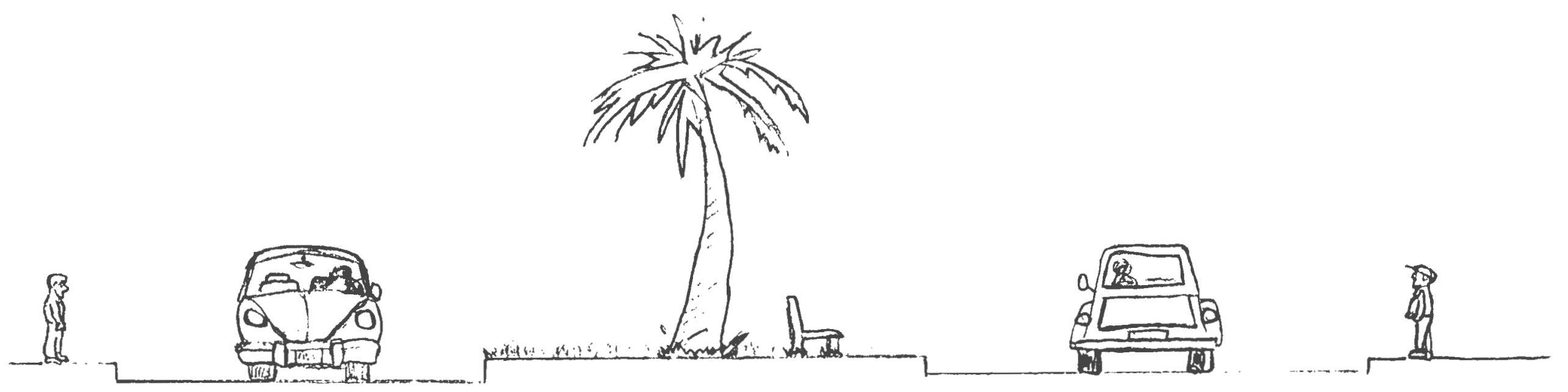


business to which they are delivering. This can be easily accomplished by utilizing the I-4 interchange off US Route 472 for those trucks delivering on the south-bound side, and the I-4 interchange off Saxon Boulevard for north-bound deliveries. Trucks which may arrive in an opposite direction, can reorient themselves by utilizing either interchange. The West Volusia Beltline, once it is constructed, will easily allow trucks to deliver their goods without having to make any turns.

(4) There will be a slight increase in the traffic volume on secondary roads should the rerouting process be instituted. Therefore, the following recommendation will ensure that only the signalized intersections (which currently are the primary US Route 17-92 feeder roads), carry the rerouting traffic. This can be accomplished through the transformation of all the remaining US Route 17-92 feeder roads into one-way streets, (except for several specific streets which are well designed feeder roads). These streets would carry traffic onto, and not away from, US Route 17-92, thereby ensuring that they are not overused. This will safeguard the condition of these roads (which were not meant to handle heavy traffic volumes), as well as the safety of all drivers by limiting the number of turning points off US Route 17-92. The following is an all inclusive list of those roads which should be transformed into one-way streets: north-bound - East Roberts, East Iris, East Gardenia, East Banana, East Rose, East Cherokee, Albertus Way, 
East Central, and Lee Avenue; south-bound - May street, West Central, West Virginia, Brooklyn, Highland, Aspen, Birch, Cedar, West Fern, and West Gardenia (see Figure 5.2). The following streets are not included, and thus, should remain as two-way streets; all signalized intersections, East Holly and West Holly, East and West Elm, Dogwood, South and North Industrial, East and West University, as well as East and West Lansdowne.

\section{Subject: Road Conditions}

Issues: Secondary roads located within the project area are in need of repairs, as verified by Mr. Milton Moritz's street analysis detailed in Chapter Three. These street sections will need to be repaired due to their expected increased usage as a result of the above recommendation. Furthermore, it is imperative that street repairs begin at once before their conditions worsen and repair costs increase.

Survey Results: Though, there was no specific question constructed which addressed the existing road conditions, several residents commented that city streets and sidewalks required repairs. The business survey, likewise, contained no specific question addressing the existing road conditions. However, two business owners commented also that streets and sidewalks needed to be repaired. 


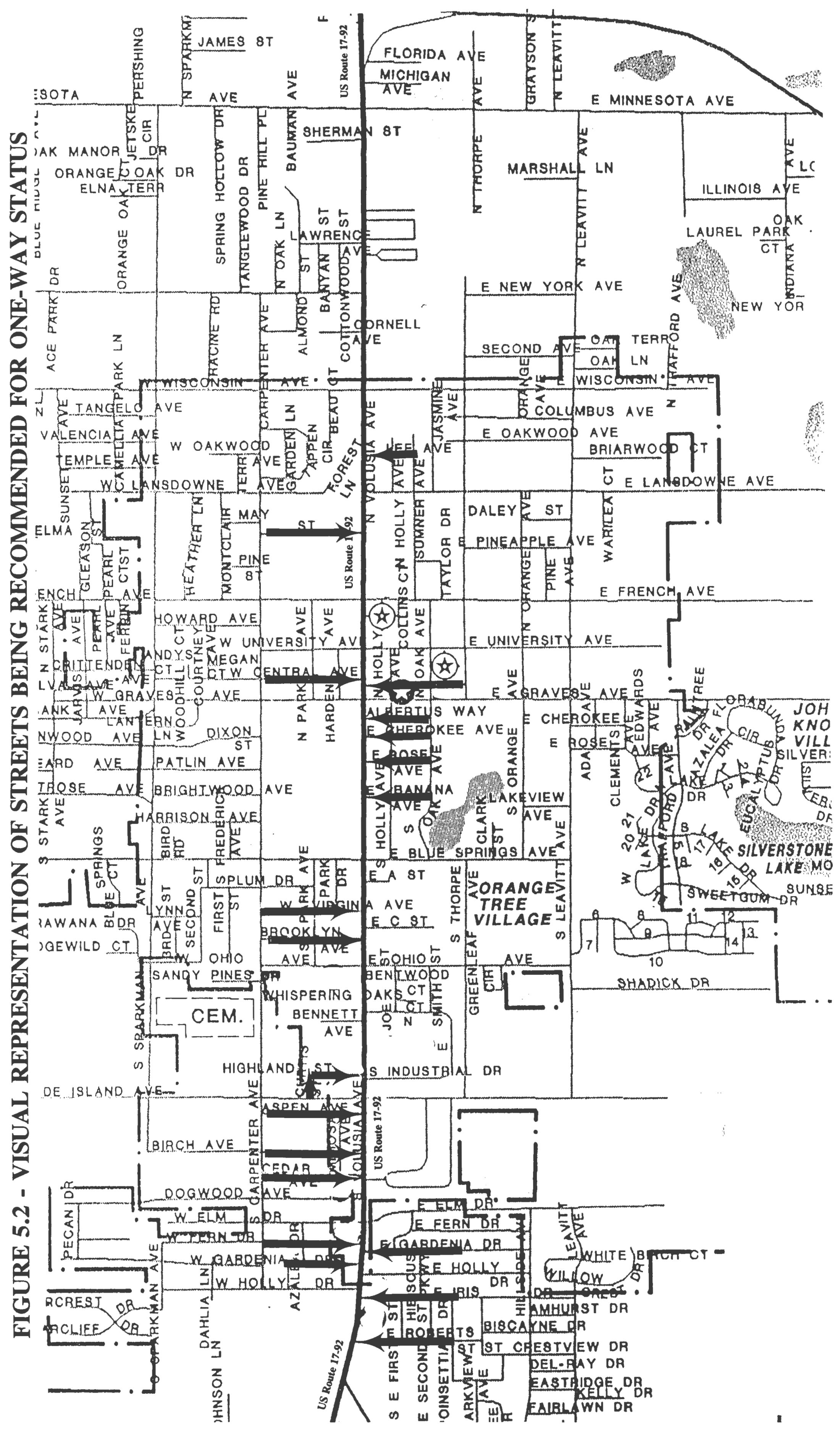


objective: Improve existing road conditions for safety as well as aesthetic reasons.

\section{Recommendations:}

(1) Road conditions need to be improved for the sake of residents as well as any driver who utilizes orange city roads. Therefore, street repairs need to be implemented immediately, and at a pace which will allow the repairs to be financially feasible. A second reason, and one which is of equal importance, is the need to improve road conditions for the purpose of handling the expected increase in usage. Once traffic is rerouted onto secondary roads for turning purposes they will be required to handle a slight increase in volume, and thus, increased wear and tear.

Given the high cost of repairing all the streets listed in the road analysis, it is recommended that repairs be conducted in four phases. The first phase should be completed in one year, and the second phase within five years. The reason for this short period of time, is due to the importance of the road sections included in the first two phases in regards to the proposed rerouting process. The first phase will cost an estimated $\$ 1,159,000$, and the second phase, $\$ 659,540$. County roads are not included in the estimated costs. It is Volusia County's responsibility to repair these designated streets, and therefore, the City must request their immediate attention. Phases three (estimated at 
$\$ 2,398,380$ ) and four (estimated at $\$ 1,239,070$ ) will be accomplished over the next ten to fifteen years. The actual costs will be somewhat higher due to inflation, however, due to the secondary importance of the streets listed in these phases their repairs can be accomplished as funding becomes available. Tables 5.1 through 5.4 list the street sections to be repaired in each phase. Figures 5.3 through 5.6 accompany Tables 5.1 through 5.4 and illustrate the roads and the repairs they require by phase.

(3) The eastern section of Rhode Island Avenue (from US Route 17-92 to South Carpenter Avenue), was not listed as requiring repairs by $\mathrm{Mr}$. Milton Moritz's analysis. However, due to the increased usage that it may encounter should the rerouting recommendation occur, it may be necessary to improve, and even perhaps, widen the street. Therefore, it is recommended that an investigation of this road on how well it will fare once the rerouting of traffic occurs be conducted.

\section{Subject: Pedestrian Environment}

Issues: Due to the severe growth of US Route 17-92 into a major highway, the increase in traffic volumes and the lack of appropriate signal devices at intersections (for crossing purposes), the project area has become unfriendly as well as unsafe for pedestrians. Sidewalks exist along both sides of US Route 17-92, and therefore, pedestrians can stroll along 
TABLE 5.1

PHABE I - ROAD REPAIR RECOMMENDATIONB

\begin{tabular}{|c|c|c|c|c|c|}
\hline STREET NAYE & $\begin{array}{l}\text { "COLLECTOR" or } \\
\text { "LOCAL Or } \\
\text { "COUNTY ROAD" }\end{array}$ & $\begin{array}{c}\text { NEW CONSTROCTION } \\
\text { OI } \\
\text { REBURPACING }\end{array}$ & FROM & TO & $\operatorname{cost}$ \\
\hline Blue Springs Avenue, E. & Collector & Resurfacing & US $17-92$ & S. Oak Avenue & 67,320 \\
\hline Blue Springs Avenue, $w$. & Collector & New Construction & S. Carpenter Avenue & US $17-92$ & 92,400 \\
\hline Carpenter Avenue, $\mathrm{N}$. & Collector & Resurfacing & W. Graves Avenue & W. Wisconsin Avenue & 201,960 \\
\hline Carpenter Avenue, $\mathrm{s}$. & Collector & Resurfacing & w. Ohio Avenue & W. Graves Avenue & 168,300 \\
\hline French Avenue, E. & Local & Resurfacing & Us $17-92$ & N. Thorpe Avenue & 64,680 \\
\hline French Avenue, $w$. & County & & N. Carpenter Avenue & US $17-92$ & $79,200 *$ \\
\hline Graves Avenue, E. & County & & US $17-92$ & N. Thorpe Avenue & $79,200 *$ \\
\hline Graves Avenue, ผ. & Collector & New Construction & N. Carpenter Avenue & US $17-92$ & 105,600 \\
\hline Lansdowne Avenue, E. & Collector & Resurfacing & US $17-92$ & N. Thorpe Avenue & 67,320 \\
\hline Oak Avenue, $\mathrm{s}$. & Local & Resurfacing & E. Rose Avenue & E. Graves Avenue & 34,300 \\
\hline Ohio Avenue, E. & Collector & New Construction & US $17-92$ & S. Thorpe Avenue & 87,120 \\
\hline Ohio Avenue, $\mathrm{w}$. & Collector & Resurfacing & s. Carpenter Avenue & US $17-92$ & 67,320 \\
\hline Rhode Island Avenue & Collector & New Construction & US $17-92$ & S. Thorpe Avenue & 79,200 \\
\hline Thorpe Avenue, $\mathrm{s}$. & Collector & New Construction & Rhode Island Avenue & E. Ohio Avenue & 118,800 \\
\hline Thorpe Avenue, S. & Loca 1 & Resurfacing & E. Ohio Avenue & E. Blue Springs Avenue & 64,680 \\
\hline Wiscons in Avenue, พ. & County & & N. Carpenter Avenue & US $17-92$ & $79,200 *$ \\
\hline & & & & TOTAL: & $\$ 1,159,000$ \\
\hline
\end{tabular}

- Repairs and upkeep of County Roods are the responsibility of Volusis County, and therefore, ane not included in the TOTAL. PHASE I strect repair costa. 
FIGURE 5.3 - PHASE I ROAD REPAIR RECOMMENDATIONS (ACCOMPANIES TABLE 5.1)

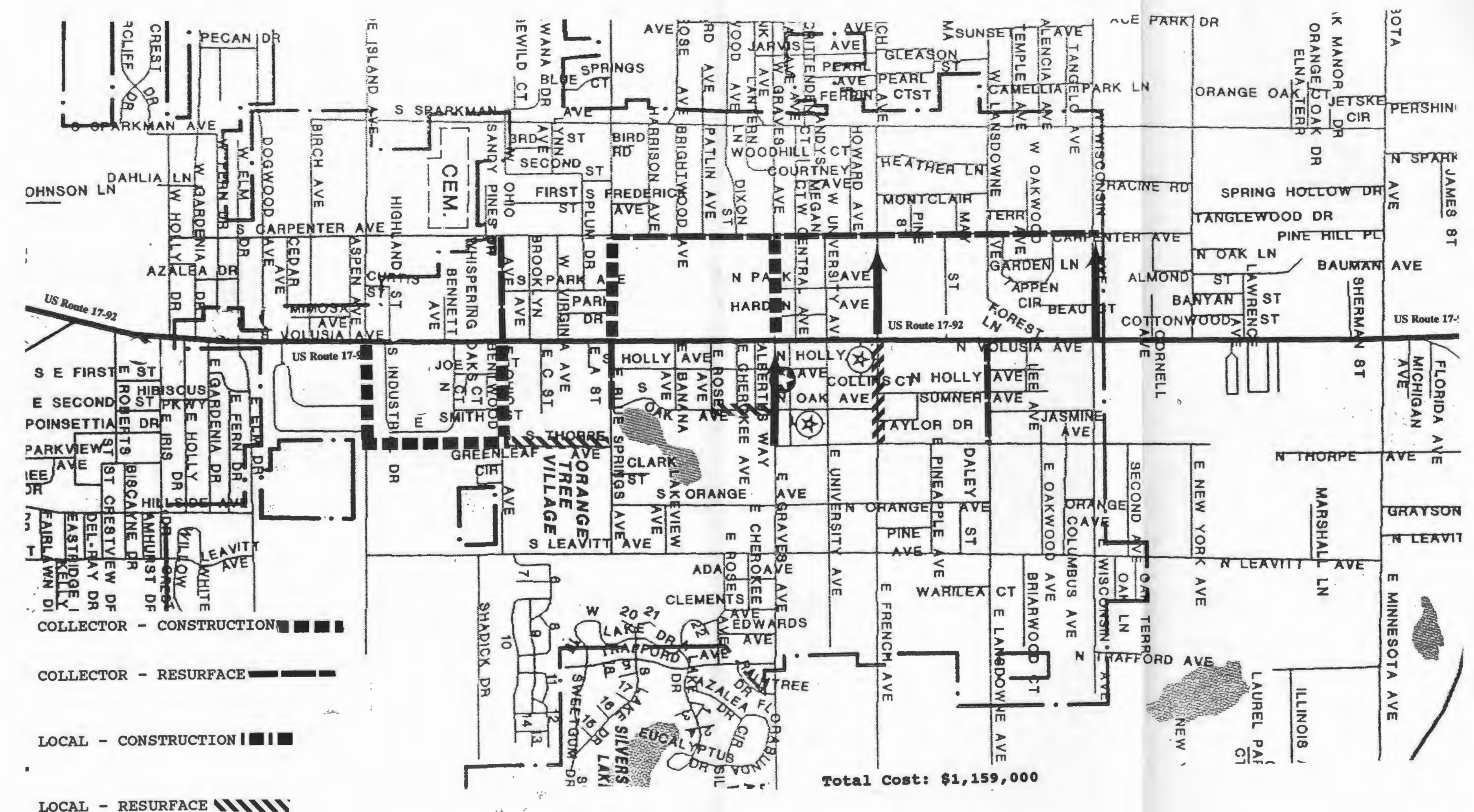


TABLE 5.2

PHABE II - ROAD REPAIR RECOMMENDATIONB

\begin{tabular}{|c|c|c|c|c|c|}
\hline STREET NAME & $\begin{array}{l}\text { "COLLECTOR" or } \\
\text { "LOCAL Or } \\
\text { "COUNTY ROAD" }\end{array}$ & $\begin{array}{l}\text { NEW CONBTRUCTION } \\
\text { Or } \\
\text { REBURFACING }\end{array}$ & FROM & TO & $\cos T$ \\
\hline Holly Avenue, s. & Local & Resurfacing & E. Blue Springs Avenue & E. Graves Avenue & $\$ 94,080$ \\
\hline Industrial Drive, E. & Collector & Resurfacing & S. Industrial Drive & N. Industrial Drive & $\$ 42,840$ \\
\hline Industrial Drive, $\mathrm{N}$. & Collector & Resurfacing & US $17-92$ & E. Industrial Drive & $\$ 57,120$ \\
\hline Industrial Drive, $\mathrm{s}$. & Collector & Resurfacing & US $17-92$ & E. Industrial Drive & $\$ 57,120$ \\
\hline Jasmine Avenue & Local & New Construction & E. Lansdowne Avenue & E. Wisconsin Avenue & $\$ 20,130$ \\
\hline May street & Local & Resurfacing & N. Carpenter Avenue & US $17-92$ & $\$ 62,720$ \\
\hline Park Avenue, N. & Local & New Construction & w. Graves Avenue & w. French Avenue & $\$ 76,860$ \\
\hline Park Avenue, s. & Local & New Construction & W. Virginia Avenue & W. Blue Springs Avenue & $\$ 40,260$ \\
\hline Sumner Avenue & Local & New Construction & E. French Avenue & E. Lansdowne Avenue & $\$ 80,520$ \\
\hline University Avenue, E. & Local & Resurfacing & US $17-92$ & N. Thorpe Avenue & $\$ 65,170$ \\
\hline University Avenue, $w$. & Local & Resurfacing & N. Carpenter Avenue & US $17-92$ & $\$ 62,720$ \\
\hline & & & & TOTAL: & $\$ 659,540$ \\
\hline
\end{tabular}

(Source: Mr. Milton Moritz, Orange City, Florida's, Director of Public Works) 


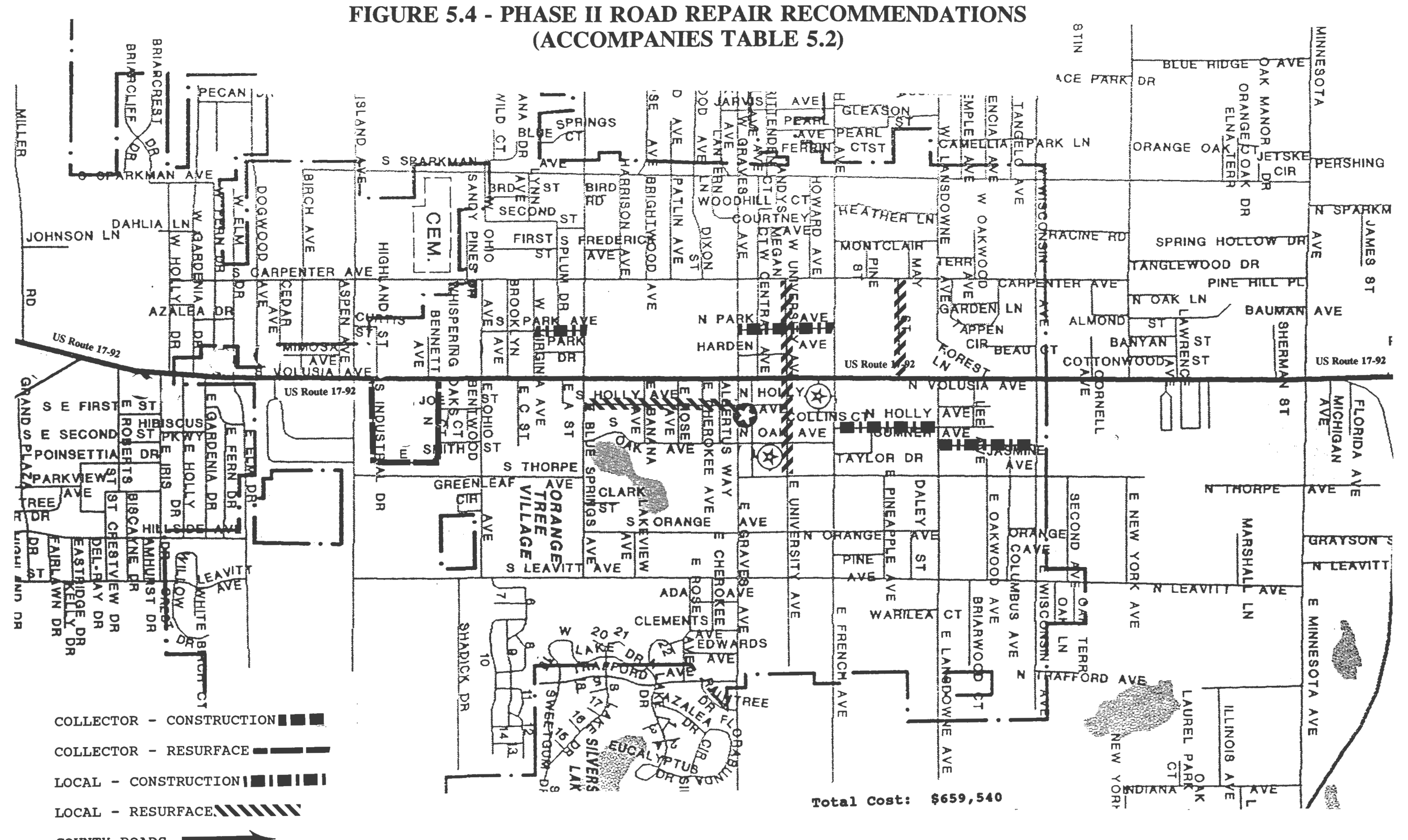


TABLE 5.3

PHASE III - ROAD REPAIR RECOMLIENDATIONB

\begin{tabular}{|c|c|c|c|c|c|c|}
\hline STREET NAKE & $\begin{array}{l}\text { "COLLECTOR" OI } \\
\text { "LOCAL Or } \\
\text { "COUNTY ROAD" }\end{array}$ & $\begin{array}{c}\text { NEW CONBTRUCTION } \\
\text { Or } \\
\text { RESURFACING }\end{array}$ & FROM & To & & $\cos T$ \\
\hline Albertus Way & Local & New Construction & s. Holly Avenue & s. Oak Avenue & $\$$ & 27,450 \\
\hline Banana Avenue, E. & Local & Resurfacing & US $17-92$ & S. Holly Avenue & $\$$ & 12,250 \\
\hline Beau court & Loca 1 & Resurfacing & W. Wisconsin Avenue & End of street & $\$$ & 39,200 \\
\hline Blue Springs Avenue, E. & collector & Resurfacing & s. Thorpe Avenue & S. Leavitt Avenue & $\$$ & 67,320 \\
\hline Blue springs Avenue, $w$. & Collector & New Construction & S. Sparkman Avenue & S. Carpenter Avenue & $\$$ & 92,400 \\
\hline Brooklyn Avenue & Local & New Construction & S. Carpenter Avenue & S. Park Avenue & $\$$ & 36,600 \\
\hline Brooklyn Avenue & Local & Resurfacing & s. Park Avenue & US $17-92$ & $\$$ & 29,400 \\
\hline C street, E. & Local & Resurfacing & US $17-92$ & End of street & $\$$ & 47,040 \\
\hline Central Avenue, $\mathbf{w}$. & Local & Resurfacing & N. Carpenter Avenue & US $17-92$ & $\$$ & 62,720 \\
\hline Cherokee Avenue, E. & Local & Resurfacing & US $17-92$ & S. Holly Avenue & $\$$ & 12,250 \\
\hline Collins court & Local & Resurfacing & French Avenue, E. & End of street & $\$$ & 12,740 \\
\hline French Avenue, E. & Local & Resurfacing & N. Thorpe Avenue & N. Leavitt Avenue & $\$$ & 64,680 \\
\hline French Avenue, $W$. & county & & s. Sparkman Avenue & N. Carpenter Avenue & $\$$ & $76,800 *$ \\
\hline Garden Lane & Local & New Construction & Tappan Circle & Tappan Circle & $\$$ & 33,550 \\
\hline Graves Avenue, E. & County & & N. Thorpe Avenue & N. Leavitt Avenue & $\$$ & $79,200 *$ \\
\hline Graves Avenue, w. & Collector & New Construction & S. Sparkman Avenue & S. Carpenter Avenue & $\$$ & 79,200 \\
\hline Holly Avenue, N. & Loca 1 & New Construction & Lee Avenue & End of street & $\$$ & 21,960 \\
\hline Holly Avenue, N. & Local & Resurfacing & E. Lansdowne Avenue & Lee Avenue & $\$$ & 16,170 \\
\hline Lansdowne Avenue, E. & Collector & Resurfacing & N. Thorpe Avenue & N. Leavitt Avenue & $\$$ & 67,320 \\
\hline
\end{tabular}




\begin{tabular}{|c|c|c|c|c|c|c|}
\hline 8TREET NAME & $\begin{array}{l}\text { "COLLECTOR" or } \\
\text { "LOCAL or } \\
\text { "COUNTY ROAD" }\end{array}$ & $\begin{array}{c}\text { NEW CONBTRUCTION } \\
\text { OI } \\
\text { REBURFACING }\end{array}$ & PROM & TO & & $\operatorname{cosT}$ \\
\hline Lansdowne Avenue, $\mathrm{W}$. & Local & Resurfacing & S. Sparkman Avenue & N. Carpenter Avenue & $\$$ & 62,720 \\
\hline Lansdowne Avenue, $\mathrm{W}$. & Local & New Construction & N. Carpenter Avenue & End of street & $\$$ & 61,000 \\
\hline Leavitt Avenue, N. & Collector & New Construction & E. Graves Avenue & E. Lansdowne Avenue & $\$$ & 184,800 \\
\hline Leavitt Avenue, $\mathrm{s}$. & Collector & New Construction & Rhode Island Avenue & E. Graves Avenue & $\$$ & 356,400 \\
\hline Lee Avenue & Local & Resurfacing & US $17-92$ & N. Holly Avenue & $\$$ & 12,250 \\
\hline Lee Avenue & Loca 1 & New Construction & N. Holly Avenue & Sumner Avenue & $\$$ & 15,250 \\
\hline Ohio Avenue, E. & Collector & New Construction & S. Thorpe Avenue & s. Leavitt Avenue & $\$$ & 87,120 \\
\hline Orange Avenue, N. & Local & Resurfacing & E. University Avenue & E. Lansdowne Avenue & $\$$ & 88,200 \\
\hline orange Avenue, $N$. & Local & New Construction & Columbus Avenue & E. Wisconsin Avenue & $\$$ & 40,260 \\
\hline Orange Avenue, S. & Loca 1 & Resurfacing & E. Blue Springs Avenue & E. Graves Avenue & $\$$ & 98,000 \\
\hline Park Avenue, N. & Loca 1 & New Construction & w. Graves Avenue & W. French Avenue & $\$$ & 76,860 \\
\hline Park Avenue, S. & Local & New Construction & พ. Virginia Avenue & พ. Blue Springs Avenue & $\$$ & 40,260 \\
\hline Park Drive & Local & Resurfacing & W. Virginia Avenue & W. Blue Springs Avenue & $\$$ & 32,340 \\
\hline Plum Drive & Local & Resurfacing & s. Carpenter Avenue & S Park Avenue & $\$$ & 32,340 \\
\hline Rhode Is land Avenue & Collector & New Construction & S. Thorpe Avenue & s. Leavitt Avenue & $\$$ & 79,200 \\
\hline Rose Avenue, E. & Local & Resurfacing & US $17-92$ & S. Holly Avenue & $\$$ & 12,250 \\
\hline Sparkman Avenue, s. & County & & พ. Ohio Avenue & W. Wisconsin Avenue & $\$$ & $435,600 *$ \\
\hline Tappan Circle & Loca 1 & New Construction & N. Carpenter Avenue & N. Carpenter Avenue & $\$$ & 100,650 \\
\hline Taylor Drive & Local & Resurfacing & E. French Avenue & Sumner Avenue & $\$$ & 34,300 \\
\hline University Avenue, E. & Local & Resurfacing & US $17-92$ & N. Leavitt Avenue & $\$$ & 130,340 \\
\hline
\end{tabular}




\begin{tabular}{|c|c|c|c|c|c|c|}
\hline BTREET NAME & $\begin{array}{l}\text { "COLLECTOR" or } \\
\text { "LOCAL Or } \\
\text { "COUNTY ROAD" }\end{array}$ & $\begin{array}{c}\text { NEW CONBTRUCTION } \\
\text { OY } \\
\text { REBURFACING }\end{array}$ & FROM & To & & $\cos T$ \\
\hline University Avenue, W. & Local & Resurfacing & US $17-92$ & N. Carpenter Avenue & $\$$ & 62,720 \\
\hline Virginia Avenue, $\boldsymbol{W}$. & Local & Resurfacing & s. Carpenter Avenue & S. Park Avenue & $\$$ & 38,430 \\
\hline Virginia Avenue, พ. & Local & New Construction & s. Park Avenue & US $17-92$ & $\$$ & 32,340 \\
\hline Wisconsin Avenue, $\mathrm{w}$. & County & & s. Sparkman Avenue & N. Carpenter Avenue & $\$$ & $76,800 \star$ \\
\hline & & & & TOTAL: & & 398,380 \\
\hline
\end{tabular}

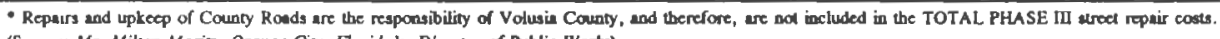

(Source: Mr. Millon Moriz. Orange Ciny. Florida's, Ditrecter of Public Wonts) 


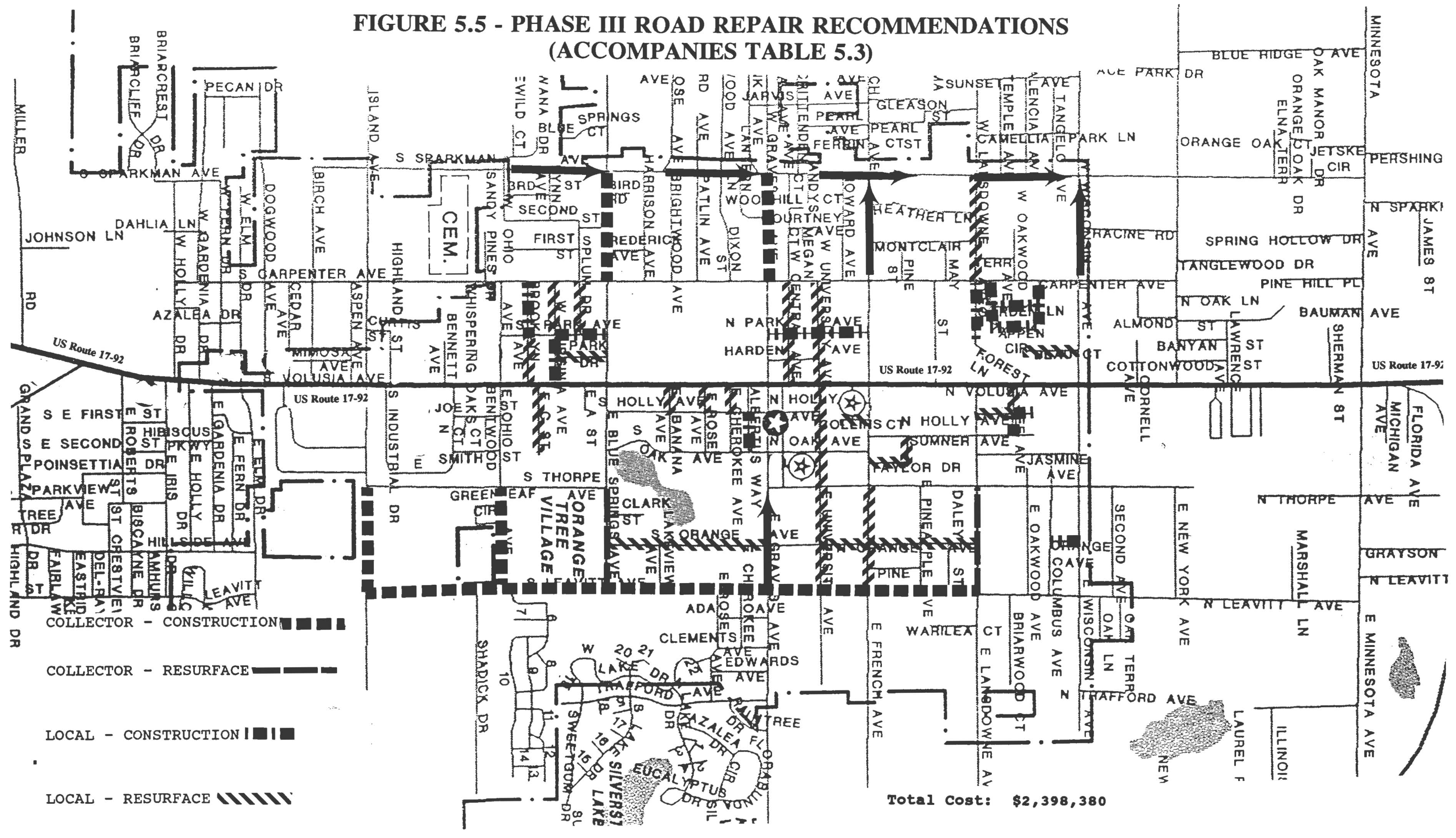


TABLE 5.4

PHABE IV - ROAD REPAIR RECOMMENDATIONB

\begin{tabular}{|c|c|c|c|c|c|c|}
\hline STREET NAME & $\begin{array}{l}\text { "COLLECTOR" OI } \\
\text { "LOCAL Or } \\
\text { "COUNTY ROAD" }\end{array}$ & $\begin{array}{c}\text { NEW CONBTRUCTION } \\
\text { OI } \\
\text { REBURFACING }\end{array}$ & FROX & TO & & cost \\
\hline Brightwood Avenue & Local & Resurfacing & S. Sparkman Avenue & N. Carpenter Avenue & $\$$ & 64,680 \\
\hline Central Avenue, $\boldsymbol{~}$. & Loca I & Resurfacing & S. Sparkman Avenue & N. Carpenter Avenue & $\$$ & 62,720 \\
\hline Columbus Avenue & Local & New Construction & End of street & N. Thorpe Avenue & $\$$ & 18,300 \\
\hline Columbus Avenue & Local & Resurfacing & N. Thorpe Avenue & N. Orange Avenue & $\$$ & 32,340 \\
\hline Columbus Avenue & Local & New Construction & N. Orange Avenue & N. Leavitt Avenue & $\$$ & 40,260 \\
\hline Daley street & Local & Resurfacing & N. Orange Avenue & N. Leavitt Avenue & $\$$ & 29,400 \\
\hline Dixson street & Local & Resurfacing & S. Sparkman Avenue & S. Carpenter Avenue & $\$$ & 63,700 \\
\hline First street & Local & Resurfacing & Plum Drive & End of street & $\$$ & 44,100 \\
\hline Frederick Avenue & Loca 1 & New Construction & w. Blue Springs Avenue & Harrison Avenue & $\$$ & 30,500 \\
\hline Harrison Avenue & Local & Resurfacing & S. Sparkman Avenue & S. Carpenter Avenue & $\$$ & 62,720 \\
\hline Howard Avenue & Local & Resurfacing & S. Sparkman Avenue & N. Carpenter Avenue & $\$$ & 62,720 \\
\hline Lakeview Avenue & Local & Resurfacing & S. Orange Avenue & s. Leavitt Avenue & $\$$ & 29,400 \\
\hline Lantern Lane & Local & Resurfacing & S. Sparkman Avenue & W. Graves Avenue & $\$$ & 39,200 \\
\hline Lynn Avenue & Loca I & Resurfacing & S. Sparkman Avenue & Second street & $\$$ & 26,460 \\
\hline May street & Loca 1 & Resurfacing & Montclair Terrace & N. Carpenter Avenue & $\$$ & 22,050 \\
\hline Montclair Terrace & Local & Resurfacing & พ. French Avenue & w. Oakwood Avenue & $\$$ & 84,280 \\
\hline Oakwood Avenue, E. & Loca 1 & New Construction & N. Leavitt Avenue & End of street & $\$$ & 76,520 \\
\hline Oakwood Avenue, w. & Loca I & Resurfacing & N. Carpenter Avenue & End of street & $\$$ & 32,340 \\
\hline Ohio Avenue, $w$. & Local & Resurfacing & S. Sparkman Avenue & Third street & $\$$ & 14,700 \\
\hline
\end{tabular}




\begin{tabular}{|c|c|c|c|c|c|}
\hline BTREET KAME & $\begin{array}{l}\text { "COLLECTOR" or } \\
\text { "LOCAL or } \\
\text { "COONTY ROAD" }\end{array}$ & $\begin{array}{c}\text { NEW CONBTRUCTION } \\
\text { Or } \\
\text { REBURFACING } \\
\end{array}$ & FROM & TO & COBT \\
\hline Orange Avenue, $\mathrm{N}$. & Local & New Construction & Columbus Avenue & E. Wisconsin Avenue & 40,260 \\
\hline Patlin Avenue & Local & Resurfacing & S. Sparkman Avenue & s. Carpenter Avenue & 64,680 \\
\hline Pine Avenue, N. & Local & Resurfacing & E. French Avenue & E. Pineapple Avenue & 29,400 \\
\hline Pine street & Local & New Construction & Montclair Terrace & N. Carpenter Avenue & 25,620 \\
\hline Pineapple Avenue, E. & Local & Resurfacing & N. Thorpe Avenue & N. Leavitt Avenue & 60,270 \\
\hline Plum Drive & Local & Resurfacing & Second street & S. Carpenter Avenue & 35,280 \\
\hline Racine Road & Local & New Construction & w. Wisconsin Avenue & W. New York Avenue & 30,500 \\
\hline Sandy Pines Drive & Local & Resurfacing & S. Carpenter Avenue & End of street & 31,850 \\
\hline second street & Local & Resurfacing & w. Ohio Avenue & W. Blue Springs Avenue & 58,800 \\
\hline Third street & Local & Resurfacing & W. Ohio Avenue & Lynn Avenue & 25,970 \\
\hline & & & & TOTAL: & $\$ 1,239,070$ \\
\hline
\end{tabular}

(Source: Mr. Milton Moritz, Orange City, Florida's, Director of Public Works) 


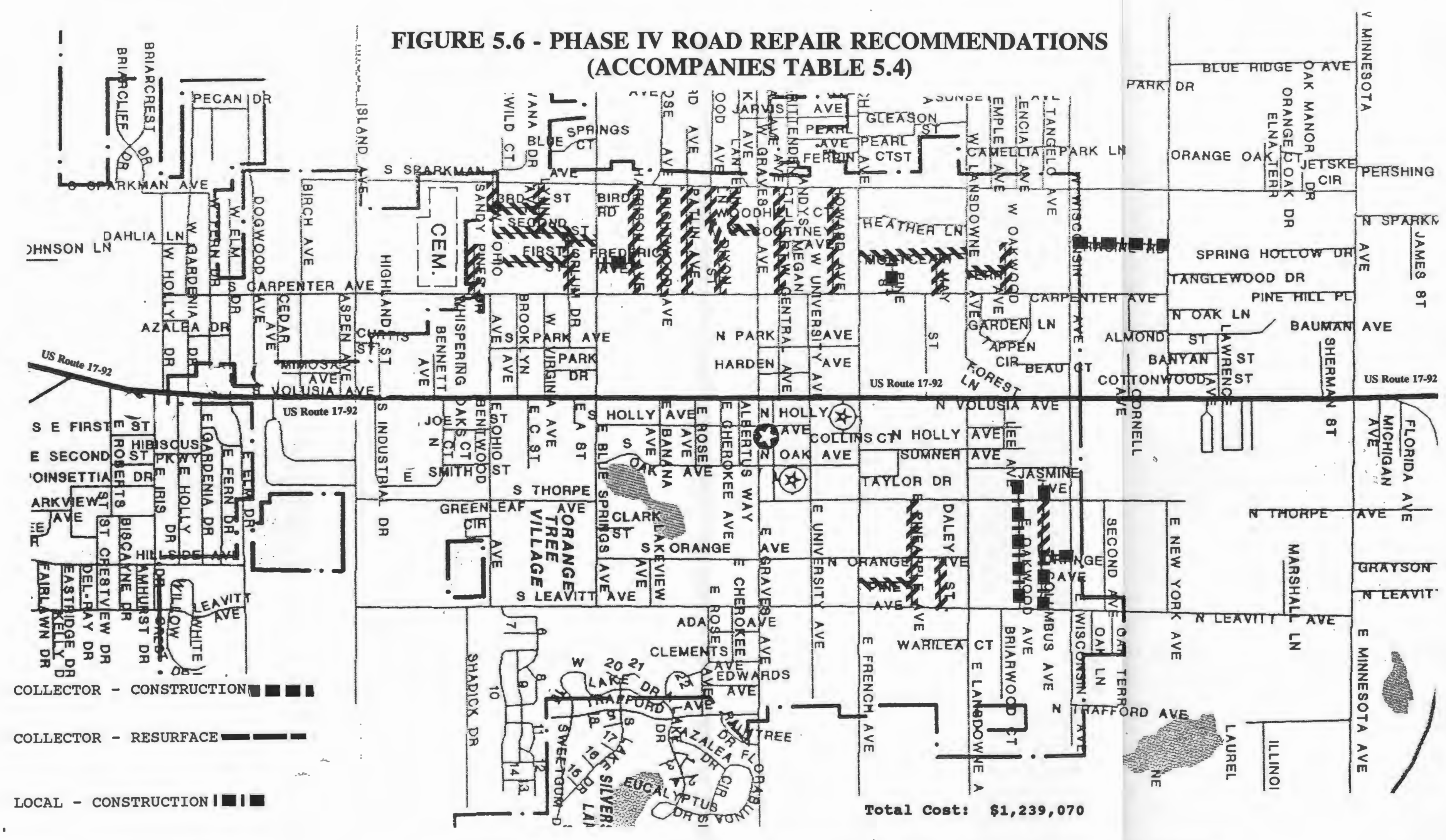

LOCAL - RESURFACE MNMY

Source: Milton Moritz, orange City Director of Public Works, Orange City Florida.

COUNTY ROADS 
the road in a straight path. However, crossing US Route 17-92 is practically impossible, especially for the elderly and the handicapped.

Survey Results: orange city residents were evenly split in their perception of the pedestrian-like atmosphere of US Route 17-92. However, $41 \%$ of the respondents stated that due to existing dangers, pedestrian movement should be improved. Furthermore, 41 respondents commented that there is a need for a safer method to cross US Route 17-92. Also, the majority of business owners responded that the project area was not pedestrian friendly. Several business owners commented that safer methods of crossing the highway need to be developed.

objective: Establish a more pedestrian-friendly environment by reducing existing traffic hazards.

\section{Recommendations:}

(1) The fundamental pedestrian hazard is crossing US Route 17-92. Therefore, any action taken will have to resolve this obstacle before the area can once again be considered pedestrian friendly. The primary reason for the danger is due to the limited amount of crossing time the signalized intersections offer a pedestrian. on the other hand, extending the crossing time will only result in increased congestion, thereby, creating a greater hazard. Therefore, it 
is recommended that once the medians have been established, a crossing period of 15 to 18 seconds be offered. This amount of time will allow an average pedestrian (four foot per second pace), to safely cross the entire expanse of US Route 17-92. Likewise, for those individuals who walk at a much slower pace (e.g. the elderly and the handicapped), this period of time will at least allow them the opportunity to reach the median (island). These individuals will then have a safety zone from which to wait for the next crossing signal. This process will allow individuals of all walking abilities to safely cross US Route 17-92 without the fear of being injured. Furthermore, the amount of crossing time being prescribed will not impede traffic, because it approximates existing crossing times.

\section{Subject: Pedestrian Amenities}

Issues: Existing pedestrian amenities are in short supply, and therefore, the area offers little in the way of attracting pedestrians. The only existing amenities are the few public telephones and trash receptacles located at gas stations and convenience stores. A greater variety and number of amenities located in appropriate places is needed.

Survey Results: Slightly more residents responded that there were limited pedestrian amenities in comparison to those who responded otherwise. Furthermore, 29\% of the respondents 
stated that the city should expand the existing variety and number of amenities. Six percent more business owners responded that there was an adequate amount of existing amenities. However, the same group responded almost two-toone that the area was not pedestrian friendly.

objective: Provide a greater variety and number of pedestrian amenities.

Recommendations:

(1) It is recommended that the medians which will be established be supplied with a quantity of park-like benches. The purpose of these benches is twofold, they will enhance the appearance of the islands and area in general, as well as offer those persons waiting for the next signalized crossing an opportunity to sit and rest. Benches should additionally be located at various locations throughout US Route 17-92. Specifically, benches should be located at the small park adjacent to the Emily Dickerson Library.

(2) More trash receptacles are required at intermittent locations along US Route 17-92, both north and south-bound. No trash receptacles should be placed upon the islands, as this will attract rubbish and clutter an area limited in space. Furthermore, it would be difficult for refuse collectors to maintain the area due to the danger of pausing their vehicles on US Route 17-92 during collection periods. 
Trash receptacles should be placed in either wooden or aesthetically pleasing metal holders, for the purpose of vandalism and/or theft. It is highly recommended that receptacles be placed at the previously stated signalized intersections. This will reduce the amount of refuse which may be collected on the islands by offering individuals an opportunity to dispose of their litter.

(3) More public telephones are needed at places which will ensure the safety of the callers. Such safe locations could be areas similar in nature to those who already have them such as, gas stations and convenience stores. These businesses usually operate on a 24 hour basis, and therefore, are well lighted and occupied by one or more individuals. other locations could include commercial business parks due to the numerous businesses located their and the number of individuals who congregate.

(4) Bus shelters and benches will be required in the future should a public transit service be instituted. Therefore, if and when the city begins to implement the above recommendations, they should additionally plot prospective locations for this specific amenity. It is highly recommended that public transportation be supported as well as the placement of these necessary amenities. 


\section{Subject: Commercial signage}

Issues: Commercial signage has been allowed to flourish in a haphazard manner, and thus, has affected the overall aesthetic appearance of the area. Furthermore, approximately one-third of the existing signs are taller than 16 feet, and thus, are non-conforming by zoning standards. Recently, there was an attempt to establish an amortization plan which would eventually purge the city of all non-conforming signs within a limited number of years, however, the city council refused it. Instead they agreed to establish an amortization schedule which will allow all non-conforming signs to remain for a period of ten years, at which time they must be removed. The reasoning for offering such a long-term period is because of the opposition by business owners to a more stringent amortization schedule. It has been speculated that little will change even when the ten-year expiration has arrived. Therefore, much of the problem lies with the city. It has done little to enforce the existing ordinances, and has refused to establish more stringent methods of eliminating those signs which are non-conforming.

Survey Results: Thirteen more residents responded that the existing signage is visually acceptable than those who responded otherwise. Furthermore, less than $40 \%$ stated that the City should improve the existing signage. Approximately 
$62 \%$ of the business owners responded that the number of existing signs was acceptable and $73 \%$ responded that the existing height was fine. Additionally, several business owners commented that little enforcement has allowed unfair signage practices to occur. Therefore, they were prepared to situate non-conforming signs and ignore existing ordinances.

objective: Control haphazard signage.

\section{Recommendations:}

(1) The first action offered is to recommend enforcement of the newly revised Sign Ordinance. This can be accomplished by hiring an enforcement officer who will travel around ensuring that legislation is being followed and fining those who do not. If a recommendation such as this one is not followed, the situation will only get worse and so will relations between the business community and the city.

(2) Eventual elimination of all non-conforming signs can be achieved. Residents and business owners responded that the existing signage was acceptable. Furthermore, the city council has already asserted what their opinion is on behalf of eliminating signs too quickly. Therefore, it is recommended that a slightly more stringent amortization schedule (than the one which was recently approved), be adopted. A schedule can be arranged which will eliminate all signs within the ten-years as originally adopted by the city 
Council, but do so periodically throughout this time-period. Such a schedule would amortize signs based on their age and depreciating value. Therefore, it is recommended that an analysis of commercial signs within the project area be conducted regarding their age and existing value. Once, this has been completed, a schedule can be arranged which will offer all business owners a fair amount of time in which to remove their non-conforming signs.

\section{Subject: City Entrances (Gateways)}

Issues: Due to the odd-configuration of orange city, there are many small unattractive signs which simply designate city limits. The primary entrances, from the north and south of Us Route 17-92, also include rather unappealing signage. The northerly entrance (as previously shown) is simply a wire-mesh gate with various emblems attached. The southerly entrance is just a common public sign stating the city's name.

Survey Results: Sixty-five percent of the residents responded that city entrances need to be improved in order to better promote the city. Furthermore, three individuals stated that the city needs to promote itself in a more effective manner. sixteen percent more business owners responded that City entrances need to be improved in comparison to those who 
answered otherwise. In addition, three business owners commented that the city could better promote itself.

Objective: Enhance the gateway appearance of US Route 17-92 in order to offer a positive first impression to all who enter Orange City as well as promote the City's focal points.

Recommendations:

(1) The existing entrances (gateways) are unacceptable. Therefore, the city should take immediate action towards developing signs for both US Route 17-92, orange City, entrances. The signs should clearly identify the city, its focal points (i.e. Blue Springs Park and the manatee), and perhaps some of its history (e.g. the year it was incorporated). Figure 5.7 offers an examples of how these entrance signs could appear. Regardless of what design is eventually selected, the signs should be of an aesthetically enhancing material, such as wood, and the information it contains well displayed (e.g. engraved or sunken lettering). The remaining signage which identifies the city limits are acceptable. These signs are located, for example, off Enterprise Road and East Graves Avenue. These areas not considered main entry points, and therefore, city identification is all that is required. 
(2) The existing sign which directs drivers towards Blue Springs Park, is also unattractive. It is understood that the Figure 5.7

\section{Visual Representation of a Landscaped City Entrance $\mathbf{B}$ ign}

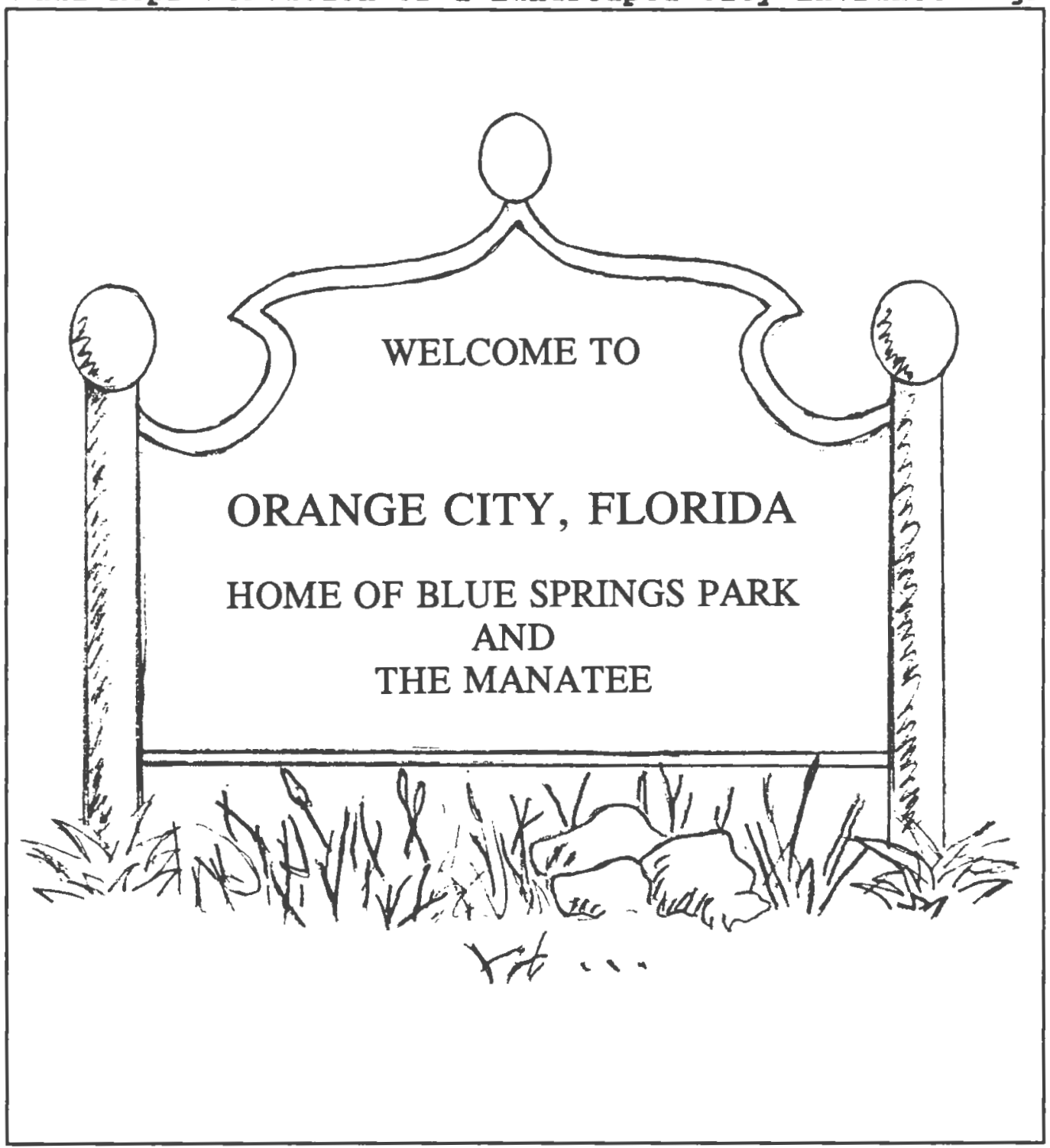

(Source: Nathaniel Cardoso, local amateux graphic artist)

State requires placement of the standard brown colored signage indicating a nearby state Park. Therefore, it is perhaps possible that this required sign could be reduced in size, and 
a second more aesthetically enhancing sign be constructed and placed on a proposed median (island). It is recommended that such a proposal be further investigated for its viability.

\section{Subject: Parking}

Issues: Over $75 \%$ of all US Route 17-92 businesses have some form of unbuffered frontage oriented customer parking. Therefore, this has considerably deterred from the aesthetics as well as the safety of the area. However, neither businesses nor residents seem to perceive this as a problem. The city has commented that as a result of the limited concern presented by businesses and residents, the existing parking situation will continue. An example of this is the newly constructed Target Department store which has its limited landscaped customer parking area in full view of Enterprise Road.

Survey Results: Approximately 17\% of the residents responded negatively towards the existing parking areas. No business responded negatively, and in fact, approximately $27 \%$ stated that they had too little parking.

objective: Improve the visual appearance of commercial parking areas. 
Recommendations:

(1) There are few areas within the project area which can be further developed. However, these remaining areas should be required, through zoning regulations, to orient their parking areas on the side or to the rear of their business. Where plausible, new developments must have their driveways oriented onto side streets, and not directly onto US Route 1792.

(2) Due to the fact that existing parking areas are considered legally non-conforming by zoning standards, there is little the city can do to eliminate them. Therefore, it is recommended that these parking areas be buffered, thereby visually eliminating them from the view of the highway. The placement of berms, hedges, and/or floral arrangements will hide these parking areas while simultaneously enhancing the appearance of the area. Though, the city cannot legally enforce existing businesses to perform this recommendation, they may be able to do so through incentives. The city could offer a tax-break to all businesses who buffer and improve the appearance of their parking lots as well as maintain them.

\section{Subject: Landscaping}

Issues: The project area has little to no landscaping. The reason for this is due to the extensive commercial businesses which exist along US Route 17-92 and the perception that a 
highway requires no landscaping. The city itself can be equally blamed for not enforcing the regulations contained in their "Tree and Landscape Ordinance.

Survey Results: Sixty-eight percent of the residents responded that the project area was overall visually pleasing. However, $14 \%$ more residents stated that there was limited landscaping in comparison to those who responded otherwise. Furthermore, $55 \%$ of the residents asserted that the city should enhance the existing landscape. Business owners were split in their opinion of the visual appearance of the area. However, more than two-to-one responded that the existing landscape was adequate. Furthermore, three business owners commented that US Route $17-92$ is in desperate need of improvement.

objective: Utilize the application of appropriate landscaping materials to soften the hard urbanized features of the area.

Recommendations:

(1) Due to the vast amount of pavement lining both sides of US Route 17-92, there is little which can be altered. Therefore, it is recommended that landscaping be primarily concentrated towards the proposed medians. It is highly recommended that palm trees be the principal landscape 
component. Additionally, grass and a variety of flowers should accompany the trees. Perhaps once this landscape material has been implemented, businesses will be enticed to enhance their own property.

(2) Due to the high costs of constructing the proposed islands and the placement of landscape material, perhaps the City could negotiate some compromise with the state. Such a compromise could entail the city agreeing to maintain the islands for some period of time in exchange for the state agreeing to construct and landscaping the islands.

\section{Subject: street Lighting and Electrical wiring}

Issues: The entire expanse of US Route 17-92 is lighted with street lighting. Furthermore, telephone poles and overhead wiring line the highway. These conditions are contributing to the unappealing visual appearance of the area.

Survey Results: In regards to the existing street lighting, approximately $72 \%$ of the residents responded that it was adequate. On the other hand, $84 \%$ responded that the overhead wiring was unattractive, and thus, should be placed underground. Fifty-two percent of the businesses responded that existing street lighting was adequate and more than twoto-one voted in favor of placing all overhead wiring underground. Additionally, both residents and business owners 
alike commented that overhead wiring is a safety hazard due to the intense storms that constantly bring these power-lines down.

Objectives: Endorse a long-term commitment towards removing all electrical wiring along US Route 1792 and placing it underground.

- Assure that street lighting is adequate to ensure the safety of all pedestrians and drivers.

\section{Recommendations:}

(1) The general opinion is that the existing street lighting is adequate, and several on-site nightly visits further verified this fact. However, several residents and business owners commented that lighting is not readily replaced when needed. Therefore, it is recommended that the Public Works Department periodically make on-site spot-checks of the project area to ensure that all street lighting is in working order. The city should immediately replace any inoperative lighting on City streets, and bring to the attention of the county lighting which is inoperative on those streets classified as county, including us Route 17-92.

(2) Regarding the overhead electrical wiring situation, it is recommended that a study be done to determine the feasibility of placing it underground. Such a proposal would naturally be accomplished over a long period of time due to 
the high costs involved. Nevertheless, if a study is done and a plan prepared, then as repairs are done along US Route 1792, wiring can simultaneously be removed and placed underground. 
${ }^{1}$ Barry D. Lundberg and Charles W. Lustig, "Demand Responsive Transit Service: A New Transportation Tool," Planning Advisory Service, no. 286 (1972): 1.

${ }^{2}$ This can be verified by analyzing the trip generations completed on a sampling of primary bisectors (e.g. Graves is well under the maximum allowable standard). Furthermore, Mr. Milton Moritz has stated that there will be at most a $40-60$ average daily vehicle increase. (Mr. Milton Moritz, orange City Director of Public Works, interview by author, 7 February 1994, orange City, Florida, oral, orange City Town Hall, orange City, Florida.) 
Due to the wide ranging problems which exist along US Route 17-92, a variety of recommendations have been presented. These recommendations are diverse in composition, and thus, their implementation will occur as a result of various sources. The funding, on the other hand, must basically be procured from the county and/or state. US Route 17-92 is under the authority of three different levels of government. US Route 17-92 is primarily a federally designated nighway, but its upkeep has been delegated to the state of Florida (from now on referred to as "state"). In addition, Volusia county (from now on referred to as "County"), has been delegated authority over traffic signals and all signage, from the state. Therefore, implementation of the various recommendations will depend upon the specifics of each recommendation and in whose domain they apply.

\section{ADMINISTRATIVE STRATEGIES}

Traffic oriented

The primary problems affecting US Route 17-92 and orange City in turn are traffic related. These include increasing traffic volumes and automobile accidents. Therefore, the recommendations which have been presented to alter these existing conditions, namely, the construction of landscaped islands and the establishment of specified signalized intersections, must result from the state of Florida Department of Transportation resources. On the other hand, 
the maintenance of the islands can be negotiated. Perhaps, some agreement can be reached, whereby, the city maintains the landscaping and the state the islands. Such an agreement would be worthwhile, especially if this would ensure their construction. Though the placement of islands does not have to occur simultaneously with the proposed highway reconfiguration, such a possibility is welcomed. This would eliminate the need to establish a city-wide coalition to pressure the state into implementing these recommendations. Furthermore, costs would be lowered due to the fact that both proposals would be included as one task.

Should the state decide not to implement these recommendations at the present time, or should these recommendations be too late to be included in the proposed reconfiguration plan, then a city-wide coalition will be required. Such a coalition could be comprised of members from the Orange City Planning Department (e.g. Mr. James Kerr), the Orange City Public Works Department (e.g. Mr. Milton Moritz), City Council members, the Mayor, the City Manager, residents and business owners. The purpose of the coalition would be to promote the suggested recommendations, thereby, persuading the Sate into implementing them. The same coalition could be utilized as oversees to those whom will maintain the islands, should such an arrangement between the city and state occur. Upkeep of the islands as well as Us Route 17-92's appearance (e.g. litter-control), can be accomplished through 
a similar program which has been established in sacramento, California. This program, known as "Adopt-a-Highway", has utilized citizen participation to clean-up roadsides.1 Perhaps the coalition can organize an accessory committee who will administer the maintenance and clean-up of the islands. Regarding the redesignation of side streets from two-way to one-way and the road improvements, the city has the authority to accomplish these tasks. However, there are four sections of roads which need repair and are designated as county streets. Therefore, these repairs must be conducted by the county. The previously mentioned coalition can be useful by influencing, and thus, assuring that these desperately required repairs are accomplished.

\section{Amenities}

Those amenities which are specifically oriented towards the islands (e.g. benches), should be included in the same general development plan negotiated between the city and state. Besides their placement, the state should be required to maintain all amenities to be placed on the islands. The reason for this is because they have the financial means of ensuring their upkeep. The city can be of aid by establishing more police patrols and arranging neighborhood watches (comprised of nearby residents and business owners), which will help to reduce vandalism. 
The remaining amenities (e.g. trash receptacles), can be negotiated between the city and state. Though, Us Route 17-92 and adjacent sidewalks are under the state's authority, some arrangement can be conceived whereby the state constructs and maintains them and the city oversees their upkeep (e.g. removal of litter).

\section{Pedestrian Concerns}

There are two pedestrian components which have been recommended, the construction of islands which is discussed above, and the altering of signalized crossing times. This second component is under the domain of the county, and can readily be accomplished through their authority.

\section{Aesthetics}

Island landscaping, as previously mentioned, must be part of the overall construction plan, thereby, being the responsibility of the state. However, the maintenance could perhaps be a feature which the city could undertake, at least for some period of time.

Parking lot buffering and on-going illegal non-conforming sign removal, are two items which are predominantly in the City's domain. Therefore, the City needs to establish a CodeEnforcement position, whose authority would ensure that future problems are not created and existing illegal non-conformities are removed or dealt with in a swift manner. Businesses which 
are located in the county and contain unappealing signs and parking areas also impact US Route 17-92 and establish an unfair precedent. Though the city has no legal authority, a valid argument can be made that this non-conformity is injuring the pride and spirit of orange city, thereby, making it difficult for any changes to occur. A committee comprised of city and county officials as well as local and county business owners has to be organized in order to discuss this situation. Some strategy can then be devised by which all businesses will be under a similar assortment of regulations, thereby, ensuring their equal treatment. This in turn will prosper a more area-wide appealing appearance. Such a proposal could be accomplished by constructing an overlay zone covering only that section of US Route 17-92 located within the project area. Such an arrangement, however, would have to be well discussed and drafted, due to the fact that two legal entities (orange city and Volusia county) are involved.

\section{FUNDING SOURCES}

Federal

There are two possible sources of federal funding which may be acquired to accomplish the necessary construction and landscaping of the islands. These sources include ISTEA (Intermodal Surface Transportation Efficiency Act) and EDA (Economic Development Administration) grants. Both sources are federally administered through the state. Therefore, 
individual communities are requested to furnish their proposals through the State's Department of Transportation for ISTEA funds and the State's Department of Economic Development for EDA funds. ISTEA funds will probably be more suitable for funding the stated recommendation due to the fact that they are designated for any project involving transportation concerns. However, should existing ISTEA funds be already allocated for existing as well as future projects, then it is advised that this request be placed on the next funding session. EDA funds are specifically offered to those areas which are economically stagnated; a concern that does not currently exist within the project area. However, several businesses have recently left the area, and thus, perhaps an argument could be made that future economic stagnation could be a very real possibility if the area does not resolve its traffic and accident dilemma.

State of Florida

The State of Florida Department of Transportation has an annual Capital Improvement Projects (CIP) Program. Various projects are considered, and then a select few included in a specific year's agenda. Construction of the islands, their landscaping and pedestrian amenities, could possibly be funded through such a source.

Rehabilitation and repair of orange city's and those few select county designated roads may also possibly be funded 
through the CIP. Orange City should investigate this possible source as a means of alleviating such a financial burden.

orange city

There are several possible methods of acquiring the necessary funding for road repairs. The first, and most highly recommended, is to include the road repairs in the City's Capital Improvement Projects (CIP). The previously described four phases outlined the manner in which the streets should be repaired. Therefore, those streets which are included in the first two phases, and thus, require immediate attention, should be included in the five year CIP Proposal. The remaining two phases can be included in a ten to fifteen year CIP proposal.

The second method could involve establishing a special Assessment District for the project area. This legal instrument allows the city to raise the taxes only within the specified area because those residents and businesses located there will primarily benefit from the repairs. The special Assessment would only be in effect until the expenses involved are recouped.

A third method would involve issuing General obligation Bonds. However, before such a funding source can be pursued, voter approval is required. Both residents and business owners made it quite clear that they were positively against increased taxes. Therefore, acquiring the necessary voter 
approval may be somewhat difficult. on the other hand, the city has an excellent rating, and with its tremendous tax base, any bonds acquired would be effortlessly disbursed.

In regards to influencing business owners to buffer their parking areas and enhance the surrounding landscape, the city may consider offering tax breaks or other incentives in exchange for certain specified improvements.

\section{REGULATORY BTRATEGIES}

The newly revised orange city sign ordinance is quite explicit and thorough. However, there are two revisions which can be accomplished in order to further strengthen it. These include; the establishment of a more strict sign amortization schedule, and requesting bonds be posted for temporary signs. This amortization schedule will not only ensure that all nonconforming signs are eliminated within ten years as currently required by the sign ordinance, but also that signs are removed throughout this time-period. This can be accomplished by creating a schedule which requires the removal of signs based upon their age and depreciating value, thereby protecting the financial expenses that owners have invested into these signs. By demanding that a bond be posted each time a temporary sign is requested, the city will assure the removal of these signs by the owner at an appropriate expiration period. Both recommendations will ensure the aesthetic enhancement of the project area as well as appease 
those business owners who feel that an unfair precedent is being set. It is well understood that both these ideas have been previously suggested and denied by the city council. Therefore, perhaps once other recommendations have been implemented and completed these ideas can be reevaluated.

strict enforcement of landscaping requirements for all future commercial developments must occur. In addition, it should be required within the zoning ordinance that future frontage oriented parking areas be buffered. This will still allow viewing from the highway, but at a reduced level.

The area requiring strict regulation enforcement will be throughout the proposed West Volusia Beltline. Either an overlay zone should be immediately imposed upon the entire area, or strict design guidelines established which will impact developments throughout the Beltline corridor. Whichever method is selected, it should be immediately enacted that driveway cuts onto the Beltline will be prohibited. Furthermore, any future developments must establish access onto the Beltline via a side street or a frontage road. In fact, it is highly recommended that developments be planned utilizing the Planned Unit Development concept, thereby, ensuring fewer curb-cuts. 
${ }^{1}$ Sandy Harrison, "Adopt-a-Highway program a success," Daily News - Sacramento Bureau, 2 November 1992, (Page No. Unknown) . 
A P P E N D I X 
TABle A. 1

TRAFFIC ANALYSIS AND LEVEL OF SERVICE

\begin{tabular}{|c|c|c|c|c|c|c|c|c|c|c|c|c|c|}
\hline GTREET NAME & $\begin{array}{c}\text { LIMIT8: } \\
\text { FROM - TO } \\
\text { OY } \\
\text { LOCATION OF } \\
\text { COUNT } \\
\text { BTATION (LOC) }\end{array}$ & $\begin{array}{l}\text { TRAVEL } \\
\text { DIRECT. }\end{array}$ & $\begin{array}{l}1988 \\
\text { ADT }\end{array}$ & $\begin{array}{l}1989 \\
\text { ADT }\end{array}$ & $\begin{array}{l}1990 \\
\text { ADT }\end{array}$ & $\begin{array}{l}1991 \\
\text { ADT } 6 \\
\text { LOS }\end{array}$ & $\begin{array}{l}1992 \\
\text { ADT LOS }\end{array}$ & $\begin{array}{l}1993 \\
\text { ADT \& LOB }\end{array}$ & $\begin{array}{l}\text { ALLOW. } \\
\text { LOB IN } \\
\text { COMP. } \\
\text { PLAN }\end{array}$ & $\begin{array}{l}\text { MAX. } \\
\text { CAP AT } \\
\text { ALLOW. } \\
\text { LOB }\end{array}$ & & $\begin{array}{l}\text { ODIC GR } \\
\text { CINANGE } \\
3 \text { 90-93 }\end{array}$ & $\sum_{2-93}^{\text {SOWTI }}$ \\
\hline $\begin{array}{l}\text { East Graves Ave } \\
\text { (Eastbound) }\end{array}$ & $\begin{array}{l}\text { (LOC) } \\
\text { East of } \\
\text { US } 17-92\end{array}$ & West & 4,958 & 5,132 & 4,371 & 5,007 & $5,013 \quad D$ & $4,980 \quad \mathrm{D}$ & $\mathbf{E}$ & 6,246 & $.44 \%$ & $13.9 \%$ & $.06 \%$ \\
\hline $\begin{array}{l}\text { East Graves Ave } \\
\text { (Westbound) }\end{array}$ & $\begin{array}{l}\text { (LOC) } \\
\text { East of } \\
\text { US } 17-92\end{array}$ & East & 4,404 & 4,792 & 5,062 & 4,678 & $4,694 \quad \mathrm{D}$ & $4,839 \quad \mathrm{D}$ & $\mathbf{E}$ & 6,246 & $9.9 \pi$ & $-4.4 \pi$ & $3.1 \%$ \\
\hline Enterprise Rd & $\begin{array}{l}\text { (LOC) South of } \\
\text { Saxon Blvd }\end{array}$ & $\mathrm{N}+\mathrm{S}$ & 12,542 & 13,302 & 14,309 & 16,051 & $16,037 \mathrm{C}$ & $19,567 \quad \mathrm{D}$ & E & 24,700 & $56.0 x$ & $36.7 \%$ & $22.0 \%$ \\
\hline $\begin{array}{l}\text { Enterprise Rd } \\
\text { (Northbound) }\end{array}$ & $\begin{array}{l}\text { (LOC) North of } \\
\text { Saxon Blvd }\end{array}$ & North & 11,725 & 11,629 & 10,909 & 11,079 & $10,681 \quad \mathrm{~B}$ & $12,272 \quad B$ & E & 25,100 & $4.6 \%$ & $12.5 \%$ & $14.9 \%$ \\
\hline $\begin{array}{l}\text { Enterprise Rd } \\
\text { (Southbound) }\end{array}$ & $\begin{array}{l}\text { (LOC) North of } \\
\text { Saxon Blvd }\end{array}$ & South & 11,435 & 11,5055 & 11,124 & 11,451 & $11,209 \quad \mathrm{~B}$ & $12,685 \quad \mathrm{~B}$ & E & 25,100 & $10.9 \%$ & $14.0 \%$ & $13.1 \%$ \\
\hline $\begin{array}{l}\text { Enterprise Rd } \\
\text { (Northbound) }\end{array}$ & $\begin{array}{l}\text { (LOC) } \\
\text { South of } \\
\text { Gr. Plaza Dr }\end{array}$ & North & 10,775 & 10,857 & 10,403 & 11,117 & $10,973 \quad$ B & $12,507 \quad \mathrm{~B}$ & $\mathbf{E}$ & 25,100 & $16.0 \%$ & $20.2 \%$ & $14.0 \%$ \\
\hline $\begin{array}{l}\text { Enterprise Rd } \\
\text { (Southbound) }\end{array}$ & $\begin{array}{l}(L O C) \\
\text { South of } \\
\text { Gr. Plaza Dr }\end{array}$ & South & 10,305 & 10,930 & 10,403 & 10,582 & $11,028 \quad B$ & $11,577 \quad \mathrm{~B}$ & E & 25,100 & $12.3 \%$ & $11.3 \%$ & $5.0 \%$ \\
\hline $\begin{array}{l}\text { Enterprise Rd } \\
\text { (Northbound) }\end{array}$ & $\begin{array}{l}\text { (LOC) } \\
\text { South of } \\
\text { US } 17-92\end{array}$ & North & 9,394 & 9,423 & 9,792 & 10,466 & $10,716 \quad \mathrm{~B}$ & $11,358 \quad \mathrm{~B}$ & $E$ & 25,100 & $20.9 \%$ & $16.0 \%$ & $6.0 \%$ \\
\hline $\begin{array}{l}\text { Enterprise Rd } \\
\text { (Southbound) }\end{array}$ & $\begin{array}{l}\text { (LOC) } \\
\text { South of } \\
\text { US } 17-92\end{array}$ & South & 10,888 & 11,233 & 9,414 & 10,275 & $10,822 \quad B$ & $11,276 \quad B$ & $E$ & 25,100 & $3.5 \%$ & $19.8 \%$ & $4.2 \%$ \\
\hline French Ave & $\begin{array}{l}\text { (LOC) } \\
\text { West of } \\
\text { US } 17-92\end{array}$ & $E+W$ & 4,221 & 3,835 & 3,383 & 3,825 & $3,728 \quad A$ & $3,727 \quad \mathrm{~A}$ & $\mathrm{E}$ & 11,390 & $-11.7 \%$ & $10.1 \%$ & $.02 x$ \\
\hline Minnesota Ave & $\begin{array}{l}\text { (LOC) } \\
\text { West of } \\
\text { US } 17-92\end{array}$ & $E+W$ & 1,385 & 1,565 & 1,632 & 1,408 & $1,852 \quad \mathrm{~A}$ & $1,895 \quad \mathrm{~A}$ & E & 11,390 & $36.8 \%$ & $16.1 \%$ & $2.3 x$ \\
\hline
\end{tabular}




\begin{tabular}{|c|c|c|c|c|c|c|c|c|c|c|c|c|c|}
\hline BTREET NAME & $\begin{array}{c}\text { LIMITS: } \\
\text { FROM - TO } \\
\text { OI } \\
\text { LOCATION OF } \\
\text { COUNT } \\
\text { BTATION (LOC) }\end{array}$ & $\begin{array}{l}\text { TRAVEL } \\
\text { DIRECT. }\end{array}$ & $\begin{array}{l}1988 \\
\text { ADT }\end{array}$ & $\begin{array}{l}1989 \\
\text { ADT }\end{array}$ & $\begin{array}{l}1990 \\
\text { ADT }\end{array}$ & $\begin{array}{l}1991 \\
\text { ADT } \\
\text { LOS }\end{array}$ & $\begin{array}{l}1992 \\
\text { ADT \& LOB }\end{array}$ & $\begin{array}{l}1993 \text { ADT \& LOB }\end{array}$ & $\begin{array}{l}\text { ALLOW. } \\
\text { LOB IN } \\
\text { COMP. } \\
\text { PLAN }\end{array}$ & $\begin{array}{l}\text { MAX. } \\
\text { CAP AT } \\
\text { ALLOW. } \\
\text { LOS }\end{array}$ & $\begin{array}{r}\text { PFiRI } \\
C \\
\text { C }\end{array}$ & $\begin{array}{l}\text { OHIC GR } \\
\text { IIINGE } \\
390.93\end{array}$ & 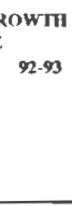 \\
\hline Minnesota Ave & $\begin{array}{l}\text { (LOC) } \\
\text { East of } \\
\text { US } 17-92\end{array}$ & $E+W$ & 1,120 & 1,074 & 1,280 & 1,134 & $1,348 \quad A$ & $1,600 \quad \mathrm{~A}$ & $\mathbf{E}$ & 11,390 & $42.8 \%$ & $25.0 \%$ & $18.7 \%$ \\
\hline Saxon Blvd & $\begin{array}{l}\text { (LOC) } \\
\text { West of } \\
\text { Enterprise Rd }\end{array}$ & $E+W$ & 6,731 & 7,126 & 8,542 & 9,443 & $10,184 \quad \mathrm{~B}$ & $9,207 \quad \mathrm{~B}$ & $\mathbf{E}$ & 24,700 & $36.8 \%$ & $7.8 \%$ & $-9.6 \%$ \\
\hline Saxon Blvd & $\begin{array}{l}\text { (LOC) } \\
\text { East of } \\
\text { Enterprise Rd }\end{array}$ & $E+W$ & 14,484 & 17,521 & 18,883 & 19,753 & $19,240 \quad \mathrm{~B}$ & $20,303 \quad \mathrm{~B}$ & $\mathbf{E}$ & 50,200 & $40.1 \%$ & $7.5 \%$ & $5.5 \pi$ \\
\hline W. New York Ave & $\begin{array}{l}\text { (LOC) } \\
\text { West of } \\
\text { Carpenter Ave }\end{array}$ & $E+W$ & 2,580 & 2,677 & 2,776 & 2,971 & $3,348 \quad \mathrm{~A}$ & $3,460 \quad A$ & $E$ & 11,390 & $34.1 \%$ & $24.6 \%$ & $3.3 \%$ \\
\hline พ. New York Ave & $\begin{array}{l}\text { (LOC) } \\
\text { West of } \\
\text { US } 17-92\end{array}$ & $E+W$ & 3,145 & 3,192 & 3,496 & 3,546 & $4,027 \quad A$ & $4,312 \quad A$ & $\mathrm{E}$ & 11,390 & $37.1 \%$ & $23.3 \%$ & $7.0 \%$ \\
\hline
\end{tabular}

\begin{tabular}{|c|c|c|c|c|c|c|c|c|c|c|c|c|c|c|}
\hline 8TREET & NAME & $\begin{array}{l}\text { LIMIT8: FROM - TO } \\
\text { Or } \\
\text { LOCATION OF COUNT } \\
\text { STATION (LOC) }\end{array}$ & $\begin{array}{l}\text { TRAVEL } \\
\text { DIRECT. }\end{array}$ & $\begin{array}{l}1978 \\
\text { ADT }\end{array}$ & $\begin{array}{l}1989 \\
\text { ADT }\end{array}$ & $\begin{array}{l}1990 \\
\text { ADT }\end{array}$ & $\begin{array}{l}1991 \\
\text { ADT }\end{array}$ & $\begin{array}{l}1992 \\
A D T \& L O 8\end{array}$ & $\begin{array}{l}\text { ALLOW. } \\
\text { LOS IN } \\
\text { COMP. } \\
\text { PLAN }\end{array}$ & $\begin{array}{l}\text { MAX. } \\
\text { CAP AT } \\
\text { ALLOF. } \\
\text { LOB }\end{array}$ & \multicolumn{4}{|c|}{$\begin{array}{l}\text { PERUODIC GROWTH } \\
\text { CHANGE } \\
\begin{array}{c}99.92 \\
90.92\end{array} 91-92\end{array}$} \\
\hline $\begin{array}{l}\text { US ROUTE } 1 \\
\text { (Volusia } \mathrm{A}\end{array}$ & $\begin{array}{l}17-92 \\
\text { Avenue) }\end{array}$ & $\begin{array}{l}\text { Enterprise Rd to } \\
\text { Blue Springs Ave }\end{array}$ & $N+S$ & 12,911 & 35,009 & 39,429 & 37,600 & $35,000 \quad F$ & $c$ & 29,100 & $171.0 \%$ & $-0.02 x$ & $.11 .2 \%$ & $5.9 \%$ \\
\hline $\begin{array}{l}\text { US ROUTE } 1 \\
\text { (Volusia } \mathrm{A}\end{array}$ & $\begin{array}{l}17-92 \\
\text { Avenue) }\end{array}$ & $\begin{array}{l}\text { Blue Springs Ave } \\
\text { to Graves Ave }\end{array}$ & $N+S$ & 15,615 & 31,135 & 29,849 & 27,900 & $34,000 \quad F$ & c & 29,100 & $117.7 \pi$ & $9.20 \%$ & $13.9 \%$ & $21.8 \%$ \\
\hline $\begin{array}{l}\text { US ROUTE } 1 \\
\text { (Volusia A }\end{array}$ & $\begin{array}{l}17-92 \\
\text { Avenue) }\end{array}$ & $\begin{array}{l}\text { Graves Ave to } \\
\text { French Ave }\end{array}$ & $N+S$ & 15,897 & 28,403 & 30,567 & 30,600 & $27,500 \quad c$ & $\mathrm{C}$ & 29,100 & $73.0 \%$ & $-3.20 \%$ & $-10.0 \%$ & $-10.1 x$ \\
\hline $\begin{array}{c}\text { US ROUTE } 1 \\
\text { (Volusia } \mathrm{A}\end{array}$ & $\begin{array}{l}\text { 17-92 } \\
\text { Avenue) }\end{array}$ & $\begin{array}{l}\text { French Ave to } \\
\text { State Rte } 472\end{array}$ & $N+S$ & 12,647 & 28,678 & 30,702 & 30,600 & $30,500 \quad \mathrm{D}$ & C & 29,100 & $141.1 \%$ & $6.30 \%$ & $0.66 \%$ & $-0.3 \%$ \\
\hline
\end{tabular}

(Source: Bill Linkovich of the Florida Department of Transportation, DeLand, Florida) 
TABLE A.2

U8 ROUTE 17-92 ACCIDENT STATIBTICB: 1987 - 1989

\begin{tabular}{|c|c|c|c|c|}
\hline LOCATION & $\begin{array}{c}\text { NUKBER } \\
\text { OF } \\
\text { ACCIDENTS }\end{array}$ & $\begin{array}{l}\text { NUMBER } \\
\text { INJURED }\end{array}$ & $\begin{array}{l}\text { NUMBER } \\
\text { KILLED }\end{array}$ & $\begin{array}{c}\text { NEARBY } \\
\text { INTERSECTION } \\
\text { INFLUENCING } \\
\text { FACTOR }\end{array}$ \\
\hline $\begin{array}{l}\text { Intersection of Enterprise } \\
\text { Road }\end{array}$ & 5 & 9 & 0 & Not Applicable \\
\hline $\begin{array}{l}\text { Between Enterprise Road } \\
\text { and Roberts Street }\end{array}$ & 15 & 23 & 0 & 6 \\
\hline $\begin{array}{l}\text { Between Roberts street } \\
\text { and Iris Drive }\end{array}$ & 4 & 3 & 0 & 2 \\
\hline $\begin{array}{l}\text { Between Iris Drive } \\
\text { and w. Holly Drive }\end{array}$ & 2 & 6 & 0 & 1 \\
\hline $\begin{array}{l}\text { Between w. Holly Drive } \\
\text { and E. Holly Drive }\end{array}$ & 4 & 6 & 0 & 4 \\
\hline $\begin{array}{l}\text { Between E. Holly Drive } \\
\text { and E. Gardenia Drive }\end{array}$ & 1 & 0 & 0 & 0 \\
\hline $\begin{array}{l}\text { Between E. Gardenia Drive } \\
\text { and Fern Drive }\end{array}$ & 3 & 1 & 0 & 2 \\
\hline $\begin{array}{l}\text { Between Fern Drive } \\
\text { and Elm Drive }\end{array}$ & 3 & 2 & 0 & 1 \\
\hline $\begin{array}{l}\text { Between Elm Drive } \\
\text { and Dogwood Avenue }\end{array}$ & 1 & 1 & 0 & 0 \\
\hline $\begin{array}{l}\text { Intersection of } \\
\text { Dogwood Avenue }\end{array}$ & 7 & 6 & 0 & Not Applicable \\
\hline $\begin{array}{l}\text { Between Dogwood Avenue } \\
\text { and Cedar Avenue }\end{array}$ & 5 & 4 & 0 & 2 \\
\hline $\begin{array}{l}\text { Intersection of } \\
\text { Birch Avenue }\end{array}$ & 4 & 7 & 0 & Not Applicable \\
\hline $\begin{array}{l}\text { Intersection of } \\
\text { Aspen Avenue }\end{array}$ & 3 & 4 & 0 & Not Applicable \\
\hline $\begin{array}{l}\text { Between Aspen Avenue } \\
\text { and Rhode Island Avenue }\end{array}$ & 3 & 3 & 0 & 1 \\
\hline $\begin{array}{l}\text { Between Rhode Island Avenue } \\
\text { and } \mathrm{S} \text {. Industrial Drive }\end{array}$ & 2 & 0 & 0 & 1 \\
\hline $\begin{array}{l}\text { Between Highland Avenue } \\
\text { and N. Industrial Drive }\end{array}$ & 3 & 2 & 0 & 3 \\
\hline $\begin{array}{l}\text { Intersection of } \\
\text { N. Industrial Drive }\end{array}$ & 7 & 10 & 0 & Not Applicable \\
\hline
\end{tabular}




\begin{tabular}{|c|c|c|c|c|}
\hline LOCATION & $\begin{array}{c}\text { NUMBER } \\
\text { OF } \\
\text { ACCIDENTS }\end{array}$ & $\begin{array}{l}\text { NOMBER } \\
\text { INJURED }\end{array}$ & $\begin{array}{l}\text { NOMBER } \\
\text { KILLED }\end{array}$ & $\begin{array}{c}\text { NEARBY } \\
\text { INTERBECTION } \\
\text { INFLUENCING } \\
\text { FACTOR }\end{array}$ \\
\hline $\begin{array}{l}\text { Between N. Industrial Drive } \\
\text { and Ohio Avenue }\end{array}$ & 8 & 12 & 0 & 2 \\
\hline $\begin{array}{l}\text { Intersection of } \\
\text { Ohio Avenue }\end{array}$ & 16 & 14 & 0 & 0 \\
\hline $\begin{array}{l}\text { Between Ohio Avenue } \\
\text { and Brooklyn Avenue }\end{array}$ & 2 & 2 & 0 & 1 \\
\hline $\begin{array}{l}\text { Intersection of } \\
\text { Brooklyn Avenue }\end{array}$ & 2 & 3 & 0 & Not Applicable \\
\hline $\begin{array}{l}\text { Intersection of } \\
\text { W. Virginia Avenue }\end{array}$ & 7 & 7 & 0 & Not Applicable \\
\hline $\begin{array}{l}\text { Between w. Virginia Avenue } \\
\text { and "A" street }\end{array}$ & 4 & 4 & 0 & 2 \\
\hline $\begin{array}{l}\text { Between "A" Street } \\
\text { and Blue Springs Avenue }\end{array}$ & 1 & 1 & 0 & 1 \\
\hline $\begin{array}{l}\text { Intersection of } \\
\text { Blue Springs Avenue }\end{array}$ & 14 & 8 & 0 & Not Applicable \\
\hline $\begin{array}{l}\text { Between Blue Springs Avenue } \\
\text { and Banana Avenue }\end{array}$ & 4 & 7 & 0 & 2 \\
\hline $\begin{array}{l}\text { Intersection of } \\
\text { Banana Avenue }\end{array}$ & 1 & 1 & 0 & Not Applicable \\
\hline $\begin{array}{l}\text { Between Banana Avenue } \\
\text { and E. Rose Avenue }\end{array}$ & 1 & 3 & 0 & 0 \\
\hline $\begin{array}{l}\text { Intersection of } \\
\text { E. Rose Avenue }\end{array}$ & 1 & 2 & 0 & Not Applicable \\
\hline $\begin{array}{l}\text { Between } \mathrm{E} \text {. Rose Avenue } \\
\text { and Cherokee Avenue }\end{array}$ & 1 & 1 & 0 & 0 \\
\hline $\begin{array}{l}\text { Between Cherokee Avenue } \\
\text { and Albertus Avenue }\end{array}$ & 1 & 1 & 0 & 0 \\
\hline $\begin{array}{l}\text { Between Albertus Avenue } \\
\text { and Graves Avenue }\end{array}$ & 1 & 0 & 0 & 0 \\
\hline $\begin{array}{l}\text { Intersection of } \\
\text { Graves Avenue }\end{array}$ & 17 & 6 & 0 & Not Applicable \\
\hline $\begin{array}{l}\text { Between Graves Avenue } \\
\text { and Central Avenue }\end{array}$ & 3 & 8 & 0 & 1 \\
\hline $\begin{array}{l}\text { Between Central Avenue } \\
\text { and University Avenue }\end{array}$ & 1 & 1 & 0 & 0 \\
\hline
\end{tabular}




\begin{tabular}{||l|l|l|l|l||}
\hline \multicolumn{1}{|c|}{ LOCATION } & $\begin{array}{c}\text { NUMBER } \\
\text { OF } \\
\text { ACCIDENTS }\end{array}$ & $\begin{array}{l}\text { NUMBER } \\
\text { INJURED }\end{array}$ & $\begin{array}{l}\text { NUMBER } \\
\text { KILLED }\end{array}$ & $\begin{array}{c}\text { NEARBY } \\
\text { INTERBECTION } \\
\text { INFLUENCING } \\
\text { FACTOR }\end{array}$ \\
\hline $\begin{array}{l}\text { Intersection of } \\
\text { University Avenue }\end{array}$ & 3 & 5 & 0 & Not Applicable \\
\hline $\begin{array}{l}\text { Between University Avenue } \\
\text { and French Avenue }\end{array}$ & 2 & 4 & 0 & 1 \\
\hline $\begin{array}{l}\text { Intersection of } \\
\text { French Avenue }\end{array}$ & 14 & 16 & 0 & Not Applicable \\
\hline $\begin{array}{l}\text { Between French Avenue } \\
\text { and May Street }\end{array}$ & 2 & 4 & 0 & 0 \\
\hline $\begin{array}{l}\text { Intersection of } \\
\text { May Street }\end{array}$ & 2 & 0 & 0 & Not Applicable \\
\hline $\begin{array}{l}\text { Between Lansdowne Avenue } \\
\text { and Lee Avenue }\end{array}$ & 1 & 1 & 0 & 0 \\
\hline $\begin{array}{l}\text { Intersection of } \\
\text { Lee Avenue }\end{array}$ & 3 & 1 & 0 & Not Applicable \\
\hline $\begin{array}{l}\text { Between Lee Avenue } \\
\text { and Wisconsin Avenue }\end{array}$ & 3 & 6 & 0 & 1 \\
\hline $\begin{array}{l}\text { Intersection of } \\
\text { Wisconsin Avenue }\end{array}$ & 5 & 3 & 0 & Not Applicable \\
\hline & & & & \\
\hline
\end{tabular}


TABLE A.3

US ROUTE 17-92 ACCIDENT STATISTICS: 1990 - 1991

\begin{tabular}{|c|c|c|c|c|}
\hline LOCATION & $\begin{array}{c}\text { NUMBER } \\
\text { OF } \\
\text { ACCIDENTS }\end{array}$ & $\begin{array}{l}\text { NUMBER } \\
\text { INJURED }\end{array}$ & $\begin{array}{l}\text { NUMBER } \\
\text { KILLED }\end{array}$ & $\begin{array}{c}\text { WAS NEARBY } \\
\text { INTERBECTION } \\
\text { AN INFLUENCING } \\
\text { FACTOR } \\
\end{array}$ \\
\hline $\begin{array}{l}\text { South of } \\
\text { Enterprise Road }\end{array}$ & 2 & 4 & 0 & 2 \\
\hline $\begin{array}{l}\text { Intersection of Enterprise } \\
\text { Road }\end{array}$ & 8 & 15 & 0 & Not Applicable \\
\hline $\begin{array}{l}\text { Between Enterprise Road } \\
\text { and Roberts street }\end{array}$ & 1 & 1 & 0 & 0 \\
\hline $\begin{array}{l}\text { Intersection of } \\
\text { Roberts Street }\end{array}$ & 4 & 6 & 0 & Not Applicable \\
\hline $\begin{array}{l}\text { Between Roberts Street } \\
\text { and Iris Drive }\end{array}$ & 1 & 1 & 0 & 0 \\
\hline $\begin{array}{l}\text { Intersection of } \\
\text { Iris Drive }\end{array}$ & 2 & 2 & 0 & Not Applicable \\
\hline $\begin{array}{l}\text { Intersection of } \\
\text { W. Holly Drive }\end{array}$ & 1 & 1 & 0 & 0 \\
\hline $\begin{array}{l}\text { Between E. Holly Drive } \\
\text { and E. Gardenia Drive }\end{array}$ & 1 & 0 & 0 & 0 \\
\hline $\begin{array}{l}\text { Intersection of } \\
\text { E. Gardenia Drive }\end{array}$ & 5 & 4 & 0 & Not Applicable \\
\hline $\begin{array}{l}\text { Between Fern Drive } \\
\text { and Elm Drive }\end{array}$ & 1 & 1 & 0 & 1 \\
\hline $\begin{array}{l}\text { Intersection of } \\
\text { Elm Drive }\end{array}$ & 1 & 2 & 0 & Not Applicable \\
\hline $\begin{array}{l}\text { Between Elm Drive } \\
\text { and Dogwood Avenue }\end{array}$ & 1 & 2 & 0 & 0 \\
\hline $\begin{array}{l}\text { Intersection of } \\
\text { Dogwood Avenue }\end{array}$ & 3 & 3 & 0 & Not Applicable \\
\hline $\begin{array}{l}\text { Intersection of } \\
\text { Cedar Avenue }\end{array}$ & 3 & 3 & 0 & Not Applicable \\
\hline $\begin{array}{l}\text { Between Cedar Avenue } \\
\text { and Birch Avenue }\end{array}$ & 1 & 2 & 0 & 0 \\
\hline $\begin{array}{l}\text { Between Birch Avenue } \\
\text { and Aspen Avenue }\end{array}$ & 1 & 1 & 0 & 0 \\
\hline
\end{tabular}




\begin{tabular}{|c|c|c|c|c|}
\hline LOCATION & $\begin{array}{c}\text { NUMBER } \\
\text { OF } \\
\text { ACCIDENTS }\end{array}$ & $\begin{array}{l}\text { NUMBER } \\
\text { INJURED }\end{array}$ & $\begin{array}{l}\text { NUMBER } \\
\text { KILLED }\end{array}$ & $\begin{array}{c}\text { WAS NEARBY } \\
\text { INTERSECTION } \\
\text { AN INFLOENCING } \\
\text { FACTOR } \\
\end{array}$ \\
\hline $\begin{array}{l}\text { Between Aspen Avenue } \\
\text { and Rhode Island Avenue }\end{array}$ & 1 & 2 & 0 & 0 \\
\hline $\begin{array}{l}\text { Intersection of } \\
\text { Rhode Island Avenue }\end{array}$ & 1 & 1 & 0 & Not Applicable \\
\hline $\begin{array}{l}\text { Intersection of } \\
\text { S. Industrial Drive }\end{array}$ & 1 & 0 & 0 & Not Applicable \\
\hline $\begin{array}{l}\text { Intersection of } \\
\text { Highland Avenue }\end{array}$ & 1 & 0 & 0 & Not Applicable \\
\hline $\begin{array}{l}\text { Between Highland Avenue } \\
\text { and N. Industrial Drive }\end{array}$ & 1 & 3 & 0 & 0 \\
\hline $\begin{array}{l}\text { Intersection of } \\
\text { N. Industrial Drive }\end{array}$ & 4 & 8 & 0 & Not Applicable \\
\hline $\begin{array}{l}\text { Between N. Industrial Drive } \\
\text { and Ohio Avenue }\end{array}$ & 3 & 3 & 0 & 0 \\
\hline $\begin{array}{l}\text { Intersection of } \\
\text { Ohio Avenue }\end{array}$ & 13 & 18 & 0 & Not Applicable \\
\hline $\begin{array}{l}\text { Between Ohio Avenue } \\
\text { and Brooklyn Avenue }\end{array}$ & 1 & 1 & 0 & 0 \\
\hline $\begin{array}{l}\text { Intersection of } \\
\text { Brooklyn Avenue }\end{array}$ & 1 & 1 & 0 & Not Applicable \\
\hline $\begin{array}{l}\text { Intersection of } \\
\text { "C" street }\end{array}$ & 2 & 5 & 0 & Not Applicable \\
\hline $\begin{array}{l}\text { Between "C" Street } \\
\text { and w. virginia Avenue }\end{array}$ & 1 & 2 & 0 & 0 \\
\hline $\begin{array}{l}\text { Between W. Virginia Avenue } \\
\text { and "A" Street }\end{array}$ & 1 & 1 & 0 & 0 \\
\hline $\begin{array}{l}\text { Intersection of } \\
\text { "A" Street }\end{array}$ & 2 & 3 & 0 & Not Applicable \\
\hline $\begin{array}{l}\text { Intersection of } \\
\text { Blue Springs Avenue }\end{array}$ & 8 & 12 & 0 & Not Applicable \\
\hline $\begin{array}{l}\text { Between Blue Springs Avenue } \\
\text { and Banana Avenue }\end{array}$ & 1 & 4 & 0 & 0 \\
\hline $\begin{array}{l}\text { Between E. Rose Avenue } \\
\text { and Cherokee Avenue }\end{array}$ & 2 & 2 & 0 & 1 \\
\hline $\begin{array}{l}\text { Intersection of } \\
\text { Cherokee Avenue }\end{array}$ & 2 & 2 & 0 & Not Applicable \\
\hline
\end{tabular}




\begin{tabular}{|c|c|c|c|c|}
\hline LOCATION & $\begin{array}{c}\text { NUMBER } \\
\text { OF } \\
\text { ACCIDENTS }\end{array}$ & $\begin{array}{l}\text { NUMBER } \\
\text { INJURED }\end{array}$ & $\begin{array}{l}\text { NOMBER } \\
\text { RILLED }\end{array}$ & $\begin{array}{l}\text { WAS NEARBY } \\
\text { INTERSECTION } \\
\text { AN INFLUENCING } \\
\text { FACTOR } \\
\end{array}$ \\
\hline $\begin{array}{l}\text { Between Cherokee Avenue } \\
\text { and Albertus Avenue }\end{array}$ & 1 & 0 & 0 & 1 \\
\hline $\begin{array}{l}\text { Intersection of } \\
\text { Albertus Avenue }\end{array}$ & 2 & 2 & 0 & 0 \\
\hline $\begin{array}{l}\text { Intersection of } \\
\text { Graves Avenue }\end{array}$ & 9 & 11 & 0 & Not Applicable \\
\hline $\begin{array}{l}\text { Intersection of } \\
\text { Central Avenue }\end{array}$ & 1 & 3 & 0 & Not Applicable \\
\hline $\begin{array}{l}\text { Intersection of } \\
\text { French Avenue }\end{array}$ & 4 & 4 & 0 & Not Applicable \\
\hline $\begin{array}{l}\text { Intersection of } \\
\text { May Street }\end{array}$ & 1 & 0 & 0 & Not Applicable \\
\hline $\begin{array}{l}\text { Intersection of } \\
\text { Lansdowne Avenue }\end{array}$ & 1 & 0 & 0 & Not Applicable \\
\hline $\begin{array}{l}\text { Between Lee Avenue } \\
\text { and Wiscons in Avenue }\end{array}$ & 1 & 1 & 0 & 0 \\
\hline $\begin{array}{l}\text { Intersection of } \\
\text { Wisconsin Avenue }\end{array}$ & 3 & 9 & 0 & Not Applicable \\
\hline $\begin{array}{l}\text { Between Wisconsin Avenue } \\
\text { and New York Avenue }\end{array}$ & 2 & 4 & 0 & 0 \\
\hline $\begin{array}{l}\text { Intersection of } \\
\text { New York Avenue }\end{array}$ & 5 & 13 & 0 & Not Applicable \\
\hline $\begin{array}{l}\text { Between New York Avenue } \\
\text { and St. Lawrence Avenue }\end{array}$ & 4 & 4 & 1 & 0 \\
\hline $\begin{array}{l}\text { Intersection of } \\
\text { St. Lawrence Avenue }\end{array}$ & 3 & 12 & 0 & Not Applicable \\
\hline $\begin{array}{l}\text { Between St. Lawrence Avenue } \\
\text { and Sherman street }\end{array}$ & 3 & 7 & 0 & 0 \\
\hline $\begin{array}{l}\text { Between Sherman Street } \\
\text { and Minnesota Avenue }\end{array}$ & 1 & 1 & 0 & 0 \\
\hline $\begin{array}{l}\text { Intersection of } \\
\text { Minnesota Avenue }\end{array}$ & 6 & 8 & 0 & Not Applicable \\
\hline $\begin{array}{l}\text { Between Minnesota Avenue } \\
\text { and Michigan Avenue }\end{array}$ & 3 & 3 & 0 & 0 \\
\hline TOTAL: & 132 & 198 & 1 & 5 \\
\hline
\end{tabular}


TABLE A. 4

US ROUTE 17-92 ACCIDENT STATISTICS: 1992

\begin{tabular}{|c|c|c|c|c|}
\hline LOCATION & $\begin{array}{c}\text { NUMBER } \\
\text { OF } \\
\text { ACCIDENTS }\end{array}$ & $\begin{array}{l}\text { NUMBER } \\
\text { INJURED }\end{array}$ & $\begin{array}{l}\text { NOMBER } \\
\text { RILLED }\end{array}$ & $\begin{array}{c}\text { WAS NEARBY } \\
\text { INTERSECTION } \\
\text { AN INFLUENCING } \\
\text { FACTOR } \\
\end{array}$ \\
\hline $\begin{array}{l}\text { Intersection of } \\
\text { Enterprise Road }\end{array}$ & 4 & 7 & 0 & Not Applicable \\
\hline $\begin{array}{l}\text { Intersection of } \\
\text { Roberts street }\end{array}$ & 3 & 5 & 0 & Not Applicable \\
\hline $\begin{array}{l}\text { Between Roberts Street } \\
\text { and Iris Drive }\end{array}$ & 1 & 1 & 0 & 0 \\
\hline $\begin{array}{l}\text { Intersection of } \\
\text { Iris Drive }\end{array}$ & 3 & 6 & 0 & Not Applicable \\
\hline $\begin{array}{l}\text { Intersection of } \\
\text { W. Holly Drive }\end{array}$ & 1 & 1 & 0 & Not Applicable \\
\hline $\begin{array}{l}\text { Between W. Holly Drive } \\
\text { and E. Holly Drive }\end{array}$ & 1 & 1 & 0 & 0 \\
\hline $\begin{array}{l}\text { Intersection of } \\
\text { Gardenia Drive }\end{array}$ & 1 & 1 & 0 & Not Applicable \\
\hline $\begin{array}{l}\text { Between Fern Drive } \\
\text { and Elm Drive }\end{array}$ & 1 & 1 & 0 & 0 \\
\hline $\begin{array}{l}\text { Intersection of } \\
\text { Birch Avenue }\end{array}$ & 3 & 2 & 0 & Not Applicable \\
\hline $\begin{array}{l}\text { Between Birch Avenue } \\
\text { and Aspen Avenue }\end{array}$ & 1 & 1 & 0 & 0 \\
\hline $\begin{array}{l}\text { Intersection of } \\
\text { Aspen Avenue }\end{array}$ & 1 & 0 & 0 & Not Applicable \\
\hline $\begin{array}{l}\text { Intersection of } \\
\text { Rhode Island Avenue }\end{array}$ & 1 & 1 & 0 & Not Applicable \\
\hline $\begin{array}{l}\text { Intersection of } \\
\text { S. Industrial Drive }\end{array}$ & 2 & 2 & 0 & Not Applicable \\
\hline $\begin{array}{l}\text { Intersection of } \\
\mathrm{N} \text {. Industrial Drive }\end{array}$ & 1 & 0 & 0 & Not Applicable \\
\hline $\begin{array}{l}\text { Between N. Industrial Drive } \\
\text { and Ohio Avenue }\end{array}$ & 3 & 4 & 0 & 3 \\
\hline $\begin{array}{l}\text { Intersection of } \\
\text { Ohio Avenue }\end{array}$ & 3 & 4 & 0 & Not Applicable \\
\hline $\begin{array}{l}\text { Between "C" Street } \\
\text { and W. Virginia Avenue }\end{array}$ & 1 & 4 & 0 & 0 \\
\hline
\end{tabular}




\begin{tabular}{|l|l|l|l|l||}
\hline \multicolumn{1}{|c|}{ LOCATION } & $\begin{array}{c}\text { NUMBER } \\
\text { OF } \\
\text { ACCIDENTS }\end{array}$ & $\begin{array}{l}\text { NUMBER } \\
\text { INSURED }\end{array}$ & $\begin{array}{l}\text { NUMBER } \\
\text { KILLED }\end{array}$ & $\begin{array}{c}\text { WAB NEARBY } \\
\text { INTERSECTION } \\
\text { AN INFUENCING } \\
\text { FACTOR }\end{array}$ \\
\hline $\begin{array}{l}\text { Between "A" Street } \\
\text { and Blue Springs Avenue }\end{array}$ & 2 & 2 & 0 & 1 \\
\hline $\begin{array}{l}\text { Intersection of } \\
\text { Blue Springs Avenue }\end{array}$ & 3 & 5 & 0 & Not Applicable \\
\hline $\begin{array}{l}\text { Between Rose Avenue } \\
\text { and Cherokee Avenue }\end{array}$ & 1 & 2 & 0 & 1 \\
\hline $\begin{array}{l}\text { Intersection of } \\
\text { Cherokee Avenue }\end{array}$ & 2 & 2 & 0 & Not Applicable \\
\hline $\begin{array}{l}\text { Intersection of } \\
\text { Graves Avenue }\end{array}$ & 6 & 5 & 0 & Not Applicable \\
\hline $\begin{array}{l}\text { Between Graves Avenue } \\
\text { and Central Avenue }\end{array}$ & 1 & 1 & 0 & 0 \\
\hline $\begin{array}{l}\text { Intersection of } \\
\text { French Avenue }\end{array}$ & 1 & 1 & 0 & Not Applicable \\
\hline $\begin{array}{l}\text { Between French Avenue } \\
\text { and May Street }\end{array}$ & 3 & 5 & 0 & 1 \\
\hline $\begin{array}{l}\text { Between Landsdowne Avenue } \\
\text { and Lee Avenue }\end{array}$ & 1 & 0 & 0 & 0 \\
\hline $\begin{array}{l}\text { Intersection of } \\
\text { Wisconsin Avenue }\end{array}$ & 1 & 2 & 0 & Not Applicable \\
\hline & 52 & 66 & 0 & 6 \\
\hline
\end{tabular}

(Source: Bill Linkovich of the Florida Department of Transportation in Deland, Florida) 
TABLE A. 5

EXISTING CONDITION OF ROADB AND REQUIRED REAPAIRS

(0s Route 17-92 is also referred to as Volusia Avenue)

\begin{tabular}{|c|c|c|c|c|c|c|}
\hline STREET NAME & $\begin{array}{l}\text { "COLLECTOR" Or } \\
\text { "LOCAL Or } \\
\text { "COUNTY ROAD" }\end{array}$ & $\begin{array}{c}\text { NEW CONBTRECTION } \\
\text { Or } \\
\text { RESURFACING } \\
\end{array}$ & FROM & TO & & $\cos \mathrm{T}$ \\
\hline Albertus Way & Loca I & New Construction & S. Holly Avenue & s. Oak Ave & $\$$ & 27,450 \\
\hline Banana Avenue, E. & Loca 1 & Resurfacing & US $17-92$ & S. Holly Ave & $\$$ & 12,250 \\
\hline Beau Court & Loca 1 & Resurfacing & W. Wisconsin Avenue & End of $s t$ & $\$$ & 39,200 \\
\hline Blue Springs Avenue, E. & Collector & Resurfacing & US $17-92$ & S. Leavitt Ave & $\$$ & 134,640 \\
\hline Blue Springs Avenue, $W$. & Collector & New Construction & S. Sparkman Avenue & US $17-92$ & $\$$ & 184,800 \\
\hline Brightwood Avenue & Local & Resurfacing & S. Sparkman Avenue & N. Carpenter Ave & $\$$ & 64,680 \\
\hline Brooklyn Avenue & Local & New Construction & S. Carpenter Avenue & S. Park Ave & $\$$ & 36,600 \\
\hline Brooklyn Avenue & Loca I & Resurfacing & S. Park Avenue & US $17-92$ & $\$$ & 29,400 \\
\hline C street, E. & Local & Resurfacing & US $17-92$ & End of $s t$ & $\$$ & 47,040 \\
\hline Carpenter Avenue, N. & Collector & Resurfacing & W. Graves Avenue & W. Wisconsin Ave & $\$$ & 201,960 \\
\hline Carpenter Avenue, S. & Collector & Resurfacing & W. Ohio Avenue & W. Graves Ave & $\$$ & 168,300 \\
\hline Central Avenue, $\boldsymbol{W}$. & Local & Resurfacing & S. Sparkman Avenue & US $17-92$ & $\$$ & 125,440 \\
\hline Cherokee Avenue, E. & Local & Resurfacing & US $17-92$ & S. Holly Ave & $\$$ & 12,250 \\
\hline collins court & Local & Resurfacing & French Avenue, E. & End of st & $\$$ & 12,740 \\
\hline Columbus Avenue & Local & New Construction & End of Street & N. Thorpe Ave & $\$$ & 18,300 \\
\hline Columbus Avenue & Local & Resurfacing & N. Thorpe Avenue & N. Orange Ave & $\$$ & 32,340 \\
\hline Columbus Avenue & Loca 1 & New Construction & N. Orange Avenue & N. Leavitt Ave & $\$$ & 40,260 \\
\hline Daley street & Loca I & Resurfacing & N. Orange Avenue & N. Leavitt Ave & $\$$ & 29,400 \\
\hline Dixson street & Local & Resurfacing & S. Sparkman Avenue & S. Carpenter Ave & $\$$ & 63,700 \\
\hline First street & Loca l & Resurfacing & Plum Drive & End of $s t$ & $\$$ & 44,100 \\
\hline Frederick Avenue & Local & New Construction & W. Blue Springs Avenue & Harrison Ave & $\$$ & 30,500 \\
\hline French Avenue, E. & Local & Resurfacing & US $17-92$ & N. Leavitt Ave & $\$$ & 129,360 \\
\hline French Avenue, $\mathrm{W}$. & County & & S. Sparkman Avenue & US $17-92$ & $\$$ & $168,000 *$ \\
\hline Garden Lane & Loca 1 & New Construction & Tappan Circle & Tappan Circle & $\$$ & 33,550 \\
\hline
\end{tabular}




\begin{tabular}{|c|c|c|c|c|c|c|}
\hline BTREET NAME & $\begin{array}{l}\text { "COLLECTOR" Or } \\
\text { "LOCAL Or } \\
\text { "COUNTY ROAD" }\end{array}$ & $\begin{array}{c}\text { NETI CON8TRUCTION } \\
\text { OI } \\
\text { REBURFACING } \\
\end{array}$ & FROM & To & & COBT \\
\hline Graves Avenue, E. & county & & US $17-92$ & s. Leavitt Ave & $\$$ & 158,400 * \\
\hline Graves Avenue, W. & Collector & New Construction & S. Sparkman Avenue & US $17-92$ & $\$$ & 198,000 \\
\hline Harrison Avenue & Loca 1 & Resurfacing & S. Sparkman Avenue & s. Carpenter Ave & $\$$ & 62,720 \\
\hline Holly Avenue, N. & Local & New Construction & Lee Avenue & End of $s t$ & $\$$ & 21,960 \\
\hline Holly Avenue, $\mathrm{N}$. & Local & Resurfacing & E. Lansdowne Avenue & Lee Ave & $\$$ & 16,170 \\
\hline Holly Avenue, S. & Local & Resurfacing & E. Blue Springs Avenue & E. Graves Ave & $\$$ & 94,080 \\
\hline Howard Avenue & Local & Resurfacing & S. Sparkman Avenue & N. Carpenter Ave & $\$$ & 62,720 \\
\hline Industrial Drive, E. & Collector & Resurfacing & S. Industrial Drive & N. Industrial Dr & $\$$ & 42,840 \\
\hline Industrial Drive, $\mathrm{N}$. & Collector & Resurfacing & US $17-92$ & E. Industrial Dr & $\$$ & 57,120 \\
\hline Industrial Drive, s. & Collector & Resurfacing & US $17-92$ & E. Industrial Dr & $\$$ & 57,120 \\
\hline Jasmine Avenue & Local & New Construction & E. Lansdowne Avenue & E. Wisconsin Ave & $\$$ & 20,130 \\
\hline Lakeview Avenue & Loca 1 & Resurfacing & S. Orange Avenue & s. Leavitt Ave & $\$$ & 29,400 \\
\hline Lansdowne Avenue, E. & Collector & Resurfacing & US $17-92$ & N. Leavitt Ave & $\$$ & 134,640 \\
\hline Lansdowne Avenue, $\mathrm{W}$. & Local & Resurfacing & S. Sparkman Avenue & N. Carpenter Ave & $\$$ & 62,720 \\
\hline Lansdowne Avenue, $w$. & Local & New Construction & N. Carpenter Avenue & End of $s t$ & $\$$ & 61,000 \\
\hline Lantern Lane & Local & Resurfacing & S. Sparkman Avenue & W. Graves Ave & $\$$ & 39,200 \\
\hline Leavitt Avenue, $N$. & Collector & New Construction & E. Graves Avenue & E. Lansdowne Ave & $\$$ & 184,800 \\
\hline Leavitt Avenue, $\mathrm{s}$. & Collector & New Construction & Rhode Island Avenue & E. Graves Ave & $\$$ & 356,400 \\
\hline Lee Avenue & Loca 1 & Resurfacing & US $17-92$ & N. Holly Ave & $\$$ & 12,250 \\
\hline Lee Avenue & Local & New Construction & Sumner Avenue & N. Holly Ave & $\$$ & 15,250 \\
\hline Lynn Avenue & Local & Resurfacing & S. Sparkman Avenue & Second st & $\$$ & 26,460 \\
\hline May street & Loca 1 & Resurfacing & Montclair Terrace & US $17-92$ & $\$$ & 84,770 \\
\hline Montclair Terrace & Local & Resurfacing & W. French Avenue & w. Oakwood Ave & $\$$ & 84,280 \\
\hline Oak Avenue, S. & Loca 1 & Resurfacing & E. Rose Avenue & E. Graves Ave & $\$$ & 34,300 \\
\hline Oakwood Avenue, E. & Local & New Construction & N. Leavitt Avenue & End of $s t$ & $\$$ & 76,520 \\
\hline Oakwood Avenue, w. & Local & Resurfacing & N. Carpenter Ave & End of street & $\$$ & 32,340 \\
\hline
\end{tabular}




\begin{tabular}{|c|c|c|c|c|c|c|}
\hline BTREET MAMB & $\begin{array}{l}\text { "COLLECTOR" or } \\
\text { "LOCAL Or } \\
\text { "COUNTY ROAD" }\end{array}$ & $\begin{array}{c}\text { NEW CONBTRUCTION } \\
\text { Or } \\
\text { REBORPACING }\end{array}$ & FROM & To & & cost \\
\hline Ohio Avenue, E. & Collector & New Construction & US $17-92$ & S. Leavitt Ave & $\$$ & 174,240 \\
\hline Ohio Avenue, $w$. & Local & Resurfacing & S. Sparkman Avenue & Third St & $\$$ & 14,700 \\
\hline Ohio Avenue, $W$. & Collector & Resurfacing & S. Carpenter Avenue & US $17-92$ & $\$$ & 67,320 \\
\hline Orange Avenue, N. & Loca I & Resurfacing & E. University Avenue & E. Lansdowne Ave & $\$$ & 88,200 \\
\hline Orange Avenue, N. & Local & New Construction & Columbus Avenue & E. Wisconsin Ave & $\$$ & 40,260 \\
\hline orange Avenue, $\mathrm{S}$. & Local & Resurfacing & E. Blue Springs Avenue & E. Graves Ave & $\$$ & 98,000 \\
\hline Park Avenue, N. & Loca 1 & New Construction & W. Graves Avenue & พ. French Ave & $\$$ & 76,860 \\
\hline Park Avenue, S. & Local & New Construction & W. Blue Springs Avenue & พ. Virginia Ave & $\$$ & 40,260 \\
\hline Park Drive & Local & Resurfacing & W. Virginia Avenue & W. Blue Springs Ave & $\$$ & 32,340 \\
\hline Patlin Avenue & Local & Resurfacing & S. Sparkman Avenue & S. Carpenter Ave & $\$$ & 64,680 \\
\hline Pine Avenue, $\mathbf{N}$. & Local & Resurfacing & E. French Avenue & E. Pineapple Ave & $\$$ & 29,400 \\
\hline Pine Street & Loca 1 & New Construction & N. Carpenter Avenue & Montclair Terrace & $\$$ & 25,620 \\
\hline Pineapple Avenue, E. & Local & Resurfacing & N. Thorpe Avenue & N. Leavitt Ave & $\$$ & 60,270 \\
\hline Plum Drive & Local & Resurfacing & Second Street & S Park Ave & $\$$ & 67,620 \\
\hline Racine Road & Local & New Construction & พ. Wisconsin Avenue & W. New York Avenue & $\$$ & 30,500 \\
\hline Rhode Island Avenue & Collector & New Construction & US $17-92$ & S. Leavitt Ave & $\$$ & 158,400 \\
\hline Rose Avenue, E. & Local & Resurfacing & US $17-92$ & S. Holly Ave & $\$$ & 12,250 \\
\hline Sandy Pines Drive & Local & Resurfacing & S. Carpenter Avenue & End of st & $\$$ & 31,850 \\
\hline Second street & Local & Resurfacing & พ. Ohio Avenue & w. Blue Springs Ave & $\$$ & 58,800 \\
\hline Sparkman Avenue, $\mathrm{S}$. & County & & W. Ohio Avenue & ผ. Wisconsin Ave & $\$$ & $435,600 \star$ \\
\hline Sumner Avenue & Local & New Construction & E. French Avenue & End of $s t$ & $\$$ & 120,780 \\
\hline Tappan Circle & Local & New Construction & N. Carpenter Avenue & N. Carpenter Ave & $\$$ & 100,650 \\
\hline Taylor Drive & Loca 1 & Resurfacing & E. French Avenue & Sumner Ave & $\$$ & 34,300 \\
\hline Third street & Local & Resurfacing & W. Ohio Avenue & Lynn Ave & $\$$ & 25,970 \\
\hline Thorpe Avenue, S. & Collector & New Construction & Rhode Island Avenue & E. Ohio Ave & $\$$ & 118,800 \\
\hline Thorpe Avenue, $\mathrm{s}$. & Local & Resurfacing & E. Blue Springs Avenue & E. Ohio Ave & $\$$ & 64,680 \\
\hline
\end{tabular}




\begin{tabular}{|c|c|c|c|c|c|}
\hline STREET NAME & $\begin{array}{l}\text { "COLLECTOR" or } \\
\text { "LOCAL Or } \\
\text { "COUNTY ROAD" }\end{array}$ & $\begin{array}{c}\text { NEW COMBTRUCTION } \\
\text { Or } \\
\text { REBURPACING }\end{array}$ & FROM & To & $\cos T$ \\
\hline University Avenue, E. & Local & Resurfacing & US $17-92$ & N. Leavitt Ave & 130,340 \\
\hline University Avenue, $\boldsymbol{W}$. & Local & Resurfacing & US $17-92$ & N. Carpenter Ave & 62,720 \\
\hline Virginia Avenue, w. & Local & New Construction & US $17-92$ & S. Park Ave & 38,430 \\
\hline Virginia Avenue, $\mathbf{W}$. & Local & Resurfacing & S. Park Avenue & S. Carpenter Ave & 32,340 \\
\hline Wisconsin Avenue, $\boldsymbol{~}$. & County & & S. Sparkman Avenue & US $17-92$ & $168,000 *$ \\
\hline & & & & TOTAL: & $\$ 5,286,030 @$ \\
\hline
\end{tabular}

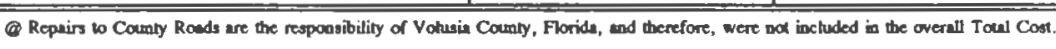

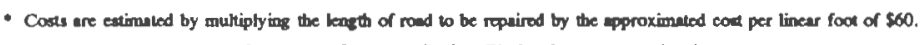

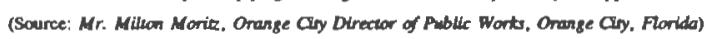


TABLE A. 6

EXIBTING COMMERCIAL BUSINEBSEB BY CATEGORY AND LOCATION

\begin{tabular}{|c|c|c|c|c|c|c|c|c|}
\hline TYPE OF BUBINESB & QOANTITY & $\begin{array}{l}\text { ANBWERED } \\
\text { BOBINEBS } \\
\text { BURVEY } \\
\end{array}$ & $\begin{array}{l}\text { LOCATION } \\
\text { WIBCONBIN TO } \\
\text { FRENCE AVE } \\
\end{array}$ & $\begin{array}{l}\text { IOCATION } \\
\text { PRENCH TO } \\
\text { GRAVE8 AVE } \\
\end{array}$ & $\begin{array}{l}\text { LOCATION } \\
\text { GRAVEB TO BLUE } \\
\text { BPRINGS AVE } \\
\end{array}$ & $\begin{array}{l}\text { LOCATION } \\
\text { BLUE BPRINGB } \\
\text { TO OHIO AVE } \\
\end{array}$ & $\begin{array}{l}\text { LOCATION } \\
\text { OHIO TO RHODE } \\
\text { IBLAND AVE } \\
\end{array}$ & $\begin{array}{l}\text { LOCATION } \\
\text { RHODE IBLAND TO } \\
\text { ENTERPRIBE RD }\end{array}$ \\
\hline Appliance Sales & 2 & 2 & 0 & 0 & 0 & 0 & 0 & 2 \\
\hline Arts, Crafts \& Gifts & 4 & 3 & 0 & 0 & 3 & 0 & 1 & 0 \\
\hline $\begin{array}{l}\text { Automotive Wash } \\
\text { (Carwash) }\end{array}$ & 1 & 0 & 0 & 0 & 0 & 0 & 0 & 1 \\
\hline Automotive Parts & 4 & 1 & 0 & 1 & 0 & 1 & 1 & 1 \\
\hline Automotive Repairs & 8 & 4 & 0 & 0 & 1 & 1 & 3 & 3 \\
\hline $\begin{array}{l}\text { Automotive Sales } \\
\text { (Used \& New) }\end{array}$ & 4 & 3 & 0 & 1 & 1 & 0 & 0 & 2 \\
\hline Bakery & 1 & 1 & 1 & $\underline{0}$ & 0 & 0 & 0 & 0 \\
\hline Bank/Mortgage Co. & 4 & 3 & 0 & 1 & 0 & 1 & 0 & 2 \\
\hline Barber shop & 3 & 2 & 0 & 1 & 1 & 0 & 0 & 1 \\
\hline $\begin{array}{l}\text { Blue-Printing/Photo- } \\
\text { Copying }\end{array}$ & 2 & 2 & 1 & 0 & 0 & 0 & 1 & 0 \\
\hline Businesses Services & 1 & 1 & 0 & 0 & 0 & 1 & 0 & 0 \\
\hline $\begin{array}{l}\text { Certified Public } \\
\text { Accountants }\end{array}$ & 4 & 4 & 1 & 0 & 1 & 1 & 0 & 1 \\
\hline $\begin{array}{l}\text { Clinics } \\
\text { (Miscellaneous) }\end{array}$ & 2 & 0 & 0 & 0 & 0 & 0 & 0 & 2 \\
\hline $\begin{array}{l}\text { Clothing and Footwear } \\
\text { (Retail) }\end{array}$ & 2 & 1 & 0 & 1 & 0 & 0 & 0 & 1 \\
\hline Collectibles & 3 & 1 & 0 & 0 & 1 & 0 & 0 & 2 \\
\hline Communications & 3 & 3 & 0 & 1 & 1 & 0 & 1 & 0 \\
\hline $\begin{array}{l}\text { Computer \& Electronic } \\
\text { Supplies }\end{array}$ & 2 & 2 & 0 & 0 & 0 & 0 & 0 & 2 \\
\hline $\begin{array}{l}\text { Consignment \& Pawn } \\
\text { Shops }\end{array}$ & 4 & 3 & 1 & 1 & 0 & 1 & 0 & 1 \\
\hline
\end{tabular}




\begin{tabular}{|c|c|c|c|c|c|c|c|c|}
\hline TYPE OF BUBINESB & QUANTITY & $\begin{array}{l}\text { ANBWERED } \\
\text { BOBINES8 } \\
\text { SURVEY }\end{array}$ & $\begin{array}{l}\text { LOCATION } \\
\text { WIBCONBIN TO } \\
\text { FRENCH AVB }\end{array}$ & $\begin{array}{l}\text { LOCATION } \\
\text { FRENCH TO } \\
\text { GRAVE8 AVE }\end{array}$ & $\begin{array}{l}\text { LOCATION } \\
\text { GRAVES TO BLUE } \\
\text { BPRINGS AVE }\end{array}$ & $\begin{array}{l}\text { LOCATION } \\
\text { BLUE BPRINGS } \\
\text { TO OHIO AVE }\end{array}$ & $\begin{array}{l}\text { LOCATION } \\
\text { OHIO TO RHODE } \\
\text { IBLAND AVE }\end{array}$ & $\begin{array}{l}\text { LOCATION } \\
\text { RHODE IBLAND TO } \\
\text { ENTERPRIBE RD }\end{array}$ \\
\hline $\begin{array}{l}\text { Construction and } \\
\text { Lumber Supplying co. }\end{array}$ & 4 & 2 & 0 & 0 & 1 & 0 & 1 & 2 \\
\hline Convenience Stores & 3 & 1 & 0 & 1 & 0 & 1 & 0 & 1 \\
\hline $\begin{array}{l}\text { Dance Studios \& } \\
\text { Musical Supplies }\end{array}$ & 3 & 2 & 0 & 0 & 0 & 1 & 2 & 0 \\
\hline $\begin{array}{l}\text { Doctors (M.D. , Dent. } \\
\& \text { Chiropractor) }\end{array}$ & 7 & 4 & 2 & 0 & 1 & 0 & 4 & 0 \\
\hline $\begin{array}{l}\text { Dry cleaners \& } \\
\text { Laundromats }\end{array}$ & 2 & 1 & 0 & 0 & 0 & 0 & 0 & 2 \\
\hline $\begin{array}{l}\text { Engineering \& } \\
\text { Surveying }\end{array}$ & 3 & 2 & 0 & 0 & 0 & 1 & 0 & 2 \\
\hline Environmental Svcs & 1 & 1 & 0 & 0 & 0 & 1 & 0 & 0 \\
\hline Exterminators & 1 & 1 & 1 & 0 & 0 & 0 & 0 & 0 \\
\hline Florist & 1 & 0 & 0 & 1 & 0 & 0 & 0 & 0 \\
\hline Funeral Home & 1 & 1 & 0 & 0 & 1 & 0 & 0 & 0 \\
\hline $\begin{array}{l}\text { Furniture/Antiques } \\
\text { Including-Second Hand }\end{array}$ & 10 & 6 & 4 & 1 & 0 & 0 & 2 & 3 \\
\hline Garden Products & 1 & 1 & 1 & 0 & 0 & 0 & 0 & 0 \\
\hline Gas station & 5 & 4 & 0 & 2 & 0 & 1 & 0 & 2 \\
\hline $\begin{array}{l}\text { Grocery \& Fruit } \\
\text { Stores }\end{array}$ & 2 & 0 & 1 & 0 & 0 & 0 & 0 & 1 \\
\hline Hair \& Nail Salons & 8 & 5 & 2 & 1 & 1 & 0 & 3 & 1 \\
\hline Hardware & 4 & 3 & 3 & 0 & 0 & 0 & 1 & 0 \\
\hline $\begin{array}{l}\text { Hauling Equipment } \\
\text { (Self) }\end{array}$ & 1 & 0 & 0 & 0 & 0 & 1 & 0 & 0 \\
\hline Hearing Aid Ctrs & 2 & 1 & 1 & 0 & 0 & 0 & 1 & 0 \\
\hline Home Maintenance Svc & 1 & 0 & 0 & 0 & 0 & 0 & 0 & 1 \\
\hline
\end{tabular}




\begin{tabular}{|c|c|c|c|c|c|c|c|c|}
\hline TYPE OF BUSINESB & QUANTITX & $\begin{array}{l}\text { ANBWERED } \\
\text { BUSINESB } \\
\text { BURVEX } \\
\end{array}$ & $\begin{array}{l}\text { LOCATION } \\
\text { WIBCONBIN TO } \\
\text { FRENCH AVE } \\
\end{array}$ & $\begin{array}{l}\text { LOCATION } \\
\text { FRENCH TO } \\
\text { GRAVEB AVE } \\
\end{array}$ & $\begin{array}{l}\text { LOCATION } \\
\text { GRAVEB TO BLUE } \\
\text { BPRINGS AVE } \\
\end{array}$ & $\begin{array}{l}\text { LOCATION } \\
\text { BLUE BPRINGB } \\
\text { TO OHIO AVE } \\
\end{array}$ & $\begin{array}{l}\text { LOCATION } \\
\text { OHIO TO RHODE } \\
\text { IBLAND AVE } \\
\end{array}$ & $\begin{array}{l}\text { LOCATION } \\
\text { RHODE IBLAND TO } \\
\text { ENTERPRIBE RD } \\
\end{array}$ \\
\hline Insurance & 8 & 6 & 0 & 1 & 1 & 2 & 2 & 2 \\
\hline Investment Counseling & 4 & 2 & 0 & 0 & 0 & 2 & 0 & 2 \\
\hline Lawyer/Attorney & 4 & 1 & 0 & 1 & 0 & 1 & 0 & 2 \\
\hline $\begin{array}{l}\text { Lounge/Bar } \\
\text { Liquor Store }\end{array}$ & 2 & 1 & 1 & 0 & 0 & 0 & 0 & 1 \\
\hline Motel & 3 & 2 & 0 & 0 & 1 & 1 & 1 & 0 \\
\hline $\begin{array}{l}\text { Motorcycle Sales \& } \\
\text { Repairs }\end{array}$ & 1 & 0 & 0 & 0 & 0 & 0 & 0 & 1 \\
\hline Realtors \& Titlists & 7 & 5 & 0 & 0 & 3 & 1 & 1 & 2 \\
\hline Recreational Facility & 1 & 1 & 0 & 0 & 0 & 0 & 0 & 1 \\
\hline $\begin{array}{l}\text { Religious Supplies \& } \\
\text { Mail Order }\end{array}$ & 2 & 2 & 0 & 0 & 0 & 0 & 0 & 2 \\
\hline $\begin{array}{l}\text { Restaurant \& Deli } \\
\text { (Dine-In) }\end{array}$ & 6 & 4 & 1 & 0 & 1 & 0 & 1 & 3 \\
\hline $\begin{array}{l}\text { Restaurant (Fast- } \\
\text { Food) }\end{array}$ & 2 & 0 & 1 & 0 & 0 & 0 & 0 & 1 \\
\hline $\begin{array}{l}\text { Retail - } \\
\text { Miscellaneous }\end{array}$ & 1 & 1 & 0 & 0 & 0 & 0 & 1 & 0 \\
\hline Sporting Supplies & 1 & 1 & 0 & 0 & 1 & 0 & 0 & 0 \\
\hline Travel Agencies & 2 & 1 & 0 & 0 & 0 & 0 & 1 & 1 \\
\hline $\begin{array}{l}\text { Veterinarians \& Pet } \\
\text { Care (Feed Stores) }\end{array}$ & 4 & 1 & 1 & 0 & 0 & 0 & 2 & 1 \\
\hline Wholesale Goods & 1 & 0 & 0 & 1 & 0 & 0 & 0 & 0 \\
\hline TOTAL: & 179 & $105 *$ & 24 & 20 & 21 & 22 & 33 & 59 \\
\hline
\end{tabular}

(Source: Survey analysis conducted by author during the period of February 21 - March 2, 1994) 
TABLE A.7 - BIGN ANALYBIB

BAKPLING OF BUBINEBBEB WITHIN THE PROJECT AREA

\begin{tabular}{|c|c|c|c|c|c|c|c|c|c|c|c|c|}
\hline $\begin{array}{l}\text { Name of } \\
\text { Business }\end{array}$ & & $\begin{array}{l}\text { Bus } \\
\text { Add }\end{array}$ & $\begin{array}{l}\text { iness } \\
\text { dress }\end{array}$ & $\begin{array}{l}\text { Type } \\
\text { of } \\
\text { Devlp }\end{array}$ & $\begin{array}{l}\text { Type } \\
\text { of } \\
\text { sign }\end{array}$ & $\begin{array}{l}\text { Total } \\
\text { Sign } \\
\text { Hgth }\end{array}$ & $\begin{array}{l}\text { Sign } \\
\text { Area } \\
\text { Hgth }\end{array}$ & $\begin{array}{l}\text { Sign } \\
\text { Area } \\
\text { wdth }\end{array}$ & $\begin{array}{l}\text { Sign } \\
\text { Area } \\
\text { SqFt }\end{array}$ & $\begin{array}{l}\text { Wall } \\
\text { Sign } \\
\text { SqFt }\end{array}$ & $\begin{array}{l}\text { Frnt } \\
\text { Set } \\
\text { Back }\end{array}$ & $\begin{array}{l}\text { Side } \\
\text { Set } \\
\text { Back } \\
---\end{array}$ \\
\hline Hidden Garden & 1111 & $N$ & Volusia & Sgl & Mt & 12 & 10 & 6 & 60 & 0 & OK & OK \\
\hline \multirow[t]{2}{*}{ Pier Sixteen } & 1081 & $\mathrm{~N}$ & Volusia & sgl & $\mathrm{Pl}$ & 20 & 10 & 6 & 60 & 0 & 5 & OK \\
\hline & & & & & $w / c c$ & & 6 & 4 & 24 & & & \\
\hline \multirow[t]{3}{*}{ Volusia Rental } & 1065 & $5 \mathrm{~N}$ & Volusia & Sgl & Pl & 18 & 4 & 13 & 52 & 240 & 1 & OK \\
\hline & & & & & & & 3 & 6 & 18 & & & \\
\hline & & & & & $w / c c$ & & 4 & 9 & 36 & & & \\
\hline 951 Building & 951 & $\mathbf{N}$ & Volusia & M1t & P1 & 18 & 10 & 8 & 80 & 0 & 5 & OK \\
\hline Miracle Ear & 879 & $\mathbf{N}$ & Volusia & Sgl & Mt & 15 & 15 & 10 & 150 & 30 & 5 & OK \\
\hline \multirow[t]{2}{*}{ Mighty Mall } & 747 & $\mathbf{N}$ & Volusia & sgl & Pl & 15 & 8 & 4 & 32 & 96 & 5 & OK \\
\hline & & & & & $w / c c$ & & 4 & 8 & 32 & & & \\
\hline Curiosity Cor & 746 & $\mathbf{N}$ & Volusia & $\mathrm{Sgl}$ & & & 0 & 0 & 0 & 120 & / & l \\
\hline \multirow[t]{2}{*}{ Discount Whse } & 745 & $\mathrm{~N}$ & Volusia & Sgl & Pl & 17 & 5 & 8 & 40 & 32 & 5 & OK \\
\hline & & & & & $\mathrm{CC}$ & 7 & 3 & 8 & 24 & & 8 & OK \\
\hline \multirow{2}{*}{$\begin{array}{l}\text { Dr. Duncil } \\
\text { Country store }\end{array}$} & 742 & $\mathbf{N}$ & Volusia & Sgl & Mt & 5 & 3 & 8 & 24 & 0 & 6 & OK \\
\hline & 741 & $\mathbf{N}$ & Volusia & $\mathrm{sgl}$ & & & 0 & 0 & 0 & 24 & / & / \\
\hline \multirow{6}{*}{$\begin{array}{l}\text { Blue Sprgs Anml } \\
\text { Ed Senez } \\
\text { Daley's Bar } \\
\text { Boughton Ciniro }\end{array}$} & & $\mathbf{N}$ & volusia & $\operatorname{sg} 1$ & PI & 15 & 8 & 7 & 56 & 0 & 0 & OK \\
\hline & 720 & $\mathbf{N}$ & Volusia & $\mathrm{Sgl}$ & Pl & 12 & 7 & 10 & 70 & 0 & 0 & OK \\
\hline & 641 & $\mathbf{N}$ & Volusia & $\mathrm{sgl}$ & $\mathrm{Pl}$ & 16 & 7 & 14 & 98 & 0 & 2 & OK \\
\hline & 640 & $\mathbf{N}$ & Volusia & Mit & $\mathrm{Pl}$ & 16 & 4 & 8 & 32 & 0 & 10 & OK \\
\hline & & & & & & & 2 & 8 & 16 & & & \\
\hline & & & & & $\mathrm{CC}$ & 7 & 4 & 8 & 32 & & 4 & OK \\
\hline \multirow[t]{2}{*}{ Anderson"g Hdwr } & 595 & $\mathbf{N}$ & Volusia & Sgl & Pl & 18 & 8 & 6 & 48 & 0 & 8 & OK \\
\hline & & & & & Mt & 18 & 10 & 8 & 80 & 0 & 8 & OK \\
\hline \multirow{4}{*}{$\begin{array}{l}\text { Kenny ' g Grocery } \\
\text { Napa Auto Parts } \\
\text { Fina Serv Statn }\end{array}$} & 500 & $\mathbf{N}$ & Volusia & Sgl & $\mathbf{P l}$ & 17 & 8 & 6 & 48 & 150 & $0 / 10$ & OK \\
\hline & 501 & $\mathbf{N}$ & Volusia & Sgl & Pl & 20 & 7 & 4 & 28 & 98 & 7 & OK \\
\hline & 495 & $\mathbf{N}$ & Volusia & sgl & Pl & 19 & 7 & 5 & 35 & 40 & 2 & OK \\
\hline & & & & & & & 4 & 5 & 20 & & & \\
\hline \multirow{4}{*}{$\begin{array}{l}\text { Citgo Serv stat } \\
400 \text { Building } \\
\text { Citrus Carpet }\end{array}$} & 440 & $\mathbf{N}$ & Volusia & sgl & Pl & 26 & 18 & 7 & 126 & 0 & $2 / 20$ & OK \\
\hline & 400 & $\mathbf{N}$ & Volusia & & Pl & 17 & 6 & 6 & 36 & 0 & 0 & $\mathrm{OK}$ \\
\hline & 347 & $\mathbf{N}$ & Volusia & Sgl & PI & 16 & 2 & 7 & 14 & 30 & 3 & OK \\
\hline & & & & & P1 & 7 & 4 & 6 & 24 & & 9 & OK \\
\hline \multirow[t]{2}{*}{ orng cty Florst } & 336 & $\mathbf{N}$ & Volusia & sgl & Pl & 15 & 3 & 10 & 30 & 0 & 1 & OK \\
\hline & & & & & Rf & & 2 & 15 & 30 & & & \\
\hline \multirow{6}{*}{$\begin{array}{l}\text { Hendersn's Vac } \\
\text { Marshall } \\
\text { Shoe Repair } \\
\text { Atchley Applnce }\end{array}$} & 308 & $\mathbf{N}$ & Volusia & Sgl & Pl & 14 & 10 & 4 & 40 & 32 & 0 & OK \\
\hline & 301 & $\mathbf{N}$ & Volusia & sgl & Mt & 6 & 3 & 4 & 12 & 0 & 3 & OK \\
\hline & 239 & $\mathbf{N}$ & Volusia & sgl & & & 0 & 0 & 0 & 64 & / & / \\
\hline & 236 & $\mathbf{N}$ & Volusia & sgl & Pl & 26 & 8 & 14 & 112 & 0 & $0 / 15$ & OK \\
\hline & & & & & & & 4 & 7 & 28 & & & \\
\hline & & & & & $\mathrm{Hg}$ & & 3 & 6 & 18 & & & \\
\hline United Tele & 219 & $\mathbf{N}$ & Volusia & Sgl & & & 0 & 0 & 0 & 15 & / & / \\
\hline \multirow{3}{*}{$\begin{array}{l}\text { APC Auto Alms } \\
\text { Org Cty secd Hd } \\
\text { Jiffy }\end{array}$} & 214 & $\mathbf{N}$ & Volusia & $\mathrm{Sgl}$ & & & 0 & 0 & 0 & 54 & / & / \\
\hline & 200 & $\mathbf{N}$ & Volusia & sgl & & & 0 & 0 & 0 & 56 & / & / \\
\hline & 150 & $\mathbf{N}$ & Volusia & Mlt & Pl & 14 & 6 & 6 & 36 & 16 & 0 & OK \\
\hline \multirow[t]{2}{*}{ Regency Motors } & 103 & $\mathbf{N}$ & Volusia & $\mathrm{sgl}$ & $\mathrm{Pl}$ & 15 & 8 & 5 & 36 & 75 & 2 & OK \\
\hline & & & & & $\mathrm{Pl}$ & 16 & 5 & 10 & 50 & & 0 & OK \\
\hline & 125 & $s$ & Volusia & $\mathrm{sgl}$ & & & 0 & 0 & 0 & 30 & $/$ & / \\
\hline \multirow[t]{4}{*}{ Stolls Auto Sal } & 149 & $s$ & Volusia & sgl & Pl & 20 & 6 & 10 & 60 & 0 & 2 & OK \\
\hline & & & & & & & 4 & 3 & 12 & & & \\
\hline & & & & & $\omega / c c$ & & 2 & 5 & 10 & & & \\
\hline & & & & & Ag & & 2 & 5 & 10 & 0 & / & I \\
\hline \multirow{2}{*}{$\begin{array}{l}\text { Summerhill F/H } \\
\text { Webster Medical }\end{array}$} & 163 & $s$ & Volusia & sgl & $\mathrm{Pl}$ & 9 & 3 & 10 & 30 & 24 & 1 & $\mathrm{OK}$ \\
\hline & 211 & $s$ & Volusia & Mit & $\mathrm{Pl}$ & 10 & 5 & 7 & 35 & 0 & 0 & OK \\
\hline
\end{tabular}




\begin{tabular}{|c|c|c|c|c|c|c|c|c|c|c|c|c|}
\hline $\begin{array}{l}\text { Name of } \\
\text { Business }\end{array}$ & \multicolumn{3}{|c|}{$\begin{array}{l}\text { Business } \\
\text { Address }\end{array}$} & $\begin{array}{l}\text { Type } \\
\text { of } \\
\text { Devlp }\end{array}$ & $\begin{array}{l}\text { Type } \\
\text { of } \\
\text { Sign }\end{array}$ & $\begin{array}{l}\text { Total } \\
\text { Sign } \\
\text { Hgth }\end{array}$ & $\begin{array}{l}\text { Sign } \\
\text { Area } \\
\text { Hgth }\end{array}$ & $\begin{array}{l}\text { Sign } \\
\text { Area } \\
\text { Wdth }\end{array}$ & $\begin{array}{l}\text { Sign } \\
\text { Area } \\
\text { SqFt }\end{array}$ & $\begin{array}{l}\text { Wall } \\
\text { Sign } \\
\text { SqFt }\end{array}$ & $\begin{array}{l}\text { Frnt } \\
\text { Set } \\
\text { Back }\end{array}$ & $\begin{array}{l}\text { Side } \\
\text { Set } \\
\text { Back } \\
---\end{array}$ \\
\hline Mike's Tobacco & 226 & $\mathbf{s}$ & Volusia & Mlt & $\mathrm{Pl}$ & 18 & 13 & 4 & 52 & 55 & $0 / 0$ & OK \\
\hline H Warner Atty & 227 & $\mathbf{s}$ & Volusia & Mlt & $\mathrm{Pl}$ & 6 & 2 & 4 & 8 & 0 & 3 & OK \\
\hline Insurnce World & 234 & $\mathbf{s}$ & Volusia & sgl & P1 & 16 & 5 & 10 & 50 & 12 & 1 & OK \\
\hline \multirow[t]{2}{*}{ Country Cottage } & 239 & $\mathbf{s}$ & Volusia & sgl & Pl & 12 & 4 & 8 & 32 & 0 & 1 & OK \\
\hline & & & & & Port & 6 & 4 & 8 & 32 & 0 & OK & OK \\
\hline \multirow{3}{*}{$\begin{array}{l}\text { Dotties Dollg } \\
\text { (DeYarman Sqre) }\end{array}$} & 257 & $\mathbf{s}$ & Volusia & sgl & Pl & 6 & 4 & 5 & 20 & 0 & 1 & OK \\
\hline & 300 & $s$ & Volusia & Mit & Mt & 25 & 4 & 20 & 80 & 0 & OK & OK \\
\hline & & & & & $\mathrm{CC}$ & 7 & 4 & 8 & 32 & 0 & OK & OK \\
\hline \multirow[t]{2}{*}{ Stavros } & 413 & $\mathbf{s}$ & Volusia & Sgl & Pl & 20 & 10 & 8 & 80 & 24 & 1 & OK \\
\hline & & & & & $\mathrm{CC}$ & 6 & 3 & 5 & 15 & 0 & 1 & OK \\
\hline Blue Sprgs Plz & 425 & $\mathbf{s}$ & Volusia & MIt & Mt & 14 & 10 & 5 & 50 & & 1 & OK \\
\hline \multirow[t]{2}{*}{ Comfort Inn } & 445 & $\mathbf{s}$ & Volusia & Mlt & Mt & 18 & 4 & 12 & 48 & 0 & 0 & OK \\
\hline & & & & & $w / c c$ & & 3 & 8 & 24 & & & \\
\hline Caldwell Banker & & $\mathbf{s}$ & volusia & Mlt & Mt & 15 & 8 & 5 & 40 & & 7 & OK \\
\hline \multirow{3}{*}{ Martin Serv sta } & 515 & $\mathbf{s}$ & volusia & Sgl & $\mathrm{Pl}$ & 12 & 10 & 4 & 40 & 0 & 1 & oK \\
\hline & & & & & $\mathrm{Pl}$ & 23 & 16 & 8 & 128 & 0 & 5 & OK \\
\hline & & & & & $\omega / c c$ & & 4 & 8 & 32 & & & \\
\hline Gateway Bedding & 600 & $\mathbf{s}$ & volusia & Sgl & $\mathrm{Pl}$ & 14 & 4 & 8 & 32 & 0 & 2 & OK \\
\hline \multirow[t]{3}{*}{ Brake Shop } & 609 & $\mathbf{s}$ & Volusia & SgI & $\mathrm{PI}$ & 13 & 5 & 8 & 40 & 0 & 1 & OK \\
\hline & & & & & $\omega / c c$ & & 4 & 8 & 32 & & & \\
\hline & & & & & Rf & & 4 & 6 & 24 & 0 & / & / \\
\hline Org $\mathbf{C y}$ Auto Pts & 620 & $s$ & Volusia & $\mathbf{S g I}$ & $\mathrm{Pl}$ & 15 & 6 & 5 & 30 & 0 & 0 & oK \\
\hline & & & & & $\mathrm{Ag}$ & & 3 & 40 & 120 & 0 & / & / \\
\hline U-Haul & 630 & $\mathbf{s}$ & Volusia & Mlt & PI & 26 & 7 & 10 & 70 & 86 & 1 & OK \\
\hline & & & & & & & 8 & 8 & 64 & & & \\
\hline & & & & & & & 4 & 8 & 32 & & & \\
\hline & & & & & PI & 14 & 3 & 6 & 18 & 0 & OK & OK \\
\hline Sixma'g & 651 & $\mathbf{s}$ & Volusia & Sgl & Mt & 7 & 3 & 8 & 24 & 60 & 4 & OK \\
\hline McRoberts Tire & 680 & $\mathbf{s}$ & Volusia & sgl & PI & 22 & 4 & 24 & 96 & 256 & 0 & OK \\
\hline & & & & & & & 4 & 18 & 72 & & & \\
\hline Org Cty Motel & 725 & $\mathbf{s}$ & volusia & MIt & Pl & 16 & 6 & 10 & 55 & 48 & 0 & OK \\
\hline & & & & & & & 3 & 2 & 6 & & & \\
\hline Org Cty Ex Ctr & & s & Volusia & Mlt & PI & 18 & 4 & 10 & 40 & 0 & 0 & OK \\
\hline & & & & & & & 5 & 8 & 40 & & & \\
\hline & & & & & $\mathrm{Pl}$ & 13 & 4 & 4 & 16 & 0 & OK & 0 \\
\hline Omega & 830 & $\mathbf{s}$ & Volusia & Sgl & $\mathrm{Pl}$ & 20 & 5 & 15 & 75 & 80 & 0 & OK \\
\hline & & & & & & & 4 & 7 & 28 & & & \\
\hline NCNB Bank & 850 & $\mathrm{~s}$ & Volusia & Sgl & $\mathrm{Pl}$ & 17 & 6 & 10 & 60 & 30 & 0 & OK \\
\hline Cumberlnd Farms & 893 & $\mathbf{s}$ & Volusia & Mit & Pl & 12 & 6 & 4 & 24 & 98 & 1 & 0 \\
\hline & & & & & Pl & 25 & 6 & 8 & 48 & 0 & OK & 5 \\
\hline & & & & & & & 3 & 6 & 18 & & & \\
\hline Fountain View & 910 & s & Volusia & Mlt & Pl & 15 & 5 & 7 & 35 & 300 & 0 & OK \\
\hline & & & & & Mt & 12 & 5 & 7 & 35 & 0 & 5 & OK \\
\hline Pioneer & 924 & $\mathbf{s}$ & Volusia & Sgl & $\mathrm{Pl}$ & 30 & 12 & 10 & 120 & 248 & 0 & OK \\
\hline Midas & 928 & $\mathbf{s}$ & Volusia & sgl & Pl & 30 & 15 & 8 & 120 & 250 & 3 & 12 \\
\hline & & & & & $w / c c$ & & 4 & 8 & 32 & & & \\
\hline Hasit House & 1035 & $\mathbf{s}$ & Volusia & Sgl & $\mathrm{CC}$ & & 5 & 8 & 40 & 226 & 0 & OK \\
\hline Quincy's Stk Hs & 1070 & $\mathrm{~s}$ & Volusia & Sgl & Pl & 35 & 10 & 15 & 150 & 64 & OK & OK \\
\hline & & & & & & & 2 & 8 & 16 & & & \\
\hline & & & & & $w / c c$ & & 4 & 8 & 32 & & & \\
\hline
\end{tabular}




\begin{tabular}{|c|c|c|c|c|c|c|c|c|c|c|c|c|}
\hline $\begin{array}{l}\text { Name of } \\
\text { Business }\end{array}$ & & $\begin{array}{l}\text { usi } \\
\text { Add }\end{array}$ & $\begin{array}{l}\text { iness } \\
\text { ress }\end{array}$ & $\begin{array}{c}\text { Type } \\
\text { of } \\
\text { Devlp }\end{array}$ & $\begin{array}{l}\text { Type } \\
\text { of } \\
\text { sign }\end{array}$ & $\begin{array}{l}\text { Total } \\
\text { Sign } \\
\text { Hgth }\end{array}$ & $\begin{array}{l}\text { Sign } \\
\text { Area } \\
\text { Hgth }\end{array}$ & $\begin{array}{l}\text { Sign } \\
\text { Area } \\
\text { Wdth }\end{array}$ & $\begin{array}{l}\text { Sign } \\
\text { Area } \\
\text { SqFt }\end{array}$ & $\begin{array}{l}\text { Wall } \\
\text { Sign } \\
\text { SqFt }\end{array}$ & $\begin{array}{l}\text { Frnt } \\
\text { Set } \\
\text { Back }\end{array}$ & $\begin{array}{l}\text { side } \\
\text { Set } \\
\text { Back }\end{array}$ \\
\hline \multirow[t]{7}{*}{ Mosca Plaza } & & $\mathbf{s}$ & Volusia & Mlt & PI & 13 & 4 & 6 & 24 & 168 & 1 & 10 \\
\hline & & & & & Pl & 18 & 3 & 6 & 18 & 0 & 6 & 0 \\
\hline & & & & & & & 3 & 4 & 12 & & & \\
\hline & & & & & & & 3 & 4 & 12 & & & \\
\hline & & & & & & & 3 & 6 & 18 & & & \\
\hline & & & & & $w / c c$ & & 3 & 6 & 18 & & & \\
\hline & & & & & $\mathrm{Hg}$ & & 3 & 5 & 15 & 0 & 1 & 1 \\
\hline \multirow[t]{4}{*}{3 Season's Pl } & & $\mathbf{s}$ & Volusia & Mlt & P1 & 8 & 2 & 3 & 6 & 0 & OK & OK \\
\hline & & & & & Pl & 20 & 10 & 13 & 130 & 0 & 0 & OK \\
\hline & & & & & & & 1 & 3 & 3 & & & \\
\hline & & & & & Pl & 9 & 4 & 8 & 32 & 0 & OK & 3 \\
\hline og Cty Ani clnc & 1220 & $\mathbf{s}$ & Volusia & Sol & Mt & 6 & 4 & 8 & 32 & 0 & 3 & OK \\
\hline \multirow{9}{*}{$\begin{array}{l}\text { Dr Wella } \\
\text { Window Shoppe }\end{array}$} & 1251 & $\mathbf{s}$ & Volusia & Mit & Pl & 17 & 8 & 4 & 32 & 124 & 0 & OK \\
\hline & 1280 & $s$ & Volusia & Mlt & Pl & 20 & 4 & 8 & 32 & 192 & OK & OK \\
\hline & & & & & & & 4 & 4 & 16 & & & \\
\hline & & & & & & & 2 & 3 & 6 & & & \\
\hline & & & & & $w / c c$ & & 4 & 8 & 32 & & & \\
\hline & & & & & Pl & 20 & 4 & 6 & 24 & 0 & 3 & OK \\
\hline & & & & & & & 8 & 10 & 80 & & & \\
\hline & & & & & $\mathrm{Hg}$ & & 2 & 13 & 26 & 0 & / & / \\
\hline & & & & & Port & 2 & 1 & 2 & 2 & 0 & OK & OK \\
\hline \multirow[t]{4}{*}{ Blue Spg Ctr } & & $\mathbf{s}$ & Volusia & Mlt & Pl & 35 & 15 & 10 & 150 & 0 & 4 & OK \\
\hline & & & & & & & 5 & 4 & 20 & & & \\
\hline & & & & & $\omega / c c$ & & 8 & 10 & 80 & & & \\
\hline & & & & & Pl & 4 & 4 & 2 & 8 & 0 & OK & OK \\
\hline \multirow[t]{4}{*}{ Antques \& Thngs } & 1427 & $\mathbf{s}$ & Volusia & Mlt & PI & 7 & 4 & 8 & 32 & 8 & 2 & OK \\
\hline & & & & & Pl & 16 & 4 & 12 & 48 & 0 & OK & OK \\
\hline & & & & & & & 2 & 5 & 10 & & & \\
\hline & & & & & $\omega / c c$ & & 4 & 8 & 32 & & & \\
\hline \multirow[t]{2}{*}{ Eng Complex } & 1495 & $\mathbf{s}$ & Volusia & Mlt & Mt & 15 & 6 & 6 & 36 & 0 & OK & OK \\
\hline & & & & & & & 3 & 10 & 30 & & & \\
\hline Kitchens Rest & 1501 & $\mathbf{s}$ & Volusia & Sgl & Pl & 16 & 6 & 9 & 54 & 0 & OK & OK \\
\hline \multirow[t]{3}{*}{ Carl \& Bob's } & 1511 & $\mathbf{s}$ & Volusia & sgl & Pl & 16 & 4 & 8 & 32 & 36 & OK & OK \\
\hline & & & & & & & 2 & 4 & 8 & & & \\
\hline & & & & & $w / c c$ & & 4 & 8 & 32 & & & \\
\hline \multirow[t]{4}{*}{ Jet Mart } & & $\mathbf{s}$ & Volusia & Sgl & Pl & 24 & 5 & 9 & 45 & 192 & OK & 0 \\
\hline & & & & & & & 5 & 3 & 15 & & & \\
\hline & & & & & & & 5 & 3 & 15 & & & \\
\hline & & & & & $w / c c$ & & 9 & 9 & 81 & & & \\
\hline \multirow[t]{4}{*}{ Big T Tire } & 1695 & $\mathbf{S}$ & Volusia & Sgl & Pl & 30 & 5 & 3 & 15 & 238 & OK & OK \\
\hline & & & & & & & 4 & 16 & 64 & & & \\
\hline & & & & & & & 5 & 12 & 60 & & & \\
\hline & & & & & & & 3 & 10 & 30 & & & \\
\hline Physical Place & 1720 & $\mathbf{s}$ & Volusia & sgl & $\mathrm{CC}$ & 8 & 4 & 8 & 32 & 72 & 2 & OK \\
\hline \multirow[t]{2}{*}{4 Townes Ex Ctr } & & $s$ & Volusia & Mit & P1 & 24 & 6 & 15 & 90 & 0 & 2 & OK \\
\hline & & & & & & & 8 & 4 & 32 & & & \\
\hline \multirow[t]{3}{*}{ Pooser PK Pl } & 1810 & $\mathbf{s}$ & Volusia & Mlt & Pl & 6 & 3 & 3 & 9 & 127 & OK & OK \\
\hline & & & & & Pl & 23 & 5 & 10 & 50 & 0 & OK & OK \\
\hline & & & & & & & 10 & 10 & 100 & & & \\
\hline
\end{tabular}




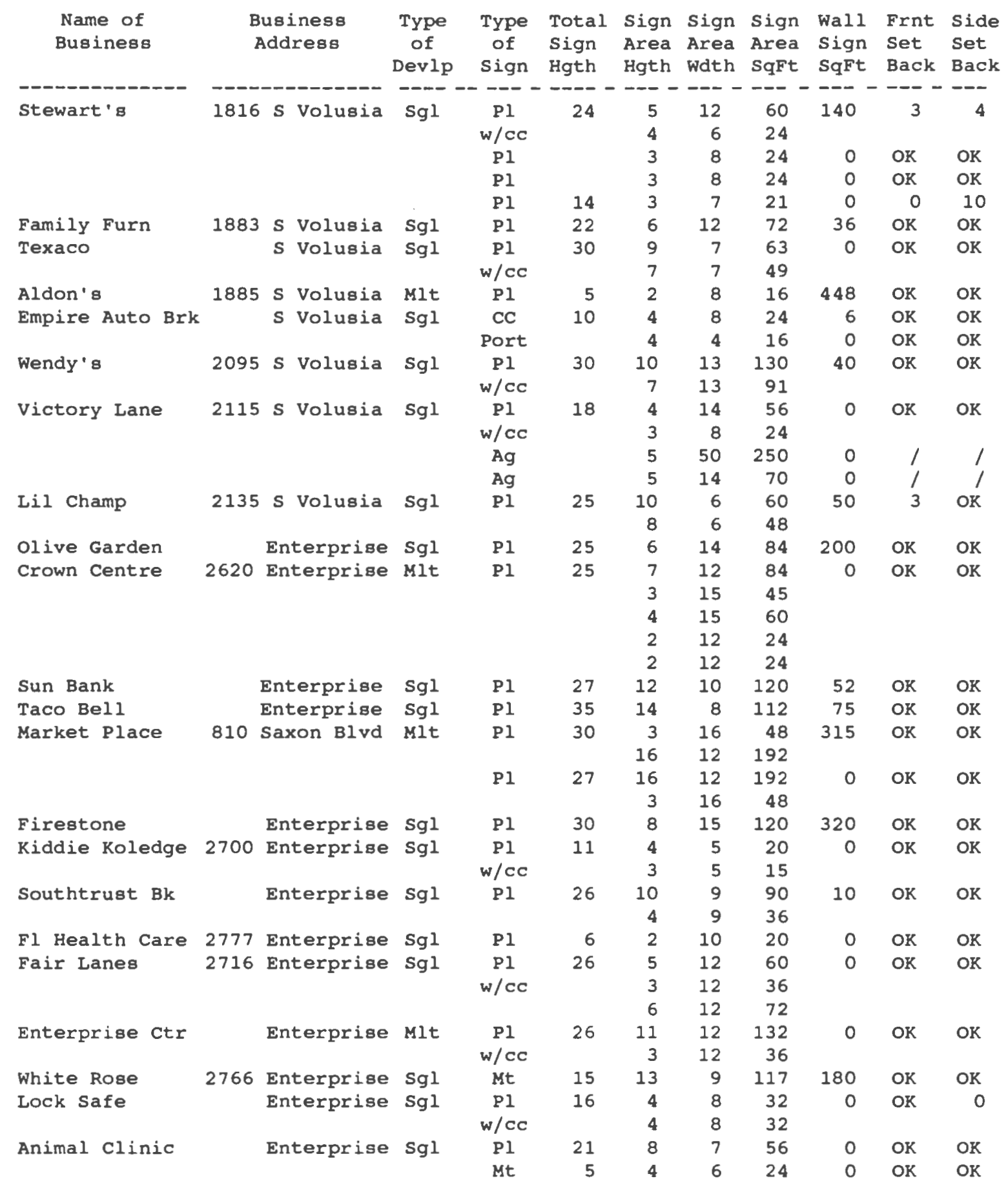




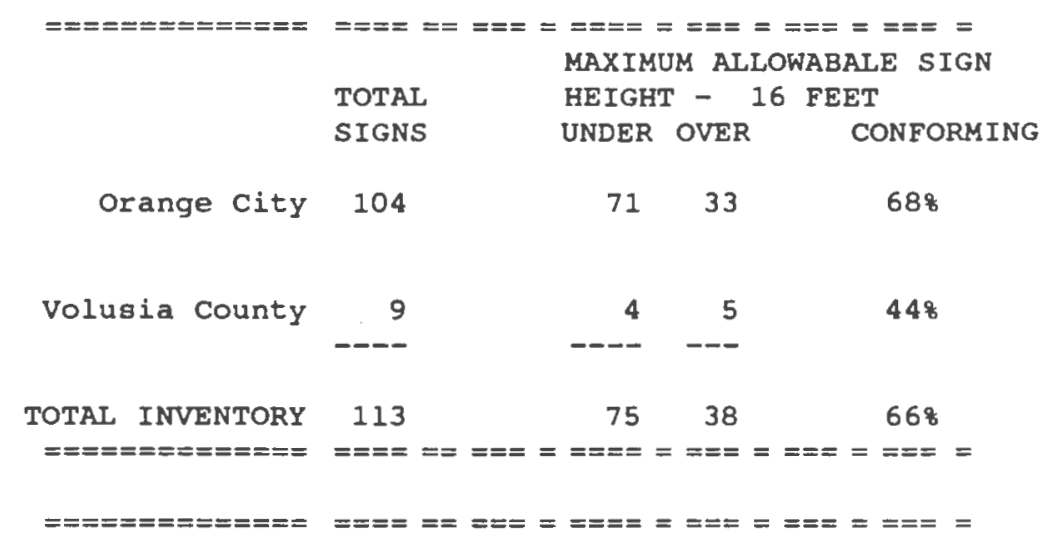

Source: Existing sign analysis conducted by the author and Mr. James Kerr, Orange City Planning and zoning Coordinator, between January and April 1991. 
TABLE A.8

\section{R E S I D E N T S U R V E Y}

Preliminary Information:

$\begin{array}{ll}\text { Sex: } & M \\ \text { Age: } & \\ & 0-10 \\ 11-20 \\ 21-30 \\ 31-40 \\ 41-50 \\ 51-60 \\ 61+\text { Above. }\end{array}$

1. Do you feel safe when driving on Us Route 17-92:

Yes No Not Sure

If "NO", why not -

2. Do you feel that automobile speeds are safe:

Yes No Not Sure

3. Do you feel that the area is pedestrian safe:

$$
\text { Yes No Not Sure }
$$

4. Do you feel that there are enough pedestrian amenities:

$$
\text { If "NO", do you have any suggestions - }
$$

5. Do you think the corridor is pleasing to look at:

$$
\text { Yes No Not Sure }
$$

6. Is the present signage visually pleasing:

$$
\begin{array}{ll}
\text { Yes } & \text { No Not Sure } \\
\text { If "NO", Why (Circle all that apply) - } & \text { Too High } \\
& \text { Too Many } \\
& \text { Too Cluttered } \\
& \text { Poor Design } \\
& \text { Unsafe placement } \\
& \text { Non-Informing }
\end{array}
$$


7. Is there enough landscaping:

$$
\text { Yes No Not Sure }
$$

8. Do you feel that all overhead electrical wiring should be placed underground:

$$
\text { Yes No Not Sure }
$$

9. In what areas do you believe corridor businesses and City government should concentrate on improving (Circle all that apply):

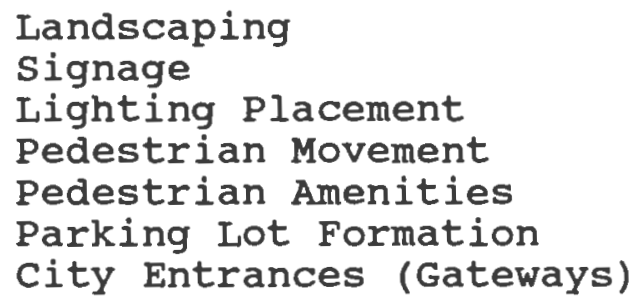

10. Do you feel that landscaped islands would be a good idea for 08 17-92 in orange city?

11. Do you have any additional comments to make: 
TABLE A. 9 ,

RESIDENT SURVEY RESULTS

\begin{tabular}{|c|c|c|}
\hline PARTICIPATING: & 120 & $68.18 \%$ \\
\hline NON-PARTICIPATING: & 56 & $31.82:$ \\
\hline TOTAL HOUSEHOLDS: & 176 & $100.00 \%$ \\
\hline SEX & TOTAL & PERCENTAGE OF TOTAL \\
\hline Male: & 46 & $38.33 \%$ \\
\hline Female: & 74 & $61.66 \%$ \\
\hline TOTAL: & 120 & $99.99 \%$ (Rounded off) \\
\hline AGE & TOTAL & PERCENTAGE OF TOTAL \\
\hline $0-10:$ & 0 & $0.00 \%$ \\
\hline $11-20:$ & 0 & $0.00 \%$ \\
\hline $21-30:$ & 7 & $5.83 \%$ \\
\hline $31-40:$ & 13 & $10.83 \%$ \\
\hline $41-50:$ & 10 & $8.33 \%$ \\
\hline $51-60:$ & 15 & $12.50 \%$ \\
\hline $61+$ Above: & 75 & $62.50 \%$ \\
\hline TOTAL: & 120 & $99.99 \%$ (Rounded Off) \\
\hline $\begin{array}{l}\text { 1. SAFE WHEN DRIVING } \\
\text { ON UB ROUTE 17-92 }\end{array}$ & TOTAL & PERCENTAGE OF TOTAL \\
\hline Yes: & 73 & $60.83 \%$ \\
\hline No: & 47 & $39.16 \%$ \\
\hline Not Sure: & 0 & $0.00 \%$ \\
\hline TOTAL: & 120 & $99.99 \%$ (Rounded Off) \\
\hline $\begin{array}{l}\text { 2. ARE AUTOMOBILE } \\
\text { SPEEDS SAFE } \\
\end{array}$ & TOTAL & PERCENTAGE OF TOTAL \\
\hline Yes: & 92 & $76.66 \%$ \\
\hline No: & 28 & $23.33 \%$ \\
\hline Not Sure: & 0 & $0.00 \%$ \\
\hline
\end{tabular}




\begin{tabular}{|c|c|c|}
\hline TOTAL: & 120 & $99.99 \%$ (Rounded off) \\
\hline $\begin{array}{l}\text { 3. I8 AREA PEDESTRIAN } \\
\text { SAFE }\end{array}$ & TOTAL & PERCENTAGE OF TOTAL \\
\hline Yes: & 54 & $45.00 \%$ \\
\hline No: & 55 & $45.83 \%$ \\
\hline Not sure: & 11 & $9.16 \%$ \\
\hline TOTAL: & 120 & $99.99 \%$ (Rounded off) \\
\hline $\begin{array}{l}\text { 4. ARE THERE ENOUGH } \\
\text { PEDEBTRIAN AMENITIES }\end{array}$ & TOTAL & PERCENTAGE OF TOTAL \\
\hline Yes: & 32 & $26.66 \%$ \\
\hline No: & 40 & $33.33 \%$ \\
\hline Not Sure: & 48 & 40.008 \\
\hline TOTAL: & 120 & $99.99 \%$ (Rounded off) \\
\hline $\begin{array}{l}\text { 5. I8 U8 ROUTE 17-92 } \\
\text { VIBUALLY PLEABING }\end{array}$ & TOTAL & PERCENTAGE OF TOTAL \\
\hline Yes: & 82 & $68.33 \%$ \\
\hline No: & 34 & $28.33 \%$ \\
\hline Not Sure: & 4 & $3.33 \%$ \\
\hline TOTAL: & 120 & 99.998 (Rounded off) \\
\hline $\begin{array}{l}\text { 6. I8 PRESENT SIGNAGE } \\
\text { VIBUALLY PLEABING } \\
\end{array}$ & TOTAL & PERCENTAGE OF TOTAL \\
\hline Yes: & 64 & $53.33 \%$ \\
\hline No: (Why): & 48 & $40.00 \%$ \\
\hline Too High - & $(15)$ & $(31.258)$ \\
\hline Too Many - & $(39)$ & $(81.25 \%)$ \\
\hline Too cluttered - & $(39)$ & $(81.25 \%)$ \\
\hline Poor Design - & (15) & $(31.258)$ \\
\hline $\begin{array}{l}\text { Unsafe } \\
\text { Placement - }\end{array}$ & $(02)$ & $(4 \cdot 168)$ \\
\hline Non-Informing - & $(08)$ & $(16.66 \%)$ \\
\hline Not sure: & 8 & $6.66 \%$ \\
\hline
\end{tabular}




\begin{tabular}{|c|c|c|}
\hline TOTAL: & 120 & $99.99 \%$ (Rounded off) \\
\hline $\begin{array}{l}\text { 7. IS THERE ENOUGH } \\
\text { LANDBCAPING }\end{array}$ & TOTAL & PERCENTAGE OF TOTAL \\
\hline Yes: & 49 & $40.83 \%$ \\
\hline No: & 65 & $54.16 \%$ \\
\hline Not Sure: & 6 & $5.00 \%$ \\
\hline TOTAL: & 120 & $99.99 \%$ (Rounded off) \\
\hline $\begin{array}{l}\text { 8. SHOULD WIRING BE } \\
\text { PLACED UNDERGROUND }\end{array}$ & TOTAL & PERCENTAGE OF TOTAL \\
\hline Yes: & 101 & $84.16 \%$ \\
\hline No: & 9 & $7.50 \%$ \\
\hline Not Sure: & 10 & $8.33 \%$ \\
\hline TOTAL: & 120 & $99.99 \%$ (Rounded off) \\
\hline $\begin{array}{l}\text { 9. WHAT AREAS SHOULD } \\
\text { ORANGE CITY AND LOCAL } \\
\text { BUSINESBES IMPROVE }\end{array}$ & TOTAL & PERCENTAGE OF TOTAL \\
\hline Landscaping: & $(66)$ & $(55.00 \%)$ \\
\hline Signage: & $(46)$ & $(38.338)$ \\
\hline Lighting Placement: & $(22)$ & $(18.338)$ \\
\hline Pedestrian Movement: & $(50)$ & $(41.66 \%)$ \\
\hline Pedestrian Amenities & (35) & $(29.168)$ \\
\hline Parking Areas: & $(20)$ & $(16.668)$ \\
\hline City Entrances: & (78) & $(65.00 \%)$ \\
\hline $\begin{array}{l}\text { 10. BHOULD LANDSCAPED } \\
\text { IBLANDS BE INSTITUTED } \\
\text { ALONG UB ROUTE 17-92 }\end{array}$ & TOTAL & PERCENTAGE OF TOTAL \\
\hline Yes: & 75 & $62.50 \%$ \\
\hline No: & 30 & $25.00 \%$ \\
\hline Not Sure: & 15 & $12.50 \%$ \\
\hline TOTAL: & 120 & $100.00 \%$ \\
\hline
\end{tabular}

(Source: Resident survey conducted by the author during the weeks of February 10, and March 2, 1994) 
TABLE A.10

\section{B USINES S S R V E Y}

James Kerr - Orange City Planning and zoning coordinator: 775-3333

(Please circle that answer which you feel best exemplifies your opinion on the condition in question)

Preliminary Information: Address:

1. Do you have problems with any of the following:
A. Traffic - Yes
No
Not Sure
B. Safety - Yes
No
Not Sure
C. Visibility -
Yes
No
Not Sure
D. Parking
Yes
No
Not Sure

2. Do you think any of the following are problems along us Route 17-92:
B. Traffic congestion - Yes If Yes: Where specifically -
A. Pedestrian safety - Yes
C. Automobile accidents - Yes No Not sure If Yes: Where specifically -
D. Traveling Speeds If Yes: Where specifically -
No Not Sure
No Not Sure No Not Sure

3. What do you think of the following:
A. Signage (Quantity) - Too Many Too Few Not Sure OK
B. Signage (Height)
C. Landscaping
- Too High OK
Not Sure
D. Lighting
- Inappropriate Appropriate NS
E. Pedestrian Amenities Too Much Too Little Not Sure OK
F. Improving city Entrances (Signage) - Yes
No
Not sure

4. should all overhead street wiring be placed underground: Yes No Not sure

5. Do you believe that us Route 17-92 is visually pleasing:

Yes No Not Sure

6. Do you believe that us Route $17-92$ is pedestrian friendly:

Yes No Not Sure 
7. Would you support a city-wide effort to upgrade Us Route 17-92:

Yes No Not sure

8. Do you have any additional comments to make: 
TABLE A. 11

BUBINE8B BURVEY REBULTS

\begin{tabular}{|c|c|c|}
\hline PARTICIPATING: & 105 & $58.66 \%$ \\
\hline NON-PARTICIPATING: & 74 & $41.34 \%$ \\
\hline TOTAL BUSINESBES: & 179 & $100.00 \%$ \\
\hline PARKING (LOCATION) & TOTAL & PERCENTAGE OF TOTAL \\
\hline Front: & 50 & $47.62 \%$ \\
\hline Rear: & 5 & $4.76 \%$ \\
\hline side: & 23 & $21.90 \%$ \\
\hline More than one side: & 27 & $25.71 \%$ \\
\hline None: & 0 & $0.00 \%$ \\
\hline TOTAL: & 105 & $99.99 \%$ (Rounded Off) \\
\hline 1. PERSONAL PROBLEMS & TOTAL & PERCENTAGE OF TOTAL \\
\hline \multicolumn{3}{|l|}{ Traffic - } \\
\hline Yes: & 69 & $65.71 \%$ \\
\hline No: & 32 & $30.47 \%$ \\
\hline Not Sure: & 1 & $0.95 \%$ \\
\hline Unanswered: & 3 & $2.86 \%$ \\
\hline TOTAL: & 105 & $99.99 \%$ (Rounded off) \\
\hline \multicolumn{3}{|l|}{ Safety - } \\
\hline Yes: & 45 & $42.86 \%$ \\
\hline No: & 49 & $46.66 \%$ \\
\hline Not Sure: & 4 & $3.81 \%$ \\
\hline Unanswered: & 7 & $6.66 \%$ \\
\hline TOTAI: & 105 & $99.99 \%$ (Rounded off) \\
\hline \multicolumn{3}{|l|}{ Visibility - } \\
\hline Yes: & 27 & $25.71 \%$ \\
\hline No: & 68 & $64.76 \%$ \\
\hline Not Sure: & 1 & $0.95 \%$ \\
\hline
\end{tabular}




\begin{tabular}{|c|c|c|}
\hline Unanswered: & 9 & $8.57 \%$ \\
\hline TOTAL: & 105 & 99.998 (Rounded off) \\
\hline \multicolumn{3}{|l|}{ Parking - } \\
\hline Yes: & 28 & $26.66 \%$ \\
\hline No: & 67 & $63.81 \%$ \\
\hline Not Sure: & 3 & $2.86 \%$ \\
\hline Unanswered: & 7 & $6.66 \%$ \\
\hline TOTAL: & 105 & $99.99 \%$ (Rounded off) \\
\hline $\begin{array}{l}\text { 2. PROBLEMS ALONG } \\
\text { OS ROUTE } 17-92 \\
\end{array}$ & TOTAL & PERCENTAGE OF TOTAL \\
\hline \multicolumn{3}{|l|}{ Pedestrian Safety - } \\
\hline Yes: & 49 & $46.66 \%$ \\
\hline No: & 44 & $41.90 \%$ \\
\hline Not Sure: & 10 & 9.528 \\
\hline Unanswered: & 2 & $1.91 \%$ \\
\hline TOTAL: & 105 & $99.99 \%$ (Rounded off) \\
\hline \multicolumn{3}{|l|}{ Traffic Congestion - } \\
\hline Yes: & 67 & $63.81 \%$ \\
\hline No: & 31 & $29.52 \%$ \\
\hline Not Sure: & 6 & $5.71 \%$ \\
\hline Unanswered: & 1 & 0.958 \\
\hline TOTAL: & 105 & 99.99\% (Rounded off) \\
\hline \multicolumn{3}{|l|}{ Accidents - } \\
\hline Yes: & 51 & $48.57 \%$ \\
\hline No: & 33 & $31.43 \%$ \\
\hline Not Sure: & 18 & $17.14 \%$ \\
\hline Unanswered: & 3 & $2.86 \%$ \\
\hline TOTAL: & 105 & $100.00 \%$ \\
\hline \multicolumn{3}{|l|}{ Travelling Speeds - } \\
\hline Yes: & 40 & $38.10 \%$ \\
\hline No: & 54 & $51.43 \%$ \\
\hline
\end{tabular}




\begin{tabular}{|c|c|c|}
\hline Not sure: & 7 & $6.66 \%$ \\
\hline Unanswered: & 4 & $3.81 \%$ \\
\hline TOTAL: & 105 & $100.00 \%$ \\
\hline $\begin{array}{l}\text { 3. Personal } \\
\text { Considerations }\end{array}$ & TOTAL & PERCENTAGE OF TOTAL \\
\hline \multicolumn{3}{|l|}{ Signage (Quantity) - } \\
\hline Too Many: & 13 & $12.38 \%$ \\
\hline Too Few: & 4 & $3.81 \%$ \\
\hline Acceptable: & 65 & $61.90 \%$ \\
\hline Not sure: & 12 & $11.43 \%$ \\
\hline Unanswered: & 11 & $10.47 \%$ \\
\hline TOTAL: & 105 & $99.99 \%$ (Rounded off) \\
\hline \multicolumn{3}{|l|}{ Signage (Height) - } \\
\hline Too High: & 8 & $7.62 \%$ \\
\hline Acceptable: & 77 & $73.33 \%$ \\
\hline Not Sure: & 10 & $9.52 \%$ \\
\hline Unanswered: & 10 & $9.52 \%$ \\
\hline TOTAL: & 105 & $99.99 \%$ (Rounded off) \\
\hline \multicolumn{3}{|l|}{ Landscaping - } \\
\hline Inappropriate: & 25 & $23.81 \%$ \\
\hline Appropriate: & 50 & $47.62 \%$ \\
\hline Not Sure: & 16 & $15.24 \%$ \\
\hline Unanswered: & 14 & $13.33 \%$ \\
\hline TOTAL: & 105 & $100.00 \%$ \\
\hline \multicolumn{3}{|l|}{ street Lighting - } \\
\hline Too Much: & 0 & $0.00 \%$ \\
\hline Too Little: & 23 & $21.90 \%$ \\
\hline Acceptable: & 55 & $52.38 \%$ \\
\hline Not Sure: & 10 & $9.52 \%$ \\
\hline Unanswered: & 17 & $16.20 \%$ \\
\hline TOTAL: & 105 & $100.00 \%$ \\
\hline
\end{tabular}




\begin{tabular}{|c|c|c|}
\hline \multicolumn{3}{|l|}{ Pedestrian Amenities - } \\
\hline Too Many: & 1 & $0.95 \%$ \\
\hline Too Few: & 32 & 30.478 \\
\hline Acceptable: & 38 & $36.20 \%$ \\
\hline Not Sure: & 18 & $17.14 \%$ \\
\hline Unanswered: & 16 & $15.24 \%$ \\
\hline TOTAL: & 105 & $100.00 \%$ \\
\hline \multicolumn{3}{|l|}{$\begin{array}{l}\text { Improve City Entrances } \\
\text { (Signage) - }\end{array}$} \\
\hline Yes: & 43 & $40.95 \%$ \\
\hline No: & 26 & $24.76 \%$ \\
\hline Not Sure: & 27 & $25.71 \%$ \\
\hline Unanswered: & 9 & $8.57 \%$ \\
\hline TOTAL: & 105 & 99.99\% (Rounded off) \\
\hline $\begin{array}{l}\text { 4. BHOULD WIRING BE } \\
\text { PLACED UNDERGROUND }\end{array}$ & TOTAL & PERCENTAGE OF TOTAL \\
\hline Yes: & 49 & $46.66 \%$ \\
\hline No: & 29 & 27.628 \\
\hline Not Sure: & 27 & 25.718 \\
\hline Unanswered: & 0 & $0.00 \%$ \\
\hline TOTAL: & 105 & 99.998 (Rounded off) \\
\hline $\begin{array}{l}\text { 5. I8 U8 ROUTE 17-92 } \\
\text { VIBUALLY PLEABING }\end{array}$ & TOTAL & PERCENTAGE OF TOTAL \\
\hline Yes: & 44 & $41.90 \%$ \\
\hline No: & 47 & 44.768 \\
\hline Not Sure: & 14 & $13.33 \%$ \\
\hline Unanswered: & 0 & $0.00 \%$ \\
\hline TOTAL: & 105 & 99.998 (Rounded off) \\
\hline & & \\
\hline
\end{tabular}




\begin{tabular}{|c|c|c|}
\hline $\begin{array}{l}\text { 6. IS US ROUTE 17-92 } \\
\text { PEDESTRIAN FRIENDLY }\end{array}$ & TOTAL & PERCENTAGE OF TOTAL \\
\hline Yes: & 31 & $29.52 \%$ \\
\hline No: & 60 & $57.14 \%$ \\
\hline Not Sure: & 14 & $13.33 \%$ \\
\hline Unanswered: & 0 & $0.00 \%$ \\
\hline TOTAL: & 105 & 99.998 (Rounded off) \\
\hline $\begin{array}{l}\text { 7. SUPPORT CITY-WIDE } \\
\text { EFFORT TO UPGRADE } \\
\text { UB ROUTE 17-92 }\end{array}$ & TOTAL & PERCENTAGE OF TOTAL \\
\hline Yes: & 56 & $53.33 \%$ \\
\hline No: & 18 & $17.14 \%$ \\
\hline Not Sure: & 31 & $29.52 \%$ \\
\hline Unanswered: & 0 & $0.00 \%$ \\
\hline TOTAL: & 105 & 99.998 (Rounded Off) \\
\hline
\end{tabular}

(Source: Business survey conducted by the author during the weeks of February 21, and March 2, 1994) 
R E F E R E N C E S 
1990 Census of Population and Housing. Summary Tape File 3A. Deland, Florida: Stetson University, 1990.

Bishop, Kirk R. "Designing Urban Corridors." Planning Advisory Service Report, no. 418 (1990).

Boylan, Robert J., and Neil S. Kenig. "An Approach to Determining Parking Demand." Planning Advisory Service Report, no. 270 (1971).

Brevard, Caroline Mays. A History of Florida. New York. N.Y.: American Book Company, 1919.

Browne, Carolyn. "The Mechanisms of Sign Control." Planning Advisory Service Report, no. 354 (1980).

Bureau of Economic and Business Research, College of Business Administration. "Florida Estimates of Population April 1, 1992." Gainesville, Florida: University of Florida, 1993. Photocopied.

Cardoso, Nathaniel. Local Amateur Graphic Artist. Providence, Rhode Island. May 1994.

Corwin, Margaret A. "Parking Lot Landscaping." Planning Advisory Service Report, no. 335 (1978).

Covington, Jim. "Visual Enhancement of a Commercial Corridor: West Memphis, Arkansas." Urban Design and Preservation Quarterly 13, no. 4 (Winter 1990): 14-16.

Cuyahoga County Planning Commission. Brookpark Road Corridor study. Cleveland, Ohio: Cuyahoga County Planning Commission, 1988 .

Dreggors, Bill. Interview by author, 28 February 1994, Deland, Florida. Oral. West Volusia Historical Society, Deland, Florida.

Eugene Department of Planning. City of Eugene: Entrance Beautification Study. Eugene, Oregon: City of Eugene Planning Department, 1984.

Fitzgerald, T. E. Volusia County Past and Present. Daytona Beach: Florida: The Observer Press, 1937.

Florida Department of Transportation. Volusia County Roadway Report. Deland, Florida: Florida Department of Transportation, 1993. 
Glassford, Peggy. "Appearance Codes for Small Communities." Planning Advisory Service Report, no. 379 (1983) .

Gold, Pleasant Daniel. History of Volusia county, Florida. DeLand, Florida: The E.O. Painter Printing Co., 1927.

Goose, Carol. Interview by author, 21 February 1994, Deltona, Florida. Oral. Deltona, Florida.

Gould Evans Associates, P.C. Independence Avenue Corridor Plan. Kansas City, Missouri: Kansas City Planning Department, 1993.

Greater Chamber of Commerce. Guide to orange City, Florida. Orange City, Florida: official Publication of the Greater Orange City Area Chamber of Commerce, 1992.

Harrison, Sandy. "Adopt-a-Highway program a success." Daily News - Sacramento Bureau, 2 November 1992, (Page No. Unknown) .

Hebel, Ianthe B., ed. Centennial History of Volusia County, Florida 1854 - 1954. Daytona Beach, Florida: College Publishing Co., 1955.

Hinshaw, Mark L. Design Objectives Plan: Entryway Corridors. Bozeman, Montana, 1991.

Houten Therese, and Harry P. Hatry. "How to Conduct a Citizen Survey." Planning Advisory Service Report, no. 404 (1987).

Howard, Needles, Tammen and Bergendoff. Grand/Main Corridor study summary Report. Kansas City, Missouri, 1987.

Kansas City Development Department: Planning and Urban Design. Ward Parkway Corridor Study. Kansas City, Missouri: Kansas City Planning and Urban Design Department, 1990.

Kenosha Department of City Development. Corridor Land Use Plan. Kenosha, Wisconsin: Kenosha Department of City Development, 1991.

Kerr, James, orange city planning and zoning coordinator. Interview by author, 25 october 1991, orange City, Florida. Tape recording. Orange city Town Hall, Orange City, Florida.

Kerr, James, orange City planning and zoning coordinator. Interview by author, 7 February 1994, Orange city, Florida. Oral. Orange City Town Hall, orange City, Florida. 
Kriken, John L., and Irene Perlis Torrey. "Developing Urban Design Mechanisms." Planning Advisory Service Report, no. 296 (1973).

Kubat, Charles A. "Enlisting Highway Corridors to Knit-Not Split-Communities." Urban Land (16-20 July 1991).

Linkovich, Bill. "Crash Detail Reports from 1987 - 1992." Deland, Florida: Department of Transportation, 1987-1992. Computer Printout.

Linkovich, Bill. "Volusia County Roadway Report." Deland, Florida: Department of Transportation, 1993. Computer Printout.

Lundberg, Barry D., and Charles W. Lustig. "Demand Responsive Transit Service: A New Transportation Tool." Planning Advisory Service, no. 286 (1972): 1.

Manatee county Planning, Permitting \& Inspections. U.S. Highway 41 Corridor study: Inventory and Analysis. Bradenton, Florida: Manatee County Planning, Permitting \& Inspections Department, 1992.

Martz, Wendelyn A., and Marya Morris. "Preparing a Landscaping Ordinance." Planning Advisory Service Report, no. 431 (1990).

McAllister, Antoinette. "Zoning for Fast-Food and Drive-In Restaurants." Planning Advisory Service Report, no. 320 (1976).

Moritz, Milton, orange city director of public works. Interview by author, 10 February 1994, Orange City, Florida. Oral. Orange City Town Hall, orange City, Florida.

Moritz, Milton, orange city director of public works. Interview by author, 20 April 1994, Orange City, Florida. Telephone.

Mosher-Adams, Inc. Map of Orange City, Florida. 1993.

Quintana, Craig. "Spinning wheels on Beltline." The Orlando Sentinel, 19 January 1992, K-1.

Reynolds, Smith, and Hills, Inc. Orange City, Florida Comprehensive Plan. Jacksonville, Florida: Reynolds, Smith and Hills. 1992.

Reynolds, Smith, and Hills, Inc. Orange City, Florida zoning Ordinance. Jacksonville, Florida: Reynolds, Smith and Hills. 1991. 
Scott, Robert L. "The Effect of Nonconforming Land-Use Amortization." Planning Advisory Service Report, no. 280 (1972).

Staff. "Black Bear Trail." Daytona Beach News Journal: DeLand Bureau, (Date is unknown, however, a copy is filed with the Volusia County Library Center, City Island, Daytona Beach, Florida)

Staff. "Council Unlikely to Vote on Mass Transit." The News Journal: West Volusia Bureau, 18 December 1991, 2(B).

Stefanski, Cindy. "New Highways Need Access Restrictions." The Volusian, 21 July 1991, Section: Viewpoint.

Sutro, Suzanne. "Reinventing the Village." Planning Advisory Service Report, no. 430 (1990).

Tebeau, Charlton W. A History of Florida. Coral Gables, Florida: University of Miami Press, 1971.

Village Improvement Association. Our Story of Orange City, Florida. Deland, Florida: Carter Printing Co., 1975.

Volusia County Business Development Corporation. 1990 - 1991 Volusia County Data Profile. Daytona Beach, Florida: volusia County Business Development Corp. 1992.

Whitney, Bailey, Cox and Magnani. Bond street Corridor Redevelopment strategy \& Streetscape Improvement Plan. Bel Air, Maryland: Bel Air Planning Department, 1991.

Wittgenfeld, Dallas, commercial pilot, travel agent and local amateur historian on orange City. Interview by author, 10 october 1991, orange City, Florida. Tape recording. $\mathrm{X}$-Pert Travel Agency, orange City, Florida. 